UNIVERSIDADE DE SÃO PAULO

ESCOLA DE ENGENHARIA DE SÃO CARLOS

DEPARTAMENTO DE ENGENHARIA DE ESTRUTURAS

GIOVANNI PAIS PELLIZZER

SOBRE A MODELAGEM NUMÉRICA DA DIFUSÃO DE

CLORETOS NO CONCRETO: UMA ABORDAGEM PELO

MÉTODO DOS ELEMENTOS DE CONTORNO COM

APLICAÇÃO DE MODELOS DE CONFIABILIDADE E

OTIMIZAÇÃO

VERSÃO CORRIGIDA

A versão original encontra-se na Escola de Engenharia de São Carlos 



\title{
SOBRE A MODELAGEM NUMÉRICA DA DIFUSÃO DE CLORETOS NO CONCRETO: UMA ABORDAGEM PELO MÉTODO DOS ELEMENTOS DE CONTORNO COM APLICAÇÃO DE MODELOS DE CONFIABILIDADE E OTIMIZAÇÃO
}

\author{
VERSÃO CORRIGIDA
}

A versão original encontra-se na Escola de Engenharia de São Carlos

\begin{abstract}
Tese apresentada ao Departamento de Engenharia de Estruturas da EESC-USP como parte dos requisitos necessários a obtenção do título de Doutor em Engenharia de Estruturas.
\end{abstract}

Programa: Engenharia Civil (Engenharia de Estruturas)

Área de concentração: Estruturas

Orientador: Prof. Dr. Edson Denner Leonel 
AUTORIZO A REPRODUÇÃO TOTAL OU PARCIAL DESTE TRABALHO, POR QUALQUER MEIO CONVENCIONAL OU ELETRONNICO, PARA FINS DE ESTUDO E PESQUISA, DESDE QUE CITADA A FONTE.

Ficha catalográfica elaborada pela Biblioteca Prof. Dr. Sérgio Rodrigues Fontes da EESC/USP com os dados inseridos pelo(a) autor(a).

Pais Pellizzer, Giovanni

P391s Sobre a modelagem numérica da difusão de cloretos no concreto: uma abordagem pelo método dos elementos de contorno com aplicação de modelos de confiabilidade e otimização / Giovanni Pais Pellizzer; orientador Edson Denner Leonel. São Carlos, 2019.

Tese (Doutorado) - Programa de Pós-Graduação em Engenharia Civil(Engenharia de Estruturas) e Área de Concentração em Estruturas -- Escola de Engenharia de São Carlos da Universidade de São Paulo, 2019.

1. corrosão. 2. cloretos. 3. difusão. 4. concreto armado. 5. método dos elementos de contorno. 6 . confiabilidade. 7. otimização. I. Título.

Eduardo Graziosi Silva - CRB - 8/8907 


\section{FOLHA DE JULGAMENTO}

\section{Candidato: Bacharel GIOVANNI PAIS PELLIZZER.}

Título da tese: "Sobre a modelagem da difusão de cloretos no concreto: uma abordagem pelo método dos elementos de contorno $\mathrm{cm}$ aplicação de modelos de confiabilidade e otimização".

Data da defesa: 18/04/2019.

\section{Comissão Julgadora:}

Resultado:

Prof. Associado Edson Denner Leonel

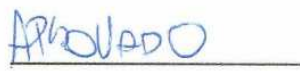

(Orientador)

(Escola de Engenharia de São Carlos/EESC)

Prof. Dr. Rogério Carrazedo

AROVADO

(Escola de Engenharia de São Carlos/EESC)

Prof. Dr. Caio Gorla Nogueira

Aprovado

(Universidade Estadual Paulista "Júlio de Mesquita Filho"/UNESP- Bauru)

Profa. Dra. Edna Possan

AROUADO

(Universidade Federal da Integração Latino-Americana/UNILA)

Profa. Dra. Gabriela Rezende Fernandes

(Universidade Federal de Góias/UFG)

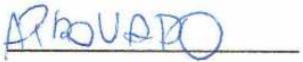

Coordenador do Programa de Pós-Graduação em Engenharia Civil (Engenharia de Estruturas):

Prof. Assoc. Vladimir Guilherme Haach

Presidente da Comissão de Pós-Graduação:

Prof. Titular Murilo Araujo Romero 

A Deus, princípio e fim de todas as coisas.

A minha família e em especial aos meus pais, Gabriella e Lino, por todo o amor incondicional doado, por procurarem me transmitir valores e por sempre me incentivarem nos estudos e outros projetos de vida. Mãe, pai, para mim vocês são preciosos exemplos de dedicação e altruísmo sincero.

A Sonia, amada companheira de caminhada pelas estradas da vida. Longe ou perto, todo o amor, cumplicidade, paciência e apoio a mim dedicados foram essenciais para eu chegar até aqui. Ti ringrazio di cuore per tutto quello che sei, per quello che mi doni senza neanche renderti conto e per sempre aver creduto in me! Io ti amo!

Ao meu orientador, professor Edson Denner Leonel, que em sua tranquilidade como pessoa e em seu primor como profissional procuro me espelhar. Agradeço pela constante disponibilidade, paciência, atenção e confiança depositada em mim.

Aos amigos antigos e aos que fiz ao longo dessa caminhada na pós-graduação. Obrigado por cada momento compartilhado e por me fazerem lembrar constantemente de levar a vida com leveza e alegria. Vocês enriqueceram a minha existência e consolidaram em mim a significância da palavra "amizade".

A todos os professores e mestres que cruzaram o meu caminho. Agradeço por fomentar em mim o desejo de me aperfeiçoar e buscar sabedoria.

A todos os funcionários do departamento de engenharia de estruturas da EESC/USP, pelo incessante auxílio e solicitude despendidos.

A CAPES pelo suporte financeiro para o desenvolvimento desta pesquisa, a UFMS pelo período de afastamento concedido para conclusão do doutorado e a todos os contribuintes brasileiros, muitos dos quais, infelizmente, não tiveram as possibilidades que tive. Sinto-me privilegiado e imensamente grato. 

"But the real way to get happiness is by giving out happiness to other people. Try and leave this world a little better than you found it, and when your turn comes to die you can die happy in feeling that at any rate you have not wasted your time but have done your best."

R.S.S. Baden-Powell 

PELLIZZER, G.P. Sobre a modelagem numérica da difusão de cloretos no concreto: uma abordagem pelo método dos elementos de contorno com aplicação de modelos de confiabilidade e otimização. Tese (Doutorado em Engenharia de Estruturas), Escola de Engenharia de São Carlos, Universidade de São Paulo, 2019.

O principal mecanismo de transporte de íons cloreto pelos microporos do concreto é a difusão. Em um dado instante do processo difusivo, quando a concentração de cloretos na interface concreto/armadura atinge um valor limite, ocorre a despassivação das armaduras. É neste instante que se encerra a etapa de iniciação e onde se inicia a etapa de propagação da corrosão. Considerando-se que após o início da etapa de propagação a segurança estrutural decai rapidamente, devido aos diversos mecanismos deletérios ocasionados pela corrosão, é fundamental prever adequadamente quando se dará o seu início. Existem disponíveis na literatura diversos métodos para a análise da etapa de iniciação. Contudo, poucos utilizam o método dos elementos de contorno (MEC) para este fim. Além disso, devido à elevada aleatoriedade presente neste fenômeno, uma abordagem sob um ponto de vista probabilístico apresenta grande potencial para um tratamento adequado do problema. Por fim, objetivando encontrar configurações de projeto propícias a manutenção de um dado nível de segurança mínimo durante toda a vida útil estrutural, podem ser empregados modelos de otimização sob incertezas. Assim, o presente trabalho tem por objetivo apresentar uma formulação baseada no MEC que torne possível a análise determinística, probabilística e de otimização da etapa de iniciação para problemas de difusão no concreto em regime transiente. É descrita a formulação do problema e o esquema de resolução do mesmo, implementados computacionalmente. Exemplos de aplicação são apresentados validando e mostrando a eficiência das formulações adotadas. Destacam-se as limitações de soluções analíticas, as potencialidades da solução numérica e a grande influência que as condições de contorno exercem sobre o fenômeno.

Palavras-Chave: corrosão; cloretos; difusão; concreto armado; método dos elementos de contorno; confiabilidade; otimização. 
PELLIZZER, G.P. On the numerical modeling of diffusion of chlorides in concrete: an approach by the boundary element method with the application of reliability and optimization models. Thesis (Doctoral degree in Structural Engineering), São Carlos School of Engineering, University of São Paulo, 2019.

Diffusion is the main transport mechanism of chloride ions through the micropores of concrete. At a given moment of the diffusive process, when the chloride concentration at the concrete/reinforcement interface reaches a threshold level, reinforcement depassivation occurs. At this point, the initiation stage ends and the corrosion propagation stage begins. Considering that after the start of the propagation stage the structural safety decays rapidly, due to the various deleterious mechanisms caused by corrosion, it is essential to adequately predict when it will start. Several methods for the analysis of the initiation stage are available in the literature. However, few of then use the boundary element method (BEM) for this purpose. Moreover, due to the high randomness present in this phenomenon, a probabilistic approach presents great potential for an adequate treatment of the problem. Finally, in order to find project configurations propitious to maintaining a given minimum level of safety during the entire useful structural life, optimization models under uncertainties can be used. Thus, the present work aims to present a formulation based on the BEM that makes possible the deterministic, probabilistic and optimization analysis of the initiation stage for unsteady state diffusion problems in concrete. The problem formulation and the implementation resolution scheme are described. Application examples are presented validating and showing the efficiency of the formulations adopted. The limitations of analytical solutions, the potentialities of the numerical solution and the great influence that the boundary conditions weigh on the phenomenon are highlighted.

Keywords: corrosion; chlorides; diffusion; reinforced concrete; boundary element method; reliability; optimization. 


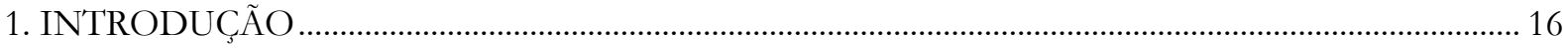

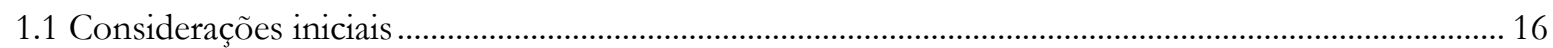

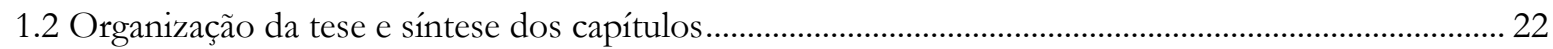

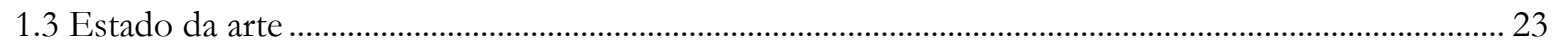

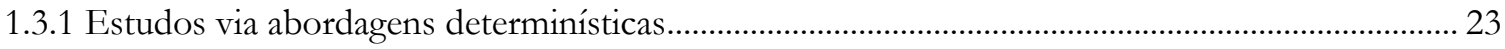

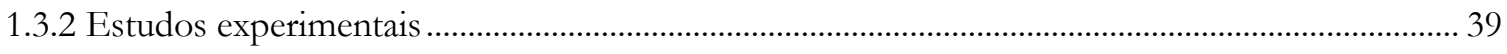

1.3.3 Estudos utilizando o método dos elementos de contorno .................................................................. 57

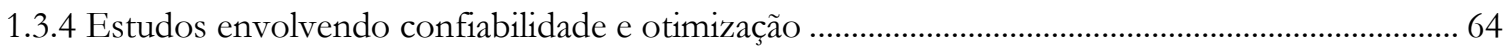

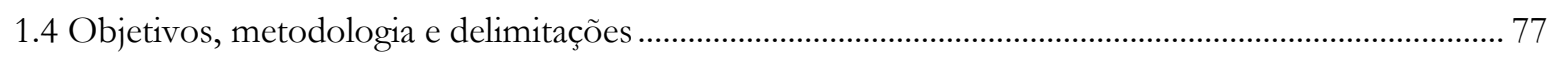

2. MÉTODO DOS ELEMENTOS DE CONTORNO APLICADO A PROBLEMAS DE DIFUSÃO79

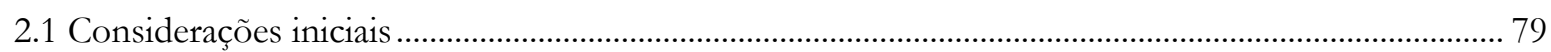

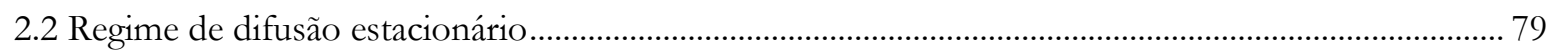

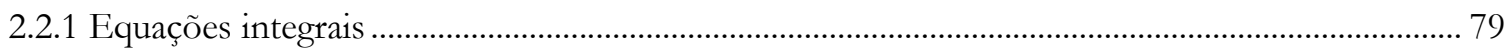

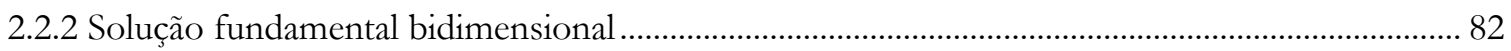

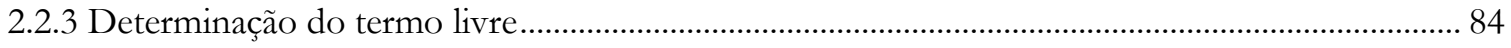

2.2.4 Introdução das funções de aproximação …………………………………………………………...... 89

2.2.4.1 Aproximações no contorno ………………………………………………………………..... 89

2.2.4.2 Aproximação e integração numérica da equação integral.......................................................... 91

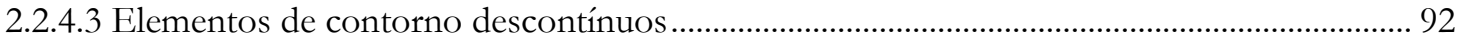

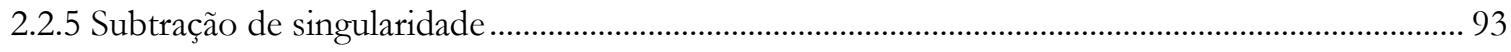

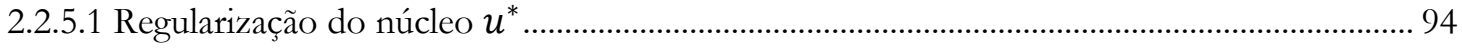

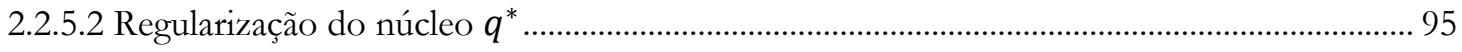

2.2.6 Determinação das grandezas internas ........................................................................................... 97

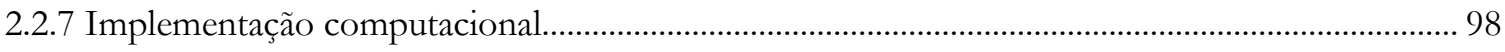

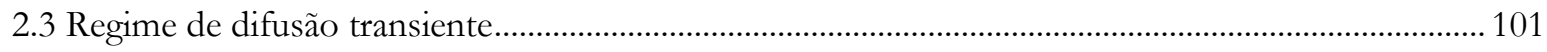

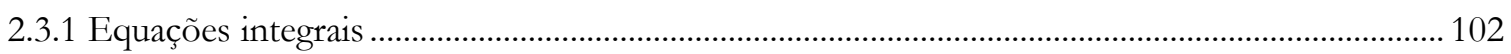

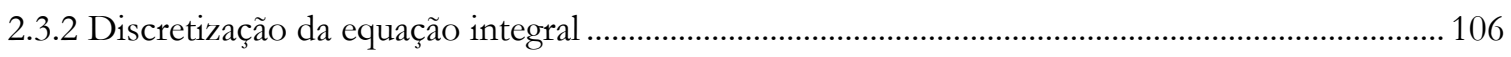

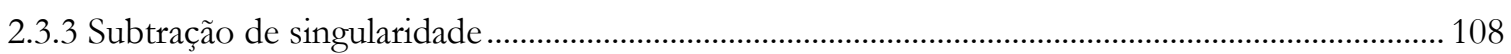

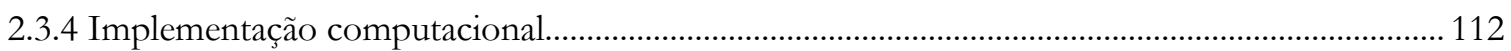

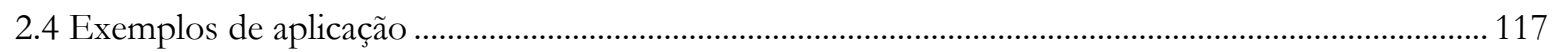

2.4.1 Exemplo 1 - Regime estacionário: domínio quadrado...................................................................... 117

2.4.2 Exemplo 2 - Regime estacionário: domínio circular ...................................................................... 119

2.4.3 Exemplo 3 - Regime transiente: domínio quadrado com fluxo unidimensional ......................... 121

2.4.4 Exemplo 4 - Regime transiente: domínio quadrado com fluxo bidimensional ............................ 124 
2.4.5 Exemplo 5 - Regime transiente: domínio circular.

2.4.6 Exemplo 6 - Regime transiente: comparativo MEC e $2^{\text {a }}$ lei de Fick em um domínio retangular

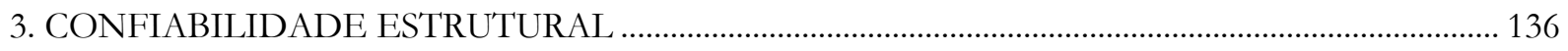

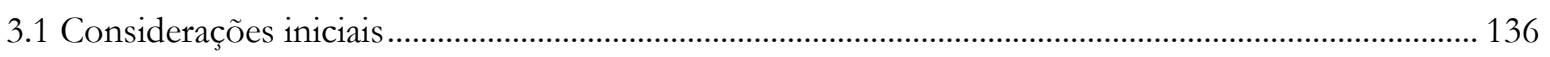

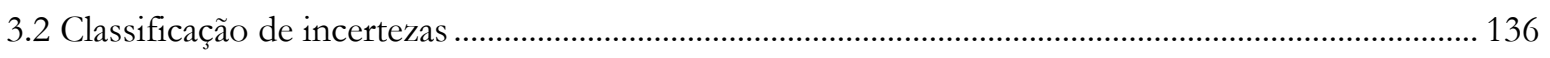

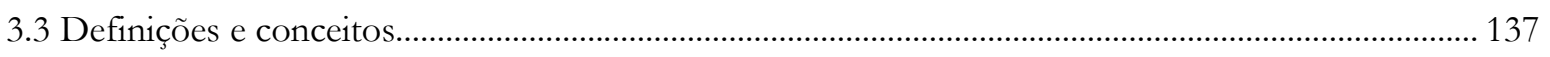

3.3.1 Experimento, evento e espaço amostral ............................................................................... 137

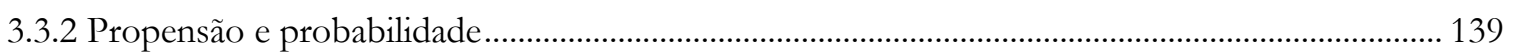

3.3.3 Variável aleatória e distribuições de probabilidade .................................................................... 139

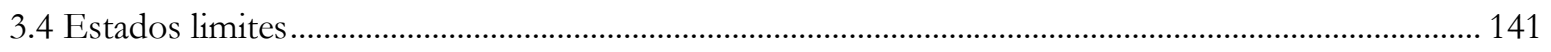

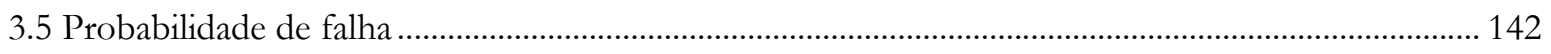

3.6 O problema elementar da confiabilidade estrutural e o índice de confiabilidade............................ 143

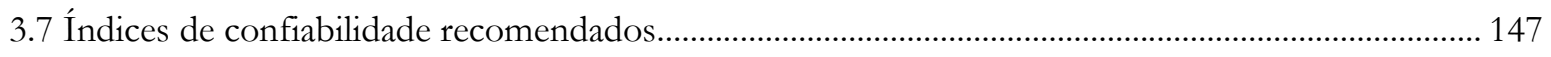

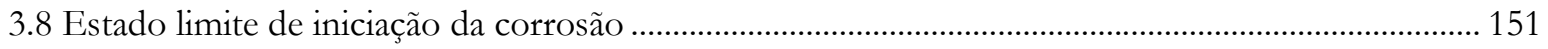

3.9 Métodos para estimativa da probabilidade de falha........................................................................ 153

3.10 Método de simulação de Monte Carlo ................................................................................................. 155

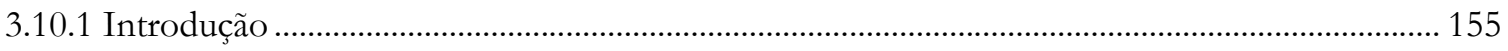

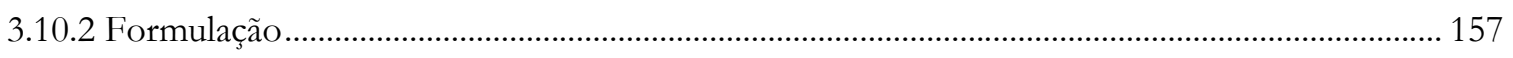

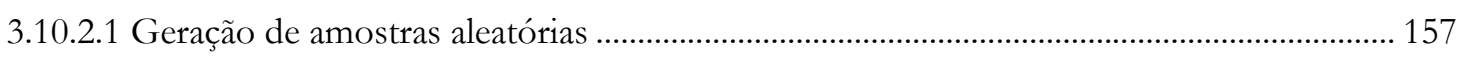

3.10.2.2 Avaliação da ocorrência da falha ................................................................................... 158

3.10.2.3 Estimativa da probabilidade de falha e sua variância ......................................................... 159

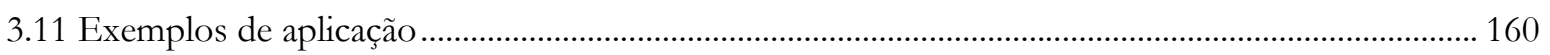

3.11.1 Exemplo 1: comparativo MEC e 2a lei de Fick em um domínio retangular via MSMC.......... 160

3.11.2 Exemplo 2: domínio em formato de T e curvas de isoprobabilidade de despassivação .......... 165

4. OTIMIZAÇÃO ESTRUTURAL BASEADA EM CONFIABILIDADE ........................................... 172

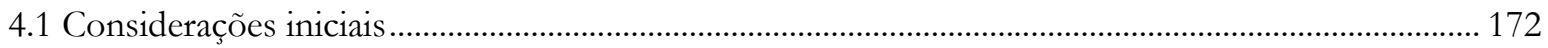

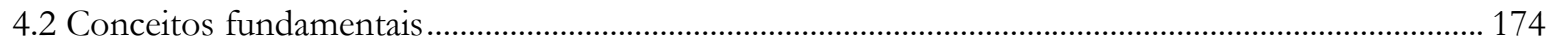

4.2.1 Formulação matemática geral para problemas de otimização estrutural................................... 174

4.2.2 Ponto viável, domínio viável, restrições ativas e inativas .......................................................... 175

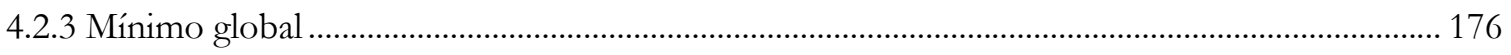

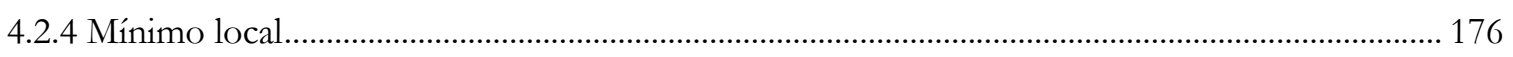

4.2.5 Condições necessárias e suficientes de otimalidade ................................................................... 176

4.2.6 Condições necessárias e suficientes para mínimos locais em problemas sem restrições ............ 177

4.2.7 Condições necessárias e suficientes para mínimos locais em problemas com restrições ........... 178

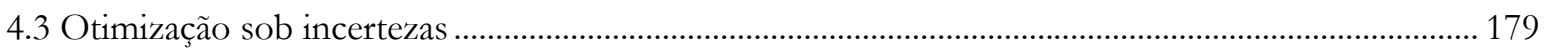

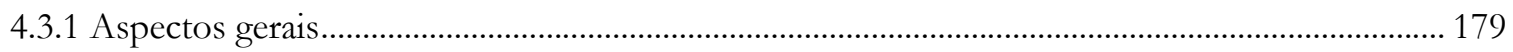


4.3.2 Otimização determinística

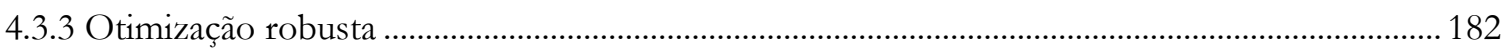

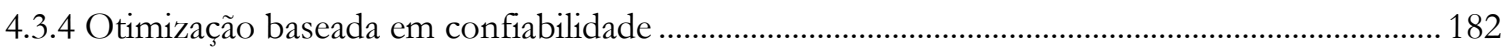

4.3.5 Otimização do custo do ciclo de vida e do risco ......................................................................... 183

4.3.6 Potencialidades e limitações das diferentes abordagens de otimização ....................................... 184

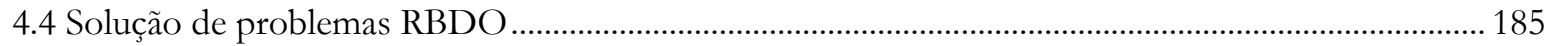

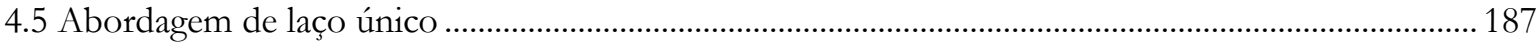

4.6 Método de simulação ponderada em problemas RBDO ..................................................................... 189

4.6.1 Ponderação de amostras no cálculo da probabilidade de falha .................................................. 189

4.6.2 Acoplamento do WASM em problemas RBDO ...................................................................... 190

4.6.3 Vantagens e desvantagens do método........................................................................................ 193

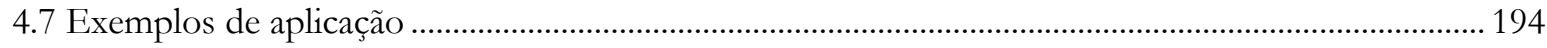

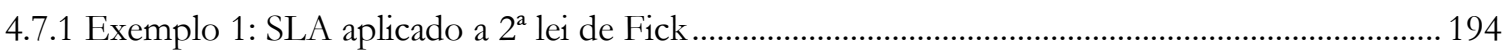

4.7.2 Exemplo 2: WASM/RBDO aplicados ao MEC em um domínio quadrado ............................... 198

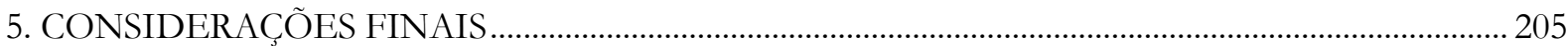

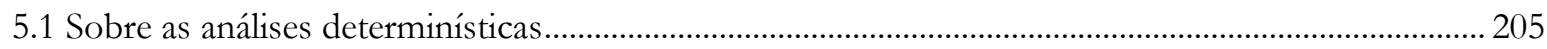

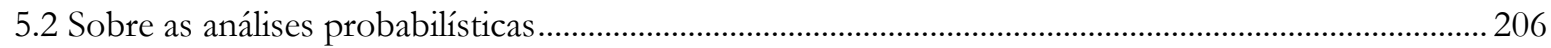

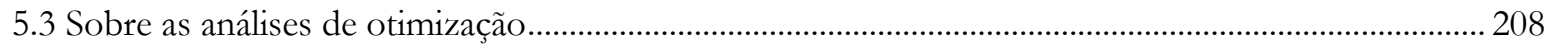

5.4 Sugestões para trabalhos futuros .................................................................................................... 209

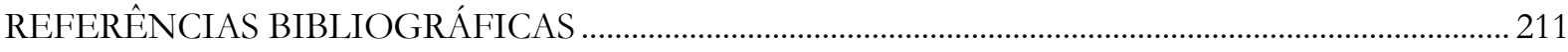

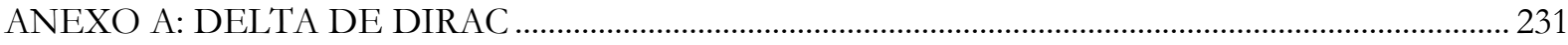

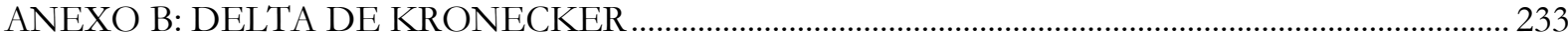




\section{INTRODUÇÃO}

\subsection{Considerações iniciais}

Atualmente a vida útil e durabilidade estrutural têm sido objetos de diversos estudos e investigações na área da engenharia. Por vida útil entende-se o período de tempo no qual o desempenho estrutural frente a requisitos de serviço, segurança e robustez se mantem satisfatório, conforme previsto em projeto, sem ações imprevistas de manutenção ou reparo. Já a durabilidade pode ser definida como a capacidade de uma estrutura em resistir aos efeitos de processos de deterioração aos quais a mesma estará submetida ao longo de sua vida útil. O conhecimento/previsão do comportamento estrutural ao longo de toda a vida útil é altamente desejável, sendo possível assim garantir uma adequada segurança e otimizar os diversos custos envolvidos.

Alterações na durabilidade e vida útil claramente podem estar ocorrendo quando uma estrutura apresentar manifestações patológicas que modifiquem sua integridade. Contudo, em alguns casos, pode acontecer que a estrutura não apresente sinais visíveis de manifestações patológicas e mesmo assim estar sofrendo processos de degradação. As ações ambientais estão entre os principais fatores originadores de manifestações patológicas.

A maior parte das estruturas, ainda que tenham sido projetadas e executadas o mais próximo possível da perfeição, apresentarão, inevitavelmente, manifestações patológicas com o decorrer do tempo. Assim sendo, as condições ambientais presentes no local de inserção dessas estruturas e os efeitos decorrentes do tempo devem ser incluídos nas etapas de projeto, monitoramento e manutenção.

Especificamente nas estruturas de concreto armado, os principais mecanismos de deterioração são: expansão por sulfatos, reação álcali-agregado, lixiviação e despassivação das armaduras por carbonatação ou ação de íons cloretos (ABNT NBR 6118, 2014). Contudo, é largamente reconhecido que o ingresso de íons cloreto e a sucessiva corrosão das armaduras é o principal mecanismo de deterioração da capacidade resistente dos elementos estruturais de concreto armado (WHITING, 1981; PAGE e TREADAWAY, 1982; PAGE e LAMBERT, 1987; CEB, 1992; ANDRADE, 1993; BAMFORTH e CHAPMAN-ANDREWS, 1994; GONZALEZ et al., 1995; CASCUDO, 1997; KURTIS e MEHTA, 1997; VAL e MELCHERS, 1997; GLASSER et al., 1999; BERTOLINI et al., 2000; CLIMENT et al., 2000; MARTÍNPÉREZ et al., 2000; VAL e STEWART, 2003; BOHNI, 2005; MEHTA e MONTEIRO, 2005; 
BROOMFIELD, 2007; MEIRA et al., 2007; APOSTOLOPOULOS e PAPADAKIS, 2008; SUO e STEWART, 2009; BAROGHEL-BOUNY et al., 2010; ZHANG et al., 2010; BASTIDASARTEAGA et al., 2011).

Em um contexto etimológico, a palavra "corrosão" é originária da palavra do latim corrosionem, substantivo de ação do particípio passado de corrodere, que significa "roer em pedaços" ou "desgastar-se". Em termos práticos a corrosão é definida como a deterioração de um material, normalmente metálico, por ação química ou eletroquímica do meio ambiente associada ou não a esforços mecânicos. A corrosão é também muito preocupante devido à grande quantidade de casos reportados de estruturas afetadas e acidentes envolvendo esse problema patológico.

Em maio de 2000, apenas cinco anos após a sua construção, uma passarela de concreto protendido que fazia a ligação entre a pista de corrida e o estacionamento da Charlotte Motor Speedway na Carolina do Norte, Estados Unidos, colapsou. Centenas de pessoas estavam passando pela estrutura após assistir a uma corrida no circuito quando se ouviram dois fortes estalos. Um dos vãos com 25 metros de extensão cedeu e as pessoas caíram de pouco mais de 5 metros de altura. Felizmente não ouve nenhum óbito, porém 107 pessoas ficaram feridas e 13 ficaram gravemente feridas. Os investigadores constataram que a falha estrutural ocorreu devido a corrosão dos 11 cabos de aço protendidos. A corrosão foi causada pelo cloreto de cálcio (altamente corrosivo) que era um dos componentes do concreto em torno dos cabos de aço. Foi identificado que o concreto possuía uma concentração 40 vezes maior dessa substância do que a quantidade aceitável, na tentativa de acelerar o processo de pega. Cinquenta ações judiciais foram feitas contra a construtora e a administradora do circuito, somando milhões de dólares em indenizações (NACE ${ }^{a}$, s.d.).

A ponte estadunidense Leo Frigo, inaugurada em 1980 e sendo uma importante ligação comercial entre os estados de Michigan e Wisconsin, teve parte de seu tabuleiro rebaixado em mais de 60 centímetros em uma tarde de setembro de 2013. A causa foi atribuída a corrosão dos suportes metálicos no subsolo que acabaram encurvando sob o peso da estrutura. Ninguém ficou ferido e a ponte foi imediatamente fechada. Um ano antes do ocorrido, na última inspeção realizada, a ponte recebeu altas notas de solidez estrutural. $O$ gerente de projetos do departamento de transportes alegou que os inspetores não descobriram as deficiências porque o teste de corrosão não faz parte de uma inspeção normal da ponte. A ponte ficou fechada três meses e meio para reparação a um custo de 20 milhões de dólares. Outros custos envolvidos devido ao fechamento da ponte foram estimados em torno de 14,5 milhões de dólares (NACE ${ }^{\mathrm{b}}$, s.d.). 
Outro caso refere-se ao colapso de uma ponte perto de Milão, na Itália, em outubro de 2016. A falha ocorreu quando um caminhão com uma carga elevada, mas dentro do tolerável para aquele tipo de estrutura, passou sobre a viga central da ponte que acabou rompendo de maneira frágil. Um engenheiro especialista alegou que uma possível causa do colapso possa ter sido a corrosão das armaduras de aço devido aos sais de degelo que foram utilizados na estrutura desde a sua construção, por volta dos anos 60 ou 70. Outra causa apontada foi o elevado grau de fissuração da estrutura, a passagem constante de veículos com cargas elevadas e a manutenção inadequada da ponte. O desastre ocasionou a morte de uma pessoa e feriu outras quatro (FOTIA, 2016; GEROSA, 2017).

No Brasil um caso envolvendo uma estrutura corroída é o do Elevado do Joá. Esta estrutura em concreto armado sustenta os 1100 metros de pista nos dois sentidos, suspensa 35 metros acima do nível do mar. Está localizado na zona sul do Rio de Janeiro, tendo sido inaugurado em 1971 e posteriormente foi duplicado em 2016 na preparação da cidade para os Jogos Olímpicos de 2016, como forma de expandir a capacidade de transporte à região do Parque Olímpico. Um estudo concluído em 2012 pelo Programa de Engenharia Civil da Coordenação dos Programas de Pós-Graduação em Engenharia (Coppe/UFRJ) relatou que a situação era tão grave que existia risco de colapso, embora não fosse possível precisar quando isso poderia acontecer. A solução de engenharia adotada pelo corpo técnico do município para o Elevado de Joá foi inutilizar os dentes Gerber (responsáveis pela transferência de carga das vigas para os pórticos), desgastados pela corrosão causada pelo mar, por infiltrações provocadas pela água da chuva e pelo tráfego de veículos. Foram implantadas 128 vigas metálicas, que assumiram o peso de toda a estrutura (32,5 toneladas), antes suportado pelos quase 2000 dentes internos. A reforma da via, pela qual passam 42 mil veículos por dia, custou $\mathrm{R} \$ 66,5$ milhões. Esta não foi a primeira vez que a Coppe detectou riscos de colapso na estrutura. Em 1988, especialistas identificaram corrosões em outras partes da estrutura. $\mathrm{Na}$ época, a recuperação levou três anos e custou 8 milhões de dólares (MAGALHÃES, 2012; ENGELBRECHT, 2014).

O modelo clássico do processo de deterioração associado a corrosão das armaduras estabelece dois períodos durante a vida útil de uma estrutura de concreto armado: iniciação e propagação (TUUTTTI, 1982). O período de iniciação é definido como o tempo transcorrido até que comece propriamente a corrosão das armaduras. Alguns dos fatores que facilitam a corrosão causada por íons cloreto nas armaduras são: baixa espessura de concreto de cobrimento das armaduras, baixa qualidade do concreto, adensamento e cura não adequados. Os íons cloreto podem difundir-se através dos micro poros do concreto de cobrimento e a corrosão tem início quando a concentração de cloretos na superfície das armaduras atinge o valor limite. Um fator 
facilitador para a iniciação da corrosão é a presença de fissuras suficientemente grandes para permitir o ingresso direto de cloretos e outros agentes necessários na reação de corrosão (oxigênio, água, etc.). Já o período de propagação é definido como o tempo transcorrido desde a despassivação das armaduras até o final da vida útil da estrutura. Neste período a capacidade mecânica do aço é reduzida, assim como há uma redução da área de aço das seções transversais das barras devido à participação do metal nas reações químicas corrosivas. Os produtos resultantes dessas reações químicas possuem um volume maior do que os componentes originais da reação, causando assim tensões internas que resultam em micro fissuras e, em estágios avançados, é possível ocorrer a fissuração longitudinal externa e o lascamento (spalling em inglês) do concreto, conforme pode ser visto na Figura 1.1. Outro efeito que ocorre durante o período da propagação é uma alteração no mecanismo de transferência de tensões entre o aço e o concreto.

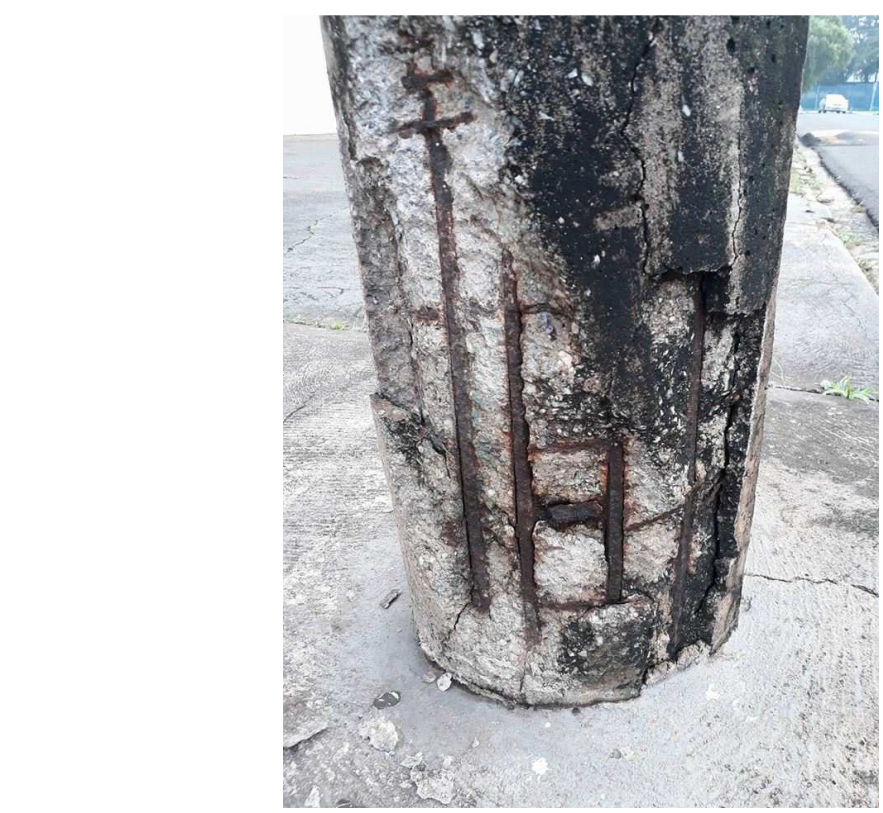

Figura 1.1 - Corrosão avançada das armaduras de um elemento de concreto armado Fonte: arquivo pessoal

Diversos estudos apontam que, devido aos diversos mecanismos deletérios ocasionados pela corrosão, após o início do período de propagação a segurança estrutural decai num intervalo de tempo muito curto se comparado com a duração do período de iniciação (ENRIGHT e FRANGOPOL, 1998; WEYERS, 1998; VIDAL et al., 2007; EL HASSAN et al., 2010; DANG e FRANÇOIS, 2013; PELLIZZER, 2015; PELLIZZER et al., 2018). Assim sendo, é de fundamental importância modelar adequadamente o processo de ingresso de íons cloreto no concreto para que assim seja possível estimar o tempo para que ocorra a despassivação das armaduras de aço. 
A penetração de íons cloreto no concreto é um processo dinâmico e não-linear, incluindo diversos mecanismos de transporte como a difusão iônica, absorção capilar, permeação, etc. (ERLIN e VERBECK, 1975; KROPP, 1995; CASCUDO, 1997; NEVILLE, 2011). A absorção capilar ocorre normalmente em camadas superficiais que estão submetidas a ciclos de molhagem e secagem, afetando somente profundidades de concreto entre 10 e $20 \mathrm{~mm}$ (WEYERS et al., 1993; TUUTTI, 1996). Já a permeação, que ocorre devido a um gradiente de pressão, é raramente encontrada em estruturas de concreto e sua influência pode ser mínima (BODDY et al., 1999; STANISH et al., 2000;). Assim, considera-se que a difusão possua efeito dominante no processo de transporte de íons cloreto no concreto (TUUTTI, 1996; MARTÕ, 2000; VAL e STEWART, 2003; ANN et al., 2009).

A difusão de íons cloreto no concreto é modelada frequentemente utilizando-se as leis de Fick (MANGAT e MOLLOY, 1994; VU e STEWART, 2000; SAMSON et al., 2003; VAL et al., 2009; AUDENAERT et al., 2010; GUZMÁN et al., 2011). Fick apresenta duas leis. A primeira é aplicável à difusão em estado estacionário. A segunda lei, que representa uma condição transiente, pode ser escrita em função do tempo de exposição aos cloretos. A segunda lei de difusão de Fick é aplicável a materiais homogêneos, isotrópicos e inertes e assume que as propriedades mecânicas no processo de difusão sejam iguais em todas as direções do espaço e se mantenham constantes ao longo do tempo (CRANK, 1975). Além disso, algumas desvantagens de boa parte das soluções apresentadas para as equações diferenciais que descrevem as leis de Fick é que são soluções obtidas a partir de domínios semi infinitos e que possuem condições de contorno constantes ao longo do tempo.

Existem outras soluções analíticas disponíveis na literatura para tratar do fenômeno da difusão. Contudo, tais soluções apresentam elevadas simplificações ou podem ser aplicadas a poucos casos específicos. Para modelar a corrosão do aço em estruturas de concreto armado deve-se conhecer tanto o processo de corrosão quanto os efeitos associados à estrutura. A validação de grande parte dos modelos de previsão é limitada, pois tais modelos foram desenvolvidos com uma série de restrições ou condições próprias do modelo (OTIENO et al., 2010; LI et al., 2012). Assim, definir um modelo geral para a previsão da corrosão em estruturas de concreto armado é um desafio.

Com o objetivo de contornar tais limitações e buscar uma ferramenta mais abrangente, no presente trabalho é proposto o desenvolvimento de uma ferramenta numérica que seja capaz de modelar o fenômeno adequadamente. A modelagem é uma ferramenta útil para fornecer uma compreensão quantitativa dos processos chave e suas interações que definem a vida útil do concreto armado em ambientes com cloretos (SHI et al., 2012). 
O método dos elementos de contorno (MEC) tem sido amplamente empregado na modelagem e solução de problemas de engenharia. Dentre as principais vantagens deste método numérico destaca-se a possibilidade de redução da dimensão do problema, fácil conformação às fronteiras do domínio, eliminação da malha de domínio, facilidade para tratar de singularidades, ausência de aproximações das equações governantes do problema, possibilidade de analisar problemas de fronteira móvel e domínios infinitos. Outra grande vantagem do método, especificamente quando aplicado a problemas de difusão, é a redução do tempo de processamento se comparado com outros métodos numéricos (ITAGAKI, 1985; ARAL e TANG, 1988; BOKOTA e ISKIERKA, 1995; TAGUTI, 2010; YANG et al., 2013; CHEN e LEUNG, 2015).

Considerando-se que é de extrema importância prever adequadamente quando se dará o início do período de propagação da corrosão (ou, equivalentemente, o final do período de iniciação), o presente trabalho procura propor um modelo baseado no MEC para tal fim. Dentre as vantagens do modelo proposto destaca-se a possibilidade de variação das condições de contorno ao longo do tempo e a possibilidade de analisar domínios bidimensionais com contornos de geometrias quaisquer. Assim sendo, a formulação aqui apresentada busca ser um encaminhamento para uma modelagem mais fidedigna da realidade do fenômeno.

Além disso, é vastamente reportado na literatura que o processo de difusão de íons cloreto é altamente aleatório. A incerteza presente neste problema pode ser analisada sob um ponto de vista probabilístico à luz da teoria de confiabilidade. Assim procedendo, é possível estimar as variações no nível de segurança da estrutura ao longo do tempo.

Acoplada a análise de confiabilidade pode-se também realizar uma análise de otimização sob incertezas. Dentre os parâmetros que podem ser otimizados pode-se ter o cobrimento do concreto ou até mesmo os custos de construção e manutenção do elemento estrutural. Tal tipo de análise é justificável tendo-se em vista a economia e racionalização do projeto estrutural.

A contribuição desta tese traduz-se na realização da modelagem e análise da vida útil de estruturas de concreto armado submetidas à penetração de íons cloreto por meio da formulação do MEC. A originalidade da presente pesquisa consiste no acoplamento da metodologia do MEC com algoritmos de confiabilidade e de otimização sob incertezas. É descrita a formulação do problema e o esquema de resolução do mesmo, implementados computacionalmente. A partir de tais acoplamentos, resultados exemplificadores são apresentados por meio de curvas de isoprobabilidade de despassivação traçadas no domínio de uma seção transversal de concreto armado e curvas de parâmetros otimizados para níveis de segurança alvo desejados. 


\subsection{Organização da tese e síntese dos capítulos}

Esta tese está organizada em cinco capítulos, abordando temas referentes à durabilidade estrutural, iniciação da corrosão de armaduras em concreto armado por meio da difusão de íons cloreto, método dos elementos de contorno (MEC), confiabilidade estrutural e otimização estrutural baseada em confiabilidade.

No capítulo um, após serem feitas considerações iniciais sobre o assunto tratado, apresenta-se uma revisão bibliográfica que foi dividida por temas específicos para uma melhor organização e compreensão do estudo feito. Os temas apresentados na revisão bibliográfica referem-se a: estudos via abordagens determinísticas, estudos experimentais, estudos utilizando o método dos elementos de contorno e estudos envolvendo confiabilidade e otimização. Por fim são especificados os objetivos, a metodologia e as delimitações da tese.

O método dos elementos de contorno aplicado a problemas de difusão é o tema do capítulo dois. Inicialmente é introduzida a formulação do método para a solução de problemas em regime de difusão estacionário. Valendo-se dos conceitos e metodologia até então introduzidos, apresenta-se a formulação para a solução de problemas em regime de difusão transiente. Em ambos os regimes de difusão são feitos comentários a respeito da implementação computacional realizada. Exemplos de aplicação para validação do código computacional, bem como discussões a respeito de sua aplicabilidade e desempenho constam no fim do capítulo.

O capítulo três trata dos aspectos ligados a confiabilidade estrutural. São apresentadas algumas definições, conceitos, algoritmos e métodos que objetivam determinar o índice de confiabilidade e a probabilidade de falha. Comentários são feitos a respeito de índices de confiabilidade recomendados em normas internacionais e é apresentada uma discussão a respeito do estado limite de iniciação da corrosão. O acoplamento entre o modelo de difusão via MEC e o método de simulação de Monte Carlo é demonstrado por meio de exemplos de aplicação, comparando-se as probabilidades de despassivação obtidas com a resposta fornecida por modelos analíticos. As limitações de tais modelos analíticos são evidenciadas.

O capítulo quatro tem como foco a otimização estrutural baseada em confiabilidade. Após a introdução e motivação do tema, são discorridos os conceitos fundamentais envolvidos em problemas de otimização, bem como os diferentes tipos de abordagem de otimização estrutural. Prontamente, são apresentados dois algoritmos para a solução de problemas de otimização baseados em confiabilidade. Finalmente, exemplos de aplicação de tais algoritmos são apresentados no processo de otimização da espessura de cobrimento de estruturas de concreto armado sob a difusão de íons cloreto. 
Compondo a parte final da tese, no capítulo cinco estão descritas as conclusões obtidas no desenvolvimento do trabalho e são sugeridos alguns tópicos para pesquisas futuras.

\subsection{Estado da arte}

Nesta seção apresentam-se alguns trabalhos científicos importantes que constam na literatura. Com o intuito de facilitar o estudo e leitura do texto, optou-se por organizar as referências segundo temas específicos: estudos dos mecanismos de transporte via abordagens determinísticas (seção 1.3.1), estudos experimentais (seção 1.3.2) e estudos utilizando o método dos elementos de contorno (seção 1.3.3).

\subsubsection{Estudos via abordagens determinísticas}

O modelo conceitual clássico de vida útil de estruturas de concreto armado submetidas à corrosão foi proposto por Tuutti (1982) e é amplamente conhecido e divulgado no meio técnico. A vida útil estrutural é dividida em duas fases no modelo de Tuutti: iniciação e propagação.

O período de iniciação corresponde ao tempo transcorrido entre a execução da estrutura e o instante em que os agentes agressivos, como os íons cloreto ou o dióxido de carbono, possuem uma concentração tal ao redor das armaduras suficiente para despassivá-las. Durante esse período, devido a porosidade da matriz de cimento do concreto, ocorre o ingresso e transporte dos agentes agressivos para o interior do concreto. A difusão iônica e de gases, a permeabilidade, a absorção capilar e a migração de íons são alguns dos mecanismos de transporte responsáveis por esse processo. Tais mecanismos podem agir de forma combinada ou isoladamente, possuindo maior ou menor relevância, conforme o caso tratado. Os mecanismos de transporte são influenciados basicamente por fatores relacionados: ao ambiente no qual a estrutura está inserida, às características do concreto e aos esforços agindo sobre a estrutura. Dentre os fatores ambientais podem ser citados a incidência solar, o vento, a chuva, a temperatura e a umidade relativa do ar. A relação água/cimento (diretamente relacionada a porosidade do concreto), o tipo e teor de cimento, o processo de cura, adições, entre outros, são fatores relacionados às características do concreto. Por fim, os esforços agindo sobre a estrutura, traduzido em termos de tensões atuantes, alteram a capacidade do material em transportar agentes agressivos.

O segundo período descrito por Tuutti (1982), o da propagação, corresponde ao desenvolvimento do processo corrosivo até níveis inaceitáveis de deterioração. Durante esse período ocorrem efeitos mecânicos deletérios tanto no aço como no concreto. Entre tais efeitos mecânicos pode-se citar a redução da área de aço das armaduras, a alteração dos mecanismos de 
aderência entre aço/concreto, a fissuração do concreto de cobrimento decorrente dos produtos expansivos originados por meio das reações químicas do fenômeno e a redução da tensão de escoamento das armaduras.

É importante destacar que o modelo de Tuutti (1982), assim como qualquer outro modelo para descrição da vida útil de estruturas, não se refere a vida útil da estrutura como um todo, mas sim a regiões específicas dos elementos estruturais constituintes. A corrosão é uma manifestação patológica que ocorre em alguns pontos ou regiões da estrutura, tendo cada um desses pontos ou regiões períodos distintos de iniciação e propagação. A natureza altamente aleatória dos parâmetros que governam o fenômeno ajuda a compreender essa diferença. Assim, os períodos de iniciação e propagação ocorrem paralelamente numa mesma estrutura ou mais ainda, num mesmo elemento estrutural. Portanto o final da vida útil da estrutura ocorre quando o conjunto de degradações presentes nos elementos estruturais atinge um nível em que o desempenho estrutural é insatisfatório.

Conforme já mencionado anteriormente, a difusão é o mecanismo de transporte de cloretos predominante no concreto. A palavra "difundir", do latim diffundere, significa derramar ou verter, transmitindo a ideia de espalhar um líquido. Genericamente a difusão é definida como o movimento atômico ou de moléculas de uma região com alta concentração (ou alto potencial químico) para uma região de baixa concentração (ou baixo potencial químico). A difusão é o resultado de um processo de movimento aleatório dos átomos ou moléculas. A compreensão de tal mecanismo é fundamental para descrever o período de iniciação da corrosão.

$\mathrm{Na}$ ciência moderna, os primeiros estudos referentes à difusão foram feitos pelo químico escocês Thomas Graham (1805-1869). Com 28 anos de idade, Graham apresentou à Real Sociedade de Edimburgo a sua descoberta, de que a taxa de difusão de um gás é inversamente proporcional à raiz quadrada de sua densidade. Mais tarde, tal descoberta viria a ser denominada "lei de Graham". Graham publicou cerca de 70 trabalhos nas áreas de química, termodinâmica, difusão de gases e líquidos, diálise, osmose, fenômenos coloidais e constituição da matéria. Contudo, os resultados mais importantes de seus estudos estão relacionados à difusão (WISNIAK, 2013; WISNIAK, 2013 ${ }^{\text {b) }}$.

Thomas Graham não imaginava que seus elegantes experimentos de difusão em gases e de sal na água poderiam ter uma grande influência na história de um alemão chamado Adolph Eugen Fick (1829-1901). Fick tinha um interesse especial por matemática e queria se tornar matemático, mas sua família o convenceu a estudar medicina, carreira que seguiu até o fim da vida. Contudo, Fick tinha a convicção de que os fundamentos em medicina deveriam ser baseados na matemática, física e química. Inclusive, em 1856, ele publicou um livro de 
originalidade ímpar intitulado "Física médica", tratando temas como a mistura de ar nos pulmões, o trabalho do coração, a economia de calor do corpo humano, a mecânica da contração muscular, a hidrodinâmica da circulação sanguínea, entre outros. Um ano antes, em 1855, Fick publicou seu primeiro trabalho sobre difusão. Utilizando uma analogia entre a lei de Fourier de condução térmica (ou a lei de Ohm para condução elétrica) ele desenvolveu a teoria matemática para o fenômeno. Ele postulou que o fluxo de sal ocorrendo em uma unidade de tempo entre dois volumes infinitesimais preenchidos com soluções do mesmo sal, mas com diferentes concentrações de sal deve ser diretamente proporcional à diferença de concentração e inversamente proporcional à distância entre os volumes de teste. Em outras palavras, em uma notação moderna, Fick postulou que o fluxo de uma dada substância em uma dada direção é proporcional ao gradiente da concentração dessa substância. Tal postulação recebeu o nome de primeira lei de Fick. Já a segunda lei de Fick diz que a variação no tempo da concentração de dada substância é igual a variação do fluxo dessa substância por unidade de comprimento. $\mathrm{Na}$ literatura relacionada a matemática aplicada, a segunda lei de Fick é na maioria das vezes reportada como sendo a "equação de calor", pois foi aplicada primeiro para descrever a transferência de calor. Uma melhor expressão poderia ser "equação de difusão", pois ela descreve a difusão de alguma coisa, como por exemplo o calor ou o ingresso de cloretos dentro do concreto. Dentre as contribuições mais importantes de Fick para o estudo da difusão pode-se citar a introdução das equações fundamentais que governam o fenômeno, a definição do coeficiente de difusão e as medições experimentais para o cálculo do coeficiente de difusão do sal na água (PHILIBERT, 2005; POULSEN e MEJLBRO, 2006; MEHRER e STOLWIJK, 2009). Outros detalhes sobre as equações descritas por Fick podem ser encontradas no livro de Shewmon (2016).

Os dados publicados por Graham auxiliaram os estudos de outro cientista escocês chamado James Clerk Maxwell (1831-1879). Maxwell é mais conhecido por ter formulado a teoria clássica da radiação eletromagnética e pelas notórias “equações de Maxwell” do eletromagnetismo. Em 1867, a partir dos resultados numéricos de Graham, Maxwell calculou o coeficiente de difusão de gases. Para o coeficiente de difusão do dióxido de carbono a precisão obtida foi em torno de 5\%. Além disso, Maxwell desenvolveu a primeira teoria atomística para o processo de transporte de gases (MEHRER e STOLWIJK, 2009).

A teoria moderna atomística de difusão e movimento browniano foi desenvolvida pelo físico alemão Albert Einstein (1879 - 1955), pelo físico austríaco Marian von Smoluchowski (1872 - 1917) e pelo físico francês Jean Baptiste Perrin (1870 - 1942). O equacionamento de 
processos de transportes macroscópicos deve-se ao físico austríaco Ludwig Boltzmann (1844 1906), que introduziu a equação que recebe seu nome (CHAPMAN e COWLING, 1970).

Ainda no final do século XIX e até metade do século XX, podem ser citados alguns outros cientistas que conduziram relevantes estudos experimentais e teóricos a respeito do fenômeno da difusão: Sir William Chandler Roberts-Austen (1843 - 1902), Svante Arrhenius (1859 - 1927), Georg Karl von Hevesy (1885 - 1966), Walter Schottky (1886 -1976), Jakov Ilich Frenkel (1894 - 1952) e Chujiro Matano (1905 - 1947).

Já num contexto de engenharia, o trabalho pioneiro que buscou modelar o ingresso de cloretos especificamente no concreto foi o de Collepardi et al. (1970). O modelo proposto pelos autores deriva da solução da equação diferencial que define a segunda lei de Fick, considerando a difusão como sendo unidimensional e sendo tanto a concentração superficial de cloretos quanto o coeficiente de difusão do concreto constantes no tempo e no espaço.

No final dos anos de 1980, diversas observações em laboratório e em campo revelaram que o ingresso de cloretos não ocorria conforme previsto pelo modelo de Collepardi et al. (1970), podendo ocorrer inclusive grandes erros no cálculo da concentração de cloretos ao longo do tempo. Alguns estudos que podem ser citados neste período histórico são os de Dauvergne (1982), Pourbaix et al. (1982), Browe (1982) e Midgley e Illston (1984). Os argumentos levantados na discussão envolviam a influência da qualidade do concreto utilizado e se havia de fato uma conectividade suficiente de poros no concreto que permitisse a ocorrência do fenômeno. Sørensen (1996) demonstrou em um modelo computacional com conectividade limitada que o ingresso de cloretos apareceria como um perfil normal de ingresso, porém poderia não se desenvolver no tempo estimado pelo modelo de Collepardi et al. (1970). Além disso, atualmente sabe-se que a consideração de um coeficiente de difusão constante é coerente somente para estruturas de concreto expostas a cloretos por um tempo muito elevado. Isto se deve ao fato de que para períodos significativos de exposição, a difusividade de cloretos no concreto apresenta um comportamento constante (regime de difusão estacionário).

No decorrer dos anos seguintes, muitos pesquisadores começaram a estudar a difusão de cloretos no concreto considerando a variação do coeficiente de difusão e da concentração superficial de cloretos dependentes de alguns fatores. Dentre esses fatores destaca-se o tempo, o espaço, a taxa de ligação de cloretos à matriz de cimento, a composição do concreto e o nível de dano/fissuração no concreto de cobrimento devido ao carregamento.

A quantidade total de cloretos que se difundem nos poros do concreto pode ser dividida em dois grupos: cloretos livres e cloretos ligados. Os cloretos ligados são aqueles que ao longo do processo difusivo são ou fisicamente absorvidos nos poros ou reagem quimicamente com os 
produtos de hidratação. Os cloretos ligados não contribuem para a despassivação das barras dentro do concreto, uma vez que estão "presos" e assim não estão mais disponíveis para as reações corrosivas com o metal que compõe as armaduras. Assim, parte dos cloretos ligados reagem quimicamente especialmente com o aluminato tricálcico e ferro-aluminato de cálcio, presentes no cimento. O produto de tal reação é o cloro-aluminato de cálcio hidratado (conhecido também como sal de Friedel), que possui uma estrutura menos porosa e assim acaba reduzindo o transporte de íons cloreto. A ligação dos cloretos no concreto afeta a taxa de ingresso de cloretos, o que determina o tempo de iniciação da corrosão. Por outro lado, tem-se os cloretos livres, sendo os responsáveis pela corrosão das armaduras de aço. A consideração da ligação de cloretos durante o processo difusivo é normalmente modelada por meio de expressões matemáticas chamadas de "isotermas de cloretos". Essas isotermas são representadas em equações e gráficos que descrevem a relação entre a concentração de cloretos totais e a concentração de cloretos ligados. As isotermas mais utilizadas são as lineares, as de Langmuir e as de Freundlich. As isotermas são obtidas empiricamente, desprezando-se a taxa de reação de cloretos, e buscam substituir expressões termodinâmicas mais apropriadas para o processo. Dois parâmetros em especial são importantes para avaliar a capacidade de ligação entre a pasta e os cloretos. O primeiro é a relação entre o gel de C-S-H e o concreto, que determina o efeito da composição do cimento e a idade na fração de volume de C-S-H. O segundo parâmetro é a razão entre o volume de solução de cloretos nos poros e a massa de concreto. Quando o efeito de ligação de cloretos é considerado, a concentração de cloretos livres é reduzida de tal forma que o coeficiente de difusão de cloretos é reduzido também. Assim, modelos que consideram esse efeito têm como resultado maiores períodos de iniciação da corrosão (TUUTTI, 1982; COLLEPARDI, 1995; MCGRATH 1996; XI e BAZANT, 1999; GLASS e BUENFELD, 2000; ELSENER e ANGST, 2007; HAN, 2007; AL-KUTTI, 2011; ANDRADE 2016).

Ainda com relação às isotermas, cabe destacar que diversos estudos apontam que a relação entre os cloretos ligados e os cloretos livres é não linear (SERGI et al., 1992; NILSSON et al. 1994; TANG e NILSSON, 1993; TRITTHART, 1989). Uma isoterma linear subestima a quantidade total de cloretos ligados em baixas concentrações de cloreto totais, enquanto que superestima a quantidade de cloretos ligados em altas concentrações de cloretos totais. Contudo, considerar tal relação como sendo linear é uma forma de resolver mais facilmente a equação diferencial da difusão (SAETTA et al., 1993; NILSSON et al., 1996; MARTÍN-PEREZ et al., 2000).

Um dos primeiros estudos com relação à ligação química entre os cloretos e a matriz de cimento foi realizado por Glass e Buenfeld (1997). Os autores concluíram que o teor livre de 
cloretos ou a taxa de concentração de cloretos hidroxila nos poros do concreto, em relação ao peso de cimento, é a melhor forma de representar o conteúdo de cloretos necessários para desencadear a corrosão. Ou seja, os níveis limite de cloretos são melhor representados como o potencial total agressivo do conteúdo de íons expresso em relação ao potencial total de conteúdo inibidor.

Outro trabalho bastante interessante é atribuído a Xi e Bazant (1999). Os autores apresentam um modelo matemático baseado na primeira lei de Fick para a penetração de cloretos em concretos saturados considerando a relação água/cimento, tempo de cura, tipos de cimento, conteúdo de agregados e temperatura. A capacidade de ligação química de cloretos é modelada por meio da média da isoterma de adsorção de cloretos. A difusividade de cloretos é modelada por meio de uma teoria de materiais compósitos apresentada por Christensen (1979). O concreto é considerado como sendo um material de duas fases com o agregado sendo uma fase e a pasta de cimento outra. A difusividade para a pasta de cimento é caracterizada pelo modelo de KozenyCarman com as modificações feitas por Martys et al. (1994). A equação da difusão é resolvida por meio do método das diferenças finitas. Os perfis previstos de penetração de cloretos estão razoavelmente de acordo com resultados de testes experimentais apresentados.

Por outro lado, Alonso et al. (2000) realizaram um estudo que apresenta níveis limite de cloretos em argamassas, expressos pela razão do total de $\mathrm{Cl}^{-} / \mathrm{OH}^{-}$livre (íons cloreto/hidroxila livre). Os autores argumentam que um dos motivos encontrados para a dispersão de valores da quantidade de cloretos para a despassivação do aço, encontrados em numerosos estudos anteriores, é o grande número de variáveis que influenciam o problema. O outro motivo é a falta de concordância para a definição do próprio nível limite de cloretos, seja na determinação dos parâmetros (observação visual, potencial de corrosão ou corrosão atual) ou na expressão do nível limite (como a razão $\mathrm{Cl}^{-} / \mathrm{OH}^{-}$ou em peso de cimento ou concreto).

Martõ (2000) em seu modelo propôs uma modificação na segunda lei de Fick para englobar o efeito da ligação de cloretos no concreto. Essa modificação é feita calculando-se um coeficiente de difusão chamado de "aparente", sendo função da taxa de variação da concentração de cloretos ligados quimicamente com relação à concentração total de cloretos. Essa taxa de variação é obtida a partir de isotermas de concentração de cloretos. Tumidajski (1996) adota uma abordagem parecida, porém introduzindo uma variável representado a taxa de ligação de cloretos como um termo adicional na equação diferencial e não diretamente no coeficiente de difusão. Em sua abordagem, Tumidajski (1996) utiliza a solução da equação diferencial fornecida por Danckwerts (1950). 
Um modelo englobando simultaneamente reações químicas e mecanismos de difusão dependentes do tempo e do espaço para determinar o perfil de cloretos ao longo do tempo e da profundidade do concreto é proposto por Sun et al. (2012). O modelo analítico desenvolvido é baseado na segunda lei de difusão de Fick e numa formulação matemática para reações químicas não reversíveis de primeira ordem. Quando as reações químicas são consideradas, a concentração de cloretos livres é levemente reduzida simultaneamente com a redução do coeficiente de difusão. O modelo não inclui muitas propriedades do concreto, nem mesmo a relação água/cimento como parâmetro de entrada. Outra limitação desse modelo decorre da necessidade de resultados experimentais para ser utilizado.

Conforme já comentado anteriormente, o coeficiente de difusão do concreto não é constante. Tal parâmetro varia conforme o tempo e o espaço conjuntamente. A estrutura dos poros do concreto depende principalmente da relação água/cimento, do grau de hidratação, da temperatura e do tipo de cimento (LIANG et al., 2010; SUN et al., 2012; KHAN, 2013).

Considere um ponto fixo no espaço dentro de um corpo de concreto submetido ao ingresso de cloretos. Para este ponto, o coeficiente de difusão diminuirá com o avanço do tempo pois a estrutura dos poros é alterada devido a formação dos produtos da hidratação. Em outras palavras, os produtos da hidratação do concreto tornam os poros do concreto e sua conectividade cada vez menores, dificultando a passagem dos íons cloreto.

Para este mesmo corpo de concreto submetido ao ingresso de cloretos, fixa-se agora o tempo e varia-se a profundidade de observação. Considerando que o concreto não tenha cloretos previamente incorporados a sua matriz (portanto o concreto está inicialmente livre de cloretos), quão mais em profundidade se observar o corpo de concreto menor será a concentração de cloretos e maior será o coeficiente de difusão. A concentração de cloretos diminui com a profundidade conforme intuitivamente esperado de um processo difusivo. Considerando que em profundidades rasas (próximas a superfície de exposição aos cloretos) existe uma grande concentração de cloretos, o gradiente de concentração é menor o que resulta em um pequeno coeficiente de difusão. Por outro lado, em pontos mais profundos do corpo de concreto, a concentração de cloretos é menor e, portanto, o gradiente de concentração é maior, resultando em um coeficiente de difusão maior.

Com o objetivo de considerar a variação do coeficiente de difusão no tempo, Maage et al. (1995) propuseram uma expressão para o seu cálculo relacionando um coeficiente de difusão de referência aos vinte e oito dias com a razão entre o tempo de referência e o tempo para o cálculo do coeficiente elevado a um fator " $\mathrm{m}$ ". Tal fator depende das características do concreto utilizado 
(NOKKEN et al., 2006). Desta forma é possível considerar o coeficiente de difusão como tendo um comportamento de redução exponencial e tendendo a um valor fixo.

Um outro estudo considerando inclusive a variação da umidade no processo difusivo foi feito Ababneh et al. (2003) para concretos não saturados. Os autores utilizam duas equações para descrever o processo: uma para a difusão de íons cloreto e a outra para a umidade. O método das diferenças finitas é utilizado para resolver as equações diferenciais acopladas que governam o problema. São feitas diversas considerações a respeito dos parâmetros envolvidos no modelo como a capacidade de ligação química dos cloretos, coeficiente de difusão de cloretos e coeficiente de difusão da umidade. Cada um desses parâmetros é calibrado baseado em dados experimentais. Segundo os autores o modelo simula satisfatoriamente o perfil de cloretos obtidos em testes normatizados de 90 dias de penetração de cloretos. Contudo, nada se pode dizer a respeito do comportamento do modelo em idades mais avançadas. Os testes numéricos mostram que a difusão da umidade acelera a penetração de cloretos.

Além do coeficiente de difusão, outro importante parâmetro que governa o problema é a concentração superficial de cloretos. Diversos estudos foram feitos com relação a influência desse fator na iniciação da corrosão das armaduras. Kassir e Ghosn (2002) desenvolveram uma solução fechada para prever o tempo de iniciação da corrosão em tabuleiros de pontes de concreto armado usando medidas tomadas ao longo do tempo da acumulação de cloretos na superfície. O banco de dados para os cloretos de superfície foi obtido a partir de medições em corpos de prova extraídos em profundidades rasas, próximas a superfície, de 15 tabuleiros de pontes na região dos grandes lagos nos EUA, onde há muita neve e consequentemente onde usam-se muitos sais de degelo, com o objetivo de diminuir o ponto de fusão de água e assim derreter a neve. O banco de dados foi coletado durante inspeções bienais nas pontes durante um período de 15 anos. Uma análise de regressão é utilizada para representar os cloretos de superfície por meio de uma variação exponencial com o tempo. Os autores partem da equação diferencial que define a lei de Fick unidimensional e a resolvem considerando essa variação exponencial da concentração superficial de cloretos ao longo do tempo. O tempo previsto para a iniciação da corrosão é calculado para diferentes valores de coeficientes de difusão efetivos e espessuras de cobrimento de concreto. Os resultados indicaram que a iniciação da corrosão baseada na acumulação constante de cloretos na superfície é mais rápida (em alguns casos em até 100\%) do que o tempo de iniciação calculado a partir de dados reais de concentração de cloretos. Além disso, os autores observaram grandes diferenças (de até 100\%) no tempo de iniciação de corrosão entre locais expostos a baixas concentrações de cloretos e aqueles expostos a altas concentrações. 
O modelo de Kassir e Ghosn (2002) não leva em consideração a variação do coeficiente de difusão com o tempo. Neste sentido, o trabalho apresentado por Maheswaran e Sanjayan (2004), além de levar em consideração a variação superficial de cloretos, considera o coeficiente de difusão também variável no tempo. Os autores propõem uma solução analítica para a equação diferencial da difusão considerando uma variação temporal para esses dois parâmetros. Para o coeficiente de difusão a variação proposta é igual àquela descrita por Maage et al. (1995) e a variação da concentração superficial de cloretos é descrita por duas leis: uma linear e outra exponencial. Os autores utilizam o princípio da superposição para calcular o perfil de concentração de cloretos. Os resultados alcançados estão de acordo com aqueles obtidos utilizando um software comercial chamado Life-365, que utiliza o método das diferenças finitas na solução da equação diferencial que governa o problema. Os autores argumentam que o método por eles proposto é mais rápido e eficiente. Contudo, deve-se destacar que a solução por eles apresentada considera uma difusão unidimensional e desconsidera a capacidade de ligação dos cloretos.

Ann et al. (2009) realizaram simulações considerando a concentração de cloretos na superfície como sendo expressa em função do tempo de quatro formas: constante, acúmulo linear, acúmulo de raiz quadrada e por último um modelo mais refinado com acúmulo de raiz quadrada com um conjunto inicial de conteúdo de cloretos. Nas análises o coeficiente de difusão é mantido constante. Os autores partem da equação diferencial da lei de Fick e a resolvem para cada tipo de consideração de concentração superficial de cloretos. O modelo considerando uma constante concentração de cloretos produziu os maiores níveis de penetração de cloretos. A taxa de ingresso de cloretos obtida da maior concentração de cloretos de superfície conduziu ao maior risco de corrosão das armaduras no concreto, onde os modelos de acúmulo linear e de raiz quadrada produziram períodos de vida útil sem o início da corrosão de 2 a 3 vezes maiores. Os autores concluem que considerar o coeficiente de difusão constante com o tempo não é adequado para uma análise mais realística. Outra análise bastante parecida com essa foi realizada por Zhou (2016) somente considerando o acúmulo superficial de cloretos conforme a raiz quadrada do tempo de exposição, porém variando-se o coeficiente de difusão com o tempo.

Um questionamento a respeito dos modelos pode se dar também com relação a sua representatividade de problemas reais quanto a natureza espacial do fenômeno da difusão. Muitos dos modelos reportados na literatura consideram uma difusão unidirecional, sendo possível a sua aplicação prática em alguns poucos casos. Nesse sentido, alguns trabalhos procuraram verificar a influência de estados de difusão bi e tridimensionais em elementos de concreto. Zhang et al. (2011) estudaram o ingresso de cloretos em concretos com cinzas volantes, expondo corpos de 
prova cúbicos a uma solução com cloretos. $\mathrm{Na}$ pesquisa feita, simulou-se em laboratório as condições de ingresso de cloretos em uma, duas e três direções do espaço, ora isolando (com epóxi) e ora expondo (a uma solução de cloretos) cada par de faces opostas do corpo de prova cúbico. Os coeficientes de difusão obtidos foram 2,01 e 2,27 maiores para as análises 2D e 3D do que para a análise em uma dimensão. Esse resultado reforça a importância de prestar-se atenção ao ingresso de cloretos especialmente em quinas de peças de concreto armado.

Outro ponto de bastante interesse dos pesquisadores relaciona-se à modelagem da difusão em estruturas de concreto submetidas a estados de tensão e eventualmente apresentando estados de danificação. Espera-se que a difusividade de cloretos em um concreto danificado seja maior do que em um concreto são (DANCKWERTS, 1950; BENTZ et al., 2013; SHAO e LI, 2014). Gérard e Marchand (2000) relataram que a difusividade de cloretos pode aumentar entre 2 a 10 vezes devido a fissuras no concreto. Vários mecanismos podem produzir fissuras no concreto: retração plástica, retração autógena (capilares), retração por secagem, carregamentos mecânicos e térmicos, problemas de projeto como carregamentos não previstos, reações expansivas degradadoras, entre outros. Não considerar razoavelmente a fissuração do concreto pode resultar em uma superestimativa da vida útil de uma estrutura (ZHANG et al., 2017).

Gowripalan et al. (2000) investigaram o efeito das armaduras na difusividade de cloretos em zonas de tensão e de compressão em peças de concreto fissurado sob flexão. O coeficiente de difusão aparente na zona de tração resultou maior do que na zona de compressão. Além do fato de que o concreto possui uma resistência bem menor a tração do que a compressão, esse resultado já era esperado, uma vez que esforços de tração tendem a distanciar pontos próximos, fazendo com que o nível de fissuração aumente e, portanto, facilitando a entrada dos agentes agressivos para o interior do concreto. Outros trabalhos que chegaram a conclusões similares são os de Breysse e Gerard (1997), Sahmaran (2007), Guoping et al. (2011) e Wang et al. (2011).

Alguns estudos procuraram utilizar os conceitos da mecânica do dano na investigação da difusividade de cloretos no concreto. Estudos como os de Xing et al. (2005) e Chatzigeorgiou et al. (2005) apresentaram como resultado um aumento significativo da permeabilidade do concreto sob microfissuração. Foi verificada uma boa correlação entre a evolução do dano e a permeabilidade experimentalmente. Pijaudier-Cabot et al. (2009) verificaram que existe uma forte correlação entre o nível de dano e as propriedades de transporte do concreto. O nível de dano é relevante no processo difusivo na presença de microfissuras. Quando, porém, macrofissuras estão presentes no concreto, a permeabilidade é governada por uma função exponencial sob influência da abertura da fissura. 
Ozbolt et al (2010) em seu trabalho, tratam de um modelo numérico para o transporte capilar da água, do oxigênio e dos cloretos através do concreto. A parte mecânica do modelo é baseada num modelo hidro-térmico dependente em micro escala para o concreto. $\mathrm{O}$ dano e a fissuração são modelados dentro do conceito de fissuras contínuas (fraca descontinuidade). A interação entre os processos não mecânicos (distribuição de temperatura, água capilar, oxigênio e cloretos) e as propriedades mecânicas do concreto (dano) é considerada. A aplicação do modelo é ilustrada em um exemplo numérico onde a análise transiente com elementos finitos 3D de uma laje de concreto armado é considerada para investigar a influência do dano do concreto no tempo de despassivação das armaduras. Devido à carga externa, a laje de concreto armado foi parcialmente fissurada antes da exposição à água do mar. Consequentemente, a parte danificada da laje exibe um tempo de despassivação muito menor que aquele das partes não danificadas. Isto ocorre devido a fissuração do concreto, que acelera significativamente processos que são relevantes para a despassivação das armaduras. Contudo, como os autores levam em consideração mecanismos de transporte tanto da água, do oxigênio e dos cloretos, existem muitos parâmetros de entrada no modelo de difícil determinação prática, o que dificulta sua utilização na engenharia corrente. Além disso, no trabalho apresentado, considera-se que a concentração de cloretos seja constante na superfície, o que não é recorrentemente reportado na literatura. Outro trabalho que buscou compreender os mecanismos de transporte acoplados de água e cloretos em corpos de provas de cimento é o de Černý et al. (2004).

Nas pesquisas de Al-Kutti (2011) e Al-Kutti et al. (2014) foram realizadas simulações considerando uma formulação multifísica que acopla o estado de difusão de cloretos em vigas de concreto armado com o estado de danificação e a ligação de cloretos. Experimentalmente foram obtidos os perfis de concentração de cloretos ao longo da profundidade de vigas de concreto armado submetidas a cloretos por 90 dias e danificadas por meio de tensões de flexão. Numericamente as vigas foram simuladas por meio de elementos finitos $2 \mathrm{D}$ incorporando o dano devido às tensões, a ligação química de cloretos aos compostos do concreto e a difusão de cloretos. Foi definido um coeficiente de difusão efetivo em função do nível de dano nos elementos e em função da ligação química de cloretos, obtido por meio da calibração dos dados dos perfis de cloretos determinados para vigas danificadas submetidas a flexão. Usando as expressões obtidas para o coeficiente de difusão efetivo, os perfis de cloretos obtidos numericamente correspondem àqueles obtidos experimentalmente em vigas danificadas para vários níveis de tensão. O coeficiente de difusão sofre aumentos mais expressivos para tensões de tração do que de compressão. Para tensões de tração o coeficiente de difusão aumentou até oito vezes com relação ao coeficiente de difusão do concreto não danificado. Já para tensões de 
compressão esse aumento foi em torno de quase duas vezes apenas. Para níveis baixos de dano (até $40 \%$ da tensão última resistente do concreto aplicada) o coeficiente de difusão não apresentou alteração significativa. Isto se deve ao fato de que em zonas de compressão as fissuras ocasionadas pelo carregamento aparecem transversalmente à direção do fluxo de cloretos, enquanto que em zonas de tração as fissuras possuem uma orientação paralela à direção do fluxo de cloretos.

Outro resultado que reforça a menor influência do estado de fissuração em zonas comprimidas no processo de difusão foi obtido por Lim et al. (2004). Os autores concluíram em seus estudos experimentais que, para cargas de compressão com intensidade de até metade da resistência do concreto, nenhum efeito significativo na penetração de cloretos foi encontrado. Contudo, Rahman et al. (2012) concluíram que o coeficiente de difusão efetivo aumenta três vezes para níveis de tensão correspondentes a $90 \%$ da resistência última do concreto. Em um primeiro momento os autores realizaram uma investigação experimental envolvendo um teste de migração não estacionária, conforme a norma NT BUILD 492, tendo sido realizada em espécimes de concreto não carregados, danificados previamente por cargas axiais de compressão. Em seguida, para efeitos comparativos, foi utilizado um modelo numérico em elementos finitos acoplando dano, uma isoterma linear para a ligação de cloretos e a equação Nernst-Planck. Outra interessante observação dos autores é que a quantidade de cloretos ligados quimicamente correspondeu a cerca de $20 \%$ do teor total de cloretos. Contudo, os coeficientes de difusão tratados no trabalho são para amostras de concreto que, num primeiro momento foram danificadas (aplicação de carga) e, após a remoção do carregamento, foram submetidas a um ensaio de migração iônica. Assim, em uma estrutura de concreto real, a migração iônica pode ocorrer paralelamente a uma evolução do estado de danificação da mesma. Portanto, pode-se intuir que numa estrutura real os coeficientes de difusão serão maiores.

Outro trabalho nessa linha de investigação é feito por Mukhtar e Al-Gadhib (2011). Os autores utilizam a formulação apresentada por Al-Kutti (2011) para realizar a simulação de uma viga de concreto armado, associando o nível de dano presente ao processo de difusão de cloretos. Os autores adotam uma relação linear entre o valor da variável de dano e o valor da tensão presente. Nessa análise em específico os resultados obtidos tiveram uma boa concordância com resultados experimentais. Entretanto, a consideração dessa relação linear possivelmente conduz a grandes erros se o nível de tensão aplicado por bastante elevado, visto a forte relação não linear existente entre a tensão e o nível de danificação.

Uma interessante análise, ainda se tratando do processo de difusão de cloretos em concretos fissurados, foi feita por Wang e Zhang (2016). Os autores focaram seu estudo não 
somente na influência da largura das fissuras nos coeficientes de difusão do concreto. Outras características das fissuras, como a profundidade de cloretos, a forma da fissura (com largura constante ou afunilada), densidade de fissuras e espaçamento, foram estudadas em detalhes. Por meio de um procedimento numérico, baseado no método dos elementos finitos aplicados a problemas bidimensionais, o concreto fissurado é dividido em duas partes, zona sã e zona fissurada. Para o concreto sem tensões, o coeficiente de difusão da zona sã é assumido como sendo o mesmo do concreto são e o coeficiente de difusão da zona fissurada é expresso em uma função por partes conforme a largura da fissura. Os resultados obtidos apresentaram uma boa concordância com resultados experimentais, indicando que com o aumento da largura das fissuras, profundidade da fissura e quantidade de fissuras o ingresso de cloretos será agravado. Contudo, o efeito de carregamentos e tensões na difusão de cloretos não são levados em consideração neste estudo. Para elementos de concreto armado com carregamentos estruturais e fissuras, o concreto ao redor da zona fissurada pode ser danificado devido a tensões de tração ou propagações da zona de processo de fratura. Esse dano irá aumentar o coeficiente de difusão do concreto ao redor da zona fissurada. Para avaliar a vida de serviço de estruturas de concreto armado, considerando a influência do estado de tensão nas propriedades de transporte do concreto, seria necessária uma análise acoplando tensões, propagação de fissuras e transporte de cloretos. Tal tipo de análise permanece ainda uma lacuna a ser preenchida no atual estado da arte da literatura técnica da área.

Já uma análise de difusão acoplada com fissuras internas em estruturas de concreto armado tridimensionais foi realizada por Kurumatani et al. (2017). O método apresentado compreende uma análise da propagação das fissuras no concreto e uma análise da difusão dos íons cloreto. Um modelo em elementos finitos acoplado com um modelo de dano baseado na mecânica da fratura para o concreto foi aplicado para a análise da propagação de fissuras, permitindo uma reprodução da geometria tridimensional das fissuras internas. A análise de difusão dos íons cloreto nas fissuras internas foi feita considerando o coeficiente de difusão expresso em função da variável de dano obtido da análise de propagação de fissuras. É feito um comparativo entre resultados numéricos e experimentais, mostrando que o modelo proposto possibilita, com razoável concordância, uma simulação da penetração de cloretos no concreto com fissuras internas. Contudo, na formulação apresentada, os autores utilizam um parâmetro que é obtido a partir da calibração de resultados experimentais feitos, tornando assim o método dependente de resultados prévios observados.

Outro interessante trabalho é apresentado por Zhang et al. (2017). Dentre os objetivos do trabalho buscou-se como encontrar razoavelmente os valores dos parâmetros para simular o 
processo difusivo de cloretos no concreto fissurado, além de examinar quantitativamente o efeito das fissuras na difusão de cloretos no concreto. Os autores adotaram o modelo de Du et al. (2015) que utiliza elementos finitos e a segunda lei de Fick para determinar a concentração de cloretos ao longo da profundidade. Em seu modelo original, Du et al. (2015) consideram uma simulação em meso escala englobando quatro fases para o material: o agregado, a matriz de pasta de cimento, a zona interfacial de transição entre as duas fases e a fase da fissura. Por simplificação, os autores resolveram remover os agregados e a zona de transição, considerando assim um concreto homogêneo e, portanto, realizando uma simulação em macro-escala. Comparando concretos de resistência alta, normal e baixa, todos com alta porosidade, o comportamento difusivo de cloretos em concretos de alta resistência se mostrou mais sensível a presença de fissuras. Os autores também concluíram que, como a largura da fissura varia com a sua profundidade, significando que os efeitos da largura e profundidade da fissura estão acoplados e que são complexos, é necessário considerar ao mesmo tempo tanto a variação da largura quanto da profundidade da fissura nas análises de difusão de cloretos no concreto fissurado. Cabem algumas outras observações a respeito desse estudo: as fissuras na verdade são tortuosas (não retas) e com larguras variando ao longo da profundidade (não uniformes como considerado); o concreto não é um material homogêneo; efeitos como a capacidade de ligação química dos cloretos aos componentes do cimento, o envelhecimento do concreto, a variação de temperatura e a variação da concentração superficial de cloretos não são levados em consideração. Outros estudos envolvendo a simulação da difusão de cloretos em concreto fissurado utilizando tanto métodos numéricos em micro quanto em macro escala são apresentados em Wang et al. (2008), Jin et al. (2010), Bentz et al. (2013), Guzman et al. (2014) e Savija et al. (2014).

Buscando representar de forma mais refinada a heterogeneidade estrutural do concreto, alguns autores procuraram investigar a difusividade distinta das várias fases que compõe esse material. Um dos principais argumentos recorrentemente apresentado é que considerar um único coeficiente de difusão para todo o concreto, obtido de forma teórica ou experimental, reproduz somente uma descrição média do processo de difusão de cloretos, sem nenhuma particularidade considerada.

Nesse sentido, Zeng (2007) utiliza um modelo bidimensional em elementos finitos para simular a difusão dos cloretos no interior do concreto considerando duas fases do material, cada uma com uma difusividade própria: pasta e agregados. Os resultados do modelo são comparados com os resultados obtidos considerando o material sendo homogêneo por meio da teoria do campo médio. Em contraste com o perfil suave de concentração de cloretos para o meio 
homogêneo, foi encontrado um perfil complicado e esparso de cloretos considerando-se o concreto sendo heterogêneo nas simulações. Além disso, os perfis de concentração de cloretos do modelo heterogêneo são ondulados e se estreitam à medida que a profundidade e o tempo de difusão aumentam. Outra diferença encontrada nos resultados é que o modelo heterogêneo aparentemente está defasado para trás em relação ao modelo homogêneo, apresentado um notável aumento da discrepância entre os perfis de concentração de cloretos conforme o avanço do processo difusivo. No entanto, tal discrepância pode ser notavelmente reduzida quando se assume que a ligação de cloretos e o efeito da redução da difusividade com o tempo ocorram na pasta de cimento para o modelo heterogêneo e no meio homogêneo também.

Outra pesquisa envolvendo a difusividade distinta das várias fases que compõe o concreto é apresentada por Wang et al. (2008). O concreto é simulado na meso escala como um compósito de três fases: partículas de agregados, argamassa e a zona interfacial de transição. O modelo de mola de corpo rígido (RBSM - Rigid Body Spring Model) é utilizado para prever o comportamento do concreto na presença de microfissuras. Além disso, o modelo de rede de treliça (Truss Network Model é adotado para avaliar a difusão de cloretos do concreto fissurado. Os resultados indicam que a difusividade de cloretos é significativamente dependente do nível de tensão, mas só considerar o efeito das fissuras previstas pelo modelo de mola de corpo rígido não é suficiente. Assim, uma equação empírica é proposta para levar em consideração a variação da microestrutura do concreto sob carregamento. Baseados em estudos prévios e dados experimentais, os autores propõem relações entre os coeficientes de difusão do concreto e da argamassa e a relação água/cimento. As simulações mostraram que acima de um certo nível crítico de tensão, o coeficiente de difusão de cloretos no concreto irá aumentar rapidamente, o que está de acordo com resultados experimentais. A vantagem do modelo de rede de treliça é sua simplicidade que torna possível realizar uma análise de difusão bidimensional utilizando uma equação unidimensional que governa o processo. O modelo de mola de corpo rígido é adotado em outros trabalhos como os de Bolander e Saito (1998), Nagai et al. (2004), Soda (2006) e Soda e Ueda (2006).

A respeito da relação e da sensibilidade entre os parâmetros que governam o tempo para início da corrosão, Zhang e Lounis (2006 e 2009) fizeram uma investigação nesse contexto baseados em um modelo simplificado de difusão baseado na primeira lei de Fick. Os parâmetros estudados foram o coeficiente de difusão de cloretos, o valor limite de cloretos nas armaduras, o cobrimento do concreto e a condição de exposição aos cloretos de superfície. Os autores concluem que: a) aumentar o cobrimento mínimo de concreto é mais efetivo que escolher um aço resistente a corrosão; b) é necessário usar tanto concretos de alta performance quanto aços 
resistentes a corrosão para que a vida útil da estrutura seja assegurada; c) uma redução relativa no concreto de cobrimento deve ser compensada por um aumento muito maior na resistência a corrosão do aço; d) as variações no coeficiente de difusão de cloretos têm um grande impacto no cobrimento de concreto requerido e no valor limite de cloretos, especialmente em ambientes cada vez mais agressivos. Apesar de tais conclusões serem importantes num estudo preliminar, o modelo adotado pelos autores desconsidera o efeito de ligação dos íons cloreto à matriz de cimento e considera a concentração de cloretos e o coeficiente de difusão constantes ao longo do tempo nas análises.

Com um apelo mais voltado a prática da engenharia corrente, Tapan e Aboutaha (2011) apresentam diagramas de interação carga axial versus momento fletor para vários níveis de corrosão observados nas armaduras e para várias configurações de perda de cobrimento (lascamento ou spalling) na seção transversal de pilares de concreto armado. Os autores utilizam diversos equacionamentos disponíveis na literatura para englobar o efeito da redução da tensão de escoamento das armaduras bem como a redução da aderência entre o aço e o concreto. Os resultados deste estudo sugerem que para pilares deteriorados a quantidade de resistência perdida depende da localização e da quantidade de degradação. A corrosão de barras de aço no lado comprido da seção do pilar reduz a altura útil e, portanto, causa maiores reduções do que deteriorações laterais ou no lado tracionado, em regiões de compressão controlada. Contudo, em geral, a corrosão de armaduras tracionadas causa maiores reduções na resistência que corrosões de armaduras comprimidas ou armaduras laterais, particularmente em regiões de tração controlada. A corrosão de todos os quatro lados da seção do pilar causa as mais significantes reduções de resistência, conforme esperado.

Existem também alguns softwares para a previsão da vida útil de estruturas de concreto armado submetidas a penetração de cloretos. Softwares contendo modelos de vida útil, como o Life-365 (PACK et al., 2010) e Stadium (SAMSON et al., 2007) têm sido utilizados para previsões de transporte de cloretos dependentes do tempo em concretos. Para o modelo Life-365, a dependência do tempo da concentração de cloretos de superfície é introduzida na solução da segunda lei de Fick e o coeficiente de difusão dependente do tempo, obtido por meio de uma técnica de médias no tempo, é aplicado a solução como uma variável para calcular o ingresso de cloretos. Para o modelo Stadium, o coeficiente de difusão é uma função dos parâmetros do material, como a porosidade e o conteúdo volumétrico de água (CAO et al., 2012).

Um estudo aplicado a dados ambientais reais para duas cidades brasileiras objetivando uma análise da vida útil, para diferentes cobrimentos de concreto, foi apresentado por Dominicini e Calmon (2017). Neste trabalho os autores utilizaram um modelo em elementos 
finitos proposto por Tavares (2013), baseado na solução da segunda lei de Fick, para a previsão do período de iniciação da corrosão. Os autores adotaram em suas análises, conforme descrito na literatura, diversas leis de evolução da concentração superficial de cloretos e para a variação do coeficiente de difusão. Este último parâmetro é analisado sob a influência dos efeitos da variação de temperatura, da radiação solar, da umidade relativa e do tempo de exposição (diretamente associado ao grau de hidratação). Os autores afirmam que a norma brasileira apresenta valores para a espessura de cobrimento que corroboram com os resultados obtidos pela simulação por eles feita de uma seção transversal de um elemento estrutural de concreto armado. Contudo, os autores afirmam que considerar ou não considerar cada fator interveniente no fenômeno da difusão pode levar a grandes alterações na definição do período de iniciação, a depender da condição da estrutura - localização, parâmetros climáticos, concentração superficial, tipo de cimento utilizado, etc. Ou seja, a importância de cada parâmetro não é constante, mas irá depender do caso específico e a adoção de modelos inadequados pode levar a grandes erros na previsão do tempo de iniciação da corrosão. Assim sendo, uma possível estratégia seria introduzir no problema as incertezas presentes nos parâmetros de análise e assim realizar uma análise de confiabilidade do elemento estrutural em questão.

\subsubsection{Estudos experimentais}

A pesquisa experimental é uma maneira bastante apropriada de se investigar fenômenos, sendo possível tirar conclusões e estabelecer se um ou mais fatores causam uma mudança em um resultado. É um tipo básico, direto e eficiente de pesquisa, podendo ser aplicado em diversas áreas do conhecimento.

Esse tipo de abordagem investigativa possui a vantagem de ser repetível, assim os resultados podem ser verificados e checados quando necessário. Outro ponto forte da pesquisa experimental deve-se ao ambiente controlado proporcionado, tendo-se normalmente um maior domínio sobre boa parte das variáveis envolvidas. Por exemplo, em um laboratório podem ser criadas condições não encontradas em um ambiente natural, limitando a influência de variáveis, a priori, desconhecidas. As consequências disso são resultados normalmente mais precisos e válidos. Além disso, fenômenos e condições que podem levar bastante tempo para ocorrer em um ambiente natural podem ser criados mais rapidamente em um contexto experimental.

Contudo, pesquisas experimentais podem criar situações artificiais que nem sempre reproduzem condições de ambientes naturais da vida real. Variáveis desconsideradas, por escolha ou por desconhecimento do pesquisador, numa reprodução em ambiente experimental podem ter na realidade uma grande influência numa situação em condições naturais. Outra desvantagem 
dessa abordagem relaciona-se à influência do erro humano na validade dos resultados. A integridade do experimento pode ser comprometida involuntariamente pelos pesquisadores que o estão realizando, influenciando os resultados finais e tornando as conclusões fictícias. Além disso, os resultados e conclusões experimentais podem ser muito específicos, não sendo possível por vezes a sua generalização.

A ciência é baseada em evidências experimentais, criticismo e discussão racional. O experimento conduz ao conhecimento do mundo físico e é o experimento que proporciona a evidência que fundamenta aquele conhecimento. Uma importante meta da ciência são teorias corretas. A teoria pode também orientar a experimentação e ajudar na validação dos resultados. Todavia, experimentos podem propiciar boas razões para acreditar em teorias. A experimentação desempenha diversos papéis na ciência. Um desses papéis é o de testar teorias e fornecer a base do conhecimento científico. Um experimento pode requerer uma nova teoria, seja mostrando que uma teoria já aceita é incorreta ou mostrando um novo fenômeno que necessita ser explicado. Além disso, a experimentação pode dar pistas em direção a estrutura ou a forma matemática de uma teoria e pode fornecer evidências da existência das entidades envolvidas. Finalmente, a experimentação pode medir quantidades que a teoria considera importante (FRANKLIN, 2007).

Especificamente nas pesquisas experimentais relacionadas à corrosão de estruturas de concreto armado acarretadas por íons cloreto, são investigados os seguintes pontos: determinação do valor do coeficiente de difusão e da concentração superficial de cloretos, influência da composição do concreto na difusão, influência da presença de fissuras na difusão, tempo e localização espacial da iniciação da corrosão, influência das condições ambientais no período de iniciação e propagação da corrosão, influência do processo de cura, capacidade resistente residual de elementos de concreto armado corroídos, entre outros. Apesar do presente trabalho não utilizar uma abordagem experimental, os resultados de tais estudos expandem fortemente a compreensão do fenômeno da difusão de cloretos e corrosão de armaduras em concreto armado.

Além da realização de ensaios mecânicos usuais na engenharia de estruturas, ensaios específicos relacionados aos fenômenos corrosivos podem ser feitos em corpos de prova de concreto, nas barras de aço e em elementos/estruturas de concreto armado. Entre os ensaios mais usuais pode-se citar o teste de migração rápida, o teste rápido de permeabilidade de cloretos, o teste acelerado de nível limite de cloretos e o teste rápido de macro célula. Stanish et al. (1997) apresentam uma tabela contendo os principais testes de resistência a penetração de cloretos no concreto. A tabela diferencia os testes quanto a sua duração, consideração do movimento de íons 
cloreto, variação de temperatura, entre outros pontos. Desde então as metodologias de testes avançaram e se desenvolveram.

Existem dois tipos de experimentos de penetração natural, geralmente utilizados para mensurar os coeficientes de difusão de cloretos no concreto. O primeiro é o teste de difusão estacionário, como por exemplo o teste de célula de difusão, onde o corpo de prova de concreto é usado para separar uma solução com cloretos de uma solução com cloretos livres, sendo feitas medições periódicas do conteúdo de íons cloreto até se alcançar uma condição estacionária. $\mathrm{O}$ segundo tipo de teste é feito para estados de difusão não estacionários, envolvendo a imersão do corpo de prova de concreto por um tempo especifico antes de medir o perfil ou a profundidade de penetração de cloretos, como o teste de imersão em sal (SAVAS, 1999). Testes de penetração natural levam normalmente muito tempo, especialmente para medir a difusividade de cloretos em concretos de alto desempenho. Os testes de difusão levam normalmente de um a três anos de exposição em um ambiente controlado (HUSAIN et al., 2004). Uma forma de acelerar o ingresso de cloretos no concreto é aplicando um campo de pressão, como por exemplo expondo uma face do concreto a uma solução de cloretos sob pressão, o que acaba conduzindo os cloretos dentro do concreto tanto por um processo de difusão quanto por um de convecção. Contudo, essa metodologia não é muito utilizada nem pesquisada (SHI et al., 2010).

Nas últimas décadas, testes de migração em campos elétricos se tornaram populares pois podem acelerar muito o processo de ingresso de cloretos no concreto. O teste de migração rápida é um método para medir a migração elétrica de cloretos de um compartimento com uma solução de cloretos para outro sem cloretos (STANISH et al., 2004). O teste rápido de permeabilidade de cloretos é um método que registra a quantidade de carga que passa através de uma amostra de concreto com o objetivo de avaliar sua permeabilidade (AHMED et al., 2009). Contudo, o teste rápido de permeabilidade de cloretos não é adequado para avaliar a permeabilidade de concretos contendo materiais suplementares ao cimento, uma vez que os resultados podem ser tendenciosos devido a uma mudança na composição química intersticial dos poros do concreto (SHI et al., 1998; FELDMAN et al., 1999; ANDRADE et al., 2000; WEE et al., 2000).

O teste de migração acelerada de cloretos pode ser considerado a versão modificada do teste de migração rápida e do teste rápido de permeabilidade de cloretos, onde é medida periodicamente a concentração de cloretos acumulada tanto pelo método da titulação potenciométrica (CHO e CHIANG, 2006) ou utilizando um sensor de cloretos (HE e SHI, 2008; YANG et al., 2009). O teste dura até que uma concentração significativa de cloretos é detectada, o que pode levar até semanas dependendo da espessura e da qualidade do corpo de prova e da voltagem aplicada. Cho e Chiang (2006) investigaram a difusividade de corpos de prova de 
concreto com várias relações água/cimento e com substituição parcial de escória de alto forno. Os autores reportaram uma boa correlação entre a carga de passagem e o coeficiente de difusão não estacionário obtido em testes de imersão. Já para concretos sem adição de escórias, a correlação foi ruim. Para ambos os tipos de concreto, observou-se uma correlação linear entre o coeficiente de difusão estacionário, obtido pelo teste de migração acelerada de cloretos, e o coeficiente de difusão não estacionário, obtido pelo teste de imersão, o que sugere que o teste de migração acelerada de cloretos é um método confiável.

O teste acelerado de nível limite de cloretos é utilizado para determinar o nível crítico de cloretos nas armaduras de aço embutidas no concreto. Sob uma constante diferença de potencial, que é aplicada a cada seis horas, os íons cloreto migram de uma solução de cloretos colocada na superfície do concreto para a superfície da armadura de aço. A iniciação da corrosão é monitorada através de medidas de resistência de polarização. A aplicação do potencial é interrompida quando as resistências de polarização medidas indicarem a iniciação da corrosão. Amostras são então separadas e a concentração de cloretos na superfície do aço são determinadas (TREJO et al., 2009).

O teste rápido de macro célula mede a taxa de corrosão e o potencial de meia célula do aço das armaduras embutidas no concreto. Corpos de prova de armaduras de aço cobertos com uma camada fina de argamassa são colocados em recipientes separados para agir como cátodos e ânodos. O recipiente com o cátodo contém dois corpos de prova para aumentar a razão de superfície entre cátodo e ânodo. O recipiente com o cátodo é preenchido com uma solução que simula o concreto e é limpo com ar limpo. O recipiente com o ânodo é preenchido com uma solução que simula o concreto e uma solução salina. Os corpos de prova agindo como cátodos e ânodos são conectados com um resistor e os recipientes são conectados com uma ponte de sal para fechar o circuito. A corrosão é então determinada medindo-se a corrente que flui através do resistor e com as medidas do potencial de meia célula (TREJO et al., 2009).

A maior parte dos ensaios relacionados aos processos de difusão e corrosão de armaduras em concreto encontram-se normatizados. Contudo, a grande maioria dos procedimentos encontram-se em normas estrangeiras, estando as diretrizes nacionais brasileiras bastante limitas nesse aspecto atualmente.

Um importante fator influenciador no processo difusivo é a composição do concreto. Quão mais compacta e densa for a microestrutura do concreto, maior dificuldade apresentará para a passagem de agentes agressivos e, portanto, maior será a vida útil do material. Outro ponto a ser observado é a facilidade com que os componentes do concreto possuem em ligar-se quimicamente com os íons cloreto, impedindo-os de reagirem com as armaduras de aço no 
interior do concreto. Dentre os fatores que influenciam a capacidade e ligação dos cloretos podese destacar o conteúdo de aluminato tricálcico e outros componentes alcalinos, uso de aditivos minerais, temperatura, grau de hidratação e a quantidade total de cloretos (PAGE e VENNESLAND, 1983; HOLDEN et al., 1983; BYFORS, 1986; ARYA et al., 1990; NAGATAKI et al., 1993; ARYA e XU, 1995; KAYYALI e HAQUE, 1995; DHIR et al., 1997; WIENS e SCHIESSL, 1997; BUENFELD et al., 1998; LARSEN, 1998; LU et al., 2002; LUO et al., 2003; CHENG et al., 2005). Em geral, uma baixa relação água/cimento e a utilização de cinzas volantes, escórias de alto forno, sílica ativa ou metacaulim promovem uma melhoria na durabilidade do concreto nesse aspecto.

A cinza volante é um subproduto da combustão de carvão na geração de eletricidade, sendo um resíduo finamente segregado capturado do gás de combustão em usinas termoelétricas a carvão. É composto essencialmente por dióxido de silício e óxido de cálcio. As substituições por cinzas volantes na composição de concretos é algo normalmente em torno de 15\% a 50\% no cimento CP IV e de 6\% a 14\% no cimento CP II-E. Dhir et al. (1997) mostram que a capacidade de ligação de cloretos à pasta de cimento aumenta com um aumento da substituição por cinzas volantes até um nível de 50\%. Ampadu et al. (1999) apresentam em seu trabalho que a substituição parcial de cimento por cinzas volantes só mostrou benefícios notáveis na redução da difusividade de cloretos na pasta de cimento em idades mais avançadas de cura e que com uma substituição de 40\% alcançaram-se os melhores resultados. Wong et al. (1999) testaram amostras de argamassa e concluíram que uma substituição de cimento de 15\% por cinzas volantes aumentou a aderência na interface entre agregado e argamassa e a tenacidade a fratura. Em altos níveis de substituição (45\% e 55\%), a adição de cinzas volantes reduziu a resistência de aderência interfacial e a tenacidade à fratura em 28 dias, mas essas reduções foram recuperadas em 90 dias. Verificou-se que a substituição de cinzas volantes em todos os percentuais aumentou a energia de fratura interfacial. Hossain et al. (2008) investigaram o efeito da incorporação de cinzas volantes ultrafinas no concreto e compararam com os efeitos verificados com a adição de cinzas volantes usuais. Por possuir uma estrutura mais fina e consequentemente reduzindo ainda mais a porosidade, essa adição apresentou uma melhoria na resistência do concreto, uma menor retração, uma diminuição na fissuração e nos efeitos de fluência. Parande et al. (2011) reportaram que concretos feitos com cimento Portland pozolânico com cinzas volantes alcançaram maiores resistências a compressão aos 150 dias, menor permeabilidade a cloretos, menor corrosão das barras em água normal e em água de esgoto doméstico em relação a concretos feitos com cimento Portland comum. Em geral as pesquisas feitas a respeito da utilização de cinzas volantes reportam que o coeficiente de difusão do concreto em idades precoces não é reduzido em 
comparação com a utilização do concreto feito com cimento Portland comum (MANGAT e MOLLOY, 1994; THOMAS e BAMFORTH, 1999; THOMAS et al., 1999; PAPADAKIS, 2000; BASHEER et al., 2002; THOMAS e MATTHEWS, 2004). Contudo, em idades mais avançadas, a adição de cinzas volantes promove uma redução do coeficiente de difusão. Outros trabalhos relacionados a utilização de cinzas volantes no concreto são atribuídos a Gebler e Klieger (1986), Hedegaard e Hansen (1992), Thomas (1996), Schiessl e Breit (1996), Bouzoubaa et al. (2001), Alonso et al. (2002), Oh et al. (2003), Saraswathy e Song (2006) e Pacheco-Torgal e Jalali (2009).

As escórias de alto forno são um outro material cimentício suplementar bastante pesquisado com enfoque em suas propriedades de aumento de durabilidade do concreto. As escórias são um subproduto da produção de aço e ferro, possuindo em sua composição principalmente óxido de cálcio, óxido de silício, óxido de alumínio e óxido de magnésio. As substituições por escórias de alto forno na composição de concretos é algo normalmente em torno de $40 \%$ a $80 \%$. Khatib e Hibbert (2005) observaram que para substituições parciais de até $80 \%$ desse material a resistência a compressão do concreto é reduzida nos primeiros 28 dias de vida, mas que em idades mais avançadas a resistência aumenta com substituições de até $60 \%$. A escória de alto forno melhora consideravelmente a estrutura porosa do concreto, aumentando a capacidade ligação de cloretos (formando mais sal de Friedel) e reduzindo a difusividade (ALGAHTANI et al., 1994; LUO et al., 2003; CHENG et al., 2005). Preez e Alexander (2004) observaram que concretos contendo escória de alto forno possuem um desempenho superior com relação a difusividade de cloretos aos 28 dias, enquanto que concretos contendo cinzas volantes inicialmente possuem condutividades maiores de cloretos aos 28 dias. Yang e Wang (2004) apresentam os resultados de uma pesquisa envolvendo ensaios com corpos de prova de concreto, contendo cinzas volantes ou escórias de alto forno em sua composição, imersos em soluções salinas com testes de migração acelerada de cloretos. Os resultados mostraram que o coeficiente de difusão diminuiu significativamente devido a uma melhoria da estrutura de poros do material. Os autores reportam também uma redução no coeficiente de difusão com uma diminuição da relação água/cimento. Contudo, a condutividade de cloretos diminui também para concretos com cinzas volantes com o passar do tempo, sendo que os resultados alcançados aos 120 dias são indistinguíveis dos resultados alcançados por concretos contendo escória de alto forno. Tal comportamento pode ser explicado pela menor taxa de reação da cinza volante. Contudo, o efeito da substituição parcial por escórias de alto forno no valor limite de cloretos para a iniciação da corrosão é ainda controverso. Dhir et al. (2000) reportaram baixos valores limite de cloretos enquanto que Schiessl e Breit (1996) e Oh et al. (2003) reportaram valores iguais ou maiores respectivamente quando o cimento é substituído pelas escórias. De maneira 
geral, a escória presente no concreto reage com a água e com a pasta de cimento hidratada, resultando em uma microestrutura mais fina do que àquela obtida com o concreto de cimento Portland comum. Em idades precoces, o concreto contento escórias terá um coeficiente de difusão igual ou maior do que aquele em concretos contendo cimento Portland comum, mas em idades superiores a 90 dias, terá um coeficiente de difusão menor. As melhores reduções do coeficiente de difusão de cloretos são para um nível de substituição desse material a partir de 40\% (GOUDA, 1970; MANGAT e MOLLOY, 1994; THOMAS et al., 1999 e 2008; THOMAS e BAMFORTH, 1999; BASHEER et al., 2002; BLESZYNSKI et al., 2002; LUO et al., 2003; SELEEM et al., 2010; HADJ-SADOK et al., 2011).

A silica ativa por sua vez é um subproduto da manufatura de ligas de silício em fornos elétricos a arco. A sílica ativa é um material pulverulento ultrafino, com suas partículas medindo entre $0,1 \mu \mathrm{m}$ e $0,5 \mu \mathrm{m}$, aproximadamente cem vezes mais fino que os grãos de cimento, sendo composta quase que inteiramente de dióxido de silício. As substituições por sílica ativa na composição de concretos são algo normalmente em torno de 3\% a 10\%. Até 10\% de substituição a trabalhabilidade do concreto fresco não é reduzida, porém reduções no seu abatimento (slump) foram observadas para baixas relações água/cimento (DUVAL e KADRI, 1998). Nesses casos frequentemente se usa um superplastificante junto da adição de sílica ativa, reduzindo a necessidade de acrescentar água para atingir-se uma adequada trabalhabilidade. Malhotra (1993) relata que o coeficiente de difusão de pastas de cimento contendo uma adição de sílica ativa foi quatro vezes menor do que para pastas sem essa adição. Bentz $\left(2000^{2}\right)$ reporta que o coeficiente de difusão de concretos é 15 vezes menor com 10\% de substituição por sílica ativa comparativamente com o concreto comum. A avaliação do efeito das propriedades difusivas do concreto a partir da incorporação de sílica ativa e de cinzas volantes foi realizada por Papadakis (2000). O autor concluiu que a incorporação de materiais cimentícios complementares no concreto diminui o conteúdo total de cloretos em todas as profundidades, com exceção de uma fina camada próxima a superfície. Esse resultado mostra uma redução no coeficiente de difusão do concreto. Dotto et al. (2004) observaram que a adição de sílica ativa conduz a melhorias significativas na prevenção a corrosão, assim como uma melhoria na resistência a compressão do concreto. Song et al. (2010) investigaram a microestrutura da sílica ativa empregada junto ao cimento no concreto. Os autores sugerem que a finura da sílica ativa afeta notavelmente a permeabilidade do concreto, sendo a faixa de substituição recomendada desse material entre $8 \%$ e $12 \%$ da massa de aglutinante. Page e Vennesland (1983) e Selvaraj et al. (2003) estudaram a influência da sílica ativa na corrosão de armaduras no concreto, incluindo a difusão de cloretos, carbonatação, difusão de oxigênio, $\mathrm{pH}$ da solução nos poros e resistividade elétrica do concreto. 
Substituições parciais do cimento por esse material indicam uma redução na alcalinidade da solução nos poros e na capacidade de ligação de cloretos da pasta de cimento endurecida. Byfors (1987) explica que a redução do pH se deve principalmente à reação pozolânica entre o óxido de silício e o hidróxido de cálcio. Já a redução na capacidade de ligação de cloretos é explicada pela redução da quantidade de aluminatos no concreto que são capazes de prender quimicamente os cloretos (PAGE e VENNESLAND, 1983; ARYA et al., 1990; LARSEN, 1998; FARMANI et al., 2015). De uma forma geral, a sílica ativa é reconhecida por reduzir consideravelmente a permeabilidade do concreto e por reagir rapidamente devido, respectivamente, ao tamanho pequeno e à grande área de superfície de suas partículas (MANGAT e MOLLOY, 1994; THOMAS et al., 1999; BENTZ, 2000 ; PAPADAKIS, 2000; SMITH, 2001; BLESZYNSKI et al., 2002; SELEEM et al., 2010).

O metacaulim é um geopolímero pozolânico constituído basicamente de sílica e alumina na fase amorfa. É um material obtido a partir da desidroxilização da caulinita feita em um forno com queima externa entre 500 e $800^{\circ} \mathrm{C}$. Possui partículas de tamanho entre $1 \mu \mathrm{m}$ e $2 \mu \mathrm{m}$, o que lhe confere uma área de superfície maior se comparado com o cimento Portland usual, porém possui partículas maiores do que àquelas da sílica ativa. O metacaulim reage com o hidróxido de cálcio gerado durante a fase de hidratação do cimento Portland, formando produtos hidratados similares aos decorrentes da hidratação direta do clínquer Portland, sendo de alta eficácia para concretos e produtos à base de cimento Portland. O metacaulim acelera o processo de hidratação do cimento, formando silicato de cálcio hidratado adicional. Devido ao tamanho pequeno de suas partículas e a alta área de superfície, o metacaulim reage rapidamente e reduz o coeficiente de difusão se comparado com o cimento Portland comum. As substituições por metacaulim na composição de concretos é algo normalmente em torno de 5\% a 10\% (GRUBER et al., 2001; BASHEER et al., 2002; BATIS et al., 2005; SELEEM et al., 2010; HOLLAND et al., 2016). Asbridge et al. (2001) apresentam resultados de testes de difusão estacionária e não estacionária de cloretos em concretos contendo metacaulim. Dentre as conclusões os autores afirmam que a resistência ao transporte de cloretos é reduzida por meio da hidratação da matriz de cimento e da zona de transição interfacial entre a pasta e os agregados. Abdul Razak et al. (2004) realizaram testes de absorção superficial inicial e absorção de água em corpos de prova de concreto contendo metacaulim e sílica ativa. A cura foi feita em diferentes condições por períodos de 7 a 90 dias. Os resultados indicaram que, com uma substituição de $10 \%$ do cimento por metacaulim ou sílica ativa, a capacidade de absorção superficial do concreto foi reduzida. A substituição de cimento ou areia por metacaulim ( $10 \%$ ou $20 \%$ do peso de cimento) pode reduzir fortemente a permeabilidade a cloretos, a gás e a capacidade de absorção do concreto, reduzindo o tamanho 
médio dos poros e melhorando a uniformidade de distribuição dos poros (BADOGIANNIS e TSIVILIS, 2009). Shekarchi et al. (2010) reportam que uma substituição de $15 \%$ de metacaulim conduziu a um aumento de $20 \%$ na resistência a compressão do concreto endurecido e uma redução em sua penetração a água, absorção de água, permeabilidade a gases, condutividade elétrica e difusão iônica.

Resumindo, o conteúdo de cimento tem uma pequena influência na difusão de cloretos em concretos feitos com relações água/cimento parecidas. O coeficiente de difusão aumenta com um aumento da relação água/cimento. Dessa forma, a porosidade do concreto é um fator determinante para o processo de difusão. A temperatura tem um efeito complexo na difusão de cloretos. Um aumento na temperatura de exposição aumenta tanto a difusividade iônica quanto a capacidade de ligação de cloretos. Além disso, temperaturas elevadas aceleram as reações pozolânicas e de hidratação do cimento, porém causam o aparecimento de microfissuras na interface matriz/agregado. O efeito combinado de altas temperaturas de exposição em concretos compostos por cimento Portland simples é um aumento da transmissão de cloretos enquanto que o oposto é verdadeiro para concretos compostos por cimento contendo cinzas volantes. Geralmente, concretos contendo cinzas volantes ou escórias de alto forno possuem um menor coeficiente de difusão do que concretos contendo somente cimento Portland comum. Em alguns casos, concretos com cinzas volantes inicialmente tem um maior coeficiente de difusão do que concretos simples, porém isso é revertido com o passar do tempo (BIOUBAKHSH, 2011).

Para que o material concreto possua um bom desempenho ao longo de sua vida útil são necessários alguns outros cuidados, especialmente ligados ao processo de cura. Uma cura não adequada pode resultar em redução da resistência prevista, acarretando fissuras excessivas e facilitando a entrada de substâncias agressivas. Existem diversos tipos de cura como a úmida, química, ao ar e a térmica. A relação entre a cura do concreto e sua difusividade foi investigada por diversos autores.

Ramezanianpour e Malhotra (1995) utilizaram o método ASTM C 1202 para avaliar a resistência à penetração de íons cloreto em corpos de prova de concreto submetidos a processos de cura úmida, térmica, e úmida e térmica combinadas. As curas corresponderam a períodos de 7 , 28 e 180 dias. Os resultados mostraram que concretos que não foram curados de nenhuma forma após o desmolde apresentaram desempenhos piores. Concretos curados por apenas dois dias apresentaram desempenhos significativamente melhores do que concretos que não receberam nenhuma cura.

Abouhussien e Hassan (2014) apresentam um trabalho onde avaliam, empiricamente e experimentalmente, o tempo total de corrosão no concreto armado considerando três estágios: 
iniciação da corrosão, período de danificação e fissuração. As amostras de concreto armado testadas foram submetidas a dez diferentes técnicas de cura (ao ar livre e submersas em água), incluindo temperaturas quentes, frias e normais antes do teste. A iniciação da corrosão, fissuração e o período de danificação na investigação foram experimentalmente monitorados por meio de testes de corrosão acelerada. De maneira geral, segundo os autores, a tendência dos resultados dos períodos de iniciação da corrosão obtidos a partir dos testes acelerados de corrosão é similar àquela obtida a partir da segunda lei de difusão de Fick. A cura para um período de 28 dias (a $23^{\circ} \mathrm{C}$ ) se mostrou o melhor sistema de cura (comparado com curas feitas ao ar livre, frias e quentes) em termos de resistência a compressão, permeabilidade de cloretos e resistência a corrosão. As amostras curadas em água tiveram os maiores tempos para demonstrar sinais de iniciação de corrosão, fissuração e danificação entre as amostras testadas. Por outro lado, entre todas as amostras testadas, as primeiras amostras que apresentaram iniciação da corrosão, fissuração e danificação foram aquelas curadas em água quente por 7 dias a $50^{\circ} \mathrm{C}$. Os autores adotaram o mesmo traço para todos os corpos de prova, não estudando a influência da composição do concreto. Na pesquisa variou-se apenas a espessura do cobrimento $(20,30,40,50$ e $60 \mathrm{~mm}$ ) e as condições de cura: disponibilidade de água (no ar ou submerso na água) e a temperatura (frio, normal e quente, 3, 23 e 50 graus respectivamente). Apesar deste tipo de investigação mostrar claramente os diversos estágios do processo corrosivo, a aplicação e interpretação da segunda lei de Fick e a influência da variação de diversas condições de cura, existem certas limitações que devem ser observadas. Alguns autores argumentam que testes de corrosão acelerada não são adequadamente representativos para a previsão do tempo de iniciação de corrosão de estruturas reais de concreto armado (AUYEUNG et al., 2000; CASTEL et al., 2000ª; EL MAADDAWY e SOUDKI, 2003; AUSTIN et al., 2004; VIDAL et al., 2007; YUAN et al., 2007). O fenômeno ocorre na realidade com uma taxa de corrosão não constante com o tempo e também aleatoriamente distribuída ao longo da estrutura.

A cura úmida é essencial para que o concreto atinja um menor nível de penetração à cloretos. O efeito de curas malfeitas na difusividade do concreto é mais severo para concretos feitos com materiais suplementares. Escórias de alto forno e cinzas volantes são muito sensíveis ao regime de cura, sendo que práticas ruins de cura podem afetar suas propriedades (BIOUBAKHSH, 2011).

Foi verificado que o coeficiente de difusão é também dependente do tempo para concretos expostos a ambientes com ciclos de molhagem/secagem incluindo estruturas marinhas e em ambiente rodoviário. Tang e Nilsson (1992), a partir de testes de difusividade rápida, concluíram que o coeficiente de difusão em concretos jovens diminui drasticamente com a idade. 
A partir das observações feitas, os autores propuseram que a diminuição do coeficiente de difusão se daria por uma lei exponencial e diretamente relacionada a um fator de idade. Autores como Tang e Nilsson (1992), Mangat e Molloy (1994), Boddy et al. (1999), Thomas e Bamforth (1999), Stanish e Bamforth (2003), Bamforth (2004), Nokken et al. (2006) e Audenaert et al. (2010) buscaram descobrir esses fatores de idade em função do tempo de existência e do tipo de cimento utilizado no concreto.

Tang e Gulikers (2007) argumentam, referindo-se a trabalhos como os de Mangat e Molloy (1994) e Maage et al. (1995), que utilizar o coeficiente de difusão dependente do tempo diretamente na função erro que aparece a partir da solução clássica da equação que define a lei de Fick é matematicamente incorreto, uma vez que tal solução considera o coeficiente de difusão constante no tempo. Proceder de tal forma pode subestimar o ingresso de cloretos em alguns casos, conforme demonstrado pelos autores. O coeficiente de difusão dependente do tempo não pode ser utilizado diretamente dentro da função erro sem realizar-se uma integração no tempo.

Com o objetivo de determinar a relação entre o coeficiente de difusão e o tamanho de abertura de fissuras no concreto, vários autores realizaram estudos empíricos. Uma curva de ajuste é traçada para interpolar a nuvem de pontos obtida a partir dos ensaios realizados. Contudo, observa-se uma grande discrepância nos dados experimentais. Essa discrepância pode ser explicada considerando dois principais pontos. Em primeiro lugar, os valores reportados dos coeficientes de difusão nas fissuras apresentam uma enorme diferença. Por exemplo, para um mesmo tamanho de abertura de fissura nos estudos apresentados por Kato et al. (2005), Sahmaran (2007), Djerbi et al. (2008) e Sillanpää (2010), o coeficiente de difusão obtido variou entre dez e dez mil vezes. Em segundo lugar, o tamanho limite da largura de abertura de fissura (acima do qual a difusão de cloretos começa a ser influenciada significativamente pela fissuração) também é muito variável. As enormes diferenças reportadas nos coeficientes de difusão obtidos provém de várias fontes, como o ambiente do experimento, defeitos nos métodos de ensaio, erros de manipulação, erros de ensaio, diferentes características dos concretos utilizados (porosidade inicial e umidade), etc. Especialmente por essas razões, ainda não existe um modelo matemático unificado e razoável para descrever os efeitos das fissuras no processo difusivo no concreto quantitativamente (JANG et al., 2011).

Investigando o transporte de cloretos em 11 pontes de concreto, com idades de até quase 50 anos, localizadas em ambiente marinho na costa oeste da Coréia do Sul, Pack et al. (2010) descrevem que o coeficiente de difusão, obtido por meio de ensaios realizados em corpos de prova extraídos dos pilares das pontes, decresceu exponencialmente com o tempo e que a concentração superficial de cloretos cresceu conforme uma função logarítmica em função do 
tempo. Usando as informações obtidas, equações são propostas para a variação do coeficiente de difusão e para a concentração superficial de cloretos para longos períodos de tempo. O modelo dependente do tempo indicou um maior ingresso de cloretos em concretos feitos com cimento Portland simples do que o modelo independente do tempo. Isto se deve ao fato de que há um acúmulo da concentração de cloretos de superfície com o tempo. Já para concretos contendo escória de alto forno em sua composição o resultado entre o modelo dependente e independente do tempo foi similar em relação a quantidade de ingresso de cloretos devido ao rápido decrescimento do coeficiente de difusão. Os autores comparam os seus resultados com o do software Life-365. O modelo proposto no estudo apresentou uma boa previsão da taxa de transporte de cloretos, enquanto que o modelo do software descreveu de forma imprecisa o ingresso de cloretos para longos períodos de tempo, devido ao fato deste último modelo considerar um valor constante para a concentração superficial de cloretos e também superestimar o decréscimo do coeficiente de difusão.

Um dos poucos trabalhos experimentais reportados na literatura investigando os efeitos da densidade de fissuras no transporte de cloretos em concretos fissurados foi feito apresentado por Mu et al. (2013). O estudo investiga a difusão não estacionária em amostras de concreto com diferentes densidades de fissuras, preparadas por meio de um método de entalhe não destrutivo. Os autores explicam que a água e o conteúdo de cloretos solúveis aumentam significativamente com o aumento da densidade de fissuras até um certo valor. É apresentada uma função linear que descreve a relação entre o coeficiente de difusão (determinado pelos cloretos solúveis em ácido) e a densidade de fissuras. Uma função por partes incluindo uma função linear e uma exponencial é também proposta no trabalho para descrever a relação entre o coeficiente de difusão (determinado pelos cloretos solúveis em água) e a densidade de fissuras.

Com uma técnica bastante refinada para a medição da concentração de cloretos, Angst e Polder (2014) apresentam dados experimentais da distribuição espacial de cloretos em concretos não fissurados sujeitos a exposições homogêneas. As concentrações de cloretos foram medidas com sensores potenciométricos embutidos no concreto exposto ao ingresso de cloretos por meio de ciclos de molhagem e secagem. Os sensores permitiram uma medição altamente localizada e não destrutiva. $\mathrm{Na}$ pesquisa foram utilizados seis diferentes traços de concreto, cada um com mais de vinte sensores embutidos dentro de um plano de profundidade constante. Os autores concluem que a variabilidade espacial de cloretos observada é uma real propriedade da penetração de cloretos no concreto e não uma incerteza que surge da precisão de medidas limitadas. A causa primária foi identificada como sendo a presença de agregados graúdos ao invés do que a relação água/cimento, tipo de cimento e condições de exposição. Os agregados graúdos 
introduzem uma variável de tortuosidade nos poros, aumentando a aleatoriedade do processo. Estudos desta natureza são importantíssimos para distinguir a real natureza das incertezas presentes no problema, sejam elas incertezas do fenômeno, experimentais ou de outro tipo. Tais distinções são fundamentais, especialmente na modelagem computacional da previsão de vida útil de estruturas com abordagens probabilísticas, uma vez que se busca apenas simular as incertezas do fenômeno, deixando de lado as incertezas de medição inerentes à um procedimento experimental.

Fu et al. (2015), a partir de análises teóricas e experimentais, propõem um modelo de difusão de cloretos baseado na segunda lei de Fick modificada com ênfase nos efeitos dos carregamentos mecânicos. Em particular, essa influência é quantificada utilizando um novo fator de dano definido pela tortuosidade e constrictividade do concreto danificado. $\mathrm{Na}$ parte experimental dois tipos de traços (concreto comum e concreto com escórias) são estudados realizando-se testes de difusão de cloretos em distintos estados de tensão (compressão e tração) e de magnitude de carregamento. No total foram aplicados quatro níveis de carregamento para correlacionar a difusividade dos cloretos com os valores de deformação associados. Os autores concluem que a difusividade de cloretos em concretos saturados submetidos a carregamentos de flexão é refletida pelas deformações locais e não no geral pelas cargas aplicadas. Consequentemente, a fim de investigar os efeitos de carregamento na difusão de cloretos no concreto, um método baseado em deformações é mais confiável que um método baseado em carregamento. A difusividade de cloretos aumenta com o aumento da deformação de tração. $\mathrm{O}$ dano gerado no concreto acelera a taxa de aumento de difusividade. Do contrário, a difusividade de cloretos é reduzida com o aumento da deformação de compressão dentro de um intervalo limite. Contudo, os autores investigaram as modificações no processo difusivo apenas até a carga que dá o início da fissuração do concreto. Assim, não englobam no estudo as variações que a fissuração provoca nos mecanismos de transporte de cloretos no concreto.

Uma análise em campo da distribuição vertical da salinidade marinha em áreas costeiras brasileiras é realizada por Meira et al. (2017). Enfoque especial é dado para a influência da velocidade do vento no acúmulo de cloretos na superfície do concreto. A cidade em estudo foi João Pessoa na Paraíba. Os resultados do estudo mostram que a taxa de deposição de cloretos nas velas úmidas, utilizadas em campo, decresce drasticamente quando a altitude aumenta e essa relação pode ser representada por uma função de decaimento exponencial, que é influenciada pelo regime de vento. Os autores propõem um novo modelo para representar o fenômeno, sendo baseado na influência simultânea da altura a partir do solo (até 10 metros de altura) e da velocidade do vento (maior do que $3,0 \mathrm{~m} / \mathrm{s}$ ) ponderada pelo seu tempo de duração. Os autores 
concluem que o impacto da diminuição da salinidade com a altitude na acumulação de cloretos no concreto é significativo. Contudo no modelo proposto não se considera, por exemplo, a influência da temperatura ou da umidade relativa do ar na concentração de cloretos.

A integridade das barras de aço que compõem as armaduras é fundamental para garantir uma adequada resistência e principalmente a ductilidade dos elementos estruturais de concreto armado. A corrosão compromete gravemente essa integridade, causando diversos efeitos danosos. Neste sentido, algumas pesquisas foram realizadas com o objetivo de compreender melhor tais efeitos.

Pesquisas realizadas por Almusallam (2001), Lee et al. (2002), Cairns et al. (2005), Du et al. (2005 e 2005 $)$, Apostolopoulos et al. (2006), Apostolopoulos e Papadopoulos (2007), Apostolopoulos e Papadakis (2008) e Apostolopoulos e Kappatos (2013) investigaram a capacidade residual de barras corroídas. Os ensaios de tração foram realizados em barras com variados diâmetros, em barras nervuradas e lisas, submetidas a corrosão acelerada ou a assim dita corrosão artificial, aplicando-se um entalhe semicircular na barra com o objetivo de simular a redução da área de aço resultante do processo de corrosão. Devido ao ataque local por penetração e a concentração de tensões, as forças residuais de armaduras corroídas decrescem mais rapidamente do que suas seções transversais médias. Como resultado, a resistência residual de armaduras corroídas, medida em termos de tensões que podem ser resistidas, também decresce significativamente. Para uma mesma corrosão, a capacidade residual de armaduras corroídas nuas e de armaduras imersas em concreto são similares. Embora a capacidade residual de diâmetros menores e/ou de armaduras lisas diminua mais rapidamente que diâmetros maiores ou armaduras nervuradas, a influência do tipo e diâmetro da armadura são insignificantes, tendo um nível de significância de 5\% na maioria dos casos, podendo-se negligenciar na engenharia prática. Com base nos resultados experimentais, alguns desses autores propõem equações para a previsão da capacidade residual (tensão de escoamento) em função da taxa de corrosão, do tempo decorrido após a despassivação da barra e do diâmetro da barra sã (não corroída). Contudo, talvez a conclusão mais preocupante dos estudos seja com relação a alteração da ductilidade das barras. Com o aumento do nível de corrosão, a ductilidade vai reduzindo-se cada vez mais. Para um nível de corrosão de $16,3 \%$ a ductilidade foi reduzida em quase $70 \%$, tornando o comportamento à ruptura do material quase como sendo frágil.

Cabem aqui alguns pontos a serem comentados a respeito desse assunto. A maioria dos estudos utiliza métodos de corrosão acelerada ou por meio de defeitos mecânicos (entalhes) introduzidos diretamente sobre as barras testadas. Contudo, essas situações não refletem uma condição real de corrosão em ambiente natural. A penetração de cloretos resulta normalmente 
em uma corrosão por pites (localizada), enquanto que testes de corrosão acelerada normalmente resultam em barras com corrosão uniforme.

Além disso, a seção transversal residual ou a perda da seção transversal das barras de aço corroídas foi feita por meio de diferentes medidas. Alguns experimentos obtiveram medidas diretamente a partir de leituras em paquímetros. Essa forma de medição pode ter subestimado a redução da seção transversal e ter resultado em uma resistência calculada maior do que a resistência verdadeira. Outros experimentos utilizaram a drenagem para medir o volume residual das barras corroídas. Contudo, como a superfície das barras corroídas era bastante irregular e muitos micro poros existiam ao longo da superfície, isso aumentou a possibilidade de que o ar permanecesse nos micro poros quando as barras foram imersas na água. Como resultado, o volume das barras residuais pode ter sido superestimado e a resistência das barras corroídas pode ter sido subestimado consequentemente (ZHU, 2014).

Apesar de autores como Tapan e Aboutaha (2011) afirmarem que as equações propostas para a avaliação da capacidade residual de barras corroídas estarem de acordo com resultados obtidos para barras corroídas em situações naturais, ainda existe uma grande necessidade de pesquisa investigativa nesse tema. Testes experimentais devem ainda ser feitos com barras corroídas naturalmente, sendo possível assim comparar tais resultados com aqueles obtidos com barras corroídas de maneira não natural, melhorando assim a aplicabilidade dos resultados.

François e Maso (1988) estudaram a influência dos efeitos causados por carregamentos mecânicos na carbonatação e penetração de cloretos em estruturas de concreto armado. Os corpos de prova consistiram em vigas de concreto armado com três metros de comprimento que foram mantidas em um estado de carregamento mecânico e em um ambiente agressivo. Os resultados mostraram que o dano na interface pasta/grão em zonas de tração leva a um aumento na penetração íons agressivos. Além disso, a carbonatação ou a penetração de cloretos depende da evolução da microestrutura do concreto devido a flexão mecânica (estado de carregamento). A contaminação por íons agressivos é mais importante em zonas de tração que em outras zonas. O aumento da porosidade resulta da danificação da interface pasta/grão em zonas de tração devido ao carregamento mecânico.

Por um período de 5 anos, Liu e Weyers (1998) simularam em laboratório a corrosão em lajes de pontes de concreto armado utilizando um total de 44 corpos de prova. Os parâmetros monitorados incluíram a taxa de corrosão (por meio da técnica de polarização), a resistência ôhmica e a temperatura. Um conjunto de 7 taxas de corrosão foram estabelecidas por meio do traço utilizado aumentando-se a quantidade de cloreto de sódio incorporado à massa de concreto. Foi desenvolvido um modelo de regressão não linear que demonstra que a corrosão do aço no 
concreto em condições de exposição de serviço é uma função do conteúdo de cloretos no concreto, temperatura, resistência ôhmica e tempo de ativação da corrosão. Dentre as técnicas empregadas, os autores concluem que a técnica de polarização linear não protegida é a que melhor estima a taxa média de corrosão anual. Os autores concluem que a taxa de corrosão aumenta com um aumento da temperatura e com a quantidade de íons cloreto. Contudo, ela decresce com o aumento da resistência ôhmica. A taxa de corrosão decai rapidamente nos primeiros anos após o início da corrosão e tende a alcançar certo valor após aproximadamente um ano da presença de uma quantidade constante de cloretos.

Conforme já comentado anteriormente, testes de corrosão acelerada sofrem grandes críticas pelo fato de não simularem adequadamente um comportamento real de uma estrutura. Tendo isso em mente, Castel et al. $\left(2000^{a}\right)$ realizaram experimentos em vigas de concreto armado submetidas ao ataque de cloretos em ambiente controlado por treze anos. Foram ensaiadas quatro vigas no total. Duas vigas foram expostas a um ambiente salino controlado em laboratório com ciclos de spray de sal, molhagem e secagem. As duas vigas de referência (não corroídas) foram armazenadas no laboratório e submetidas a ciclos de molhagem nos primeiros 6 anos. As duas vigas de referência foram mantidas em um estado de carregamento de flexão em três pontos. A carga aplicada correspondeu a carga de serviço. O objetivo do trabalho foi investigar a fissuração do concreto e a redução da seção transversal do aço causados pela corrosão das armaduras. Os autores concluíram que as fissuras que surgiram na parte comprimida não tiveram influência significativa no comportamento global das vigas. Contudo, as fissuras que surgiram na parte tracionada das vigas modificaram significativamente o comportamento observado. A redução da rigidez a flexão e um comportamento assimétrico caracterizaram essa mudança. No estado limite de serviço tanto a redução da área de aço das armaduras tracionadas quanto a redução da aderência entre o aço e concreto se mostraram significativos na redução da rigidez flexional (em torno de 35\%). Já no estado limite último a redução da aderência entre aço e concreto não se mostrou relevante com relação a capacidade de suporte da viga. Além disso, houve uma redução de $70 \%$ na ductilidade de uma das vigas, o que pode ser atribuído a redução da ductilidade das armaduras tracionadas. Esse último resultado está de acordo com as pesquisas relacionadas a capacidade residual de barras de aço corroídas apresentadas por Almusallam (2001), Lee et al. (2002), Cairns et al. (2005), Du et al. (2005 e 2005 b), Apostolopoulos et al. (2006), Apostolopoulos e Papadopoulos (2007), Apostolopoulos e Papadakis (2008) e Apostolopoulos e Kappatos (2013).

Uma segunda parte desse trabalho é apresentada no mesmo ano pelos mesmos autores (CASTEL et al., 2000 b). Contudo, o objetivo desse trabalho foi investigar a resistência de 
aderência no comportamento mecânico de vigas de concreto armado corroídas. Na simulação experimental a redução da aderência entre aço e concreto foi feita removendo o concreto de cobrimento das armaduras tracionadas em comprimentos variáveis. Já a redução da seção transversal das armaduras devido a corrosão por pites foi feita criando-se entalhes locais. Foram usadas três vigas não corroídas de referência e uma viga corroída. Todas as vigas foram submetidas a uma taxa constante de carregamento até alcançarem a sua carga de serviço. Os resultados mostraram que uma redução da seção transversal de aço, localizada entre as fissuras de tração, não tem influência no comportamento global quando a aderência entre aço/concreto não é modificada. Os autores explicam que o comportamento global das vigas parece ser afetado fortemente quando ambos os fenômenos estão acoplados por causa do crescimento local na tensão do aço devido à redução de sua seção transversal e na contribuição do concreto à tração.

A partir de uma análise experimental, Vidal et al. (2004) apresentam uma equação na qual é possível calcular a perda da área de aço necessária para ocasionar a abertura de fissuras, em função do diâmetro inicial da armadura e do cobrimento. Os resultados obtidos foram baseados em ensaios realizados em vigas corroídas naturalmente por períodos de 14 e 17 anos. As vigas foram corroídas em uma câmara no laboratório com ciclos de molhagem, secagem e exposição a cloretos por meio de borrifadores. Foram estudadas duas vigas apenas, uma com cobrimento de $4 \mathrm{~cm}$, dimensionada segundo o estado último de serviço e inserida em ambiente agressivo e outra com cobrimento de $1 \mathrm{~cm}$, dimensionada segundo o estado limite último e inserida em ambiente não agressivo. Os autores concluem que a iniciação da fissuração depende da razão cobrimento/diâmetro da barra e do diâmetro da barra em si. Com relação a propagação da fissuração, a razão cobrimento/diâmetro da barra e o diâmetro da barra em si não parecem ter efeito na evolução da largura da fissura. Já a redução da seção transversal de aço aparece como o principal parâmetro influenciador nessa fase. Vale destacar que, no cálculo da perda da área de aço que ocasiona o início da abertura de fissuras, não são consideradas as propriedades do concreto, o que torna o modelo limitado. Outra crítica relaciona-se ao fato de que somente duas vigas foram ensaiadas, sendo uma amostragem muito pequena. Nesse aspecto, os autores justificam que foram usados diversos diâmetros de armaduras e espessuras de cobrimento. Além disso, argumentam que a corrosão por pites ocorreu em trechos de no máximo $0,5 \mathrm{~mm}$ de extensão e que assim cada trecho da viga poderia ser considerado uma amostra individual. Contudo, os autores não consideraram que fissuras surgindo em localizações diferentes ao longo do comprimento longitudinal das barras podem interferir na evolução umas das outras.

Vidal et al. (2007) apresentam um outro trabalho onde vigas de concreto armado foram armazenadas em um ambiente com cloretos por 17 anos e ao mesmo tempo submetidas a um 
carregamento de serviço. Durante o período de propagação, apesar das condições ambientais bastante controladas do laboratório, a distribuição da corrosão e sua evolução ao longo de todas as barras de aço se apresentou bastante distinta e heterogênea. Essa observação diz respeito a localização, a intensidade e a taxa de corrosão das áreas corroídas em uma mesma barra e também entre duas barras diferentes. Isto destaca a dificuldade de modelar a evolução da corrosão com o tempo, considerando os numerosos parâmetros envolvidos como as condições ambientais (umidade, temperatura, condição de exposição, etc.), características do concreto (físicas, químicas, mecânicas, etc.) e a condição de interface aço/concreto. O desempenho estrutural sob cargas de serviço é afetado pela corrosão das armaduras tracionadas e não significativamente pela fissuração do concreto devido a corrosão das barras localizadas na zona de compressão. A redução da rigidez resulta de dois fatores acoplados: a redução da seção transversal do aço e a perda da aderência aço/concreto devido a corrosão do aço em zonas localizadas entre fissuras de flexão ao longo da viga. Essas últimas observações estão de acordo com o trabalho apresentado por Castel et al. $\left(2000^{\mathrm{a}}\right.$ e $\left.2000^{\mathrm{b}}\right)$.

Al-Harthy et al. (2011) apresentam os resultados de testes de corrosão acelerada conduzidos na Universidade de Newcastle (Austrália) e propõem um modelo para a análise do período de iniciação e de propagação da corrosão em lajes de concreto armado. No estudo os pesquisadores variaram as condições de confinamento das barras, a resistência do concreto, o cobrimento e o diâmetro das barras. Os comprimentos das fissuras, dependentes do tempo, foram medidos para diferentes lajes de concreto para altas taxas de corrosão. Foi verificado que as previsões para o tempo de início da fissuração são altamente dispersas (dentre nove modelos testados) e podem diferir em até duas ordens de magnitude. Os autores concluíram também que o tempo de iniciação e propagação da fissuração aumentam com um aumento do cobrimento e decrescem com um aumento do diâmetro das barras e com a resistência a compressão do concreto. A taxa de propagação de fissuração observada foi de 10 a 50\% maior para armaduras com confinamento reduzido, como nas bordas de lajes ou nas quinas de um pilar.

Um trabalho experimental com resultados bastante interessantes, especialmente no que diz respeito a duração do ensaio, é apresentado por Dang e François (2013). Os autores investigaram o desempenho de vigas de concreto armado corroídas por 27 anos em câmaras contendo cloretos em laboratório. O desempenho mecânico foi reduzido em termos da carga última e da ductilidade. Os resultados experimentais revelam um maior modo de falha frágil das vigas de concreto armado corroídas em comparação com o modo de falha dúctil de uma viga de controle com a mesma idade em ensaios de flexão. Isto está ligado à mudança das propriedades mecânicas das barras de aço corroídas em comparação com as barras não corroídas. Além disso a 
distribuição da corrosão ao longo do perímetro das seções transversais e ao longo do comprimento das barras se mostrou bastante heterogênea, mesmo para condições estritamente idênticas de exposição aos cloretos. Os autores atribuem a redução do momento de escoamento e do momento último da viga de concreto armado apenas à redução da seção transversal da barra de aço no local da falha. Contudo, outros fatores também contribuem para a redução da resistência da viga como a redução da tensão de escoamento das barras de aço e a alteração do mecanismo de transferência de tensões entre o concreto e as armaduras. A respeito deste último fator vale destacar que a corrosão em níveis avançados acaba por eliminar as nervuras das barras de aço, consumindo o metal presente nas reações químicas governantes do processo. Esse último resultado corrobora com àqueles obtidos por Du et al. $\left(2005^{\mathrm{a}}\right.$ e $\left.2005^{\mathrm{b}}\right)$.

Outro trabalho experimental com vigas de concreto corroídas é apresentado por Yu et al. (2015). Foi realizado um estudo da iniciação e propagação da corrosão em vigas de concreto armado pré fissuradas submetidas a carregamentos mecânicos durante a exposição a ambientes com cloretos. Foram comparados resultados experimentais obtidos de vigas de concreto armado de dois conjuntos de idade: com 4 anos e 29 anos. As únicas diferenças entre os dois conjuntos de vigas foram a direção da moldagem em relação as armaduras de tração e as condições de exposição na câmara de névoa salgada. Os resultados experimentais mostram que, após a rápida iniciação da corrosão na ponta da fissura, o processo corrosivo praticamente foi interrompido e o tempo decorrido antes da retomada da corrosão dependeu das condições de exposição e da espessura de cobrimento. Além disso, a qualidade da interface aço/concreto desempenha um papel significativo com relação ao dano induzido por cargas e/ou dano induzido pela moldagem. Como resultado, apesar do mesmo concreto de cobrimento, barras que não são afetadas por dano induzido por cargas ou moldagem permanecem em um estado passivo, enquanto barras afetadas por dano de moldagem (efeito da barra de topo) e/ou dano induzido por cargas (barras tracionadas) estão em um estado ativo. Os resultados mostram que uma interface aço/concreto sã permite as barras agirem como cátodos, enquanto que defeitos na interface aço/concreto promovem um comportamento anódico. Uma limitação do estudo diz respeito a quantidade de traços considerados, no caso, somente um. Uma maior qualidade no concreto poderia limitar o efeito de danificações causadas pela moldagem dos elementos.

\subsubsection{Estudos utilizando o método dos elementos de contorno}

Métodos numéricos são ferramentas para resolver problemas matemáticos que são formulados de maneira que sua solução envolva somente operações aritméticas. O desenvolvimento e a popularidade dos métodos numéricos cresceram com o surgimento de 
ferramentas que agilizassem a grande quantidade de cálculos necessários, como os computadores, especialmente nos anos 60. Exemplos de aplicação dos métodos numéricos incluem a solução de equações diferenciais, métodos matriciais para solução de sistema de equações, integração numérica via métodos de aproximação ou estatísticos, solução de equações diferencias parciais, métodos matriciais para a solução de problemas de autovalor e autovetor, entre outros.

Num contexto de engenharia, atualmente pode-se dividir os métodos numéricos em dois grandes grupos: métodos de domínio e métodos de contorno. Como fica evidente no próprio nome do grupo, nos métodos de domínio as aproximações são feitas no domínio do problema. Dentro deste grupo pode-se citar o método dos elementos finitos (MEF) e o método das diferenças finitas (MDF). Já no segundo grupo as aproximações são feitas no contorno do problema com as condições de contorno sendo obedecidas no domínio. Nesse grupo destaca-se o método dos elementos de contorno (MEC), utilizado no presente trabalho.

Dentre as principais vantagens do MEC destaca-se a redução em uma dimensão na discretização do problema. Essa redução conduz a menores sistemas de equações e consequentemente a um menor tempo de processamento computacional. Esse efeito é mais evidenciado quando o domínio do problema, ou parte dele, é ilimitado. No MEC é possível modelar o comportamento no infinito sem a necessidade de utilizar uma malha para essa aproximação, como no caso dos métodos de domínio. A redução em uma dimensão na discretização do problema se traduz também em uma diminuição no tempo de preparação da malha, que é uma tarefa bastante dispendiosa no procedimento numérico. A conformação às fronteiras do domínio também merece destaque nesse método. Em problemas envolvendo mudanças de contorno, o remalhamento é mais facilmente realizado dentro do MEC do que em métodos de domínio.

Contudo, o MEC apresenta algumas desvantagens se comparado com os métodos de domínio. A matriz que define o sistema final de equações normalmente é cheia e não simétrica, o que dificulta a sua solução computacional. A construção das matrizes contendo os núcleos integrais pode ser computacionalmente onerosa. Além disso, o MEC requer a existência de soluções fundamentais que não são sempre fáceis de serem obtidas. Por fim, o MEC envolve uma abordagem matemática mais refinada e que muitas vezes num contexto de engenharia, não é muito atrativa.

O MEC fundamenta-se basicamente na conversão da equação diferencial que rege um determinado problema em uma equação integral. Para essa conversão normalmente utilizam-se as soluções fundamentais e manipulações algébricas empregando por exemplo a técnica de integração por partes, o teorema da divergência de Gauss, o teorema de Green, entre outros. 
Ao que se sabe, foi no continente europeu onde primeiramente utilizaram-se das equações integrais para resolver problemas práticos. Com apenas 21 anos de idade, um matemático norueguês chamado Niels Henrik Abel (1802-1829) foi um dos pioneiros na utilização de equações integrais para resolver problemas. Em 1823 ele apresentou a solução para o problema do pêndulo isócrono utilizando tal abordagem. Contudo, a fundamentação matemática por detrás da solução de Abel (1823) deve-se em grande parte a importantes cientistas como Euler (1707-1783), Lagrange (1736-1813), Laplace (1749-1827), Fourier (17681830) e Poisson (1781-1840). Ainda dentro do contexto da fundamentação matemática que possibilitou o surgimento do MEC pode-se citar Gauss (1777-1855), Cauchy (1789-1857), Green (1793-1841), Ostrogradski (1801-1862), Dirichlet (1805-1859), Hamilton (1805-1865), Stokes (1819-1903), Helmholtz (1821-1894), Betti (1823-1892), Kelvin (1824-1907), Neumann (18321925), Rayleigh (1842-1919), Volterra (1860-1940), Somigliana (1860-1955), Hadamard (18651963), Fredholm (1866-1927), Kolosov (1867-1936), e Kellogg (1878-1932).

Soluções numéricas antes do advento dos computadores digitais já estavam sendo desenvolvidas, ainda que num estágio embrionário, por pesquisadores como Ritz (1878-1909), Kármán (1881-1963), Trefftz (1888-1937) e Muskhelishvili (1891-1976). Após o advento dos computadores digitais, metodologias e estudos importantes foram desenvolvidos por Kupradze (1903-1985), Jaswon (1922-2011), Rizzo (1938-), Cruse (1941-) e Brebbia (1948-2018).

A técnica dos resíduos ponderados aplicada a equações integrais foi apresentada por Brebbia $\left(1978^{2}\right)$. Tal equacionamento possui certa analogia com outros métodos numéricos como o MEF e o MDF, o que fez com que a combinação entre diferentes técnicas numéricas fosse facilitada. O acoplamento entre diferentes métodos numéricos é uma estratégia interessante para tratar de determinados problemas, uma vez que cada método possui determinadas vantagens que podem ser devidamente usufruídas. A nomenclatura "método dos elementos de contorno" surgiu a partir dos trabalhos de Brebbia $\left(1978^{a}, 1978^{b}\right)$ que, até então, possuía a denominação de "método das equações integrais".

Atualmente diversos trabalhos e pesquisas estão sendo desenvolvidos tendo por base o MEC. Esse método numérico é frequentemente utilizado em problemas da mecânica da fratura, mecânica dos fluídos, acústica e mecânica do contato. Contudo, a simulação de problemas de difusão em meios porosos, como o concreto, empregando esse método numérico não é muito usual, sendo o MEF mais comumente utilizado. Vale ressaltar que, no contexto do MEC, a difusão nada mais é do que um problema de potencial descrito por uma equação diferencial que satisfaz a equação de Laplace ou de Poisson. Outros problemas de potencial similares à difusão 
que podem ser citados são: escoamento de fluídos ideais, torção de barras e transferência de calor.

Um dos primeiros estudos relacionados a transformação da equação diferencial de potencial em uma equação integral de contorno foi feito por Rizzo e Shippy (1970). Os autores aplicaram a formulação direta do MEC em conjunto com a transformada de Laplace para resolver problemas de condução de calor transiente. Uma abordagem envolvendo transformações entre espaços permitiu remover temporariamente a dependência do tempo da equação, tornando a equação diferencial parcial parabólica original do problema em uma equação diferencial parcial elíptica.

Em contrapartida, a formulação indireta do MEC foi apresentada por Butterfield e Tomlin (1972) e Tomlin (1972). Os autores aplicaram a formulação no estudo de meios ortotrópicos, comuns na área de engenharia geotécnica. Soluções transientes foram geradas através da distribuição instantânea de fontes espalhadas pela região do problema no tempo zero para reproduzir as condições iniciais e fontes contínuas sobre a região de contorno e as interfaces, satisfazendo assim as condições prescritas de contorno e interface.

Além das formulações direta e indireta do MEC, anteriormente comentadas, uma formulação alternativa envolvendo soluções fundamentais dependentes do tempo é apresentada por Chang et al. (1973). O problema investigado envolvia a transferência de calor em meios isotrópicos e ortotrópicos. A discretização da equação integral de contorno foi feita utilizando valores constantes por partes no espaço e no tempo para as variáveis. Uma abordagem similar é apresentada por Shaw (1974) para a solução de problemas em três dimensões, com enfoque especial na parte analítica do método. Essa formulação foi posteriormente estendida por Wrobel e Brebbia (1979) a fim de permitir a utilização de funções de interpolação de alta ordem no espaço e no tempo. Wrobel e Brebbia (1981) apresentam também um procedimento numérico para resolver problemas transientes axissimétricos, onde a complexidade das soluções fundamentais requer a introdução de expansões em série para tornar possível a integração analítica no tempo da equação integral de contorno.

Uma formulação alternativa envolvendo o acoplamento entre elementos de contorno e o método das diferenças finitas tratando de problemas transientes é apresentada por Brebbia e Walker (1980). A derivada temporal é aproximada por diferenças finitas e um procedimento incremental é empregado para avançar com a solução no tempo.

$\mathrm{O}$ uso de soluções fundamentais independentes do tempo com um tratamento aproximado do termo de derivada temporal é explorado por diversos autores como Wrobel et al. (1986), Ingber e Mitra (1987), Taigbenu e Liggett (1986) e Loeffler e Mansur (1988). Por 
exemplo, Aral e Tang (1988) propõem uma metodologia para a integração numérica temporal por meio de uma solução via elementos de contorno para equações diferenciais parciais parabólicas. Um número selecionado de pontos interiores pode também ser incluído no processo de cálculo para aumentar a precisão. Os autores especificam que essa característica da técnica proposta pode se mostrar muito efetiva para problemas onde mudanças rápidas no valor da variável dependente são esperadas em certos pontos na solução de domínio, como problemas de convecção-difusão. Os autores comparam sua formulação àquela de Taigbenu e Liggett (1986), onde, para a mesma discretização adotada, resultados similares são obtidos, porém com uma redução de cinco vezes no tempo de processamento computacional. Contudo, Wrobel (1988) argumenta que formulações de elementos de contorno com reciprocidade dual são ainda mais eficientes que àquelas apresentadas por Aral e Tang (1988) pois não há necessidade de discretização e tampouco integração no domínio. A aplicação de tal técnica é mostrada no trabalho de Wrobel e Brebbia (1987).

Historicamente, problemas de potencial envolvendo meios heterogêneos usando o MEC usualmente emprega a técnica de sub-regiões, cuja eficácia foi estudada por autores como Gipson (1987), Azevedo e Wrobel (1988) e Bialecki e Khun (1993). Contudo, existem abordagens alternativas nesse contexto. Kassab e Divo (1996) apresentam uma abordagem utilizando soluções fundamentais generalizadas para problemas de condução estacionária de calor usando o MEC com uma variação espacial termal arbitrária. Essa técnica consiste em gerar a solução fundamental com o auxílio de uma função generalizadora imposta com propriedades especiais de amostragem.

Tratando de problemas de difusão-convecção em regime estacionário, Brebbia e Skerget (1984) apresentam uma formulação do MEC utilizando uma solução fundamental independente do tempo. Já no caso transiente, é utilizada uma solução fundamental dependente do tempo. Nesse mesmo contexto, outra solução é apresentada por DeSilva et al. (1998) empregando velocidades variáveis e células de domínio.

Singh e Tanaka (2000) apresentaram uma formulação do método dos elementos de contorno alternativa baseada na transformação exponencial variável para problemas de difusãoadvecção estáveis, convertendo a equação da difusão-advecção na equação de Helmholtz modificada. Nesse trabalho os autores discutem três transformações e diferenciam seu uso para problemas dominados pela difusão e advecção. Já Ochiai (2001) apresenta a análise de difusão do calor transiente bidimensional utilizando na formulação do MEC uma solução fundamental independente do tempo. Nesse trabalho o autor demonstra que é possível obter distribuições de temperatura satisfatórias com o uso de soluções fundamentais de baixa ordem. 
Sutradhar e Paulino (2004) apresentaram uma análise para a condução de calor transiente sem a discretização do domínio, transformando um problema não homogêneo em um problema de difusão homogênea a partir da transformada de Laplace e de aproximações de Galerkin. Problemas de transmissão dinâmica de calor foram estudados por autores como Young et al. (2004), Azis e Clements (2008) e Abreu (2013) adotando soluções fundamentais com dependência temporal.

Tanaka et al. (2008) apresentaram uma formulação do MEC com reciprocidade dual para problemas de condução bidimensional do calor transiente em meios anisotrópicos. Esse trabalho fez uso de uma solução fundamental independente do tempo para materiais isotrópicos e esquema de marcha no tempo baseado em diferenças finitas.

Belkhayat (2011) apresenta uma formulação do método dos elementos de contorno intervalado para problemas de difusão transiente usando uma abordagem de aritmética de intervalo direcionado. Nessa aritmética, um conjunto de intervalos próprios é estendido em intervalos impróprios e todas as operações e funções aritméticas são também estendidas. A principal vantagem da aritmética de intervalo direcionado em comparação com a usual aritmética de intervalo é que os intervalos de potencial (temperatura ou concentração) obtidos são muito mais estreitos e seus comprimentos não aumentam com o tempo. O método de eliminação de intervalo de Gauss com o procedimento de decomposição foi aplicado para resolver o sistema de equações de intervalo obtido. O trabalho apresenta certas limitações como a utilização apenas de elementos geometricamente lineares, além de exemplificar casos onde o domínio é regular.

Loeffler e Costalonga (2012) utilizaram a técnica da reciprocidade dual para resolver problemas difusivo-advectivos, variando a velocidade do escoamento e analisando a influência no transporte de energia diante da difusão térmica. Guo et al. (2013), apresentaram uma formulação para resolver problemas tridimensionais de condução e geração de calor transiente. Nesse trabalho, a dependência do tempo no problema foi removida temporariamente das equações pela transformada de Laplace, preservando as equações integrais de contorno, evitando-se a discretização do domínio.

Guo et al. (2012) propõem um método de elementos de contorno sem malha transiente para prever a difusão de cloretos no concreto com coeficiente não linear dependente do tempo. Por meio do acoplamento do método de integral radial e da função de aproximação radial, as integrais de domínio em equações de controle equivalente são transformadas em integrais de contorno. Seguindo o procedimento geral de malhamento em elementos de contorno e o tradicional método das diferenças finitas, um conjunto de equações algébricas não lineares é construído e é eventualmente resolvido com o método iterativo de Newton modificado. Os 
efeitos não lineares do processo de penetração dos cloretos, como a dependência da difusividade do concreto na tortuosidade, são considerados por meio de um coeficiente de difusão que engloba a concentração de cloretos.

Al-Jawary et al. (2012) apresentam uma nova formulação para a solução numérica de problemas de difusão bidimensionais com coeficientes variáveis. Os autores utilizam o método da integração radial da equação de contorno e o método da integração radial da equação de contorno integral-diferencial. Os métodos utilizam uma função especial (função de Levi) ou a solução fundamental padronizada para a equação de Laplace para reduzir o problema de valor de contorno em uma equação integral de contorno/domínio ou uma equação integral-diferencial de contorno/domínio. A formulação resultante conduz puramente a integrais de contorno e equações integro-diferenciais sem integrais de domínio. As formulações desenvolvidas são implementadas para a solução numérica de três possíveis casos: equações homogêneas, equações não homogêneas e equações com coeficiente de difusão variável. Os resultados apresentados estão de acordo com respostas analíticas disponíveis, porém o exemplo de aplicação reportado no trabalho é para um domínio regular (retângulo) apenas.

Uma interessante estratégia é apresentada por Yang et al. (2013) no que diz respeito a utilização do MEC para a análise numérica da difusão bidimensional de cloretos em concreto. Os autores propõem uma estratégia envolvendo um "comprimento de compensação" assim como um "coeficiente de compensação" em função do coeficiente de difusão e do tempo de análise. Esse "comprimento de compensação" e o "coeficiente de compensação" são calculados no início da análise e comparados com o comprimento real do elemento (lado). Se o comprimento de compensação for maior que o comprimento real então usa-se o comprimento de compensação, caso contrário usa-se o comprimento real do elemento. No modelo de elementos de contorno proposto com o comprimento de compensação, o intervalo de tempo (duração) é esparsamente discretizado em apenas alguns subdomínios, enquanto que o domínio espacial é discretizado ao longo do contorno do concreto de forma que um significante menor número de incógnitas é envolvido.

Yu et al. (2014) analisaram problemas de condução do calor transiente com o uso de integração radial na formulação do MEC. Em tal análise os autores resolveram o problema de condução para meios os quais apresentam condutividades térmicas variáveis.

Wang e Chen (2015) utilizam o método dos elementos de contorno rápido com multipólos baseados em uma formulação com reciprocidade dual. $\mathrm{Na}$ formulação de reciprocidade dual, integrais de domínio que surgem a partir da solução de problemas de valor de contorno dependentes do tempo são transformadas em integrais de contorno por meio da 
construção de soluções particulares. As derivadas no tempo nas equações diferenciais governantes são aproximadas com um esquema de marcha no tempo envolvendo diferenças finitas de primeira ordem. Os autores apresentam três exemplos: difusão em uma placa quadrada com condições de contorno de Dirichlet-Neumann, problema que possui solução analítica, difusão térmica em uma placa com vários furos e difusão de oxigênio em um tecido cardíaco.

Uma abordagem via MEC envolvendo tanto a difusão quanto o comportamento mecânico em estruturas de concreto a fim de modelar a fissuração devido a corrosão é apresentada por Cheng e Leung (2017). A distribuição espacial e temporal da profundidade de corrosão ao redor das seções transversais de aço durante o processo corrosivo é primeiramente calculado a partir de uma análise de difusão no módulo de corrosão. Baseado em dois métodos dos elementos de contorno indiretos, o método da tensão fictícia e o método da descontinuidade de deslocamentos, o problema mecânico do compósito concreto/ferrugem/aço sob expansão devido à ferrugem é formulado. Contudo, vale ressaltar que é muito difícil identificar a composição e a razão volumétrica dos produtos corrosivos sob diversas condições ambientais. Uma vez que um dos mais sensíveis parâmetros de entrada é esta razão volumétrica, conforme explicado pelos autores e, sendo a sua estimativa bastante incerta, a aplicabilidade real do modelo para a previsão da evolução da largura das fissuras fica bastante comprometida. Outra limitação do estudo refere-se à consideração do valor limite de cloretos como sendo constante e a taxa de corrosão ao longo do tempo também.

\subsubsection{Estudos envolvendo confiabilidade e otimização}

A aleatoriedade está presente e é inerente aos fenômenos estudados pela ciência. Abordagens determinísticas podem ser aprofundadas considerando-se a presença de incertezas e suas consequências nos fenômenos investigados. Especificamente na área de engenharia de estruturas, as incertezas envolvidas com a resistência dos materiais e com as ações atuantes necessitam ser adequadamente quantificadas e endereçadas para que um dado nível de segurança estrutural possa ser atribuído. Não é possível garantir plenamente que um sistema estrutural responderá sempre conforme previsto ou desejado. Assim, as incertezas presentes trazem como consequência uma possibilidade de que o sistema estrutural não responda conforme o esperado. Se essa possibilidade for quantificada em termos de probabilidades, busca-se então a assim chamada probabilidade de falha, que pode ser entendida como a probabilidade de que o sistema estrutural apresente um comportamento indesejado.

Os sistemas estruturais devem ser projetados, construídos e eventualmente submetidos à manutenção a fim de que cumpram um conjunto de requisitos com um nível aceitável de 
segurança. Esses requisitos estão ligados a função a qual a estrutura foi concebida durante toda a sua vida útil, a resistência a carregamentos cíclicos ou esporádicos, a proporcionalidade entre a intensidade da ação e o nível de dano gerado, entre outros. Esses requisitos podem ser equacionados na forma de estados limites. Os estados limites são originados a partir de configurações indesejadas para as estruturas, também chamados genericamente de modos de falha. Os dois grupos de estados limites principais são: estados limites últimos e estados limites de serviço. Alguns exemplos de estados limites últimos são: perda de equilíbrio estrutural, ruptura ou deformação excessiva do material, instabilidade, mudança súbita de configuração, plastificação e danificação. Alguns exemplos de estados limites de serviço são: fissuração, fadiga, corrosão (até certo nível) e vibração excessiva.

O desenvolvimento de pesquisas envolvendo a consideração de incertezas na engenharia de estruturas ocorreu a partir da segunda década do século XX. As primeiras formulações matemáticas a respeito de segurança estrutural podem ser atribuídas a Mayer (1926), Wierzbicki (1936) e Streletzkii (1947). Eles identificaram que as cargas e os parâmetros de resistência são variáveis aleatórias e, portanto, para cada estrutura, existe uma probabilidade de falha finita (NOWAK e COLLINS, 2000). Freudenthal (1947) aparece como o pioneiro a discutir o uso das teorias estatísticas para a avaliação da segurança estrutural. $\mathrm{O}$ autor propõe que a probabilidade de falha seja calculada pela integração de uma região caracterizada pelas distribuições de probabilidade das variáveis, chamada de domínio de falha. Cornell (1969) propôs o índice de confiabilidade de segundo momento, definido como a razão entre a média e o desvio padrão da equação de estado limite. $O$ índice de confiabilidade pode ser calculado desta forma para equações de estado limite lineares e com variáveis aleatórias descritas por distribuições normais. Hasofer e Lind (1974) formularam uma forma invariante de índice de confiabilidade. O índice de confiabilidade é descrito pelos autores como sendo a menor distância entre a origem do sistema de coordenadas até o ponto sobre a superfície de falha da estrutura que possui maior probabilidade de ocorrência, no espaço normal padrão multivariado e não correlacionado. Rackwitz e Fiessler (1978) apresentam um procedimento numérico iterativo para o cálculo do índice de confiabilidade. As funções de probabilidade das variáveis podem não seguir somente a distribuição normal, sendo necessárias neste caso transformações que permitam considerar tais variáveis como normais equivalentes. Fiessler et al. (1979) fizeram uma revisão sobre métodos aproximados de confiabilidade, dando atenção especial aos métodos FORM (First Order Reliability Method) e SORM (Second Order Reliability Method). Os autores indicam que a probabilidade de falha depende da curvatura da equação de estado limite no ponto de projeto, do tamanho do vetor de variáveis aleatórias e do tipo de distribuição dessas variáveis. Caso as variáveis aleatórias 
apresentem distribuição estatística bem distante da distribuição normal ou caso o vetor de variáveis aleatórias seja grande, a equação de estado limite possui grande possibilidade de apresentar elevada não linearidade.

As pesquisas em confiabilidade aplicadas a engenharia de estruturas desenvolvidas até então serviram como base para amplas mudanças nas normas de projeto. Até por volta do início dos anos 90, o conceito de tensões admissíveis norteou as normas. Um fator de segurança central, bastante simplificado, era utilizado para criar uma margem de segurança para a estrutura. Contudo, o tamanho de tal margem de segurança, assim como o valor da probabilidade de falha estrutural, não eram explicitados no projeto.

Ao longo dos anos 70 e 80, diversos pesquisadores se esforçaram a fim de que os conceitos de probabilidade de falha e estados limites fossem incorporados as normas de projeto. Como resultado, normas com conceitos semiprobabilísticos foram criadas e consolidadas ao longo dos anos seguintes. O nível de segurança estrutural é determinado em função de um conjunto de coeficientes parciais de segurança. Tais coeficientes de segurança são determinados a partir de ferramentas da teoria de confiabilidade que resultem em níveis de segurança aceitáveis para cada estado limite considerado.

A partir dos anos 90, uma quantidade expressiva de estudos envolvendo conceitos de confiabilidade e otimização começaram a ser realizados na área de engenharia de estruturas. A seguir apresentam-se alguns desses trabalhos, especificamente na área de difusão de cloretos e corrosão de armaduras em estruturas de concreto armado, que é o assunto abordado na presente tese.

Mori e Ellingwood (1994 e 1994 $)$ publicaram dois artigos que descrevem o papel da inspeção e reparação na manutenção da confiabilidade de estruturas de concreto para uma dada vida de serviço projetada, levando em consideração a aleatoriedade existente na danificação da estrutura e em sua detecção. Uma análise Bayesiana é utilizada para atualizar a função de distribuição de intensidade de dano após uma inspeção e reparação. A qualidade das inspeções é descrita por uma função de detectabilidade de danos. Uma vez que a inspeção e manutenção são custosas, existem relações de perde-e-ganha entre a extensão e precisão da inspeção e entre o nível requerido de confiabilidade e o custo. Por meio da metodologia apresentada, é possível traçar estratégias de inspeção e reparação necessárias para manter a probabilidade de falha da estrutura de concreto abaixo de um valor alvo. Estratégias ótimas de inspeção/reparo são sensíveis aos seus relativos custos de inspeção, reparação e falha, assim como ao valor limite de detecção de dano. Inspeções em intervalos aproximadamente uniformes conduziram a custos quase mínimos para uma variedade de casos estudados no trabalho. Contudo, vale destacar que 
os modelos de corrosão adotados no trabalho são simples e o dano cresce linearmente nos casos analisados no trabalho, o que nem sempre é verificado em casos práticos. A metodologia apresentada é aplicável apenas a equações analíticas bastante simples. A metodologia de otimização empregada utiliza uma técnica baseada em gradientes não lineares, conforme o trabalho de Murtagh e Saunder (1987). A resposta do problema de otimização depende fortemente do ponto inicial, o que conduz a uma solução ótima local.

Um dos primeiros estudos de confiabilidade de tabuleiros de pontes de concreto armado deterioradas foi feito por Val e Melchers (1997). O mecanismo de deterioração considerado foi a corrosão das armaduras. O método apresentado pelos autores inclui um modelo de carga de tráfego, um modelo de redução da área de aço baseado nas leis de Faraday e um modelo de análise estrutural não linear em elementos finitos. São consideradas dois tipos de corrosão: generalizada e localizada. Os autores consideram que todas as barras de aço da estrutura começam a ser corroídas ao mesmo tempo, o que é um cenário bastante pessimista. Em estruturas de concreto armado, normalmente tem-se corrosão acentuada em determinados pontos ao longo das armaduras. É utilizado o FORM para a análise de confiabilidade com uma busca direcional pelo ponto de projeto em coordenadas polares. A deterioração da estrutura analisada não teve um efeito notável na redução do índice de confiabilidade por um longo período após a iniciação da corrosão (em termos de estado limite ao momento fletor). Contudo, após esse período inicial, a confiabilidade estrutural reduziu-se rapidamente, especialmente no caso da corrosão localizada. Claramente tal observação é influenciada pelos parâmetros adotados nas análises, especialmente no valor assumido para a taxa de corrosão. Entretanto, a rápida tendência de redução da confiabilidade estrutural é uma forte justificativa para buscar prever e detectar a iniciação da corrosão.

Uma análise de confiabilidade um pouco mais detalhada da corrosão de pontes de concreto armado foi realizada por Stewart e Rosowsky (1998). Na pesquisa, os íons cloreto foram considerados como provenientes de sais de degelo. As probabilidades de falha foram avaliadas para estados limites a flexão e ao lascamento (spalling) do concreto. A lei de Fick unidimensional foi utilizada para calcular o tempo de início da corrosão e a simulação de Monte Carlo para calcular as probabilidades de falha acumuladas ao longo do tempo. A influência do cobrimento e da resistência específica a compressão do concreto se mostraram particularmente significantes na probabilidade de lascamento.

Um estudo de uma ponte de concreto armado existente no Reino Unido, submetida a três cenários de agressividade ambiental (baixa, média e alta) é apresentado por Thoft-Christensen (1998). No estudo o autor utiliza normas de carregamento europeias da época e considera dois 
estados limites últimos (escoamento das armaduras e falha por cisalhamento) e dois estados limites de serviço (abertura máxima de fissuras e flecha máxima). As equações que definem os estados limites são definidas todas de forma analítica. A quantidade de amostras utilizadas nas simulações de Monte Carlo é pequena para as probabilidades de falha calculadas. Além disso, o autor atribui distribuições do tipo normal para variáveis aleatórias como o coeficiente de difusão, concentração crítica de cloretos e concentração superficial de cloretos que usualmente são adotadas com outras distribuições. Além disso, o modelo difusivo utilizado envolve a lei de Fick unidimensional.

Ainda estudando pontes de concreto armado deterioradas pela corrosão com o avanço do tempo, Enright e Frangopol $\left(1998^{\mathrm{a}}, 1998^{\mathrm{b}}, 1999^{\mathrm{a}}\right.$ e $\left.1999^{\mathrm{b}}\right)$ apresentam uma série de trabalhos envolvendo uma análise probabilística da degradação da resistência, previsão da vida útil e estratégias de manutenção. O método de simulação de Monte Carlo com amostragem por importância é utilizado para encontrar a probabilidade de falha acumulada no tempo do sistema. Discussões são feitas a respeito da sensibilidade dos parâmetros de entrada na evolução da probabilidade de falha. Técnicas Bayesianas são empregadas, combinando assim informações de inspeção estrutural e julgamentos de engenharia para prever as condições de operação de pontes. Os autores utilizam equações analíticas simples para considerar a redução da área de aço. Em algumas análises apresentadas não há um modelo ou mesmo equação para o cálculo do tempo de iniciação da corrosão. Apenas considera-se o tempo de iniciação como sendo uma variável determinística com valores obtidos a partir de estudos paramétricos em vigas de concreto armado feito pelos autores. Em outras análises, utiliza-se a lei de Fick unidimensional. Contudo, nos trabalhos apresentados pelos autores não são consideradas as incertezas na fase de iniciação da corrosão das armaduras, ou seja, durante o processo difusivo. Os parâmetros utilizados na função de degradação de resistência são baseados em estudos em pontes de concreto sob corrosão conduzidos por Clear (1992) e por Whiting et al. (1993). Contudo, a representatividade da degradação estrutural das pontes reportadas pode ficar comprometida, uma vez que os históricos de degradação estrutural em pontes, até mesmo similares, podem ser completamente distintos.

Um estudo envolvendo dados reais de uma ponte sofrendo efeitos corrosivos foi apresentado por $\mathrm{Vu}$ e Stewart (2000). Três especificações de projeto de durabilidade e incrementos de carga variáveis com o tempo foram consideradas. O coeficiente de difusão é calculado por meio da equação dada por Papadakis et al. (1996) que leva em conta parâmetros como relação água/cimento, densidade dos agregados e do cimento. No trabalho é apresentada também uma equação derivada de um ajuste de dados experimentais apresentados por Liu e Weyers (1998) para o cálculo da taxa de corrosão dependente do tempo. Além disso, os autores 
utilizam dados reais de medidas em campo para adotar um valor médio e um coeficiente de variação para a concentração superficial de cloretos. A lei de Fick unidimensional é utilizada para simular o ingresso de cloretos. Os autores concluem que o cobrimento do concreto e a relação água cimento tem uma enorme influência nas probabilidades de colapso. Quando comparada ao caso "sem deterioração", foi observado que a probabilidade de falha apenas aumenta ligeiramente para boas especificações de projeto de durabilidade.

Um importante trabalho a respeito do custo do ciclo de vida de estruturas de concreto armado em ambientes marinhos sob diferentes condições de exposição foi apresentado por Val e Stewart (2003). São adotadas duas estratégias de reparação estrutural após ocorrer o lascamento do elemento estrutural. Na primeira o lascamento pode ocorrer uma ou mais vezes enquanto que na segunda a ocorrência do fenômeno não é considerada possível. Os autores analisam as influências das especificações de durabilidade de projeto e operações de manutenção na confiabilidade estrutural para estados limites de serviço. Em conjunto com uma análise probabilística do custo do ciclo de vida, os autores propõem um critério baseado em risco para a otimização de estratégias de reparação. Recomendações são feitas a respeito da resistência característica a compressão do concreto, o valor da espessura de cobrimento e a viabilidade de substituição das barras de aço convencionais por barras de aço inoxidável. Contudo, no estudo, a lei de Fick unidimensional é utilizada como modelo de previsão da iniciação da corrosão, sendo uma das simplificações do trabalho.

Buscando realizar uma análise considerando a variabilidade espacial da ação da corrosão ao longo das barras de aço, Stewart (2004) apresenta um estudo da influência da corrosão uniforme e por pites no comportamento de vigas de concreto armado simplesmente apoiadas. É um dos pouquíssimos estudos onde foi considerada essa variabilidade espacial explicitamente. $\mathrm{Na}$ metodologia apresentada, a viga é discretizada em uma série de elementos considerando-se profundidades aleatórias de pite para cada elemento e é utilizada a simulação de Monte Carlo para o cálculo das probabilidades de falha. A equação de estado limite é definida em termos da capacidade última à flexão da viga. Assume-se uma relação linear entre o momento resistente e a área de aço existente. Comparada com a corrosão uniforme, a corrosão por pites é mais crítica para pequenos diâmetros de armaduras. A probabilidade de falha calculada para casos em que a variabilidade espacial da corrosão por pites foi incluída na análise resultou até três vezes maior do que aquela desconsiderando-se tal variabilidade. É importante destacar que para estágios avançados de corrosão, o comportamento da viga pode mudar de dúctil para frágil (ALMUSALLAM, 2001; DARMAWAN e STEWART, 2003). Além disso, estados limites ao cisalhamento podem ser predominantes em determinados instantes da vida útil da estrutura 
(ENRIGHT e FRANGOPOL, 1999 ${ }^{\mathrm{b}}$ ). Logo, a análise apresentada no trabalho pode resultar em uma subestimativa da probabilidade de falha da viga. Além disso, o tempo para início da corrosão é assumido como sendo determinístico e igual para todos os pontos das armaduras de aço da viga de concreto. Contudo, para os casos mais comuns, estudos experimentais demonstram que a corrosão se inicia em tempos distintos ao longo de uma mesma viga de concreto.

Uma metodologia alternativa para a previsão probabilística da vida de serviço e planejamento de manutenção de estruturas de concreto submetidos a difusão de agentes agressivos é apresentada no trabalho de Biondini et al. (2006). O modelo de difusão utilizado no trabalho é baseado em um algoritmo evolucionário utilizando células autômatas, consistindo em um grid de espaços ou células com uma variável discreta em cada célula que pode assumir um número finito de estados. Detalhes desse tipo de simulação podem ser vistos em Wolfram (1994) e em Biondini et al. (2004). Um modelo simplificado para a evolução do dano tanto no aço quanto no concreto é também adotado, considerando-se uma relação linear entre a taxa de dano e a concentração do agente agressivo. Dois exemplos de aplicação são apresentados em pontes com seção transversal do tipo caixão. São traçados perfis de probabilidade de falha da estrutura versus momentos fletores de fissuração, de escoamento e últimos, para tempos de exposição a agentes agressivos variando de 0 a 50 anos. As probabilidades de falha são determinadas via simulações de Monte Carlo. Três estratégias de manutenção estruturais, incluindo intervenções essenciais e preventivas, são analisadas a fim de determinar qual delas resulta em um menor custo total de vida útil estrutural. Contudo, nas análises feitas a carga aplicada à estrutura é considerada invariável com o tempo e a aleatoriedade na concentração crítica de cloretos é determinística.

Duprat (2007) apresenta um estudo da confiabilidade de vigas de concreto armado simplesmente apoiadas submetidas à corrosão por meio de sais de degelo e brisa marinha. Foram considerados vários graus de agressividade ambiental, qualidade de concreto e opções de projeto nas análises, além de duas equações de estado limite analíticas: uma para momento fletor e outra para esforço cortante. As probabilidades de falha são calculadas por meio do FORM. O autor utiliza a lei de Fick unidimensional para calcular a concentração de cloretos ao longo do tempo em vigas, que é um elemento bidimensional. Isso é uma grave inconsistência que não é exclusiva deste trabalho.

Incorporando em seu modelo efeitos de danificação no concreto, Xiang e Zhao (2007) realizaram um estudo de confiabilidade dependente do tempo em estruturas de concreto submetidas a difusão de cloretos e com danos por fadiga envolvendo mecânica do dano, análise não linear e simulação numérica do processo de difusão. É apresentado um modelo de dano por fadiga no concreto. O processo de difusão de cloretos é analisado pelo método das diferenças 
finitas considerando-se a lei de Fick unidimensional e o coeficiente de difusão do concreto variando com o tempo e com o nível de dano. A análise de confiabilidade utiliza simulação de Monte Carlo com amostragem por importância. Análises numéricas feitas em uma viga de concreto protendido indicam que o acúmulo de dano por fadiga pode ter influência significativa na confiabilidade relacionada a concentração de cloretos, o que afeta diretamente a durabilidade da estrutura de concreto. Contudo, no trabalho consideram-se somente as incertezas relacionadas ao processo de difusão. O carregamento e o processo de fadiga são considerados como sendo determinísticos.

Em uma extensão de sua pesquisa, Biondini et al. (2008) aplicam a sua metodologia em seções transversais de pontes estaiadas submetidas a difusão de agentes agressivos externos. Enfoque é dado na análise do desempenho estrutural frente a incertezas. As estruturas são analisadas antes e após determinadas intervenções que aumentam sua vida útil. É utilizado o mesmo modelo de difusão utilizado em trabalhos passados dos autores, ou seja, um algoritmo evolucionário utilizando células autômatas. Uma análise de sensibilidade das variáveis aleatórias é realizada por meio de uma regressão utilizando mínimos quadrados. A sensibilidade das variáveis aleatórias se revelou consideravelmente variável com o tempo, o que significa que a importância relativa de certas variáveis aleatórias muda com o passar o tempo. Com a realização das intervenções estruturais de manutenção, essa variação é reduzida. Contudo, novamente, nas análises feitas a carga aplicada a estrutura é considerada invariável com o tempo e a aleatoriedade na concentração crítica de cloretos é determinística.

O estudo de Val e Trapper (2008) apresenta uma avaliação probabilística específica do tempo de iniciação da corrosão por cloretos. É apresentado um modelo para a modelagem bidimensional do transporte de íons cloreto no concreto considerando os mecanismos de difusão e de convecção. As equações diferenciais que descrevem a difusão e a convecção são resolvidas por meio do método das diferenças finitas. A capacidade de ligação de cloretos é incluída da análise por meio das clássicas isotermas de Freundlich e Langmuir. As probabilidades de despassivação de uma parede (1D) e de uma seção de uma coluna (2D) são calculadas por meio do método de simulação de Monte Carlo. Os resultados da análise mostram uma grande diferença entre a modelagem do fenômeno em uma e duas dimensões. Quando o transporte de íons ocorre em duas dimensões, a concentração de cloretos aumenta mais rapidamente no domínio, o que resulta em um aumento nas probabilidades de despassivação. Esse resultado está de acordo com um outro estudo realizado em estruturas a beira mar conduzido por Frier e Sørensen (2005). Uma problemática que se apresenta nesse estudo é que os parâmetros envolvidos para o cálculo do coeficiente de difusão de umidade, como a energia de ativação do 
processo de difusão de umidade e o fator de decaimento da difusão devido a redução da umidade, não possuem valores ou faixas de valores bem definidas. Além disso, em geral, tais parâmetros são obtidos a partir de estudos experimentais, realizados sob determinadas condições e hipóteses. Diante disso, o modelo apresentado se torna bastante restritivo quanto a sua aplicação.

Suo e Stewart (2009) apresentam uma análise de confiabilidade dependente do espaço e do tempo combinada com informações visuais de inspeção para prever a probabilidade e a extensão de fissuras em estruturas de concreto armado afetadas pela corrosão. O método de simulação de Monte Carlo é utilizado para calcular as porções atualizadas fissuradas das estruturas. Nas análises consideram-se vários cenários de inspeção que incluem diferentes intervalos de inspeção, número de inspeções, proporção de fissuras e largura de fissuras. Os autores concluem que a ocorrência ou observação de fissuração altera significativamente a previsão de fissuração futura. A utilização de informações visuais da estrutura para a atualização do modelo numérico e consequentemente da resposta em termos probabilísticos é uma das grandes vantagens da metodologia apresentada. Contudo, não são consideradas nas análises a interferência da fissuração nos estados limites envolvendo o colapso estrutural e nem mesmo em estados limites de serviço envolvendo deformações ou deslocamentos excessivos. O modelo para prever o tempo necessário para a ocorrência de uma fissura com largura crítica é baseado em ensaios experimentais e depende de uma série de parâmetros que são apresentados no trabalho apenas para casos específicos, reduzindo a aplicabilidade geral do modelo. Outra limitação do modelo é que o mesmo considera que as inspeções visuais realizadas são 100\% precisas, o que é uma idealização contra a segurança se aplicada a uma estrutura real, podendo resultar em uma subestimativa da previsão atualizada de danificação devido a corrosão.

Além dos fatores inerentes ao processo corrosivo, a influência e aleatoriedade das condições ambientais onde a estrutura está inserida podem ser decisivos na vida útil da mesma. Uma investigação da influência das condições climáticas na aceleração do processo de degradação estrutural é apresentado por El Hassan et al. (2010). O modelo proposto tem a vantagem de introduzir os efeitos da temperatura ambiente e da umidade relativa no processo de corrosão de elementos de concreto armado, especialmente o coeficiente de difusão e corrente de corrosão no aço. Um estudo paramétrico é primeiramente realizado para os parâmetros do modelo e depois para cada parâmetro climático separadamente (temperatura e umidade relativa). O efeito combinado dos dois parâmetros climáticos é considerado através de condições climáticas reais sob a mesma exposição a cloretos. Por essa razão, três cidades costeiras foram escolhidas para englobar diferentes condições climáticas. Os resultados mostraram que a probabilidade de falha 
devido a corrosão segue três diferentes estágios: um primeiro estágio de difusão dos cloretos, um segundo estágio de ativação da corrosão por pites com perdas significativas da integridade do elemento e um terceiro estágio de grande corrosão por pites com grandes aumentos da probabilidade de falha (i.e., grande perda de seção transversal de aço). A aplicação a dados climáticos reais indica que a umidade é mais importante no primeiro estágio da corrosão (i.e., durante a difusão de cloretos no concreto de cobrimento), enquanto que a temperatura é mais importante em acelerar a corrosão do aço, levando a falha. Finalmente, o efeito do diâmetro de barras de aço na corrosão foi investigado no caso de ambientes altamente agressivos. A escolha de um diâmetro apropriado para o aço, frequentemente considerado sem cuidado nos procedimentos de projeto dos elementos, pode significativamente afetar o tempo de vida de estruturas de concreto armado. Os autores utilizaram a simulação de Monte Carlo para calcular as probabilidades de falha e a lei de Fick para determinar a evolução da propagação de cloretos. As equações de Vu e Stewart (2000) são consideradas para o cálculo da redução da área de aço devido a corrosão por pites.

A combinação de efeitos causados por terremotos com o processo corrosivo é uma preocupação que engenheiros devem ter, especialmente em zonas a beira mar onde a atividade sísmica é intensa. O projeto, gerenciamento e previsão de comportamento de estruturas submetidas a sismos sob um ponto de vista probabilístico tem se desenvolvido bastante nos últimos anos. Uma das primeiras abordagens largamente utilizadas foi proposta por Cornell et al. (2002) e Yun et al. (2002) para estruturas de aço. Pouco tempo depois, Lupoi et al. (2003) aplicaram essa metodologia de análise para estruturas de concreto armado. Uma revisão de trabalhos anteriores relacionados ao desenvolvimento de ferramentas numéricas para a avaliação probabilística de estruturas solicitadas por sismos pode ser consultada em Pinto (2001).

Alguns trabalhos que procuraram avaliar a confiabilidade de estruturas submetidas contemporaneamente à exposição a cloretos e a cargas sísmicas são os de Choe et al. (2008), Kumar et al. (2009), Ghosh and Padgett (2010) e Simon et al. (2010). Tais trabalhos apresentam uma série de limitações tais como: modelos estruturais muito simplificados para avaliação da capacidade resistente e da carga atuante, e simplificações nos modelos de deterioração por corrosão. Neste contexto, Akiyama et al. (2011) apresentam um procedimento computacional para avaliar o risco associado a estruturas nesta situação. O exemplo apresentado trata-se de um píer de concreto armado, considerando-se a flambagem das barras longitudinais como o único estado limite da estrutura. Utiliza-se um método analítico para avaliar a relação entre a carga lateral atuante e o deslocamento até a ocorrência da flambagem. Utiliza-se a simulação de Monte Carlo para cálculo das probabilidades de falha. A análise foi feita considerando-se primeiramente 
somente a ação sísmica e em seguida a ação sísmica em conjunto com a penetração de cloretos. Conforme já esperado, a probabilidade de falha acumulada no tempo é significativamente afetada ao se considerar os efeitos corrosivos ocasionados pelos cloretos.

Um modelo englobando diversas variáveis como a capacidade de ligação de cloretos, a variação da temperatura, umidade e concentração superficial de cloretos, o efeito do envelhecimento do concreto e o fluxo de cloretos em ambientes não saturados é apresentado por Bastidas-Arteaga et al. (2011). O modelo de penetração bidimensional de cloretos é baseado em um acoplamento entre o método dos elementos finitos e o método das diferenças finitas. Um exemplo é apresentado comparando a resposta fornecida pelo modelo proposto com aquela fornecida pela lei de Fick, apontando as simplificações dessa lei e as vantagens de se utilizar um modelo numérico. O problema de confiabilidade é resolvido por meio de simulação de Monte Carlo com amostragem por hipercubo latino. As variáveis aleatórias de umidade e temperatura, consideradas como sendo variáveis ao longo do tempo, são modeladas por meio de um processo estocástico com base na expansão de Karhunen-Loève. A probabilidade de iniciação de corrosão resultou quase $30 \%$ maior quando a difusão foi modelada em duas dimensões em comparação com o caso unidimensional. O modelo inclui fatores como umidade e temperatura, sendo que acaba por ser dependente de diversos parâmetros para a determinação do coeficiente de difusão. Normalmente, tais parâmetros estão disponíveis somente para um pequeno número de tipos de cimento e localidades, havendo assim a necessidade de pesquisas complementares.

Um estudo para prever a violação de estados limites de serviço em estruturas de concreto armado no Japão foi realizado por Akiyama et al. (2012). O método proposto permite determinar a probabilidade de ocorrência da despassivação das armaduras e do início da fissuração devido a cloretos transportados pelo ar, independentemente da região, distância da costa e das propriedades do concreto controladas pela relação água/cimento. A partir de dados coletados em estações japonesas por 3 anos, os autores propõem uma equação para prever a quantidade de cloretos transportados pelo ar em função: da taxa de vento oceânico, da velocidade média do vento durante o período de observação e da distância da estrutura até a costa. A equação de estado limite de fissuração utilizada pelos autores é dada por Qi e Seki (2001), obtida a partir de um modelo em elementos finitos. A lei de Fick unidimensional é utilizada para modelar a difusão de cloretos no concreto. O método de simulação de Monte Carlo é utilizado para calcular as probabilidades de violação das equações de estado limite. Os autores propõem valores de índice de confiabilidade alvo e coeficientes de durabilidade para diversas localidades japonesas. Fatores como as formações geológicas ao redor da estrutura, precipitação e diferenças de topografia 
litorânea não são considerados na equação para prever a quantidade de cloretos transportados pelo ar.

Por meio de dois modelos probabilísticos semi-analíticos simplificados baseados nos métodos de confiabilidade de primeira e de segunda ordem (FORM/SORM), Saassouh e Lounis (2012) modelaram as incertezas dos parâmetros que regem a entrada de cloretos no concreto e o início da corrosão de armaduras de aço de estruturas de concreto armado submetidas a penetração de cloretos, a partir de sais de degelo. Os autores concluíram que a fim de alcançar uma baixa probabilidade de corrosão e um projeto durável, a espessura do cobrimento do concreto é o fator de maior influência e que é importante identificar a severidade do ambiente, tipo de concreto e o tipo de armadura para definir diferentes classes de projeto de durabilidade para estruturas de concreto construídas em ambientes com a presença de cloretos. A limitação do trabalho apresentado pelos autores está justamente no modelo difusivo utilizado, que consiste na lei de Fick unidimensional. Além disso, para validar sua análise, os autores usam como resposta de referência o resultado fornecido pelo método de simulação de Monte Carlo.

Um interessante trabalho a respeito da previsão dos impactos das futuras mudanças climáticas no comportamento de estruturas é apresentado por Stewart et al. (2012). Nesse trabalho os autores aplicam modelos desenvolvidos anteriormente para prever o aumento dos riscos de danificação devido a corrosão sob mudanças climáticas em termos de mudanças de probabilidade de iniciação da corrosão nas armaduras e danificação induzida pela corrosão devido a três fatores: aumento da concentração de gás carbônico na atmosfera, mudanças de temperatura e mudanças de umidade. Os autores concluem que com as atuais projeções de mudanças climáticas, uma em cada seis estruturas terão aumentos significativos de danificação até 2100, o que se traduz em custos adicionais elevados. Os autores concluem que pequenos aumentos no cobrimento, como 10 ou $5 \mathrm{~mm}$, para estruturas onde a carbonatação ou a penetração de cloretos influenciam fortemente a durabilidade, respectivamente, pode melhorar significativamente os efeitos das mudanças climáticas. Além de um aumento da espessura de cobrimento, pode-se também melhorar a qualidade do concreto e prover barreiras às estruturas ou proteções que reduzam o coeficiente de difusão de agentes agressivos.

Nessa mesma linha de estudos sobre mudanças climáticas e seus efeitos nas estruturas, Bastidas-Arteaga e Stewart (2015) apresentam um estudo com a avaliação de custos e benefícios de duas estratégias de adaptação às alterações climáticas para novas estruturas de concreto armado inseridas em ambientes com presença elevada de cloretos sob vários cenários de mudanças climáticas. A relação custo/eficácia é medida em termos da relação benefício/custo e da probabilidade de que a relação benefício/custo exceda o valor 1. Nos exemplos apresentados, 
os autores concluíram que aumentar o grau de resistência do concreto traz um melhor custobenefício do que aumentar o cobrimento de projeto.

Uma análise probabilística do processo corrosivo envolvendo as etapas de iniciação e propagação é de interesse para uma visão mais ampla da vida útil estrutural. O trabalho apresentado por Tongyan e Lu (2012) se insere nesse contexto, utilizando o método dos elementos finitos para modelar a microestrutura da matriz de concreto e assim prever a vida útil de estruturas de concreto armado envolvendo três etapas: ingresso de agentes químicos danosos, corrosão das armaduras e fissuração do concreto. O modelo de transporte de agentes agressivos considera a aplicação de campos de temperatura, mecânicos e elétricos. O resultado do modelo é comparado com resultados de testes de laboratório para validação e em seguida é aplicado a uma laje de ponte de concreto armado. É utilizada a simulação de Monte Carlo para calcular as probabilidades de aparecimento da primeira fissura. A evolução dessa curva de probabilidades se mostrou extremamente rápida, assumindo valores em torno de $10 \%$ com seis anos e meio de tempo de exposição aos agentes externos agressivos e valores em torno de $50 \%$ com sete anos e meio. Entretanto, os autores não consideraram a concentração limite de cloretos como sendo uma variável aleatória. Por se tratar de um parâmetro bastante incerto, até mesmo em ensaios realizados em laboratório sob condições controladas, desprezar sua aleatoriedade no processo pode conduzir a consideráveis imprecisões na previsão da vida útil estrutural.

Siamphukdee et al. (2013) realizaram uma análise de sensibilidade dos parâmetros de entrada de nove modelos disponíveis na literatura de previsão da taxa de corrosão. Três métodos diferentes de análise foram utilizados: regressão univariada, regressão multivariada e o índice de sensibilidade. Os resultados do estudo mostram quantitativamente que a taxa de corrosão do aço em elementos de concreto armado é altamente sensível ao tempo de duração da corrosão, à resistência do concreto e ao conteúdo de cloretos.

Uma discussão a respeito da definição de um novo estado limite chamado de "estado limite de iniciação de corrosão" é feita por Andrade (2017). A autora questiona os valores de índice de confiabilidade que constam no FIB Model Code 2010. Argumenta se tais valores podem conduzem a dúvidas, pois, por um lado, o nível crítico de cloretos não é um valor fixo e a frente de carbonatação afeta primeiramente a superfície externa da barra, desenvolvendo uma danificação perimetral progressiva e, por outro lado, a consideração do estado limite como um estado limite de serviço (ELS), com uma probabilidade de falha fixa tão baixa, introduz algumas contradições com a clássica definição de ELS. Isso ocorre, pois, embora o ELS seja definido como uma falha em cumprir os requisitos de projeto, qualquer projeto de desempenho estrutural muda no momento da despassivação do aço. Além disso, informações a respeito de como 
considerar a danificação da seção ou que modelo de propagação de corrosão utilizar não são normalmente fornecidos em normas, além de não haver uma definição de como verificar o clássico ELS e o estado limite último (ELU). A autora propõe que se considere um estado limite de iniciação de corrosão, seguindo as diretrizes da norma ISO 2394 e não o valor prescrito do FIB Model Code 2010. O valor adequado da probabilidade de falha à corrosão deve ser dependente das consequências de falha e das taxas de ingresso de cloretos, de carbonatação e da corrosão do aço.

Conforme apresentado anteriormente, a análise do ciclo de vida, a importância da manutenção e inspeção de estruturas para assegurar um dado nível de segurança, análises em uma e duas dimensões do processo de difusão, variabilidade espacial da ação da corrosão ao longo das barras de aço e seus efeitos, a consideração de estados limites últimos de flexão e de cisalhamento, a consideração de estados limites de serviço de fissuração e deslocamentos excessivos, efeitos das variações climáticas no processo de corrosão, entre outros, foram tópicos pesquisados e discutidos ao longo dos últimos 30 anos, realizando-se tanto análises determinísticas quanto análises envolvendo as incertezas dos fenômenos. Contudo, na grande maioria dos trabalhos, métodos analíticos simplificados são utilizados como modelos para prever a evolução da difusão dos íons cloreto no interior do concreto. Assim, por mais refinada que uma análise de confiabilidade possa ser conduzida, adotar um modelo de difusão de cloretos impreciso produz resultados em termos de probabilidade pouco representativos e distantes de uma aplicabilidade prática em projetos. O acoplamento do modelo em elementos de contorno desenvolvido neste trabalho com algoritmos de confiabilidade e otimização se insere neste contexto.

\subsection{Objetivos, metodologia e delimitações}

O objetivo geral desta tese é o desenvolvimento de uma ferramenta computacional capaz de realizar simulações de problemas bidimensionais governados pela equação de difusão de íons cloreto acoplados a algoritmos de confiabilidade e otimização.

Para que o objetivo geral seja alcançado, são elencados a seguir alguns objetivos específicos que foram abordados ao longo do desenvolvimento do trabalho:

- Desenvolver um código computacional baseado na formulação do método dos elementos de contorno para a simulação robusta e precisa da difusão de cloretos no concreto em regime estacionário e transiente em domínios bidimensionais; 
- Quantificar a influência das incertezas presentes no processo de difusão de íons na vida útil de estruturas de concreto armado por meio do acoplamento de algoritmos de confiabilidade ao programa de modelagem da difusão;

- Explorar estratégias para otimização da espessura de cobrimento do concreto a partir do acoplamento de algoritmos de otimização baseada em confiabilidade ao programa de modelagem da difusão;

- Realizar análises críticas e extrair conclusões a partir dos resultados alcançados no presente trabalho e aqueles reportados na literatura.

As contribuições da presente tese são:

- Elaboração de uma ferramenta computacional para a modelagem da difusão de íons cloreto no concreto baseada no método dos elementos de contorno. Tal método numérico não é convencionalmente utilizado na modelagem do fenômeno estudado e apresenta grande potencialidade em comparação com soluções analíticas e com outros métodos numéricos;

- Análises inéditas envolvendo o acoplamento entre o método dos elementos de contorno e algoritmos de confiabilidade para a quantificação dos efeitos das incertezas ao longo do processo de difusão de íons no concreto;

- Resolução de problemas práticos envolvendo a otimização sob incertezas da espessura de cobrimento em estruturas de concreto armado submetidas a penetração de íons cloreto. Tal tipo de análise apresenta um grande potencial de aplicação para a escolha racional e adequada de parâmetros de projeto que visem manter um nível de segurança preestabelecido durante a vida útil estrutural.

As referências bibliográficas foram consultadas em base de dados como a Web of Science, a Scopus e a Science Direct, além de livros disponíveis na biblioteca da EESC-USP. As implementações computacionais foram feitas em ambiente Windows e em linguagem Fortran e também utilizando o software Maple 17. As análises numéricas do capítulo 2 foram realizadas em um computador pessoal com processador Intel i7-4790k de 4.0 GHz e 16 GB de memória RAM, sendo que os tempos de processamento reportados nos exemplos servem apenas de base para verificar a viabilidade do acoplamento com algoritmos de confiabilidade e otimização. As análises dos capítulos 3 e 4 foram realizadas em um Cluster com 12 núcleos de processamento de $2.8 \mathrm{GHz}$ e 48GB de memória RAM. Para a visualização dos resultados foi utilizado o software OriginPro8.

O presente trabalho delimita-se a investigar apenas o período de iniciação da corrosão das armaduras devido à ação de íons cloreto. Portanto, nas simulações numéricas realizadas não se considera o período de propagação, que envolve efeitos como a redução da área de aço das armaduras, a geração de tensões internas devido aos produtos das reações de corrosão e a fissuração. Não é considerada também a atuação de esforços mecânicos e suas interações com o processo de difusão de íons. 


\section{MÉTODO DOS ELEMENTOS DE CONTORNO APLICADO A PROBLEMAS DE DIFUSÃO}

\subsection{Considerações iniciais}

A formulação do método dos elementos de contorno (MEC) pode ser dividida em duas categorias básicas: formulação direta e formulação indireta. A formulação indireta apresenta em alguns pontos falta de correlação com aspectos físicos do problema tratado. Por meio da integração de funções fictícias, que buscam representar as grandezas do problema, obtém-se os parâmetros físicos reais. A falta de significado físico das funções fictícias pode ser contornada por meio da formulação direta. Essa formulação pode ser feita a partir da terceira identidade de Green, usando o teorema de Betti, o princípio dos trabalhos virtuais, entre outros. Alternativamente, é possível formular o problema por meio da técnica de resíduos ponderados, que será a seguir empregada. As vantagens de formular o problema por meio dessa abordagem são:

- Generalidade: favorece uma extensão do método para resolver equações diferenciais parciais mais complexas;

- Combinabilidade: a combinação do MEC com outros métodos numéricos formulados via resíduos ponderados (como o MEF) se torna mais fácil.

A formulação aqui apresentada encontra-se em mais detalhes nos livros de Brebbia et al. (1984), Brebbia e Dominguez (1992), Katsikadelis (2002), Wrobel (2002) e Beer et al. (2008).

\subsection{Regime de difusão estacionário}

\subsubsection{Equações integrais}

A equação de Poisson possui importantes aplicações em vários campos da ciência. Em problemas de engenharia, essa equação possibilita a modelagem de fenômenos relacionados a condutividade térmica, torção livre, condução de substâncias, entre outros. Essa equação pode ser escrita da seguinte forma:

$u_{, i i}+b=0$

em que:

- $u$ é um escalar normalmente denominado potencial, podendo ser por exemplo o valor da temperatura, o empenamento de uma seção transversal sujeita a torção, a concentração de determinada substância, etc. 
- $\quad b$ é um termo de domínio, podendo ser uma fonte interna de calor, um momento torçor, uma fonte interna de determinada substância, etc.

Considerando-se que o termo de domínio seja nulo $(b=0)$, a equação de Poisson é escrita como:

$u_{, i i}=0$

Essa equação recebe o nome de equação de Laplace. As condições de contorno do problema são:

- Essenciais: $u(x)=\bar{u}(x)$ em $\Gamma_{1}$ (condições de contorno de Dirichlet);

- Naturais: $q(x)=\bar{q}(x)=\frac{\partial u(x)}{\partial \eta}$ em $\Gamma_{2}$ (condições de contorno de Neumann).

sendo $\bar{u}(x)$ o valor prescrito de potencial, $\bar{q}(x)$ o valor prescrito de fluxo na direção normal ao contorno, $\Gamma_{1}$ e $\Gamma_{2}$ os contornos respectivos e $\frac{\partial u(x)}{\partial \eta}$ a derivada direcional de $u$ em relação ao vetor $\eta$ normal ao contorno, como mostra a Figura 2.1.

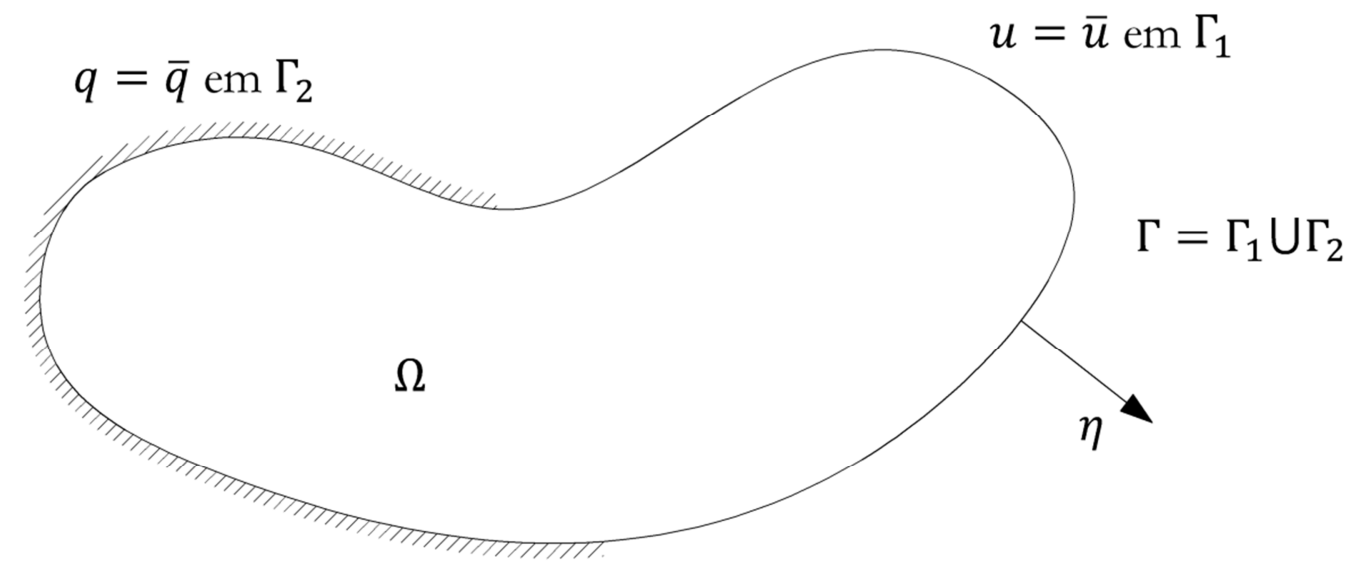

Figura 2.1 - Domínio, contornos e vetor normal a um corpo qualquer

Considerando que $w$ seja uma função não nula e contínua até a segunda derivada (classe C2), tal como $u$, e que $w$ seja uma solução para $u$, multiplica-se $u_{, i i}$ por $w$ sem se importar que $u$ respeite as condições de Laplace ou de Poisson:

$u_{, i i} w=0$

Integrando em todo o domínio $\Omega$ tem-se:

$\int_{\Omega} u_{, i i} w d \Omega=0$

Integrando por partes tem-se:

$\int_{\Omega} u_{, i i} w d \Omega=\int_{\Gamma} u_{, i} \eta_{i} w d \Gamma-\int_{\Omega} u_{, i} w_{, i} d \Omega$ 
Lembrando que $q=\frac{\partial u}{\partial \eta}=u_{, i} \eta_{i}$ pode-se escrever a equação anterior como:

$$
\int_{\Omega} u_{, i i} w d \Omega=\int_{\Gamma} q w d \Gamma-\int_{\Omega} u_{, i} w_{, i} d \Omega
$$

Integrando por partes o segundo termo do lado direito da igualdade tem-se:

$$
\int_{\Omega} u_{, i i} w d \Omega=\int_{\Gamma} q w d \Gamma-\int_{\Gamma} u \eta_{i} w_{, i} d \Gamma+\int_{\Omega} u w_{, i i} d \Omega
$$

Reorganizando os termos acima tem-se:

$$
\begin{aligned}
& \int_{\Omega} u_{, i i} w d \Omega-\int_{\Omega} u w_{, i i} d \Omega=\int_{\Gamma} q w d \Gamma-\int_{\Gamma} u \eta_{i} w_{, i} d \Gamma \rightarrow \\
& \int_{\Omega}\left(u_{, i i} w-u w_{, i i}\right) d \Omega=\int_{\Gamma}\left(q w-u \eta_{i} w_{, i}\right) d \Gamma \rightarrow \\
& \int_{\Omega}\left(u_{, i i} w-u w_{, i i}\right) d \Omega=\int_{\Gamma}\left(\frac{\partial u}{\partial \eta} w-u \frac{\partial w}{\partial \eta}\right) d \Gamma
\end{aligned}
$$

Considerando agora que $w^{*}$ seja uma solução conhecida da equação diferencial:

$$
w_{, i i}^{*}+c=0
$$

onde $c$ possui o mesmo significado de $b$ na Equação (2.1). Como $u$ é solução da Equação (2.1) e sabendo-se que $w^{*}$ e $\frac{\partial w^{*}}{\partial \eta}$ são valores conhecidos no contorno, com as condições de contorno de Dirichlet e Neumann, pode-se reescrever a Equação (2.8) como:

$$
\int_{\Omega}\left(-b w^{*}+u c\right) d \Omega=\int_{\Gamma_{1}} w^{*} \frac{\partial u}{\partial \eta} d \Gamma_{1}+\int_{\Gamma_{2}} w^{*} \frac{\partial \bar{u}}{\partial \eta} d \Gamma_{2}-\int_{\Gamma_{1}} \bar{u} \frac{\partial w^{*}}{\partial \eta} d \Gamma_{1}-\int_{\Gamma_{2}} u \frac{\partial w^{*}}{\partial \eta} d \Gamma_{2}
$$

Sabendo-se que $\frac{\partial u}{\partial \eta}=q$ e $\frac{\partial w^{*}}{\partial \eta}=q^{*}$, pode-se reescrever a Equação (2.10) assim:

$$
\int_{\Omega}\left(-b w^{*}+u c\right) d \Omega=\int_{\Gamma_{1}} w^{*} q d \Gamma_{1}+\int_{\Gamma_{2}} w^{*} \bar{q} d \Gamma_{2}-\int_{\Gamma_{1}} \bar{u} q^{*} d \Gamma_{1}-\int_{\Gamma_{2}} u q^{*} d \Gamma_{2}
$$

sendo que $\bar{q}$ e $\bar{u}$ aparecem com uma barra em cima para indicar que são valores prescritos nos contornos $\Gamma_{2}$ e $\Gamma_{1}$ respectivamente. Na Equação (2.11), $w^{*}$ pode ser interpretada como uma função ponderadora. Assim, posicionando as parcelas desconhecidas do lado esquerdo da igualdade e as parcelas conhecidas do lado direito, tem-se:

$$
\int_{\Omega} u c d \Omega-\int_{\Gamma_{1}} w^{*} q d \Gamma_{1}+\int_{\Gamma_{2}} u q^{*} d \Gamma_{2}=\int_{\Omega} b w^{*} d \Omega-\int_{\Gamma_{1}} \bar{u} q^{*} d \Gamma_{1}+\int_{\Gamma_{2}} w^{*} \bar{q} d \Gamma_{2}
$$


Convenientemente, com o objetivo de eliminar a integral de domínio desconhecida do lado esquerdo, pode-se adotar na Equação (2.9) o termo $C$ como sendo igual à função delta de $\operatorname{Dirac} \delta(\varsigma, x)^{1}$ :

$w_{, i i}^{*}+\delta(\varsigma, x)=0$

sendo $\zeta$ referente ao ponto fonte e $X$ referente ao ponto campo. Assim sendo, a Equação (2.12) pode ser reescrita, explicitando agora a dependência de $\varsigma$ e $x$ como:

$$
\begin{aligned}
\int_{\Omega} u(x) \delta(\varsigma, x) d \Omega-\int_{\Gamma_{1}} w^{*}(\varsigma, x) q(x) d \Gamma_{1}+\int_{\Gamma_{2}} u(x) q^{*}(\varsigma, x) d \Gamma_{2} \\
=\int_{\Omega} b(x) w^{*}(\varsigma, x) d \Omega-\int_{\Gamma_{1}} \bar{u}(x) q^{*}(\varsigma, x) d \Gamma_{1}+\int_{\Gamma_{2}} w^{*}(\varsigma, x) \bar{q}(x) d \Gamma_{2}
\end{aligned}
$$

A Equação (2.14) pode ser manipulada considerando a solução $w^{*}$ descrita na Equação (2.13). Tal solução é conhecida como solução fundamental, uma vez que a Equação (2.13) descreve o problema fundamental. Assim, torna-se necessária a obtenção desta solução, a qual é feita no tópico seguinte.

\subsubsection{Solução fundamental bidimensional}

A função $w^{*}$ a ser utilizada no problema de potencial é uma solução particular da equação de Laplace. Para obter essa solução escreve-se o Laplaciano em coordenadas polares:

$$
\begin{aligned}
& \nabla^{2} u=0=\frac{1}{r} \frac{\partial}{\partial r}\left(r \frac{\partial u}{\partial r}\right)+\frac{1}{r^{2}} \frac{\partial^{2} u}{\partial \theta^{2}}=\frac{1}{r}\left[\frac{\partial u}{\partial r}+r \frac{\partial^{2} u}{\partial \theta^{2}}\right]+\frac{1}{r^{2}} \frac{\partial^{2} u}{\partial \theta^{2}} \rightarrow \\
& \nabla^{2} u=\frac{\partial^{2} u}{\partial r^{2}}+\frac{1}{r} \frac{\partial u}{\partial r}+\frac{1}{r^{2}} \frac{\partial^{2} u}{\partial \theta^{2}}=0
\end{aligned}
$$

A partir da Equação (2.13), chamando $w^{*}$ de $u^{*}$, pode-se escrever:

$$
\nabla^{2} u^{*}+\delta=0 \rightarrow \frac{\partial^{2} u^{*}}{\partial r^{2}}+\frac{1}{r} \frac{\partial u^{*}}{\partial r}+\frac{1}{r^{2}} \frac{\partial^{2} u^{*}}{\partial \theta^{2}}+\delta=0
$$

Adotando a origem do problema fundamental como sendo o ponto fonte, a solução $u^{*}$ se torna independente de $\theta$. Assim, a Equação (2.16) torna-se:

$$
\frac{\partial^{2} u^{*}}{\partial r^{2}}+\frac{1}{r} \frac{\partial u^{*}}{\partial r}+\delta=0
$$

Deve-se observar que essa equação só é definida para $r \neq 0$ e para $\varsigma \neq x$. Portanto $\delta(\varsigma, x)=0$, assim:

\footnotetext{
${ }^{1}$ A definição e as propriedades do delta de Dirac podem ser consultadas no Anexo A da presente tese.
} 
$\frac{\partial^{2} u^{*}}{\partial r^{2}}+\frac{1}{r} \frac{\partial u^{*}}{\partial r}=0 \quad$ para $r \neq 0$

Contudo, a solução deve contemplar também o caso onde $r=0$. A solução da Equação (2.18) é do tipo $a \ln \left(\frac{1}{r}\right)=-a \ln (r)$. Verificando essa solução, tem-se:

$\frac{\partial^{2}}{\partial r^{2}}(-a \ln (r))+\frac{1}{r} \frac{\partial}{\partial r}(-a \ln (r))=\frac{a}{r^{2}}+\frac{1}{r}\left(-\frac{a}{r}\right)=0$

Para determinar-se o termo independente $a$ deve-se integrar a Equação (2.16). Assim:

$$
\begin{aligned}
& \int_{\Omega}\left(\nabla^{2} u^{*}+\delta\right) d \Omega=0 \rightarrow \int_{\Omega} \nabla^{2} u^{*} d \Omega+\int_{\Omega} \delta d \Omega=0 \rightarrow \\
& \int_{\Omega} \nabla^{2} u^{*} d \Omega+1=0 \rightarrow \int_{\Omega} \nabla^{2} u^{*} d \Omega=-1
\end{aligned}
$$

Utilizando o teorema de Green, tem-se:

$$
\int_{\Omega} \nabla^{2} u^{*} d \Omega=-1 \rightarrow \int_{\Gamma} u_{, i}^{*} \eta_{i} d \Gamma=-1 \rightarrow \int_{\Gamma} \frac{\partial u^{*}}{\partial \eta} d \Gamma=-1
$$

Tomando um contorno circular de raio arbitrário como o contorno da linha equipotencial, tem-se:

$$
\frac{\partial u^{*}}{\partial \eta}=\frac{\partial u^{*}}{\partial r}
$$

Como $u^{*}=-a \ln (r)$, tem-se:

$$
\frac{\partial u^{*}}{\partial r}=-\frac{a}{r}
$$

Considerando que um comprimento infinitesimal do contorno possa ser escrito por $d \Gamma=r d \theta$, tem-se na Equação (2.21):

$$
\int_{\Gamma} \frac{\partial u^{*}}{\partial \eta} d \Gamma=-1 \rightarrow \int_{0}^{2 \pi}\left(-\frac{a}{r}\right) r d \theta=-1 \rightarrow-a 2 \pi=-1 \rightarrow a=\frac{1}{2 \pi}
$$

Destaca-se que a última integral não depende de $x$ e portanto é valida para $r=0$. Assim sendo, a solução do problema fundamental para o caso bidimensional é:

$$
u^{*}=\frac{1}{2 \pi} \ln \left(\frac{1}{r}\right)=-\frac{1}{2 \pi} \ln (r)
$$

A derivada da solução fundamental é dada por:

$$
\frac{\partial u^{*}}{\partial x_{i}}=u_{, i}^{*}=-\frac{1}{2 \pi r} r_{, i}
$$

Tem-se portanto que: 
$q^{*}=u_{, i}^{*} \eta_{i}=-\frac{1}{2 \pi r} r_{, i} \eta_{i}=-\frac{1}{2 \pi r} \frac{\partial r}{\partial \eta}$

Sendo, no caso bidimensional, $\frac{\partial r}{\partial \eta}=r_{, 1} \eta_{1}+r_{, 2} \eta_{2}$. Para que o método seja preciso, os pontos fonte devem estar posicionados sobre o contorno. Assim procedendo, será necessário efetuar o tratamento das integrais singulares que surgirem. Tal tratamento é descrito mais adiante.

\subsubsection{Determinação do termo livre}

Tomando a Equação (2.14) considerando $w^{*}(\varsigma, x)=u^{*}(\varsigma, x)$ :

$$
\begin{aligned}
& \int_{\Omega} u(x) \delta(\varsigma, x) d \Omega-\int_{\Gamma_{1}} u^{*}(\varsigma, x) q(x) d \Gamma_{1}+\int_{\Gamma_{2}} u(x) q^{*}(\varsigma, x) d \Gamma_{2} \\
&=\int_{\Omega} b(x) u^{*}(\varsigma, x) d \Omega-\int_{\Gamma_{1}} \bar{u}(x) q^{*}(\varsigma, x) d \Gamma_{1}+\int_{\Gamma_{2}} u^{*}(\varsigma, x) \bar{q}(x) d \Gamma_{2}
\end{aligned}
$$

Agrupando as integrais da equação anterior tem-se:

$$
\begin{aligned}
\int_{\Omega} u(x) \delta(\varsigma, x) d \Omega+\int_{\Gamma} u(x) q^{*}(\varsigma, x) d \Gamma \\
=\int_{\Omega} b(x) u^{*}(\varsigma, x) d \Omega+\int_{\Gamma} q(x) u^{*}(\varsigma, x) d \Gamma
\end{aligned}
$$

Para o caso em que o ponto fonte, no problema de Laplace, encontra-se dentro do domínio, a equação anterior é escrita como:

$u(\varsigma)+\int_{\Gamma} u(x) q^{*}(\varsigma, x) d \Gamma=\int_{\Omega} b(x) u^{*}(\varsigma, x) d \Omega+\int_{\Gamma} q(x) u^{*}(\varsigma, x) d \Gamma$

Essa equação é válida para pontos localizados no domínio. Para pontos localizados sobre o contorno deve-se estudar o comportamento da Equação (2.30) quando $\varepsilon$ tender a zero, conforme apresentado na Figura 2.2.

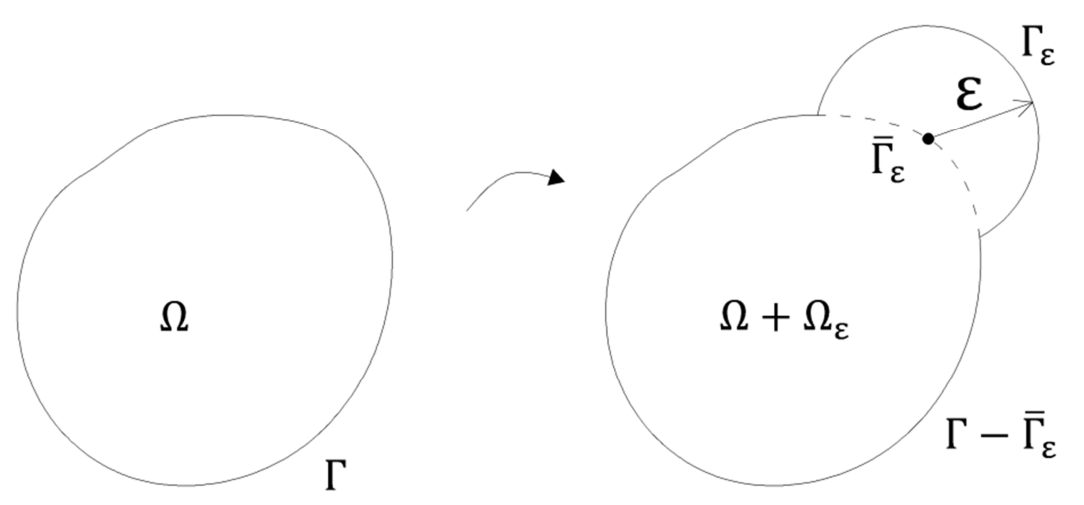

Figura 2.2 - Análise limite de pontos sobre o contorno 
Entende-se que o ponto fonte é pertencente ao domínio delimitado por $\Gamma-\bar{\Gamma}_{\varepsilon}+\Gamma_{\varepsilon}$, ou seja, ao domínio $\Omega+\Omega_{\varepsilon}$, porém está sobre o contorno do domínio real $\Omega$ delimitado por $\Gamma=\Gamma-\bar{\Gamma}_{\varepsilon}+\bar{\Gamma}_{\varepsilon}$. Sendo $\varepsilon$ arbitrário pode-se fazer:

$\Gamma=\lim _{\varepsilon \rightarrow 0}\left(\Gamma-\bar{\Gamma}_{\varepsilon}+\Gamma_{\varepsilon}\right)$

$\Omega=\lim _{\varepsilon \rightarrow 0}\left(\Omega+\Omega_{\varepsilon}\right)$

Dessa forma a Equação (2.30) é analisada por um processo limite:

$\lim _{\varepsilon \rightarrow 0}\left[u(\varsigma)+\int_{\Gamma-\bar{\Gamma}_{\varepsilon}+\Gamma_{\varepsilon}} u(x) q^{*}(\varsigma, x) d \Gamma=\int_{\Omega+\Omega_{\varepsilon}} b(x) u^{*}(\varsigma, x) d \Omega+\int_{\Gamma-\bar{\Gamma}_{\varepsilon}+\Gamma_{\varepsilon}} q(x) u^{*}(\varsigma, x) d \Gamma\right]$

O limite da Equação (2.32) será analisado considerando cada termo individualmente. Analisando o termo de domínio, tem-se:

$\int_{\Omega+\Omega_{\varepsilon}} b(x) u^{*}(\varsigma, x) d \Omega=\int_{\Omega} b(x) u^{*}(\varsigma, x) d \Omega+\int_{\Omega_{\varepsilon}} b(x) u^{*}(\varsigma, x) d \Omega_{\varepsilon}$

A primeira integral do lado direito da desigualdade não se altera quando $\varepsilon \rightarrow 0$. Já a segunda integral do lado direito da igualdade é avaliada conforme:
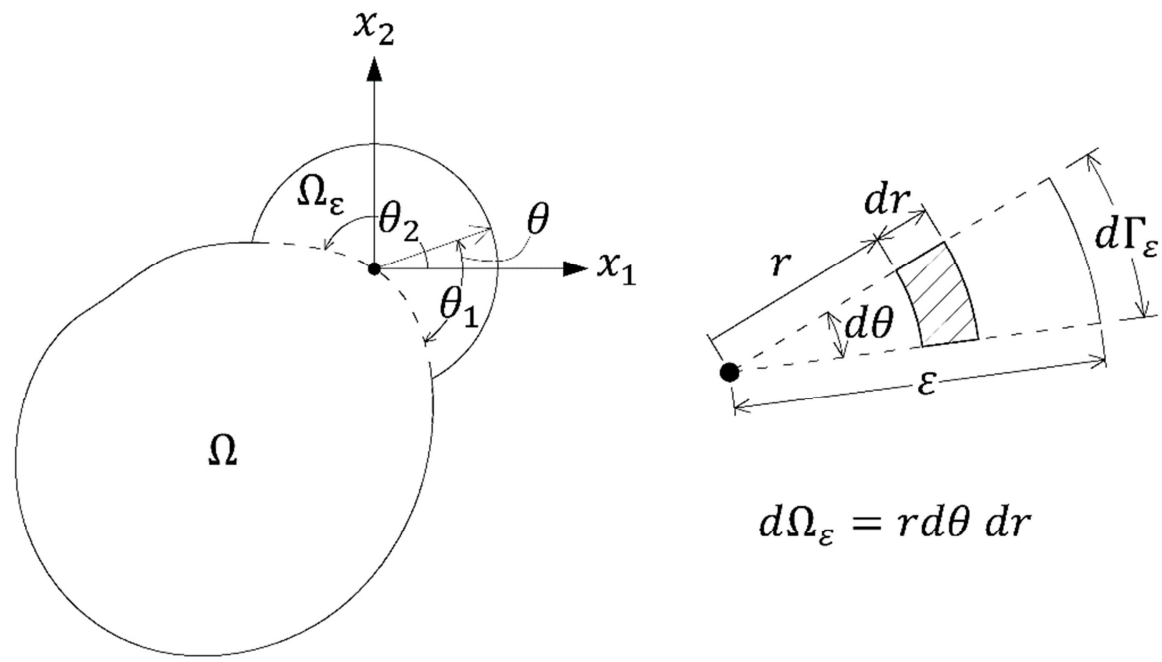

$$
d \Omega_{\varepsilon}=r d \theta d r
$$

Figura 2.3 - Esquema ilustrativo da análise limite para a integral contendo o termo de domínio

$$
\int_{\Omega_{\varepsilon}} u^{*}(\varsigma, x) b(x) d \Omega_{\varepsilon}=-\frac{1}{2 \pi} \int_{-\theta_{1}}^{\theta_{2}} \int_{0}^{\varepsilon} \ln (r) b(r, \theta) r d r d \theta
$$

A função $b(r, \theta)$ é limitada e não singular, portanto:

$$
\int_{\Omega_{\varepsilon}} u^{*}(\varsigma, x) b(x) d \Omega_{\varepsilon}=-\frac{1}{2 \pi}\left[F\left(\theta_{2}\right)-F\left(-\theta_{1}\right)\right] \int_{0}^{\varepsilon} \ln (r) b(r) r d r
$$

Assim, resolvendo a integral de 0 a $\varepsilon$ : 


$$
\int_{0}^{\varepsilon} \ln (r) b(r) r d r=\left.[F(b, \varepsilon)-F(b, 0)] \frac{1}{4} r^{2}[\ln (r)-1]\right|_{0} ^{\varepsilon}=[F(b, \varepsilon)-F(b, 0)] \frac{1}{4}\left[\varepsilon^{2} \ln (\varepsilon)-\varepsilon^{2}\right]
$$

No limite, quando $\varepsilon \rightarrow 0$, os termos entre colchetes dependentes de $\varepsilon$ são analisados conforme segue:

$\lim _{\varepsilon \rightarrow 0}\left[\varepsilon^{2} \ln (\varepsilon)\right]=\lim _{\varepsilon \rightarrow 0}\left[\frac{\frac{\ln (\varepsilon)}{1}}{\frac{1}{\varepsilon^{2}}}\right]=\lim _{\varepsilon \rightarrow 0}\left[\frac{\frac{1}{\varepsilon}}{-\frac{2}{\varepsilon^{2}}}\right]=\lim _{\varepsilon \rightarrow 0}\left[\frac{-\varepsilon^{3}}{2 \varepsilon}\right]=\lim _{\varepsilon \rightarrow 0}\left[\frac{-\varepsilon^{2}}{2}\right]=0$

$\lim _{\varepsilon \rightarrow 0}\left[-\varepsilon^{2}\right]=0$

Portanto, o limite do termo de domínio da Equação (2.32) resulta:

$\lim _{\varepsilon \rightarrow 0}\left[\int_{\Omega+\Omega_{\varepsilon}} b(x) u^{*}(\varsigma, x) d \Omega\right]=\int_{\Omega} b(x) u^{*}(\varsigma, x) d \Omega$

Analisando agora o termo de integral de contorno relacionado a $u^{*}$ na Equação (2.32), tem-se:

$\int_{\Gamma-\bar{\Gamma}_{\varepsilon}+\Gamma_{\varepsilon}} q(x) u^{*}(\varsigma, x) d \Gamma=\int_{\Gamma-\bar{\Gamma}_{\varepsilon}} q(x) u^{*}(\varsigma, x) d \Gamma+\int_{\Gamma_{\varepsilon}} q(x) u^{*}(\varsigma, x) d \Gamma$

A primeira integral do lado direito da igualdade não se altera quando $\varepsilon \rightarrow 0$ pois a mesma não depende de $\varepsilon$. Já a segunda integral do lado direito da igualdade é avaliada conforme:
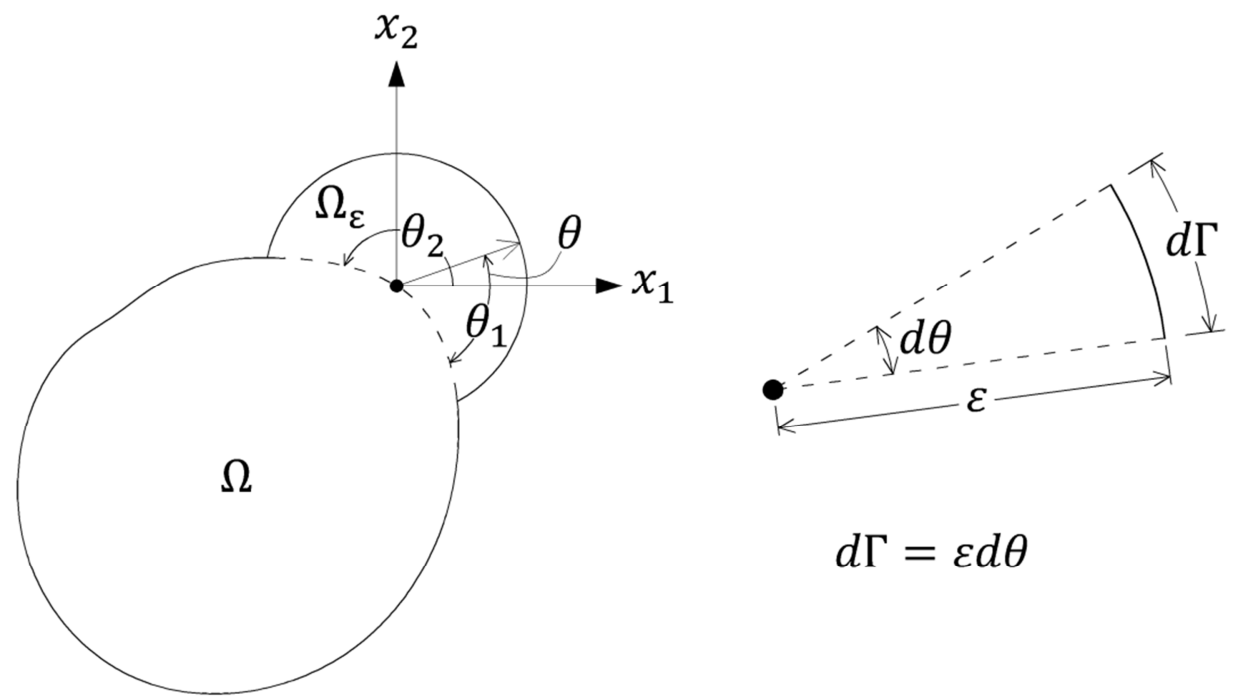

$$
d \Gamma=\varepsilon d \theta
$$

Figura 2.4 - Esquema ilustrativo da análise limite para a integral contendo $u^{*}$

$$
\int_{\Gamma_{\varepsilon}} q(x) u^{*}(\varsigma, x) d \Gamma=\int_{-\theta_{1}}^{\theta_{2}}-\frac{1}{2 \pi} \ln (\varepsilon) q(\varepsilon, \theta) \varepsilon d \theta=\int_{-\theta_{1}}^{\theta_{2}}-\frac{\varepsilon}{2 \pi} \ln (\varepsilon) q(\varepsilon, \theta) d \theta
$$

A função $q(\varepsilon, \theta)$ é limitada e não singular, portanto: 


$$
\int_{\Gamma_{\varepsilon}} q(x) u^{*}(\varsigma, x) d \Gamma=-\frac{1}{2 \pi}\left[F\left(\theta_{2}\right)-F\left(-\theta_{1}\right)\right][\varepsilon \ln (\varepsilon) q(\varepsilon)]
$$

No limite, quando $\varepsilon \rightarrow 0$, pelo teorema de L'Hôpital, os termos entre colchetes dependentes de $\varepsilon$ tendem a zero. Assim, a análise do limite dessa parcela resulta em:

$$
\lim _{\varepsilon \rightarrow 0}\left[\int_{\Gamma-\bar{\Gamma}_{\varepsilon}+\Gamma_{\varepsilon}} q(x) u^{*}(\varsigma, x) d \Gamma\right]=\lim _{\varepsilon \rightarrow 0}\left[\int_{\Gamma-\bar{\Gamma}_{\varepsilon}} q(x) u^{*}(\varsigma, x) d \Gamma\right]=\int_{\Gamma} q(x) u^{*}(\varsigma, x) d \Gamma
$$

A última integral da Equação (2.42) deverá ser calculada no sentido do valor principal de Cauchy, de maneira a considerar os valores singulares. Por fim, o termo de integral relacionado a $q^{*}$ na Equação (2.32) é analisado conforme:

$$
\int_{\Gamma-\bar{\Gamma}_{\varepsilon}+\Gamma_{\varepsilon}} u(x) q^{*}(\varsigma, x) d \Gamma=\int_{\Gamma-\bar{\Gamma}_{\varepsilon}} u(x) q^{*}(\varsigma, x) d \Gamma+\int_{\Gamma_{\varepsilon}} u(x) q^{*}(\varsigma, x) d \Gamma
$$

Novamente, a primeira integral do lado direito da igualdade não tem influência quando $\varepsilon \rightarrow 0$, pois a mesma não depende de $\varepsilon$. Já o limite da segunda integral do lado direito da igualdade é analisada adicionando e subtraindo um termo constante, conforme a seguir:

$$
\begin{array}{r}
\lim _{\varepsilon \rightarrow 0}\left\{\int_{\Gamma_{\varepsilon}} u(x) q^{*}(\varsigma, x) d \Gamma\right\}=\lim _{\varepsilon \rightarrow 0}\left\{\int_{\Gamma_{\varepsilon}} q^{*}(\varsigma, x)[u(x)+u(\varsigma)-u(\varsigma)] d \Gamma\right\} \\
=\lim _{\varepsilon \rightarrow 0}\left\{\int_{\Gamma_{\varepsilon}} q^{*}(\varsigma, x)[u(x)-u(\varsigma)] d \Gamma+\int_{\Gamma_{\varepsilon}} q^{*}(\varsigma, x) u(\varsigma) d \Gamma\right\}
\end{array}
$$

Realizando-se a mudança de domínio de integração e lembrando que $q^{*}(\varsigma, x)=-\frac{1}{2 \pi r} \frac{\partial r}{\partial \eta}$ ou, alternativamente, $q^{*}(\varepsilon, \theta)=-\frac{1}{2 \pi \varepsilon} \frac{\partial \varepsilon}{\partial \eta}$ :

$$
\lim _{\varepsilon \rightarrow 0}\left\{\int_{-\theta_{1}}^{\theta_{2}}-\frac{1}{2 \pi \varepsilon} \frac{\partial \varepsilon}{\partial \eta}[u(x)-u(\varsigma)] \varepsilon d \theta+\int_{-\theta_{1}}^{\theta_{2}}-\frac{1}{2 \pi \varepsilon} \frac{\partial \varepsilon}{\partial \eta} u(\varsigma) \varepsilon d \theta\right\}
$$

Como no contorno adicionado $\left(\bar{\Gamma}_{\varepsilon}\right)$ tem-se que $\varepsilon$ é paralelo a $\eta$, resulta que $\frac{\partial \varepsilon}{\partial \eta}=1$, assim:

$$
\lim _{\varepsilon \rightarrow 0}\left\{\int_{-\theta_{1}}^{\theta_{2}}-\frac{1}{2 \pi}[u(x)-u(\varsigma)] d \theta+\int_{-\theta_{1}}^{\theta_{2}}-\frac{1}{2 \pi} u(\varsigma) d \theta\right\}
$$

Assumindo que a primeira integral atenda à condição de continuidade de Hölder, ou seja,

$$
|u(x)-u(\varsigma)|<\varepsilon^{\alpha} \operatorname{com} \alpha>1, \text { então: }
$$$$
-\left[F\left(\theta_{2}\right)-F\left(-\theta_{1}\right)\right] \varepsilon^{\alpha} \leq \int_{-\theta_{1}}^{\theta_{2}}[u(x)-u(\varsigma)] d \theta \leq\left[F\left(\theta_{2}\right)-F\left(-\theta_{1}\right)\right] \varepsilon^{\alpha}
$$

Assim, quando $\varepsilon \rightarrow 0$, o limite da primeira integral da Equação (2.46) resulta igual a zero. Portanto, o limite dado pela Equação (2.44) resulta: 


$$
\begin{aligned}
\lim _{\varepsilon \rightarrow 0}\left\{\int_{\Gamma_{\varepsilon}} u(x) q^{*}(\varsigma, x) d \Gamma\right\} & =\lim _{\varepsilon \rightarrow 0}\left\{\int_{\Gamma_{\varepsilon}} q^{*}(\varsigma, x) u(\varsigma) d \Gamma\right\} \\
= & \lim _{\varepsilon \rightarrow 0}\left\{\int_{-\theta_{1}}^{\theta_{2}}-\frac{1}{2 \pi} u(\varsigma) d \theta\right\}=-\frac{1}{2 \pi}\left(\theta_{2}+\theta_{1}\right) u(\varsigma)
\end{aligned}
$$

Assim, analisando-se o limite da Equação (2.43) tem-se:

$\lim _{\varepsilon \rightarrow 0}\left\{\int_{\Gamma-\bar{\Gamma}_{\varepsilon}+\Gamma_{\varepsilon}} u(x) q^{*}(\varsigma, x) d \Gamma\right\}=\int_{\Gamma} u(x) q^{*}(\varsigma, x) d \Gamma-\frac{1}{2 \pi}\left(\theta_{2}+\theta_{1}\right) u(\varsigma)$

A primeira integral do lado direito da igualdade na Equação (2.49) deverá ser calculada no sentido do valor principal de Cauchy, de maneira a considerar os valores singulares. Portanto, para pontos sobre o contorno, pode-se escrever a seguinte equação integral, a partir da Equação (2.32):

$u(\varsigma)-\left(\frac{\theta_{2}+\theta_{1}}{2 \pi}\right) u(\varsigma)+\int_{\Gamma} q^{*}(\varsigma, x) u(x) d \Gamma=\int_{\Gamma} u^{*}(\varsigma, x) q(x) d \Gamma+\int_{\Omega} u^{*}(\varsigma, x) b(x) d \Omega$

Os termos contendo $u(\varsigma)$ dão origem ao chamado termo livre $c(\varsigma)$. Assim, pode-se escrever que:

$u(\varsigma)\left[1-\left(\frac{\theta_{2}+\theta_{1}}{2 \pi}\right)\right] \rightarrow 1-\left(\frac{\theta_{2}+\theta_{1}}{2 \pi}\right)=c(\varsigma)=1-\frac{\theta}{2 \pi}=\frac{2 \pi-\theta}{2 \pi}=\frac{\phi}{2 \pi}$

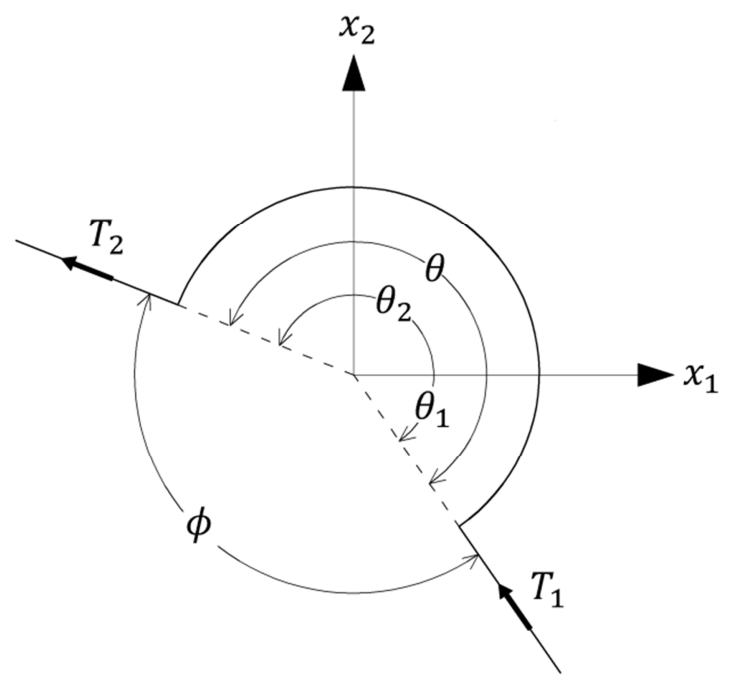

Figura 2.5 - Esquema ilustrativo dos ângulos da Equação (2.51)

Portanto o temo livre para o problema singular é $c(\varsigma)=\frac{\phi}{2 \pi}$. Caso o contorno seja suave, conforme ilustrado na Figura 2.6, $\phi \cong \pi$ e $\operatorname{logo} c(\varsigma)=\frac{1}{2}$. 


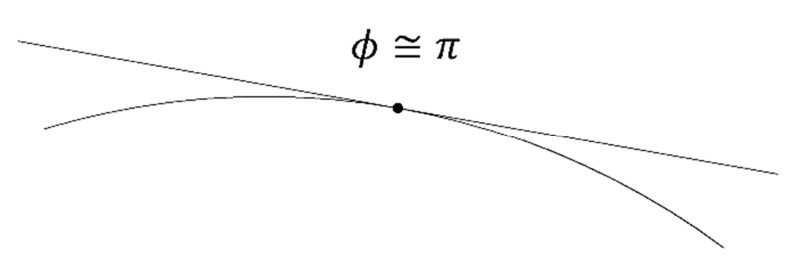

Figura 2.6 - Ilustração de contorno suave para avaliação do termo livre

Conforme ilustrado na Figura 2.5 pode-se fazer:

$\cos (\phi)=\frac{-T_{1} T_{2}}{\left|\overrightarrow{T_{1}}\right|\left|\overrightarrow{T_{2}}\right|}\left\{\begin{array}{c}\text { se } 0 \leq \cos (\phi) \leq 1 \rightarrow 0 \leq \phi \leq \frac{\pi}{2} \\ \text { se }-1 \leq \cos (\phi) \leq 0 \rightarrow \frac{\pi}{2} \leq \phi \leq \pi\end{array}\right.$

sendo $T_{1}$ e $T_{2}$ os vetores tangentes ilustrados na Figura 2.5. Entretanto, também deve-se avaliar $\operatorname{sen}(\theta)=\frac{\left|T_{1} \times T_{2}\right|}{\left|\overrightarrow{T_{1}}\right|\left|\overrightarrow{T_{2}}\right|}$ para saber o ângulo correto desse modo. Assim, a forma geral da Equação (2.29) é:

$c(\varsigma) u(\varsigma)+\int_{\Gamma} q^{*}(\varsigma, x) u(x) d \Gamma=\int_{\Gamma} u^{*}(\varsigma, x) q(x) d \Gamma+\int_{\Omega} u^{*}(\varsigma, x) b(x) d \Omega$

em que:

$c(\varsigma)=1 \quad$ se o ponto fonte estiver interno ao contorno

$c(\varsigma)=0 \quad$ se o ponto fonte estiver externo ao contorno

$c(\varsigma)=1 / 2$ se o ponto fonte estiver sobre um contorno suave

\subsubsection{Introdução das funções de aproximação}

\subsubsection{Aproximações no contorno}

São utilizados polinômios aproximadores de Lagrange para a representação tanto da geometria quanto das grandezas do problema, ambas no contorno. Esses polinômios são definidos em função de uma variável adimensional $\xi$ que assume valores entre -1 e +1 . Um polinômio de Lagrange que interpola $n$ pontos de uma curva possuirá um grau de ordem $n-1$. Cada ponto $i$ dos $n$ pontos possuirá um polinômio $\phi_{i}(\xi)$ associado. Os polinômios são definidos conforme:

$$
\phi_{i}(\xi)=\prod_{\substack{i=1 \\ j=1 \\ i \neq j}}^{n} \frac{\xi-\xi_{j}}{\xi_{i}-\xi_{j}}
$$

As funções $\phi_{i}(\xi)$ são chamadas funções de forma. Pode-se ilustrar a transformação entre espaços, no caso de um polinômio do segundo grau, conforme mostrado na Figura 2.7. 


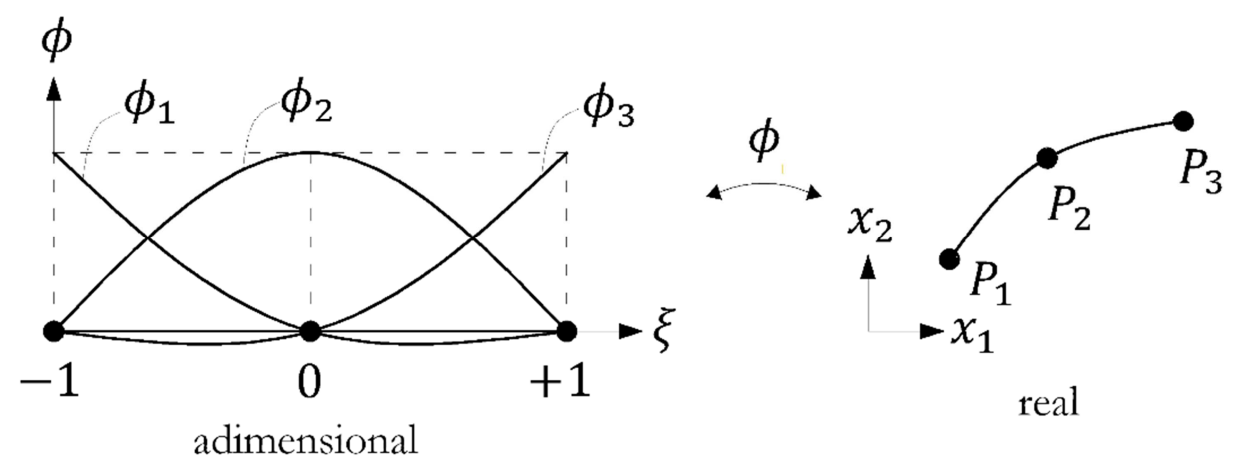

Figura 2.7 - Transformação entre o espaço adimensional e o espaço real

Os pontos $P_{i}$ no espaço real devem ser conhecidos para a parametrização da curva. Uma vez parametrizada a curva, quaisquer pontos pertencentes a essa curva no espaço real podem ser obtidos da seguinte forma:

$x(\xi)=\phi_{j} x_{j}$

Vetores tangentes podem ser obtidos por meio da seguinte expressão:

$T(\xi)=\phi_{i, \xi}(\xi) x_{i}$

As derivadas das funções de forma em relação as coordenadas adimensionais podem ser calculadas por meio da seguinte fórmula recursiva:

$\phi_{i, \xi}(\xi)=\sum_{\substack{i=1 \\ j=1 \\ j \neq i}}^{n} \frac{1}{\xi_{i}-\xi_{j}} \prod_{\substack{k \neq i \\ k \neq j}}^{n} \frac{\xi-\xi_{k}}{\xi_{i}-\xi_{k}}$

As componentes do vetor normal ao contorno podem ser calculadas a partir do conhecimento dos vetores tangentes conforme:

$\vec{\eta}=\frac{T_{2}(\xi)}{\left|\sqrt{T_{1}^{2}+T_{2}^{2}}\right|} i+\frac{-T_{1}(\xi)}{\left|\sqrt{T_{1}^{2}+T_{2}^{2}}\right|} j$

Enfatiza-se que o contorno deverá ser definido e percorrido sempre num sentido tal que o domínio em análise esteja localizado à esquerda do sentido de discretização do contorno, conforme ilustrado na Figura 2.8. Assim procedendo, assegura-se que o vetor normal a um ponto qualquer esteja sempre orientado para fora do domínio. 


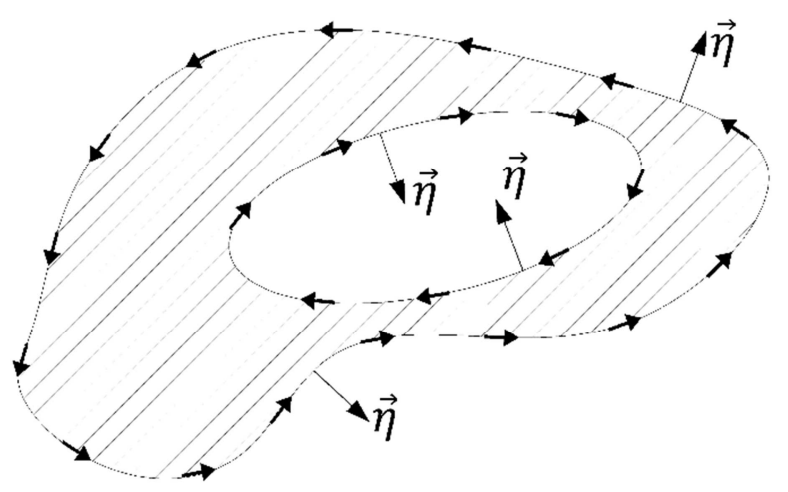

Figura 2.8 - Sentido a ser percorrido no contorno

Outra transformação de interesse se relaciona a calcular o comprimento infinitesimal de uma curva no espaço real, $d \Gamma$, em função do comprimento dessa mesma curva no espaço adimensional, $d \xi$. Para tanto, considere a seguinte relação no espaço real:

$d \Gamma=\sqrt{d x_{1}^{2}+d x_{2}^{2}}$

Reescrevendo a Equação (2.59) com base na definição de vetor tangente tem-se:

$d \Gamma=\sqrt{\left(\frac{d \phi}{d \xi} x_{1}\right)^{2}+\left(\frac{d \phi}{d \xi} x_{2}\right)^{2}} d \xi=\sqrt{T_{1}^{2}+T_{2}^{2}} d \xi$

Assim define-se:

$J=\sqrt{T_{1}^{2}+T_{2}^{2}}$

Sendo J chamado de Jacobiano de transformação de coordenadas. Por exemplo, para avaliar uma integral de uma função $f\left(x_{1}, x_{2}\right)$ em $d \xi$ mas que é escrita originalmente em $d \Gamma$ pode-se fazer:

$\int_{\Gamma} f\left(x_{1}, x_{2}\right) d \Gamma=\int_{-1}^{1} f\left(x_{1}(\xi), x_{2}(\xi)\right) J(\xi) d \xi$

\subsubsection{Aproximação e integração numérica da equação integral}

Até o momento nenhuma aproximação foi introduzida nas equações integrais aqui descritas. O MEC se inicia a partir da introdução de certas aproximações nas equações integrais. Considerando que o termo de domínio seja nulo, ou seja, $b=0$, a Equação (2.53) é reescrita conforme:

$c(\varsigma) u(\varsigma)+\int_{\Gamma} q^{*}(\varsigma, x) u(x) d \Gamma=\int_{\Gamma} u^{*}(\varsigma, x) q(x) d \Gamma$ 
No problema específico da difusão de cloretos no concreto, considerar o termo de domínio igual a zero significa não considerar que no domínio exista uma fonte geradora de cloretos. Em outras palavras, considera-se que o concreto apresente uma concentração de cloretos nula em seu interior logo após sua moldagem. Caso o termo de domínio for considerado diferente de zero basta utilizar o método da reciprocidade dual para o tratamento da integral de domínio. Tal procedimento evita a discretização por células.

Introduzindo-se na Equação (2.63) as aproximações anteriormente descritas tem-se:

$c(\varsigma) u(\varsigma)+\int_{-1}^{1} q^{*}(\varsigma, x) u(\xi) \phi(\xi) J(\xi) d \xi=\int_{-1}^{1} u^{*}(\varsigma, x) q(\xi) \phi(\xi) J(\xi) d \xi$

As integrais acima são avaliadas numericamente por meio da quadratura de GaussLegendre. Dessa forma, as integrais em $q^{*}$ e $u^{*}$ são reescritas, resultando em:

$c_{i}(\varsigma) u_{i}(\varsigma)+\sum_{j=1}^{N E} \sum_{l=1}^{N G} q_{i}^{j^{*}}(\xi) u_{i}(\xi) \phi_{j}(\xi) J(\xi) w_{l}=\sum_{j=1}^{N E} \sum_{l=1}^{N G} u_{i}^{j^{*}}(\xi) q_{i}(\xi) \phi_{j}(\xi) J(\xi) w_{l}$

$\mathrm{Na}$ Equação (2.65) $N E$ é o número total de elementos utilizado na discretização do contorno, $N G$ é o número de pontos de Gauss (ou pontos de integração) de cada elemento, $i$ é o índice do nó fonte, $j$ é o contador do número do elemento, $l$ é o contador do número do ponto de Gauss e $w_{l}$ é o peso que um ponto de Gauss possui.

\subsubsection{Elementos de contorno descontínuos}

Em elementos de contorno descontínuos os nós de extremidade, localizados nas coordenadas adimensionais $\xi= \pm 1$ são suavemente transladados para o interior do elemento. Procedendo dessa maneira é possível prescrever grandezas distintas no contorno (no caso, fluxo ou potencial) em elementos adjacentes sem que ocorra uma descontinuidade no campo dessas grandezas ao longo do contorno. A Figura 2.9 ilustra essa suave translação.

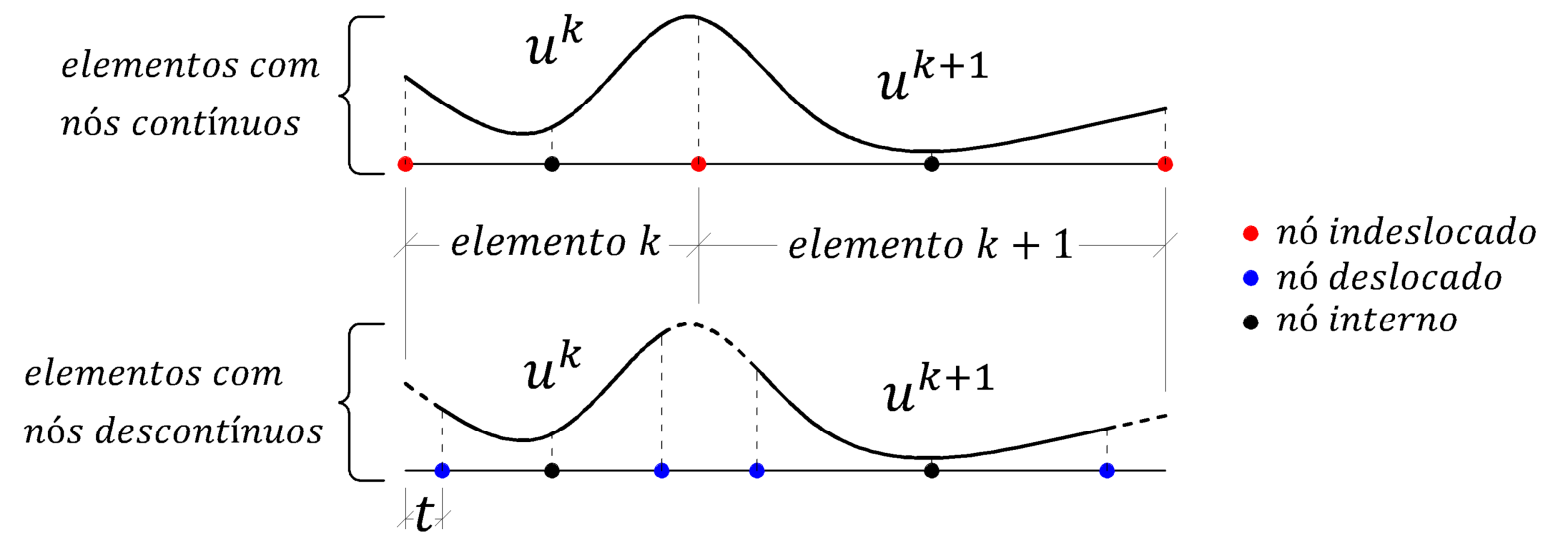

Figura 2.9 - Translação dos nós fonte adjacentes a um mesmo elemento para o interior dos elementos 
Outra vantagem na utilização de elementos de contorno descontínuos diz respeito a casos em que o contorno não possui curvatura suave, conforme ilustrado na Figura 2.10. Nessa situação os nós da interseção entre os elementos são afastados do ponto de curvatura não suave, evitando a necessidade de calcular um termo livre $c(\varsigma)$ diferente de $1 / 2$.

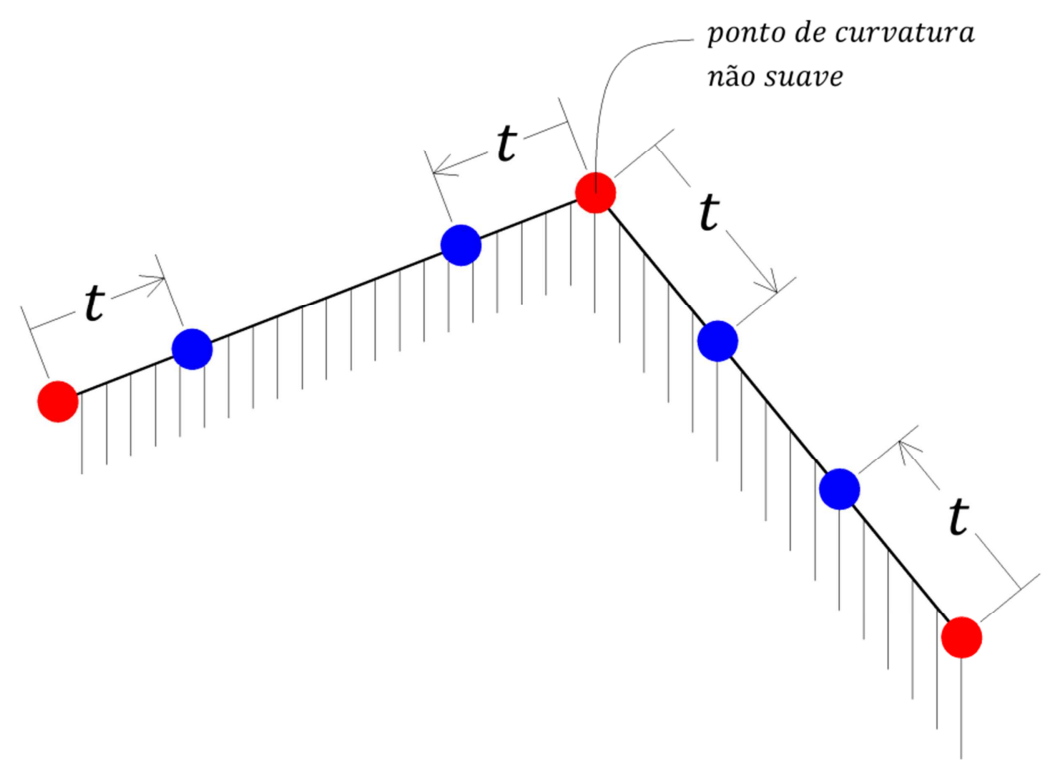

Figura 2.10 - Translação dos nós fonte adjacentes a um mesmo elemento em contornos não suaves

Nesse trabalho optou-se por discretizar o contorno dos problemas utilizando apenas elementos descontínuos, devido as vantagens apresentadas. A translação $t$ de nós adjacentes para o interior do elemento é feita no espaço adimensional e, em seguida, as coordenadas dos nós adimensionais são transformadas para o espaço real. O valor arbitrado para $t$ é igual a $25 \%$ da distância adimensional entre o nó de extremidade e o nó seguinte pertences ao mesmo elemento.

\subsubsection{Subtração de singularidade}

A medida que o ponto fonte aproxima-se do ponto campo os núcleos integrais, que contém as soluções fundamentais, tendem a se tornar singulares. Em outras palavras, quando a distância $r$ entre os pontos fonte e campo tende a zero, os núcleos integrais tendem a assumir valores infinitos. Quando isto ocorre, podem ser utilizados esquemas especiais de integração como o método da subtração de singularidade. Sendo $\xi_{0}$ a coordenada adimensional do ponto fonte e $\xi$ a coordenada adimensional do ponto campo, a distância real entre esses dois pontos, $r$, pode ser calculada utilizando uma expansão em série de Taylor:

$r=\sqrt{\left[x_{i}(\xi)-x_{i}\left(\xi_{0}\right)\right]^{2}}=\sqrt{\left[x_{i}\left(\xi_{0}\right)+x_{i, \xi}\left(\xi_{0}\right) \varepsilon-x_{i}\left(\xi_{0}\right)\right]^{2}}=\sqrt{\left[x_{i, \xi}\left(\xi_{0}\right) \varepsilon\right]^{2}}$

em que: 
$x_{i}\left(\xi_{0}\right)=\phi_{i}\left(\xi_{0}\right) x_{i} \rightarrow x_{, i}\left(\xi_{0}\right)=\phi_{, i}\left(\xi_{0}\right) x_{i}$

Sabendo que o Jacobiano é dado por $J=\sqrt{\left[\phi_{, i}\left(\xi_{0}\right) x_{i}\right]^{2}}$, tem-se que a distância $r$ é definida como $r=r^{*}=|J| \varepsilon$, sendo $\varepsilon=\left|\xi-\xi_{0}\right|$ a distância adimensional entre o ponto campo e o ponto fonte.

\subsubsection{Regularização do núcleo $\boldsymbol{u}^{*}$}

O núcleo que contem $u^{*}$ na Equação (2.64) pode ser regularizado por meio da seguinte equação:

$$
\begin{aligned}
\int_{\Gamma} u^{*} q d \Gamma= & \int_{-1}^{1}-\frac{1}{2 \pi} \ln (r) \phi(\xi) J(\xi) d \xi \\
& =\int_{-1}^{1}-\frac{1}{2 \pi} \ln (r) \phi(\xi) J(\xi) d \xi-\int_{-1}^{1}-\frac{1}{2 \pi} \ln \left(r^{*}\right) \phi\left(\xi_{0}\right) J\left(\xi_{0}\right) d \xi \\
& +\int_{-1}^{1}-\frac{1}{2 \pi} \ln \left(r^{*}\right) \phi\left(\xi_{0}\right) J\left(\xi_{0}\right) d \xi
\end{aligned}
$$

As duas primeiras integrais do lado direito da igualdade são limitadas e não são mais singulares, portanto são avaliadas numericamente por meio da quadratura de Gauss-Legendre. Já a última integral é avaliada analiticamente. Define-se por conveniência que essa última integral seja definida por $I$ :

$I=\int_{-1}^{1}-\frac{1}{2 \pi} \ln \left(r^{*}\right) \phi\left(\xi_{0}\right) J\left(\xi_{0}\right) d \xi$

Mudando o domínio de integração de $d \xi$ para $d \varepsilon$ e consequentemente seus intervalos de integração, tem-se:

$I=\int_{-1-\xi_{0}}^{1-\xi_{0}}-\frac{1}{2 \pi} \ln \left(\left|J\left(\xi_{0}\right) \varepsilon\right|\right) \phi\left(\xi_{0}\right) J\left(\xi_{0}\right) d \varepsilon$

Sabendo que $\int \ln (a u) d u=u \ln (|a u|)-u$, sendo $a$ uma constante, analisa-se a integral $I$ no sentido do valor principal de Cauchy conforme:

$$
\begin{aligned}
& V P C=\lim _{\varepsilon \rightarrow 0}\left\{\int_{-1-\xi_{0}}^{-\varepsilon}-\frac{1}{2 \pi} \ln \left(\left|J\left(\xi_{0}\right) \varepsilon\right|\right) \phi\left(\xi_{0}\right) J\left(\xi_{0}\right) d \varepsilon+\int_{\varepsilon}^{1-\xi_{0}}-\frac{1}{2 \pi} \ln \left(\left|J\left(\xi_{0}\right) \varepsilon\right|\right) \phi\left(\xi_{0}\right) J\left(\xi_{0}\right) d \varepsilon\right\} \\
& V P C=\lim _{\varepsilon \rightarrow 0}\left\{-\frac{1}{2 \pi} J\left(\xi_{0}\right) \phi\left(\xi_{0}\right)\left[\int_{-1-\xi_{0}}^{-\varepsilon} \ln \left(\left|J\left(\xi_{0}\right) \varepsilon\right|\right) d \varepsilon+\int_{\varepsilon}^{1-\xi_{0}} \ln \left(\left|J\left(\xi_{0}\right) \varepsilon\right|\right) d \varepsilon\right]\right\} \rightarrow \\
& \left.V P C=\lim _{\varepsilon \rightarrow 0}-\left.\frac{1}{2 \pi} J\left(\xi_{0}\right) \phi\left(\xi_{0}\right)\left\{\left[\varepsilon \ln \left(\mid J\left(\xi_{0}\right) \varepsilon\right) \mid\right)-\varepsilon\right]\right|_{-1-\xi_{0}} ^{-\varepsilon}+\left.\left[\varepsilon \ln \left(\mid J\left(\xi_{0}\right) \varepsilon\right) \mid-\varepsilon\right]\right|_{\varepsilon} ^{1-\xi_{0}}\right\} \rightarrow
\end{aligned}
$$




$$
\begin{gathered}
V P C=\lim _{\varepsilon \rightarrow 0}-\frac{1}{2 \pi} J\left(\xi_{0}\right) \phi\left(\xi_{0}\right)\left\{-\varepsilon \ln \left(\left|J\left(\xi_{0}\right) \varepsilon\right|\right)+\varepsilon-\left[\left(-1-\xi_{0}\right) \ln \left(\left|J\left(\xi_{0}\right)\left(1+\xi_{0}\right)\right|\right)+\left(1+\xi_{0}\right)\right]\right. \\
\left.+\left(1-\xi_{0}\right) \ln \left(\left|J\left(\xi_{0}\right)\left(1-\xi_{0}\right)\right|\right)-\left(1-\xi_{0}\right)-\varepsilon \ln \left(\left|J\left(\xi_{0}\right) \varepsilon\right|\right)+\varepsilon\right\}
\end{gathered}
$$

Pelo teorema de L'Hôpital tem-se que:

$$
\lim _{\varepsilon \rightarrow 0}\left\{\varepsilon \ln \left(J\left(\xi_{0}\right) \varepsilon\right)\right\}=0
$$

Portanto o limite na Equação (2.71) resulta em:

$$
V P C=-\frac{1}{2 \pi} J\left(\xi_{0}\right) \phi\left(\xi_{0}\right)\left\{\left(1+\xi_{0}\right) \ln \left(\left|J\left(\xi_{0}\right)\left(1+\xi_{0}\right)\right|\right)+\left(1-\xi_{0}\right) \ln \left(\left|J\left(\xi_{0}\right)\left(1-\xi_{0}\right)\right|\right)-2\right\}
$$

A equação anterior é válida para os casos onde o ponto fonte não se encontra nos extremos do elemento, ou seja, em $\xi_{0} \neq \pm 1$. Em outras palavras, a equação anterior é válida para elementos descontínuos. Caso sejam utilizados elementos contínuos, deve-se tomar apenas a parte finita da Equação (2.73). Isso é possível pelo fato do termo $\varepsilon \ln (\varepsilon)$ em $\xi=0$ ser nulo. Assim, quando $\xi_{0}= \pm 1$ tem-se:

$V P C=-\frac{1}{2 \pi} J\left(\xi_{0}\right) \phi\left(\xi_{0}\right)\left\{2 \ln \left(\left|2 J\left(\xi_{0}\right)\right|\right)-2\right\}$

\subsubsection{Regularização do núcleo $q^{*}$}

O núcleo que contém $q^{*}$ na Equação (2.64) pode ser regularizado de forma análoga ao que foi feito para o núcleo $u^{*}$. Lembrando que $\frac{\partial r}{\partial \eta}=r_{, k} \eta_{k}=r_{, 1} \eta_{1}+r_{, 2} \eta_{2}$, faz-se:

$$
\begin{aligned}
& \int_{\Gamma} q^{*} u d \Gamma=\int_{-1}^{1}-\frac{1}{2 \pi r} \frac{\partial r}{\partial \eta} \phi(\xi) J(\xi) d \xi=\int_{-1}^{1}-\frac{1}{2 \pi r} r_{k} \eta_{k} \phi(\xi) J(\xi) d \xi \rightarrow \\
& \int_{\Gamma} q^{*} u d \Gamma=\int_{-1}^{1}-\frac{1}{2 \pi r} r_{k} \eta_{k} \phi(\xi) J(\xi) d \xi-\int_{-1}^{1}-\frac{1}{2 \pi r} r_{, k}^{*} \eta_{k} \phi\left(\xi_{0}\right) J\left(\xi_{0}\right) d \xi+\int_{-1}^{1}-\frac{1}{2 \pi r} r_{, k}^{*} \eta_{k} \phi\left(\xi_{0}\right) J\left(\xi_{0}\right) d \xi
\end{aligned}
$$

Deve-se notar que $r_{, k} \eta_{k}$ é nulo no ponto fonte, uma vez que nesse ponto os vetores $r$ e $\eta$ são perpendiculares. Assim, as integrais que dependem de $r_{, k}^{*} \eta_{k}$ são nulas. Quando o elemento a ser integrado possui geometria reta, a primeira integral do lado direito da igualdade também resulta igual a zero. Assim, analisa-se a primeira integral para o caso de elementos curvos, conforme apresentado na Figura 2.11.

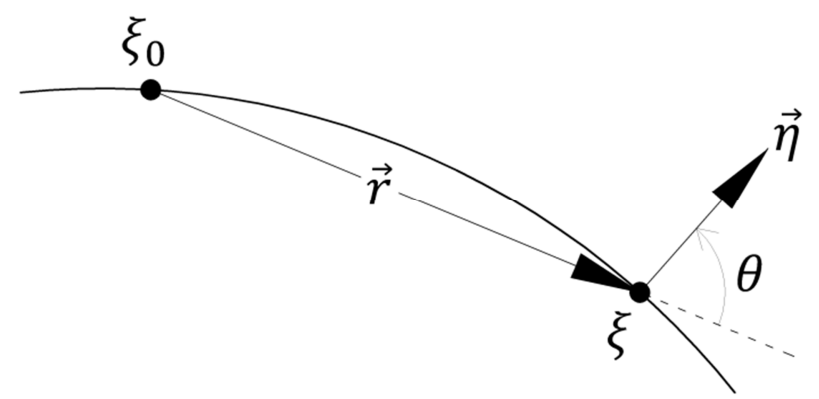

Figura 2.11 - Pontos fonte e campo em elemento curvo 
Lembrando que $\frac{\partial r}{\partial \eta}=\cos \theta=r_{, i} \eta_{i}=\frac{r_{i}}{r} \eta_{i}$, onde:

$r_{1}=x_{1}(\xi)-x_{1}\left(\xi_{0}\right)=x_{1}(\xi)-x_{1}^{0}$

$r_{2}=x_{2}(\xi)-x_{2}\left(\xi_{0}\right)=x_{2}(\xi)-x_{2}^{0}$

$\eta_{1}=\frac{T_{2}(\xi)}{J(\xi)}$

$\eta_{2}=-\frac{T_{1}(\xi)}{J(\xi)}$

$r^{2}=r_{1}^{2}+r_{2}^{2}$

Assim:

$\frac{\partial r}{\partial \eta}=\frac{r_{, 1} \eta_{1}+r_{, 2} \eta_{2}}{r}=\frac{1}{r}\left[r_{1} \frac{T_{2}(\xi)}{J(\xi)}+r_{2} \frac{\left(-T_{1}(\xi)\right)}{J(\xi)}\right]=\frac{r_{1} T_{2}(\xi)-r_{2} T_{1}(\xi)}{r J(\xi)}$

Introduzindo a Equação (2.77) na primeira integral da Equação (2.75) tem-se:

$\int_{-1}^{1}-\frac{1}{2 \pi r}\left[\frac{r_{1} T_{2}(\xi)-r_{2} T_{1}(\xi)}{r J(\xi)}\right] \phi(\xi) J(\xi) d \xi=-\frac{1}{2 \pi} \int_{-1}^{1}\left[\frac{r_{1} T_{2}(\xi)-r_{2} T_{1}(\xi)}{r^{2} J(\xi)}\right] \phi(\xi) J(\xi) d \xi$

Assim, aplicando o teorema de L'Hôpital ao núcleo pode-se avaliar se o mesmo é singular:

$\lim _{\xi \rightarrow \xi_{0}} \frac{r_{1} T_{2}(\xi)-r_{2} T_{1}(\xi)}{r^{2} J(\xi)}=\lim _{\xi \rightarrow \xi_{0}} \frac{r_{1, \xi} T_{2}(\xi)+r_{1} T_{2, \xi}(\xi)-r_{2, \xi} T_{1}(\xi)-r_{2} T_{1, \xi}(\xi)}{2 r r_{, \xi}}$

A derivada de $r$ pode ser relacionada às derivadas das componentes de $r_{1}$ e $r_{2}$ conforme: $r^{2}=r_{1}^{2}(\xi)+r_{2}^{2}(\xi)$

$\left(r^{2}\right)_{, \xi}=2 r_{1} r_{1, \xi}+2 r_{2} r_{2, \xi}=2\left(r_{1} r_{1, \xi}+r_{2} r_{2, \xi}\right)$

Portanto o denominador da Equação (2.79) pode ser reescrito conforme:

$\lim _{\xi \rightarrow \xi_{0}} \frac{r_{1, \xi} T_{2}(\xi)+r_{1} T_{2, \xi}(\xi)-r_{2, \xi} T_{1}(\xi)-r_{2} T_{1, \xi}(\xi)}{2\left(r_{1} r_{1, \xi}+r_{2} r_{2, \xi}\right)}$

Mas sabe-se que:

$r_{1}=x_{1}(\xi)-x_{1}^{0} \rightarrow r_{1, \xi}=\phi_{, \xi}(\xi) x_{1}(\xi)=T_{1}(\xi)$

$r_{2}=x_{2}(\xi)-x_{2}^{0} \rightarrow r_{2, \xi}=\phi_{, \xi}(\xi) x_{2}(\xi)=T_{2}(\xi)$

Portanto, a Equação (2.81) é reescrita conforme:

$\lim _{\xi \rightarrow \xi_{0}} \frac{T_{1}(\xi) T_{2}(\xi)+T_{2}(\xi) T_{1}(\xi)}{2\left(r_{1} r_{1, \xi}+r_{2} r_{2, \xi}\right)}+\lim _{\xi \rightarrow \xi_{0}} \frac{r_{1} T_{2, \xi}(\xi)-r_{2} T_{1, \xi}(\xi)}{2\left(r_{1} r_{1, \xi}+r_{2} r_{2, \xi}\right)}$

O limite da esquerda resulta igual a zero pois os vetores tangentes são perpendiculares entre si. Utilizando as definições da Equação (2.82), o limite da direita é escrito como: 
$\lim _{\xi \rightarrow \xi_{0}} \frac{r_{1} T_{2, \xi}(\xi)-r_{2} T_{1, \xi}(\xi)}{2\left(r_{1} T_{1}(\xi)+r_{2} T_{2}(\xi)\right)}$

Pode-se substituir $r_{, 1}=\frac{r_{1}}{r}$ e $r_{, 2}=\frac{r_{2}}{r}$ na Equação (2.84), o que resulta em:

$$
\lim _{\xi \rightarrow \xi_{0}} \frac{r_{, 1} r T_{2, \xi}(\xi)-r_{, 2} r T_{1, \xi}(\xi)}{2\left(r_{, 1} r T_{1}(\xi)+r_{, 2} r T_{2}(\xi)\right)}=\lim _{\xi \rightarrow \xi_{0}} \frac{r_{, 1} T_{2, \xi}(\xi)-r_{, 2} T_{1, \xi}(\xi)}{2\left(r_{, 1} T_{1}(\xi)+r_{, 2} T_{2}(\xi)\right)}
$$

A relação entre o vetor tangente e sua derivada é a seguinte:

$$
\begin{gathered}
T_{1, \xi}(\xi)=-T_{2}(\xi) \\
T_{2, \xi}(\xi)=T_{1}(\xi)
\end{gathered}
$$

Assim, a Equação (2.85) é escrita conforme:

$$
\lim _{\xi \rightarrow \xi_{0}} \frac{r_{, 1} T_{1}(\xi)+r_{, 2} T_{2}(\xi)}{2\left(r_{, 1} T_{1}(\xi)+r_{, 2} T_{2}(\xi)\right)}=\lim _{\xi \rightarrow \xi_{0}} \frac{1}{2}
$$

Portanto o núcleo integral existe e é finito desde que não exista um ponto de curvatura não suave (bico) onde os vetores tangente e normal não sejam únicos. Conclui-se que o núcleo contendo $q^{*}$ é não singular e possuirá valor igual a zero ou outro valor finito.

\subsubsection{Determinação das grandezas internas}

Uma vez conhecidas as grandezas no contorno, é possível calcular o valor das grandezas no domínio. O valor do potencial num dado ponto do domínio é calculado, a partir da Equação (2.63), conforme:

$u(\varsigma)=\int_{\Gamma} u^{*}(\varsigma, x) q(x) d \Gamma-\int_{\Gamma} q^{*}(\varsigma, x) u(x) d \Gamma$

sendo que $c(\zeta)=1$, pois o ponto em questão está internamente ao contorno. Já para a determinação do fluxo nos pontos internos deve-se derivar a Equação (2.63), lembrando que $\frac{\partial u}{\partial x_{i}}=q_{i}=u_{, i}$

$$
\begin{aligned}
& \frac{\partial}{\partial x_{i}(\varsigma)} u(\varsigma)+\int_{\Gamma} \frac{\partial}{\partial x_{i}(\varsigma)}\left(q^{*}(\varsigma, x) u(x)\right) d \Gamma=\int_{\Gamma} \frac{\partial}{\partial x_{i}(\varsigma)}\left(u^{*}(\varsigma, x) q(x)\right) d \Gamma \rightarrow \\
& q_{i}(\varsigma)+\int_{\Gamma} \frac{\partial q^{*}(\varsigma, x)}{\partial x_{i}(\varsigma)} u(x) d \Gamma=\int_{\Gamma} \frac{\partial u^{*}(\varsigma, x)}{\partial x_{i}(\varsigma)} q(x) d \Gamma
\end{aligned}
$$

Assim a equação integral fica definida em termos das derivadas das soluções fundamentais em função do ponto fonte. Lembrando que $\frac{\partial f(\varsigma, x)}{\partial x(\varsigma)}=-\frac{\partial f(\varsigma, x)}{\partial x(x)}$ e que as soluções fundamentais são $u^{*}=-\frac{1}{2 \pi} \ln (r)$ e $q^{*}=-\frac{1}{2 \pi r} r_{k \eta_{k}}$, tem-se para o núcleo $u^{*}$ : 
$\frac{\partial u^{*}(\varsigma, x)}{\partial x_{i}(\varsigma)}=-\frac{\partial u^{*}(\varsigma, x)}{\partial x_{i}(x)}=-\frac{\partial}{\partial x_{i}(x)}\left(-\frac{1}{2 \pi} \ln (r)\right)=d_{i}^{*}(\varsigma, x)=\frac{1}{2 \pi r} r_{, i}$

Lembrando que $r_{, k}=\frac{r_{k}}{r}$, tem-se para o núcleo $q^{*}$ :

$\frac{\partial q^{*}(\varsigma, x)}{\partial x_{i}(\varsigma)}=-\frac{\partial q^{*}(\varsigma, x)}{\partial x_{i}(x)}=-\frac{\partial}{\partial x_{i}(x)}\left(-\frac{1}{2 \pi r} r_{, k} \eta_{k}\right)=\frac{1}{2 \pi} \frac{\partial}{\partial x_{i}(x)}\left(\frac{r_{, k} \eta_{k}}{r}\right) \rightarrow$

$\frac{\partial q^{*}(\varsigma, x)}{\partial x_{i}(\varsigma)}=\frac{1}{2 \pi} \frac{\partial}{\partial x_{i}(x)}\left(\frac{r_{k} \eta_{k}}{r^{2}}\right)=\frac{1}{2 \pi}\left(\frac{r_{k, i} \eta_{k}}{r^{2}}+\frac{-2 r_{k} \eta_{k}}{r^{3}} r_{, i}\right)$

Destaca-se que $r_{k, i}=\Delta_{k i}$, uma vez que só existe derivada não nula quando $k=i$, sendo esta unitária. Algumas propriedades do delta de Kronecker $\Delta_{k i}$ podem ser consultadas no Anexo B da presente tese. Assim:

$\frac{\partial q^{*}(\varsigma, x)}{\partial x_{i}(\varsigma)}=\frac{1}{2 \pi}\left(\frac{\Delta_{k i} \eta_{k}}{r^{2}}-\frac{2 \frac{r_{k}}{r} \eta_{k} r_{, i}}{r^{2}}\right)=\frac{1}{2 \pi}\left(\frac{\Delta_{k i} \eta_{k}}{r^{2}}-\frac{2 r_{, k} \eta_{k} r_{, i}}{r^{2}}\right)$

Simplificando o termo que contém $\Delta_{k i}$, tem-se:

$\frac{\partial q^{*}(\varsigma, x)}{\partial x_{i}(\varsigma)}=\frac{1}{2 \pi}\left(\frac{\eta_{i}}{r^{2}}-\frac{2 r_{, k} \eta_{k} r_{, i}}{r^{2}}\right)=s_{i}^{*}(\varsigma, x)=\frac{\eta_{i}-2 \frac{\partial r}{\partial \eta} r_{, i}}{2 \pi r^{2}}$

Assim, os fluxos nos pontos internos podem ser calculados conforme:

$q_{i}(\varsigma)=\int_{\Gamma} d_{i}^{*}(\varsigma, x) q(x) d \Gamma-\int_{\Gamma} s_{i}^{*}(\varsigma, x) u(x) d \Gamma$

Sendo que $d_{i}^{*}(\zeta, x)$ e $s_{i}^{*}(\zeta, x)$ são dados pelas Equações (2.90) e (2.93) respectivamente.

\subsubsection{Implementação computacional}

A equação integral de contorno que descreve o problema potencial com termo de domínio nulo, escrita de forma discretizada, é dada pela Equação (2.65), repetida aqui por conveniência:

$c_{i}(\varsigma) u_{i}(\varsigma)+\sum_{j=1}^{N E} \sum_{l=1}^{N G} q_{i}^{j^{*}}(\xi) u_{i}(\xi) \phi_{j}(\xi) J(\xi) w_{l}=\sum_{j=1}^{N E} \sum_{l=1}^{N G} u_{i}^{j^{*}}(\xi) q_{i}(\xi) \phi_{j}(\xi) J(\xi) w_{l}$

Como condições de contorno, em cada um dos nós $i$ do contorno, deve-se saber de antemão o valor do fluxo $\left(q_{i}\right)$ ou do potencial $\left(u_{i}\right)$, de forma que seja possível montar um sistema de equações que possua um número de incógnitas igual ao número de equações. Além disso, os nós dos elementos estão posicionados no contorno (que é suave pelo fato dos elementos possuírem nós descontínuos), de forma que $c_{i}(\varsigma)=\frac{1}{2}=0,5$. Reescrevendo a Equação (2.95) de forma compacta: 
$0,5 u_{i}(\varsigma)+\sum_{j=1}^{N E} \widehat{H}_{i j} u_{i}=\sum_{j=1}^{N E} G_{i j} q_{i}$

em que:

$$
\begin{aligned}
\widehat{H}_{i j} & =\sum_{l=1}^{N G} q_{i}^{j^{*}}(\xi) \phi_{j}(\xi) J(\xi) w_{l} \\
G_{i j} & =\sum_{l=1}^{N G} u_{i}^{j^{*}}(\xi) \phi_{j}(\xi) J(\xi) w_{l} \\
H_{i j} & =\left\{\begin{array}{cc}
\widehat{H}_{i j}+0,5 & \text { se } i=j \\
\widehat{H}_{i j} & \text { se } i \neq j
\end{array}\right.
\end{aligned}
$$

A Equação (2.96) é utilizada em cada um dos nós dos elementos que discretizam o contorno, sendo que cada nó é interpretado como um ponto fonte. $\mathrm{Na}$ Equação (2.98) destaca-se que na diagonal da matriz $H_{i j}$ deve-se somar o valor $\frac{1}{2}$, proveniente do termo livre quando o ponto fonte está posicionado sobre um contorno suave. Além disso, quando o nó fonte estiver integrando o elemento ao qual ele pertence, utiliza-se o método de subtração de singularidade, conforme descrito pelas Equações (2.68) e (2.73). A Equação (2.96) é então escrita para cada um dos nós, resultando em um sistema de equações que possui o seguinte formato:

$$
[H]\{u\}=[G\}\{q\}
$$

As matrizes $[H]$ e $[G]$ contém os núcleos integrais dependentes das soluções fundamentais $q^{*}$ e $u^{*}$, respectivamente. Os vetores $\{u\}$ e $\{q\}$ contém os valores de potencial e de fluxo nos nós do contorno, respectivamente. Destaca-se que as condições de contorno do problema, ou seja, o conhecimento prévio dos valores do potencial e do fluxo em determinados pontos do contorno são utilizados já na montagem dos vetores $\{u\}$ e $\{q\}$. Após a aplicação dessas condições de contorno e da montagem das matrizes $[H]$ e $[G]$, realiza-se um processo de troca de colunas entre essas matrizes e de troca de posições entre os vetores $\{u\}$ e $\{q\}$, de forma que o sistema resultante seja igual a:

$$
[A]\{x\}=[B\}\{z\}
$$

Sendo $[A]$ a matriz que contém os termos $H_{i j}$ ou $-G_{i j}$ que multiplicam as componentes do vetor $\{x\}$ que contém as grandezas incógnitas no contorno (fluxo ou potencial) e sendo $[B]$ a matriz que contém os termos $G_{i j}$ ou $-H_{i j}$ que multiplicam as componentes do vetor $\{z\}$ que contém as grandezas conhecidas no contorno (fluxo ou potencial). Como a matriz $[B]$ e o vetor 
$\{z\}$ possuem valores numéricos conhecidos, pode-se proceder sua multiplicação, o que resulta em:

$[A]\{x\}=\{f\}$

Sendo $\{f\}$ chamado de vetor de termos independentes. O vetor de grandezas incógnitas pode então ser determinado da seguinte maneira:

$\{x\}=[A]^{-1}\{f\}$

Após o cálculo do vetor $\{x\}$ é possível calcular o valor numérico das grandezas internas. Para o cálculo do potencial em pontos internos, utiliza-se a Equação (2.88), repetida aqui por conveniência:

$u(\varsigma)=\int_{\Gamma} u^{*}(\varsigma, x) q(x) d \Gamma-\int_{\Gamma} q^{*}(\varsigma, x) u(x) d \Gamma$

As integrais acima são avaliadas numericamente de forma análoga ao que é feito na Equação (2.95):

$u_{i}(\varsigma)=\sum_{j=1}^{N E} \sum_{l=1}^{N G} u_{i}^{j^{*}}(\xi) q_{i}(\xi) \phi_{j}(\xi) J(\xi) w_{l}-\sum_{j=1}^{N E} \sum_{l=1}^{N G} q_{i}^{j^{*}}(\xi) u_{i}(\xi) \phi_{j}(\xi) J(\xi) w_{l}$

Reescrevendo a equação acima de forma compacta:

$u_{i}(\varsigma)=\sum_{j=1}^{N E} G_{i j}^{\prime} q_{i}-\sum_{j=1}^{N E} H_{i j}^{\prime} u_{i}$

Utilizando a equação acima para cada um dos nós internos tem-se:

$\left\{u_{\text {int }}\right\}=\left[G^{\prime}\right]\{q\}-\left[H^{\prime}\right]\{u\}$

sendo $\left\{u_{\text {int }}\right\}$ o vetor que contém os potenciais nos pontos internos, $\{q\}$ e $\{u\}$ os vetores que contêm os fluxos e potenciais nos nós do contorno, totalmente conhecidos após a solução dada pela Equação (2.102). As matrizes $\left[G^{\prime}\right]$ e $\left[H^{\prime}\right]$ contém os núcleos integrais dependentes das soluções fundamentais $q^{*}$ e $u^{*}$, respectivamente, calculadas agora considerando os pontos internos como sendo os pontos fonte e considerando os pontos do contorno como sendo os pontos campo.

O fluxo em pontos internos pode ser calculado utilizando-se da Equação (2.94), repetida aqui por conveniência:

$q_{i}(\varsigma)=\int_{\Gamma} d_{i}^{*}(\varsigma, x) q(x) d \Gamma-\int_{\Gamma} s_{i}^{*}(\varsigma, x) u(x) d \Gamma$

A equação acima é avaliada numericamente de forma análoga ao que é feito para o cálculo do potencial em pontos internos, resultando em: 
$\left\{q_{\text {int }}\right\}=[D]\{q\}-[S]\{u\}$

sendo $\left\{q_{\text {int }}\right\}$ o vetor que contém os fluxos nos nós internos e $[D]$ e $[S]$ as matrizes que contém os núcleos integrais dependentes das derivadas das soluções fundamentais em função do ponto fonte. Destaca-se que tanto no cálculo do potencial quanto no do fluxo em pontos internos não é necessário utilizar o método de subtração de singularidade, uma vez que os núcleos nas Equações (2.103) e (2.107) não são singulares.

Um fluxograma da implementação computacional do MEC para problemas de potencial em regime estacionário é ilustrado na Figura 2.12.

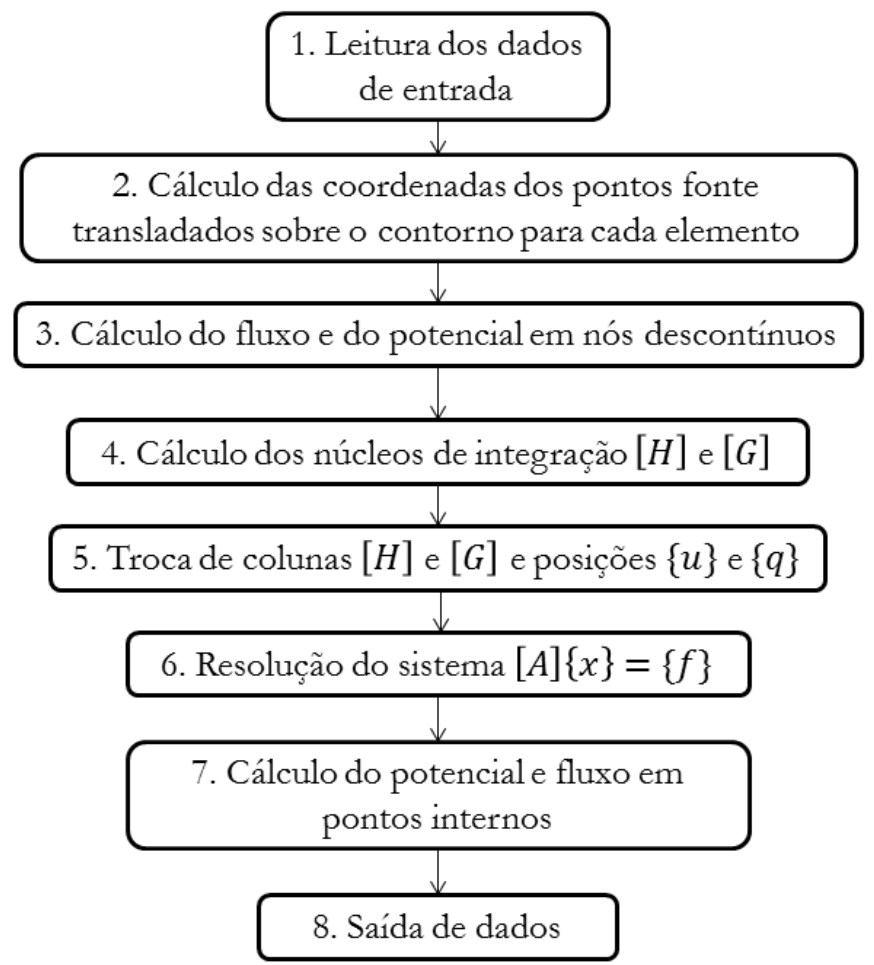

Figura 2.12 - Fluxograma do programa via MEC para problemas de difusão estacionário

No passo 3 da Figura 2.12 vale comentar que, pelo fato dos nós de interseção entre elementos serem descontinuados e, portanto, transladados para o interior dos elementos, é necessário realizar uma correção nos valores de potencial e fluxo nesses nós. Tal correção é feita por meio da interpolação dos valores das grandezas do contorno dos demais nós pertencentes ao elemento.

\subsection{Regime de difusão transiente}

A equação de Laplace e a equação de Poisson apresentadas na seção 2.2.1 são independentes do tempo $t$. Portanto, a solução de tais equações conduz a uma resposta em um regime estacionário. Contudo, a compreensão e análise de difusão em regime transiente, ou seja, 
dependente do tempo, é necessária, uma vez que em estruturas de concreto esse fenômeno ocorre ao longo de muitos anos. Destaca-se que, em uma análise de regime transiente, a resposta do sistema tenderá a ser igual àquela em regime permanente, conforme o avanço do tempo. Além disso, destaca-se que boa parte da metodologia da formulação do problema estacionário é utilizada também no problema em regime transiente.

\subsubsection{Equações integrais}

A equação diferencial para problemas de potencial em regime transiente, também chamada de equação diferencial da difusão é:

$$
\nabla^{2} u(x, t)-\frac{1}{\kappa} \frac{\partial u(x, t)}{\partial t}=0
$$

As condições de contorno do problema são:

- Essenciais: $u(x, t)=\bar{u}(x, t)$ em $\Gamma_{1}$;

- Naturais: $q(x, t)=\bar{q}(x, t)=\frac{\partial u(x, t)}{\partial \eta(x)}$ em $\Gamma_{2}$.

Sendo $\bar{u}(x, t)$ e $\bar{q}(x, t)$ os valores prescritos do potencial e do fluxo, respectivamente, em um ponto $x$ em um instante $t$. Esses valores devem ser prescritos inclusive no tempo $t_{0}$, no qual a análise do fenômeno inicia-se. $\mathrm{O}$ coeficiente $\kappa$ assume diversos nomes segundo o problema físico modelado pela Equação (2.109). Neste trabalho, $\kappa$ recebe o nome de coeficiente de difusão de cloretos ou simplesmente coeficiente de difusão, sendo que essa grandeza possui dimensão igual a $\left[L^{2} T^{-1}\right]$, como por exemplo $\mathrm{mm}^{2} /$ ano. Como o problema é dependente do tempo, condições iniciais de domínio no tempo $t=t_{0}$ devem ser prescritas:

$u(x, t)=u_{0}\left(x, t_{0}\right)=u_{0}$ em $\Omega$

A transformada de Laplace para uma função $u(x, t)$ é dada por:

$L[u(x, t)]=U(x, \lambda)=\int_{0}^{\infty} u(x, t) e^{-\lambda t} d t$

sendo o parâmetro de transformação $\lambda$ real e positivo. Integrando por partes mostra-se que:

$L\left[\frac{\partial u(x, t)}{\partial t}\right]=\lambda U(x, \lambda)-u_{0}\left(x, t_{0}\right)$

A Equação (2.109) no espaço transformado torna-se:

$\nabla^{2} U(x, \lambda)-\frac{\lambda}{\kappa} U(x, \lambda)+\frac{1}{\kappa} u_{0}\left(x, t_{0}\right)=0$

As condições de contorno da Equação (2.110) são assumidas por simplicidade como sendo constantes no tempo, sendo transformadas conforme: 


$$
\begin{array}{ll}
U(x, \lambda)=\bar{U}(x, \lambda)=\frac{\bar{u}(x, \lambda)}{\lambda} & \text { em } \Gamma_{1} \\
Q(x, \lambda)=\bar{Q}(x, \lambda)=\frac{\bar{q}(x, \lambda)}{\lambda} & \text { em } \Gamma_{2} .
\end{array}
$$

Integrando a Equação (2.114) em todo o domínio e aplicando ponderação para avaliar resíduos obtém-se:

$$
\begin{gathered}
\int_{\Omega}\left[\nabla^{2} U(x, \lambda)-\frac{\lambda}{\kappa} U(x, \lambda)+\frac{1}{\kappa} u_{0}\left(x, t_{0}\right)\right] U^{*}(\varsigma, x, \lambda) d \Omega=\int_{\Gamma_{2}}[Q(x, \lambda)-\bar{Q}(x, \lambda)] U^{*}(\varsigma, x, \lambda) d \Gamma \\
-\int_{\Gamma_{1}}[U(x, \lambda)-\bar{U}(x, \lambda)] Q^{*}(\varsigma, x, \lambda) d \Gamma
\end{gathered}
$$

sendo $Q^{*}(\varsigma, x, \lambda)=\frac{\partial U^{*}(\varsigma, x, \lambda)}{\partial \eta}$. Integrando por partes duas vezes o Laplaciano na equação acima tem-se:

$$
\begin{aligned}
\int_{\Omega}\left[\nabla^{2} U^{*}(x, \lambda)\right. & \left.-\frac{\lambda}{\kappa} U^{*}(x, \lambda)\right] U^{*}(x, \lambda) d \Omega+\frac{1}{\kappa} \int_{\Omega} u_{0}\left(x, t_{0}\right) U^{*}(\varsigma, x, \lambda) d \Omega \\
= & -\int_{\Gamma} Q(x, \lambda) U^{*}(\varsigma, x, \lambda) d \Gamma+\int_{\Gamma} U(x, \lambda) Q^{*}(\varsigma, x, \lambda) d \Gamma
\end{aligned}
$$

Assumindo que $U^{*}$ seja a solução fundamental da Equação (2.114) a equação acima é reescrita conforme:

$$
\begin{aligned}
U(\varsigma, \lambda)+\kappa \int_{\Gamma} & U(x, \lambda) Q^{*}(\varsigma, x, \lambda) d \Gamma \\
= & \kappa \int_{\Gamma} Q(x, \lambda) U^{*}(\varsigma, x, \lambda) d \Gamma+\int_{\Omega} u_{0}\left(x, t_{0}\right) U^{*}(\varsigma, x, \lambda) d \Omega
\end{aligned}
$$

A solução fundamental $U^{*}$ para casos tridimensionais é igual a:

$$
U^{*}=\frac{(\kappa \lambda)^{1 / 4}}{r^{1 / 2}(2 \pi \kappa)^{3 / 2}} K_{1 / 2}\left[\left(\frac{\lambda}{\kappa}\right)^{1 / 2} r\right]
$$

Para problemas bidimensionais tem-se:

$$
U^{*}=\frac{1}{2 \pi \kappa} K_{0}\left[\left(\frac{\lambda}{\kappa}\right)^{1 / 2} r\right]
$$

sendo $K_{v}$ a função de Bessel modificada de segundo tipo de ordem $v$. A singularidade da Equação (2.119) é avaliada quando $r \rightarrow 0$. A função de Bessel modificada $K_{1 / 2}(z) \operatorname{com} z \rightarrow 0$ resulta em:

$$
K_{1 / 2}(z)=\left(\frac{\pi}{2 z}\right)^{1 / 2}
$$

Assim, quando $r \rightarrow 0$, a Equação (2.119) resulta: 
$U^{*}=\frac{(\kappa \lambda)^{1 / 4}}{r^{1 / 2}(2 \pi \kappa)^{3 / 2}}\left(\frac{\pi}{2 r}\right)^{1 / 2}\left[\left(\frac{\kappa}{\lambda}\right)^{1 / 4}\right]=\frac{1}{4 \pi \kappa r}$

Observando a Equação (2.122) conclui-se que a singularidade da solução fundamental $U^{*}$ para o caso tridimensional é do mesmo tipo que aquela descrita anteriormente para a equação de Poisson/Laplace. De forma análoga, a função de Bessel modificada $K_{0}(z) \operatorname{com} z \rightarrow 0$ resulta:

$K_{0}(z)=-\ln (z)$

Assim, quando $r \rightarrow 0$, a Equação (2.120) resulta:

$U^{*}=\frac{1}{2 \pi \kappa} \ln \left(\frac{1}{r}\right)-\frac{1}{4 \pi \kappa} \ln \left(\frac{\lambda}{\kappa}\right)$

O primeiro termo do lado direito da igualdade é a solução fundamental para a equação de Poisson/Laplace. Já o segundo termo é uma constante não singular.

Além da transformada de Laplace para transformar a equação diferencial parcial em uma equação integral de contorno, pode-se utilizar uma abordagem via diferenças finitas para a aproximação temporal. Contudo, neste trabalho, utiliza-se ainda outra abordagem, que faz uso de soluções fundamentais dependentes do tempo, sendo explorada a seguir.

Considerando a dependência do tempo para o problema diretamente no processo de integração por partes, é possível escrever a seguinte equação utilizando-se resíduos ponderados para a equação de difusão com suas condições de contorno:

$$
\begin{aligned}
\int_{t_{0}}^{t_{F}} \int_{\Omega}\left[\nabla^{2} u(x, t)-\frac{1}{\kappa} \frac{\partial u(x, t)}{\partial t}\right] u^{*}\left(s, x, t_{F}, t\right) d \Omega d t \\
=\int_{t_{0}}^{t_{F}} \int_{\Gamma_{2}}[q(x, t)-\bar{q}(x, t)] u^{*}\left(s, x, t_{F}, t\right) d \Gamma d t \\
-\int_{t_{0}}^{t_{F}} \int_{\Gamma_{1}}[u(x, t)-\bar{u}(x, t)] q^{*}\left(s, x, t_{F}, t\right) d \Gamma d t
\end{aligned}
$$

sendo $q^{*}\left(\varsigma, x, t_{F}, t\right)=\frac{\partial u^{*}\left(\varsigma, x, t_{F}, t\right)}{\partial \eta}$. Integrando por partes duas vezes o Laplaciano e uma vez a derivada temporal tem-se:

$$
\begin{gathered}
\int_{t_{0}}^{t_{F}} \int_{\Omega}\left[\nabla^{2} u^{*}\left(\varsigma, x, t_{F}, t\right)+\frac{1}{\kappa} \frac{\partial u^{*}\left(\varsigma, x, t_{F}, t\right)}{\partial t}\right] u(x, t) d \Omega d t-\frac{1}{\kappa}\left[\int_{\Omega} u(x, t) u^{*}\left(\varsigma, x, t_{F}, t\right) d \Omega\right]_{t=t_{0}}^{t=t_{F}} \\
=-\int_{t_{0}}^{t_{F}} \int_{\Gamma} q(x, t) u^{*}\left(\varsigma, x, t_{F}, t\right) d \Gamma d t+\int_{t_{0}}^{t_{F}} \int_{\Gamma} u(x, t) q^{*}\left(\varsigma, x, t_{F}, t\right) d \Gamma d t
\end{gathered}
$$

A solução fundamental dependente do tempo $u^{*}$ é:

$$
u^{*}=\frac{1}{(4 \pi \kappa \tau)^{d / 2}} \exp \left[-\frac{r^{2}}{4 \kappa \tau}\right] H(\tau)
$$


sendo $t_{F}$ o tempo de avaliação/observação, $t$ o tempo de aplicação da fonte, $\tau=t_{F}-t, d$ a dimensão do problema $(d=3$ para problemas tridimensionais e $d=2$ para problemas bidimensionais) e $H($.$) a função Heaviside. A função Heaviside consta na equação (2.127) apenas$ para indicar que a solução é igual a zero se o tempo de aplicação da fonte acorrer após o tempo de avaliação/observação, ou seja, quando $t>t_{F}$.

A solução fundamental possui as seguintes propriedades:

$\kappa \nabla^{2} u^{*}\left(\varsigma, x, t_{F}, t\right)+\frac{\partial u^{*}\left(s, x, t_{F}, t\right)}{\partial t}=-\delta(\varsigma, x) \delta\left(t_{F}, t\right)$

$\lim _{t \rightarrow t_{F}} u^{*}\left(\varsigma, x, t_{F}, t\right)=\delta(\varsigma, x)$

sendo $\delta($.$) a função delta de Dirac. A fim de investigar a singularidade presente na Equação$ (2.126) no tempo $t=t_{F}$, pode-se subtrair (ou adicionar) ao limite superior das integrais uma pequena quantidade arbitrária $\varepsilon$. Assim, a primeira integral do lado esquerdo da igualdade é igual a zero para $t$ variando de 0 a $t_{F}-\varepsilon$, tomando o limite quando $\varepsilon \rightarrow 0$ e considerando a Equação (2.129) tem-se:

$$
\begin{aligned}
u(\varsigma, x)+\int_{t_{0}}^{t_{F}} & \int_{\Gamma} \kappa u(x, t) q^{*}\left(s, x, t_{F}, t\right) d \Gamma d t \\
& =\int_{t_{0}}^{t_{F}} \int_{\Gamma} \kappa q(x, t) u^{*}\left(\varsigma, x, t_{F}, t\right) d \Gamma d t+\int_{\Omega} u_{0}\left(x, t_{0}\right) u^{*}\left(\varsigma, x, t_{F}, t\right) d \Omega
\end{aligned}
$$

Outra propriedade da solução fundamental dependente do tempo diz respeito à quando se alcança um regime estacionário, sendo que esta torna-se a solução fundamental para a equação de Poisson/Laplace, isto é:

$$
\lim _{t_{F} \rightarrow \infty} \int_{0}^{t_{F}} u^{*}\left(\varsigma, x, t_{F}, t\right) d t=u^{*}(\varsigma, x)
$$

Essa propriedade é válida tanto em casos 2D quanto em casos 3D. É possível mostrar essa propriedade integrando-se a Equação (2.127) de 0 a $t_{F}$ analiticamente introduzindo a variável $x=r^{2} / 4 \kappa \tau$, o que resultam em, para $d=3$ :

$$
\int_{0}^{t_{F}} u^{*} d t=\int_{0}^{t_{F}} \frac{1}{(4 \pi \kappa \tau)^{3 / 2}} \exp \left[-\frac{r^{2}}{4 \kappa \tau}\right] d t=\frac{1}{4 \pi^{3 / 2} \kappa r} \int_{a}^{\infty} x^{-1 / 2} e^{-x} d x=\frac{1}{4 \pi^{3 / 2} \kappa r} \Gamma\left(\frac{1}{2}, a\right)
$$

sendo $a=r^{2} / 4 \kappa t_{F}$ e $\Gamma$ a função gama incompleta. Avaliando o limite da Equação (2.132) quando $t_{F} \rightarrow \infty$ tem-se:

$$
\lim _{t_{F} \rightarrow \infty}\left[\int_{0}^{t_{F}} u^{*} d t\right]=\frac{1}{4 \pi^{3 / 2} \kappa r} \lim _{t_{F} \rightarrow \infty} \Gamma\left(\frac{1}{2}, a\right)=\frac{1}{4 \pi \kappa r}
$$


A Equação (2.133) é a solução fundamental da equação $\kappa \nabla^{2} u=0$. Conclusões semelhantes são obtidas para o caso de $d=0$.

Nota-se que as primeiras duas integrais na Equação (2.130) representam os efeitos das condições de contorno, enquanto que a terceira integral inclui os efeitos do valor inicial $u_{0}$ da função $u$. Conforme $t_{F}$ tende a infinito, as condições iniciais desaparecem, enquanto que as integrações em $t$ para os termos de contorno podem ser feitas assumindo que $u$ e $q$ não mais dependem de $t$. Assim, em virtude da Equação (2.131), a solução fundamental se reduz à equação de Laplace e a Equação (2.130) se torna a equação integral para problemas de potencial estacionários (Equação (2.63)). Levando o ponto $\varsigma$ na Equação (2.130) para o contorno tem-se:

$$
\begin{aligned}
c(s) u(s, x)+ & \int_{t_{0}}^{t_{F}} \int_{\Gamma} \kappa u(x, t) q^{*}\left(s, x, t_{F}, t\right) d \Gamma d t \\
& =\int_{t_{0}}^{t_{F}} \int_{\Gamma} \kappa q(x, t) u^{*}\left(\varsigma, x, t_{F}, t\right) d \Gamma d t+\int_{\Omega} u_{0}\left(x, t_{0}\right) u^{*}\left(s, x, t_{F}, t\right) d \Omega
\end{aligned}
$$

sendo $c(\zeta)$ o termo livre, conforme já especificado na formulação do problema em regime estacionário. Uma vez que a variação temporal das funções $u$ e $q$ não são conhecidas a priori, uma técnica de avanço no tempo deve ser introduzida para a solução numérica da Equação (2.134). Nesse sentido, duas diferentes estratégias podem ser adotadas. A primeira trata cada passo de tempo como um novo problema e assim, ao final de cada passo, calcula-se o valor da função $u$ em um número suficiente de pontos internos a fim de usá-los como valores pseudoiniciais para o próximo passo. $\mathrm{Na}$ segunda estratégia, a qual é adotada na presente tese, o processo de integração temporal sempre recomeça a partir do tempo $t_{0}$ e assim, apesar do crescente número de passos intermediários com o avanço do tempo, valores de potencial $u$ em nós internos não precisam ser recalculados. Além disso, se $u_{0}$ satisfaz a equação de Laplace, a integral de domínio da Equação (2.134) pode ser transformada em uma integral de contorno equivalente.

\subsubsection{Discretização da equação integral}

Para a solução numérica da Equação (2.134), o contorno $\Gamma$ é discretizado em uma série de elementos. A geometria desses elementos pode ser representada por retas, parábolas, etc., conforme já explicado na seção 2.2.4. Além disso, assume-se que as funções $u$ e $q$ possam variar a cada elemento e em cada passo de tempo de acordo com as funções de interpolação no espaço $\phi$ e no tempo $\psi$. Assim, tem-se:

$$
u(\xi)=\phi \psi u
$$


$q(\xi)=\phi \psi q$

Conforme já comentado na Equação (2.127), a solução fundamental $u^{*}$ e sua derivada em função do vetor normal ao contorno são, para o caso bidimensional:

$$
\begin{aligned}
& u^{*}=\frac{1}{4 \pi \kappa \tau} \exp \left[-\frac{r^{2}}{4 \kappa \tau}\right] \\
& q^{*}=\frac{r \frac{\partial r}{\partial \eta}}{8 \pi \kappa^{2} \tau^{2}} \exp \left[-\frac{r^{2}}{4 \kappa \tau}\right]
\end{aligned}
$$

Discretizando-se o contorno $\Gamma$ em $N E$ elementos, o domínio $\Omega$ em $N C$ células, o tempo $t_{F}-t_{0}$ em $N T$ passos e introduzindo-se a Equação (2.135) na Equação (2.134) tem-se:

$$
\begin{aligned}
c_{i}(\varsigma) u_{i}^{N T}\left(\varsigma, t_{F}\right)+ & \sum_{j=1}^{N E} \sum_{k=1}^{N T}\left[\int_{\Gamma_{j}} \phi_{j}(\xi) \int_{t_{0}^{k}}^{t_{f}^{k}} \kappa q^{*}\left(\varsigma, x, t_{F}, t\right) \psi d t d \Gamma_{j}\right] u_{j}^{k} \\
& =\sum_{j=1}^{N E} \sum_{k=1}^{N T}\left[\int_{\Gamma_{j}} \phi_{j}(\xi) \int_{t_{0}^{k}}^{t_{f}^{k}} \kappa u^{*}\left(\varsigma, x, t_{F}, t\right) \psi d t d \Gamma_{j}\right] q_{j}^{k}+\sum_{m=1}^{N C} \int_{\Omega_{m}} u^{*}\left(\varsigma, x, t_{F}, t\right) u_{0} d \Omega
\end{aligned}
$$

De forma similar ao que foi feito na formulação apresentada para o regime estacionário, onde o termo de domínio foi arbitrado igual a zero, aqui arbitra-se que a condição inicial seja nula, ou seja, $u_{0}=0$. Mesmo no caso em que $u_{0}$ seja diferente de zero, a integral de domínio na Equação (2.137) pode ser transformada em uma integral de contorno desde que $u_{0}$ seja uma função harmônica, isto é, uma função diferente de zero que seja solução para a equação de Laplace, cujas derivadas primeira e segunda são contínuas.

Além do que foi acima considerado, assume-se que as funções $u$ e $q$ permaneçam constantes no tempo a cada passo de tempo (podendo ainda variar no espaço), isto é, a função $\psi$ é igual a unidade. A partir dessas considerações a Equação (2.137) é reescrita conforme:

$$
\begin{aligned}
c_{i}(\varsigma) u_{i}^{N T}\left(s, t_{F}\right) & +\sum_{j=1}^{N E} \sum_{k=1}^{N T}\left[\int_{\Gamma_{j}} \phi_{j}(\xi) \int_{t_{0}^{k}}^{t_{f}^{k}} \kappa q^{*}\left(\varsigma, x, t_{F}, t\right) d t d \Gamma_{j}\right] u_{j}^{k} \\
& =\sum_{j=1}^{N E} \sum_{k=1}^{N T}\left[\int_{\Gamma_{j}} \phi_{j}(\xi) \int_{t_{0}^{k}}^{t_{f}^{k}} \kappa u^{*}\left(\varsigma, x, t_{F}, t\right) d t d \Gamma_{j}\right] q_{j}^{k}
\end{aligned}
$$

Nessa equação $c_{i}=c\left(\zeta_{i}\right)$ é o termo livre referente ao nó $i, u_{i}^{N T}=u\left(\varsigma_{i}, t_{F}\right)$ é o valor do potencial no ponto $i$ (interno ou externo) no tempo $t^{N T}, t_{0}^{k}$ é o tempo inicial do intervalo $k$ e $t_{f}^{k}$ é o tempo final do intervalo $k$. Passando a parcela dependente de $q^{*}$ para o lado direito da igualdade, invertendo a ordem do somatório e evidenciando o somatório referente ao tempo temse: 


$$
\begin{aligned}
c_{i}(\varsigma) u_{i}^{N T}\left(\varsigma, t_{F}\right) & =\sum_{k=1}^{N T}\left[\sum_{j=1}^{N E} q_{j}^{k} \int_{\Gamma_{j}} \phi_{j}(\xi) \int_{t_{0}^{k}}^{t_{f}^{k}} \kappa u^{*}\left(\varsigma, x, t_{F}, t\right) d t d \Gamma_{j}\right. \\
& \left.-\sum_{j=1}^{N E} u_{j}^{k} \int_{\Gamma_{j}} \phi_{j}(\xi) \int_{t_{0}^{k}}^{t_{f}^{k}} \kappa q^{*}\left(\varsigma, x, t_{F}, t\right) d t d \Gamma_{j}\right]
\end{aligned}
$$

A Equação (2.139) pode ser reescrita como:

$c_{i}(\varsigma) u_{i}^{N T}\left(\varsigma, t_{F}\right)=\sum_{k=1}^{N T}\left[\sum_{j=1}^{N E} q_{j}^{k} \int_{\Gamma_{j}} \phi_{j}(\xi) \kappa U_{k}^{*}(\varsigma, x) d \Gamma_{j}-\sum_{j=1}^{N E} u_{j}^{k} \int_{\Gamma_{j}} \phi_{j}(\xi) \kappa Q_{k}^{*}(\varsigma, x) d \Gamma_{j}\right]$

sendo:

$U_{k}^{*}(\varsigma, x)=\int_{t_{0}^{k}}^{t_{f}^{k}} u^{*}\left(s, x, t_{F}, t\right) d t=\int_{t_{0}^{k}}^{t_{f}^{k}} \frac{1}{4 \pi \kappa \tau} \exp \left[-\frac{r^{2}}{4 \kappa \tau}\right] d t$

$Q_{k}^{*}(\varsigma, x)=\int_{t_{0}^{k}}^{t_{f}^{k}} q^{*}\left(\varsigma, x, t_{F}, t\right) d t=\int_{t_{0}^{k}}^{t_{f}^{k}} \frac{r \frac{\partial r}{\partial \eta}}{8 \pi \kappa^{2} \tau^{2}} \exp \left[-\frac{r^{2}}{4 \kappa \tau}\right] d t$

As integrais nas Equações (2.141) e (2.142) podem ser resolvidas analiticamente. Para a Equação (2.141) tem-se que realizar uma mudança de variáveis fazendo $x=\frac{r^{2}}{4 \kappa \tau}$ e $d t=\frac{4 \kappa \tau^{2}}{r^{2}} d x$, assim:

$$
\begin{gathered}
U_{k}^{*}(\varsigma, x)=\int_{t_{0}^{k}}^{t_{f}^{k}} \frac{1}{4 \pi \kappa \tau} \exp \left[-\frac{r^{2}}{4 \kappa \tau}\right] d t=\frac{1}{4 \pi \kappa} \int_{t_{0}^{k}}^{t_{f}^{k}} \frac{1}{\tau} \exp \left[-\frac{r^{2}}{4 \kappa \tau}\right] \frac{4 \kappa \tau^{2}}{r^{2}} d x \\
=\frac{1}{4 \pi \kappa} \int_{a_{0}^{k}}^{a_{f}^{k}} e^{-x} \frac{1}{x} d x=\frac{1}{4 \pi \kappa}\left[E_{1}\left(a_{0}^{k}\right)-E_{1}\left(a_{f}^{k}\right)\right]
\end{gathered}
$$

sendo $a_{f}^{k}=\frac{r^{2}}{4 \kappa\left(t_{F}-t_{f}^{k}\right)}, a_{0}^{k}=\frac{r^{2}}{4 \kappa\left(t_{F}-t_{0}^{k}\right)}$ e $E_{1}($.$) a função exponencial-integral conforme: E_{1}(z)=$ $\int_{z}^{\infty} \frac{e^{-t}}{t} d t$. Para a Equação (2.142) tem-se:

$Q_{k}^{*}(\varsigma, x)=\int_{t_{0}^{k}}^{t_{f}^{k}} \frac{r \frac{\partial r}{\partial \eta}}{8 \pi \kappa^{2} \tau^{2}} \exp \left[-\frac{r^{2}}{4 \kappa \tau}\right] d t=\frac{1}{2 \pi \kappa r} \frac{\partial r}{\partial \eta}\left[\exp \left(-a_{0}^{k}\right)-\exp \left(-a_{f}^{k}\right)\right]$

\subsubsection{Subtração de singularidade}

De forma análoga ao que foi feito na formulação para o regime estacionário, as integrais que contém as soluções fundamentais, agora dependentes do tempo, precisam ser avaliadas com relação a sua singularidade. O núcleo contendo a solução fundamental $q^{*}$ para o caso transiente é não singular, como no caso estacionário. Contudo, o núcleo $u^{*}$ precisa ser regularizado. A singularidade surge em $U_{k}^{*}$ quando $k=1$, ou seja, no primeiro intervalo de tempo e quando o 
ponto fonte aproxima-se do ponto campo, ou seja, quando $r \rightarrow 0$. Assim, quando $k=1$ tem-se na Equação (2.143):

$U_{1}^{*}(\varsigma, x)=\frac{1}{4 \pi \kappa}\left[E_{1}\left(a_{0}^{1}\right)-E_{1}\left(a_{f}^{1}\right)\right]$

sendo:

$a_{f}^{1}=\frac{r^{2}}{4 \kappa\left(t_{F}-t_{f}^{1}\right)}$

$a_{0}^{1}=\frac{r^{2}}{4 \kappa\left(t_{F}-t_{0}^{1}\right)}$

As variáveis $a_{f}^{k}$ e $a_{0}^{k}$ assumem sempre valores não negativos, uma vez que $\kappa>0, r \geq 0$ e $t_{F} \geq t_{f}^{k}>t_{0}^{k}$. Na Equação (2.146) quando $r$ vale zero e $t_{f}^{1} \rightarrow t_{F}, a_{f}^{1} \rightarrow+\infty$. Assim, a função exponencial-integral é avaliada em $+\infty$, o que resulta em um valor igual a zero, conforme pode ser visto na Figura 2.13.

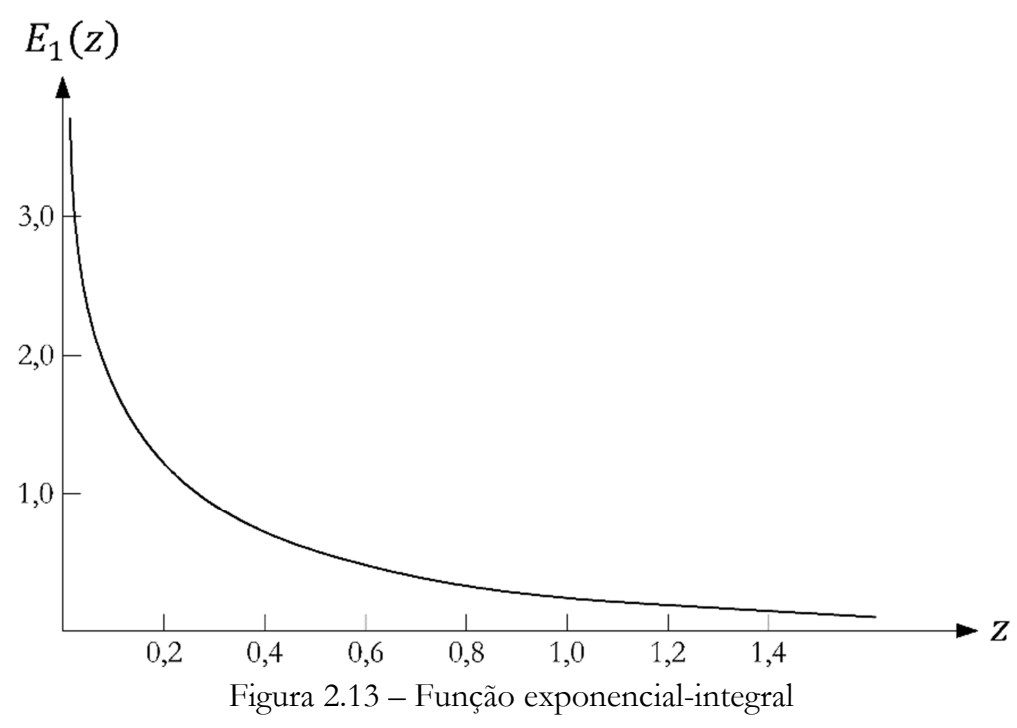

$\mathrm{Na}$ Equação (2.147) quando $r$ vale zero, $a_{0}^{1} \rightarrow 0$, uma vez que o denominador $\left(t_{F}-t_{0}^{1}\right)$ sempre será maior do que zero $\left(t_{F} \geq t_{f}^{1}>t_{0}^{1}\right)$. Assim, a função exponencial-integral terá como argumento o valor zero, o que resulta em uma singularidade. Matematicamente tem-se:

$U_{1}^{*}(\varsigma, x)=\frac{1}{4 \pi \kappa}\left[E_{1}(0)-E_{1}(+\infty)\right]=\frac{1}{4 \pi \kappa}\left[E_{1}(0)\right]$

A singularidade que surge nessa equação é do tipo logarítmica, como se pode constatar realizando uma expansão em série. Tal expansão para intervalos distintos do argumento da função exponencial-integral, $0 \leq z \leq 1$ e $1<z<\infty$ pode ser vista em Abramowitz e Stegun (1965). Assim, o núcleo que contém $u^{*}$ pode ser regularizado por meio da seguinte equação: 


$$
\int_{\Gamma_{j}} U_{1}^{*}(\varsigma, x) d \Gamma_{j}=\frac{1}{4 \pi \kappa} \int_{\Gamma_{j}}\left[E_{1}\left(a_{0}^{1}\right)-\ln \left(a_{0}^{1^{*}}\right)\right] d \Gamma_{j}+\frac{1}{4 \pi \kappa} \int_{\Gamma_{j}} \ln \left(a_{0}^{1^{*}}\right) d \Gamma_{j}
$$

Lembrando que $r^{*}=|J| \varepsilon=|J|\left|\xi-\xi_{0}\right|$ e que $d \Gamma=J d \xi$, tem-se:

$$
\begin{aligned}
\int_{\Gamma_{j}} U_{1}^{*}(\varsigma, x) d \Gamma_{j} & =\frac{1}{4 \pi \kappa} \int_{-1}^{1} E_{1}\left(a_{0}^{1}\right) \phi(\xi) J(\xi) d \xi-\frac{1}{4 \pi \kappa} \int_{-1}^{1} \ln \left(a_{0}^{1^{*}}\right) \phi\left(\xi_{0}\right) J\left(\xi_{0}\right) d \xi \\
& +\frac{1}{4 \pi \kappa} \int_{-1}^{1} \ln \left(a_{0}^{1^{*}}\right) \phi\left(\xi_{0}\right) J\left(\xi_{0}\right) d \xi
\end{aligned}
$$

sendo:

$a_{0}^{1^{*}}=\frac{\left(r^{*}\right)^{2}}{4 \kappa\left(t_{F}-t_{0}^{1}\right)}=\frac{\left(\left|J\left(\xi_{0}\right)\right||\varepsilon|\right)^{2}}{4 \kappa\left(t_{F}-t_{0}^{1}\right)}$

$\mathrm{Na}$ Equação (2.150) as duas primeiras integrais do lado direito da igualdade são limitadas e não são mais singulares, portanto são avaliadas numericamente por meio da quadratura de Gauss-Legendre. Já a última integral é avaliada analiticamente. Define-se por conveniência que essa última integral seja definida por $I$.

$I=\frac{1}{4 \pi \kappa} \int_{-1}^{1} \ln \left(a_{0}^{1^{*}}\right) \phi\left(\xi_{0}\right) J\left(\xi_{0}\right) d \xi$

Mudando o domínio de integração de $d \xi$ para $d \varepsilon$ e consequentemente seus intervalos de integração, tem-se:

$I=\frac{1}{4 \pi \kappa} \int_{-1-\xi_{0}}^{1-\xi_{0}} \ln \left[\frac{\left(\left|J\left(\xi_{0}\right) \| \varepsilon\right|\right)^{2}}{4 \kappa\left(t_{F}-t_{0}^{1}\right)}\right] \phi\left(\xi_{0}\right) J\left(\xi_{0}\right) d \varepsilon$

Por simplicidade, considerando-se $t_{0}^{1}=0$, tem-se:

$I=\frac{1}{4 \pi \kappa} \int_{-1-\xi_{0}}^{1-\xi_{0}} 2 \ln \left(\left|J\left(\xi_{0}\right)\right||\varepsilon|\right) \phi\left(\xi_{0}\right) J\left(\xi_{0}\right) d \varepsilon-\frac{1}{4 \pi \kappa} \int_{-1-\xi_{0}}^{1-\xi_{0}} \ln \left(4 \kappa t_{F}\right) \phi\left(\xi_{0}\right) J\left(\xi_{0}\right) d \varepsilon$

Sabendo que $\int \ln (a u) d u=u \ln (|a u|)-u$, sendo $a$ uma constante, analisa-se a integral $I$ no sentido do valor principal de Cauchy conforme:

$$
\begin{array}{r}
V P C=\lim _{\varepsilon \rightarrow 0}\left\{\frac{1}{4 \pi \kappa} \int_{-1-\xi_{0}}^{-\varepsilon} 2 \ln \left(\left|J\left(\xi_{0}\right)\right||\varepsilon|\right) \phi\left(\xi_{0}\right) J\left(\xi_{0}\right) d \varepsilon+\frac{1}{4 \pi \kappa} \int_{+\varepsilon}^{1-\xi_{0}} 2 \ln \left(\left|J\left(\xi_{0}\right)\right||\varepsilon|\right) \phi\left(\xi_{0}\right) J\left(\xi_{0}\right) d \varepsilon\right. \\
\left.-\frac{1}{4 \pi \kappa} \int_{-1-\xi_{0}}^{-\varepsilon} \ln \left(4 \kappa t_{F}\right) \phi\left(\xi_{0}\right) J\left(\xi_{0}\right) d \varepsilon-\frac{1}{4 \pi \kappa} \int_{+\varepsilon}^{1-\xi_{0}} \ln \left(4 \kappa t_{F}\right) \phi\left(\xi_{0}\right) J\left(\xi_{0}\right) d \varepsilon\right\} \rightarrow \\
V P C=\lim _{\varepsilon \rightarrow 0}\left\{\frac { 1 } { 4 \pi \kappa } \phi ( \xi _ { 0 } ) J ( \xi _ { 0 } ) \left[\int_{-1-\xi_{0}}^{-\varepsilon} 2 \ln \left(\left|J\left(\xi_{0}\right) \| \varepsilon\right|\right) d \varepsilon+\int_{+\varepsilon}^{1-\xi_{0}} 2 \ln \left(\left|J\left(\xi_{0}\right) \| \varepsilon\right|\right) d \varepsilon\right.\right. \\
\left.\left.-\int_{-1-\xi_{0}}^{-\varepsilon} \ln \left(4 \kappa t_{F}\right) \phi\left(\xi_{0}\right) J\left(\xi_{0}\right) d \varepsilon-\int_{+\varepsilon}^{1-\xi_{0}} \ln \left(4 \kappa t_{F}\right) d \varepsilon\right]\right\}
\end{array}
$$

Convenientemente cada uma das integrais da última equação são denominadas de $I_{1}$ a $I_{4} \mathrm{e}$ são avaliadas individualmente. Reescrevendo a Equação (2.155) tem-se: 


$$
V P C=\lim _{\varepsilon \rightarrow 0}\left\{\frac{1}{4 \pi \kappa} \phi\left(\xi_{0}\right) J\left(\xi_{0}\right)\left[I_{1}+I_{2}-\left(I_{3}+I_{4}\right)\right]\right\}
$$

Assim, avaliando $I_{1}$ :

$$
I_{1}=2\left[\varepsilon \ln \left(\left|J\left(\xi_{0}\right) \varepsilon\right|\right)\right]_{-1-\xi_{0}}^{-\varepsilon}=2\left\{-\varepsilon \ln \left(\left|J\left(\xi_{0}\right) \varepsilon\right|\right)+\varepsilon-\left[\left(-1-\xi_{0}\right) \ln \left(\left|J\left(\xi_{0}\right)\left(-1-\xi_{0}\right)\right|\right)+1+\xi_{0}\right]\right\}
$$

Avaliando $I_{2}$ :

$$
I_{2}=2\left[\varepsilon \ln \left(\left|J\left(\xi_{0}\right) \varepsilon\right|\right)\right]_{\varepsilon}^{1-\xi_{0}}=2\left\{\left(1-\xi_{0}\right) \ln \left(\left|J\left(\xi_{0}\right)\left(1-\xi_{0}\right)\right|\right)-1+\xi_{0}-\left[\varepsilon \ln \left(\left|J\left(\xi_{0}\right) \varepsilon\right|\right)-\varepsilon\right]\right\}
$$

Avaliando $I_{3}$ :

$$
I_{3}=\ln \left(4 \kappa t_{F}\right)\left[-\varepsilon+1+\xi_{0}\right]
$$

Avaliando $I_{4}$ :

$$
I_{4}=\ln \left(4 \kappa t_{F}\right)\left[1-\xi_{0}-\varepsilon\right]
$$

Somando $I_{1}$ e $I_{2}$ tem-se:

$$
\begin{gathered}
I_{1}+I_{2}=2\left\{-\varepsilon \ln \left(\left|J\left(\xi_{0}\right) \varepsilon\right|\right)+\varepsilon+\left(1+\xi_{0}\right) \ln \left(\left|J\left(\xi_{0}\right)\left(-1-\xi_{0}\right)\right|\right)-1-\xi_{0}\right. \\
\left.+\left(1-\xi_{0}\right) \ln \left(\left|J\left(\xi_{0}\right)\left(1-\xi_{0}\right)\right|\right)-1+\xi_{0}-\varepsilon \ln \left(\left|J\left(\xi_{0}\right) \varepsilon\right|\right)+\varepsilon\right\} \rightarrow \\
I_{1}+I_{2}=2\left\{-2 \varepsilon \ln \left(\left|J\left(\xi_{0}\right) \varepsilon\right|\right)+2 \varepsilon-2+\left(1+\xi_{0}\right) \ln \left(\left|J\left(\xi_{0}\right)\left(-1-\xi_{0}\right)\right|\right)\right. \\
\left.+\left(1-\xi_{0}\right) \ln \left(\left|J\left(\xi_{0}\right)\left(1-\xi_{0}\right)\right|\right)\right\}
\end{gathered}
$$

Somando $I_{3}$ e $I_{4}$ tem-se:

$$
I_{3}+I_{4}=\ln \left(4 \kappa t_{F}\right)\left[-\varepsilon+1+\xi_{0}+1-\xi_{0}-\varepsilon\right]=\ln \left(4 \kappa t_{F}\right)[-2 \varepsilon+2]
$$

Pelo teorema de L'Hôpital tem-se que :

$$
\lim _{\varepsilon \rightarrow 0}\left\{\varepsilon \ln \left(J\left(\xi_{0}\right) \varepsilon\right)\right\}=0
$$

Portanto o limite da Equação (2.156), explicitando os termos $I_{1}$ a $I_{4}$, resulta:

$$
\begin{aligned}
V P C=\frac{1}{4 \pi \kappa} & \phi\left(\xi_{0}\right) J\left(\xi_{0}\right)\left\{-4+2\left(1+\xi_{0}\right) \ln \left(\left|J\left(\xi_{0}\right)\left(-1-\xi_{0}\right)\right|\right)\right. \\
& \left.+2\left(1-\xi_{0}\right) \ln \left(\left|J\left(\xi_{0}\right)\left(1-\xi_{0}\right)\right|\right)-2 \ln \left(4 \kappa t_{F}\right)\right\}
\end{aligned}
$$

Assim, tem-se que:

$$
\begin{aligned}
V P C=\frac{1}{2 \pi \kappa} \phi & \left(\xi_{0}\right) J\left(\xi_{0}\right)\left\{-2+\left(1+\xi_{0}\right) \ln \left(\left|J\left(\xi_{0}\right)\left(-1-\xi_{0}\right)\right|\right)\right. \\
& \left.+\left(1-\xi_{0}\right) \ln \left(\left|J\left(\xi_{0}\right)\left(1-\xi_{0}\right)\right|\right)-\ln \left(4 \kappa t_{F}\right)\right\}
\end{aligned}
$$

A Equação (2.165) é válida para os casos onde o ponto fonte não encontra-se nos extremos do elemento, ou seja, em $\xi_{0}= \pm 1$. Em outras palavras, a Equação (2.165) é válida apenas para elementos descontínuos. Caso sejam utilizados elementos contínuos, deve-se tomar apenas a parte finita dessa equação, ou seja:

$$
V P C=\frac{1}{2 \pi \kappa} \phi\left(\xi_{0}\right) J\left(\xi_{0}\right)\left\{-2+2 \ln \left(\left|2 J\left(\xi_{0}\right)\right|\right)-\ln \left(4 \kappa t_{F}\right)\right\}
$$




\subsubsection{Implementação computacional}

A equação integral de contorno que descreve o problema da difusão com condições iniciais nulas, escrita de forma discretizada é dada pela Equação (2.140), repetida aqui por conveniência:

$c_{i}(\varsigma) u_{i}^{N T}\left(\varsigma, t_{F}\right)=\sum_{k=1}^{N T}\left[\sum_{j=1}^{N E} q_{j}^{k} \int_{\Gamma_{j}} \phi_{j}(\xi) \kappa U_{k}^{*}(\varsigma, x) d \Gamma_{j}-\sum_{j=1}^{N E} u_{j}^{k} \int_{\Gamma_{j}} \phi_{j}(\xi) \kappa Q_{k}^{*}(\varsigma, x) d \Gamma_{j}\right]$

Como condições de contorno, deve-se saber de antemão metade dos valores entre fluxo $(q)$ e potencial $(u)$ em cada um dos nós $i$ do contorno em cada instante de tempo $t$, de forma que para cada passo de tempo seja possível montar um sistema de equações que possua um número de incógnitas igual ao número de equações disponíveis. Reescrevendo a Equação (2.167) utilizando-se da quadratura de Gauss-Legendre para a integração no espaço, tem-se:

$c_{i}(\varsigma) u_{i}^{N T}\left(\varsigma, t_{F}\right)=\sum_{k=1}^{N T}\left[\sum_{j=1}^{N E} q_{j}^{k} \sum_{l=1}^{N G} \phi_{j}(\xi) \kappa U_{k}^{*}(\xi) J(\xi) w_{l}-\sum_{j=1}^{N E} u_{j}^{k} \sum_{l=1}^{N G} \phi_{j}(\xi) \kappa Q_{k}^{*}(\xi) J(\xi) w_{l}\right]$

sendo $w_{l}$ o peso de Gauss de um ponto $l$. A Equação (2.168) pode ser reescrita de forma compacta, considerando que os nós estejam posicionados no contorno, ou seja, $c_{i}(\varsigma)=0,5$.

$0,5 u_{i}^{N T}=\sum_{k=1}^{N T}\left[\sum_{j=1}^{N E} G_{i j}^{k} q_{j}^{k}-\sum_{j=1}^{N E} \widehat{H}_{i j}^{k} u_{j}^{k}\right]$

sendo $q_{j}^{k}$ e $u_{j}^{k}$ os valores de fluxo e de potencial, respectivamente, em cada nó de cada elemento em cada intervalo discretizado de tempo, admitidos como constantes dentro de um mesmo intervalo de tempo. Os termos $G_{i j}^{k}$ e $\widehat{H}_{i j}^{k}$ são dados por:

$G_{i j}^{k}=\sum_{l=1}^{N G} \phi_{j}(\xi) \kappa U_{k}^{*}(\xi) J(\xi) w_{l}$

$\widehat{H}_{i j}^{k}=\sum_{l=1}^{N G} \phi_{j}(\xi) \kappa Q_{k}^{*}(\xi) J(\xi) w_{l}$

$H_{i j}^{k}=\left\{\begin{array}{cc}\widehat{H}_{i j}^{k}+0,5 & \text { se } i=j \text { e } k=1 \\ \widehat{H}_{i j}^{k} & \text { nos demais casos }\end{array}\right.$

A Equação (2.169) é utilizada em cada um dos nós dos elementos que discretizam o contorno, em cada intervalo de tempo discretizado $k$, sendo que cada nó é interpretado como um nó fonte. $\mathrm{Na}$ Equação (2.170) os valores das soluções fundamentais integradas no tempo analiticamente, ou seja, $U_{k}^{*}(\xi)$ e $Q_{k}^{*}(\xi)$, são dados pelas Equações (2.143) e (2.144). O termo livre 
igual a $c_{i}(\varsigma)=0,5$ é somado a diagonal da matriz $H_{i j}^{k}$ somente quando $k=1$, ou seja, no primeiro intervalo de tempo. Além disso, quando o nó fonte estiver integrando o elemento ao qual ele pertence, no primeiro intervalo de tempo, utiliza-se o método da subtração de singularidade para regularizar o núcleo $U_{1}^{*}$, conforme descrito pelas Equações (2.150) e (2.165). A Equação (2.169) é então escrita para cada um dos nós $i$ e para um dado número de passos de tempo $N T$, resultando em um sistema de equações que possui o seguinte formato:

$\sum_{k=1}^{N T}[H]^{k}\{u\}^{N T-k+1}=\sum_{k=1}^{N T}[G]^{k}\{q\}^{N T-k+1}$

As matrizes $[H]$ e $[G]$ contém os núcleos integrais compostos pelas soluções fundamentais $q^{*}$ e $u^{*}$ respectivamente, para cada um dos intervalos de tempo $k$ de 1 a $N T$, já integradas no tempo. Os vetores $\{u\}$ e $\{q\}$ contém os valores de potencial e de fluxo nos nós do contorno, respectivamente, para cada um dos intervalos de tempo. Destaca-se que as condições de contorno do problema, ou seja, o conhecimento prévio dos valores do potencial e do fluxo em determinados pontos do contorno, em cada intervalo de tempo, são utilizados na montagem dos vetores $\{u\}$ e $\{q\}$. Além disso, com o processo de marcha no tempo, todos os valores de $\{u\}$ e $\{q\}$ são conhecidos em instantes de tempo anteriores a $N T$, conforme será explicado a seguir.

Particularizando a Equação (2.172) para $N T=1$ tem-se:

$[H]^{1}\{u\}^{1}=[G]^{1}\{q\}^{1}$

Esse sistema de equações possui formato idêntico àquele do regime estacionário, sendo resolvido de forma similar, a partir da metodologia de troca de colunas entre as matrizes $[H]^{1} \mathrm{e}$ $[G]^{1}$ e troca de posições entre os vetores $\{u\}^{1}$ e $\{q\}^{1}$, conforme já descrito na seção 2.2.7. Após resolver o sistema de equações dado pela Equação (2.173) todos os valores numéricos de $\{u\}^{1}$ e $\{q\}^{1}$ são conhecidos e pode-se avançar no tempo. Assim, para $N T=2$, na Equação (2.172) temse:

$[H]^{1}\{u\}^{2}+[H]^{2}\{u\}^{1}=[G]^{1}\{q\}^{2}+[G]^{2}\{q\}^{1}$

Essa Equação pode ser reescrita como:

$[H]^{1}\{u\}^{2}=[G]^{1}\{q\}^{2}+\{h\}^{2}$

Sendo:

$\{h\}^{2}=[G]^{2}\{q\}^{1}-[H]^{2}\{u\}^{1}$

Destaca-se que o vetor $\{h\}^{2}$ é calculado a partir das matrizes $[G]^{2}$ e $[H]^{2}$ e dos vetores $\{q\}^{1}$ e $\{u\}^{1}$, que foram todos calculados no passo de tempo $k=1$. Na Equação (2.175), de forma análoga ao que foi feito para $k=1$, trocam-se as colunas entre as matrizes $[H]^{1} \mathrm{e}[G]^{1} \mathrm{e}$ 
as posições entre os vetores $\{u\}^{2}$ e $\{q\}^{2}$ e resolve-se o sistema de equações. Após tal procedimento, todos os valores numéricos de $\{u\}^{2}$ e $\{q\}^{2}$ são conhecidos e pode-se novamente avançar no tempo e continuar o processo de forma análoga. Assim, a Equação (2.172) pode ser reescrita da seguinte forma:

$[H]^{1}\{u\}^{N T}=[G]^{1}\{q\}^{N T}+\{h\}^{N T}$

sendo $\{h\}^{N T}$ um vetor que contém a contribuição da história anterior dos potenciais e fluxos nos nós do contorno, podendo ser reescrito da seguinte forma:

$\{h\}^{N T}=\sum_{k=2}^{N T}\left([G]^{k}\{q\}^{N T-k+1}-[H]^{k}\{u\}^{N T-k+1}\right)$

Explicitando os termos da Equação (2.178) tem-se:

$$
\begin{gathered}
\{h\}^{N T}=\left([G]^{2}\{q\}^{N T-1}-[H]^{2}\{u\}^{N T-1}\right)+\left([G]^{3}\{q\}^{N T-2}-[H]^{3}\{u\}^{N T-2}\right)+\cdots \\
+\left([G]^{N T-1}\{q\}^{2}-[H]^{N T-1}\{u\}^{2}\right)+\left([G]^{N T}\{q\}^{1}-[H]^{N T}\{u\}^{1}\right)
\end{gathered}
$$

Assim, o vetor $\{h\}^{N T}$ é calculado a partir de todas as matrizes $[G]^{k}$ e $[H]^{k}$ e de todos os vetores $\{q\}^{N T-k+1}$ e $\{u\}^{N T-k+1}$. As matrizes $[G]^{k}$ e $[H]^{k}$ dependem somente da geometria do problema e do passo de tempo, de $k=2$ a $k=N T$. Os vetores $\{q\}^{N T-k+1}$ e $\{u\}^{N T-k+1}$ dependem do fluxo e do potencial nos nós do contorno em passos de tempo anteriores a $N T$, isto é, do intervalo de 1 até o intervalo $N T-1$.

Os valores dos potenciais em pontos internos podem ser determinados empregando-se a Equação (2.168) com $c_{i}(\varsigma)=1$. Procedendo de forma análoga ao que foi apresentado anteriormente obtém-se:

$\left\{u_{i n t}\right\}^{N T}=\sum_{k=1}^{N T}\left(\left[G^{\prime}\right]^{k}\{q\}^{N T-k+1}-\left[H^{\prime}\right]^{k}\{u\}^{N T-k+1}\right)$

sendo $\left\{u_{i n t}\right\}^{N T}$ o vetor que contém os potenciais nos pontos internos em um intervalo de tempo $N T$. Por sua vez $\{q\}^{N T-k+1}$ e $\{u\}^{N T-k+1}$ são os vetores que contém os fluxos e potenciais nos nós do contorno, com todos os seus valores numéricos já determinados em todos os intervalos de tempo até $N T$. As matrizes $\left[G^{\prime}\right]^{k}$ e $\left[H^{\prime}\right]^{k}$ são as matrizes que contém os núcleos integrais compostos pelas soluções fundamentais $q^{*}$ e $u^{*}$ para cada um dos intervalos de tempo até $N T$, calculadas agora considerando os pontos internos como sendo os pontos fonte e os pontos do contorno como sendo os pontos campo.

Vale destacar que a metade de todos os valores entre fluxo e potencial compõe as condições de contorno do problema e, portanto, seus valores numéricos são dados de entrada necessários. Tais valores numéricos são informados para todos os intervalos de tempo $k$ e são 
alocados já nos vetores $\{u\}^{k}$ e $\{q\}^{k}$. Com o processo de marcha no tempo, os valores numéricos, a priori desconhecidos nesses vetores, vão sendo alocados logo após a resolução do sistema de equações da Equação (2.172) para cada intervalo de tempo.

Outro ponto a ser observado é que as matrizes $[H]^{k}$ e $[G]^{k}$, necessárias em cada intervalo de tempo $k$, podem ter todos os seus valores numéricos determinados antes mesmo do início do processo de marcha no tempo se os passos de tempo forem de tamanho constante. Isso é possível de ser feito pois essas matrizes independem das incógnitas de fluxo e potencial.

Considerando-se que a maior parcela de tempo de processamento computacional ocorre justamente no cálculo dos temos das matrizes $[H]$ e $[G]$, tal estratégia para a construção dessas matrizes se mostra bastante vantajosa. Por exemplo, caso várias simulações sejam feitas variandose as condições de contorno, as matrizes $[H]$ e $[G]$ só precisarão ser construídas uma única vez para todos os intervalos de tempo na primeira simulação, sendo que nas demais simulações poderão ser reaproveitadas.

Deve-se tomado cuidado na seleção do valor do passo de tempo para simulações numéricas. Conforme o valor de incremento de tempo tende a zero, a solução fundamental $u^{*}$, dada pela Equação (2.127), se torna cada vez menos suave, sendo o seu limite uma função delta de Dirac. A dificuldade de integrar numericamente uma função com tal comportamento levou alguns autores, como Chaudouet (1987) e Morvan (1988), a constatar nesse ponto um problema de estabilidade, definindo um limite inferior de tamanho de passo de tempo abaixo do qual a solução é instável. O correto tratamento para esse problema é simplesmente melhorar o procedimento de integração numérica. O principal problema com relação ao esquema de avanço no tempo apresentado é a necessidade de avaliações repetidas dos valores de contorno, que apresentam dependência do histórico de valores passados, através de integrais de convolução para cada passo de tempo. Assim, o trabalho computacional aumenta substancialmente com o avanço do tempo. Algoritmos de truncamento, que somente avaliam de forma aproximada a influência de passos iniciais após decorrido algum tempo, foram desenvolvidos por Davey e Hinduja (1989) e Demiel e Wang (1987). A ideia básica é dividir as integrais de convolução em integrais de história-próxima e de história-afastada, sendo que àquelas de história-afastada se beneficiam do decaimento da solução fundamental para assim avaliar somente alguns poucos passos de tempo. Uma formulação indireta alternativa foi proposta por Greengard e Strain (1990), onde a solução fundamental é representada por termos de uma série de Fourier e o método de imagens. Embora a representação por si só não elimine a história no tempo, o fato inerente de que os coeficientes da série de Fourier, em qualquer passo de tempo, possam ser avaliados recursivamente a partir daqueles em passos anteriores, proporciona uma substancial 
economia em termos computacionais. Ideias similares foram usadas por Strain (1992) para problemas de crescimento de cristal e estendidos em abordagens diretas por Ibañez e Power (2000) (WROBEL, 2002).

Um fluxograma da implementação computacional do MEC para problemas de potencial em regime transiente é ilustrado na Figura 2.14.

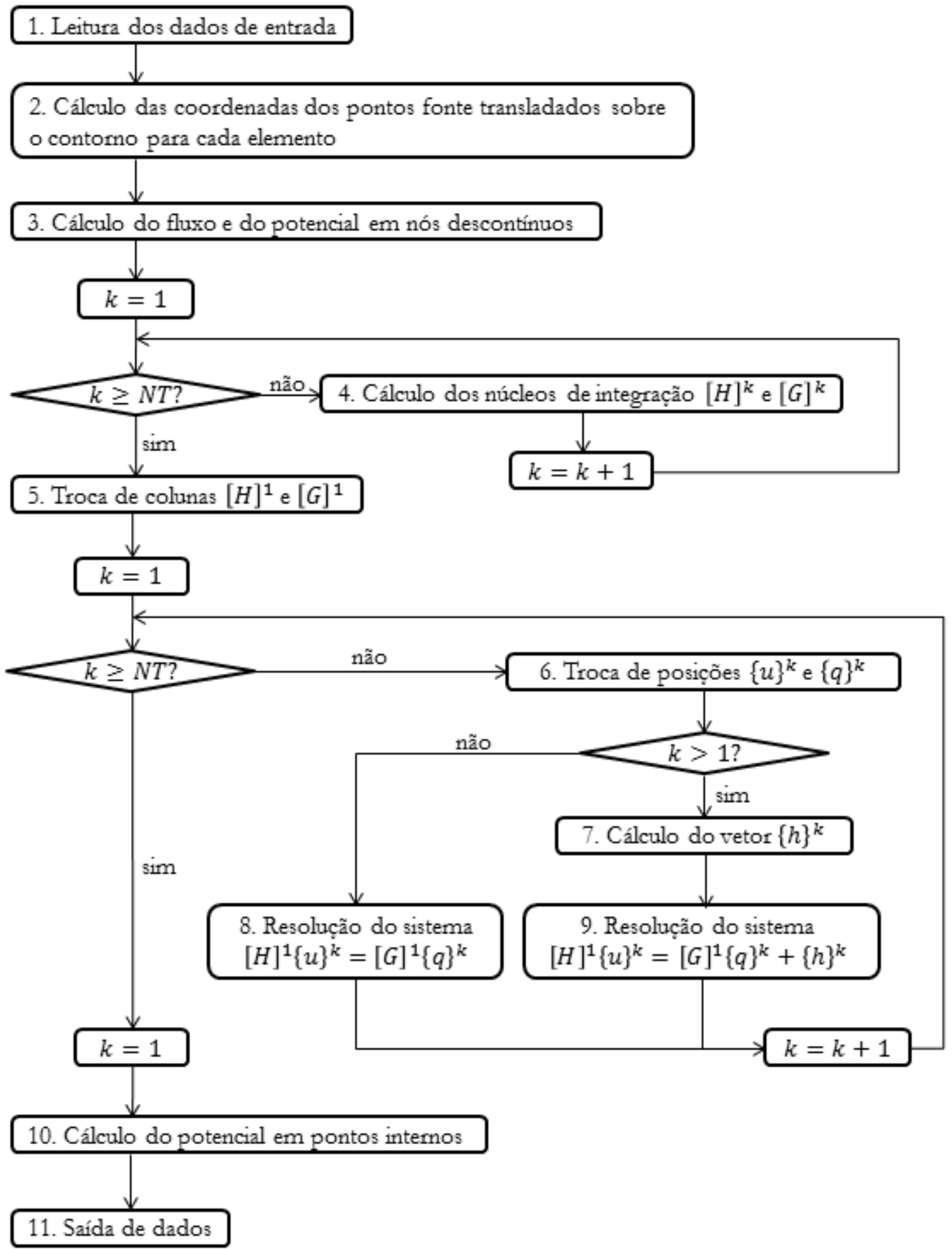

Figura 2.14 - Fluxograma do programa via MEC para problemas de difusão transiente 
Da mesma forma que no caso estacionário, no passo 3 da Figura 2.14 vale comentar que, pelo fato dos nós de interseção entre elementos serem descontinuados e, portanto, transladados para o interior dos elementos, é necessário realizar uma correção nos valores de potencial e fluxo nesses nós. Tal correção é feita por meio da interpolação dos valores das grandezas do contorno dos demais nós pertencentes ao elemento. Essa correção deve ser feita para todos os passos de tempo. Além disso, destaca-se que no passo 10 do fluxograma representado na Figura 2.14 há um laço de procedimentos a serem executados a cada passo de tempo incluindo a montagem das matrizes $\left[H^{\prime}\right]^{k}$ e $\left[G^{\prime}\right]^{k}$, conforme já especificado anteriormente.

\subsection{Exemplos de aplicação}

Nesse tópico são apresentados seis exemplos envolvendo a aplicação da formulação do método dos elementos de contorno (MEC) a problemas de potencial. Os primeiros dois exemplos tratam de problemas de potencial em regime estacionário. Os outros quatro exemplos tratam de problemas de potencial em regime transiente. Tais exemplos tiveram por objetivo validar o modelo implementado computacionalmente, por meio de comparações com resultados analíticos disponíveis na literatura e também demonstrar sua aplicabilidade e desempenho.

\subsubsection{Exemplo 1 - Regime estacionário: domínio quadrado}

O primeiro exemplo trata de um domínio quadrado medindo 4x4m (Figura 2.15 (a)), tendo sido discretizado de duas formas distintas: a primeira utilizando 16 elementos lineares isoparamétricos (Figura 2.15 (b)), totalizando 64 graus de liberdade e a segunda utilizando 4 elementos quárticos isoparamétricos (Figura 2.15 (c)), totalizando 40 graus de liberdade. Em ambas as discretizações a distância entre nós adjacentes é igual a $1 \mathrm{~m}$.

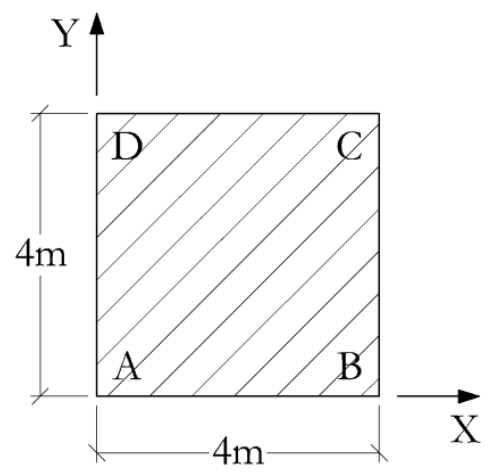

(a)

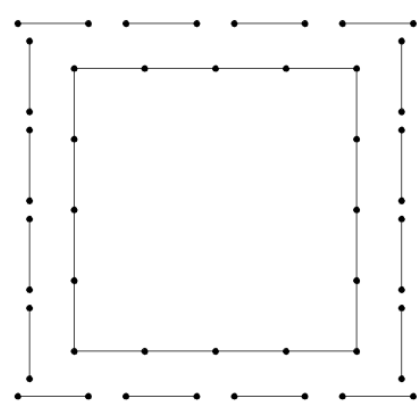

(b)

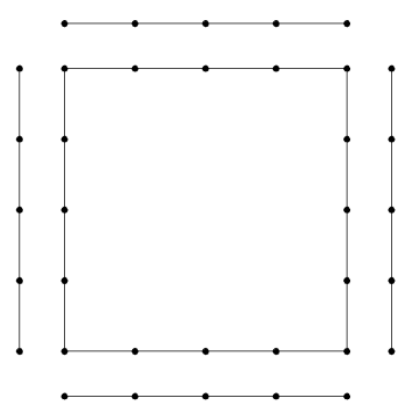

(c)

Figura 2.15 - Exemplo 1: geometria (a) e discretizações adotadas (b) e (c)

O potencial $u$ é conhecido nas faces $\mathrm{DA}$ e $\mathrm{BC}$, enquanto que o fluxo $q$ é conhecido nas faces $\mathrm{AB}$ e $\mathrm{CD}$, estando seus valores representados na Figura 2.16. 

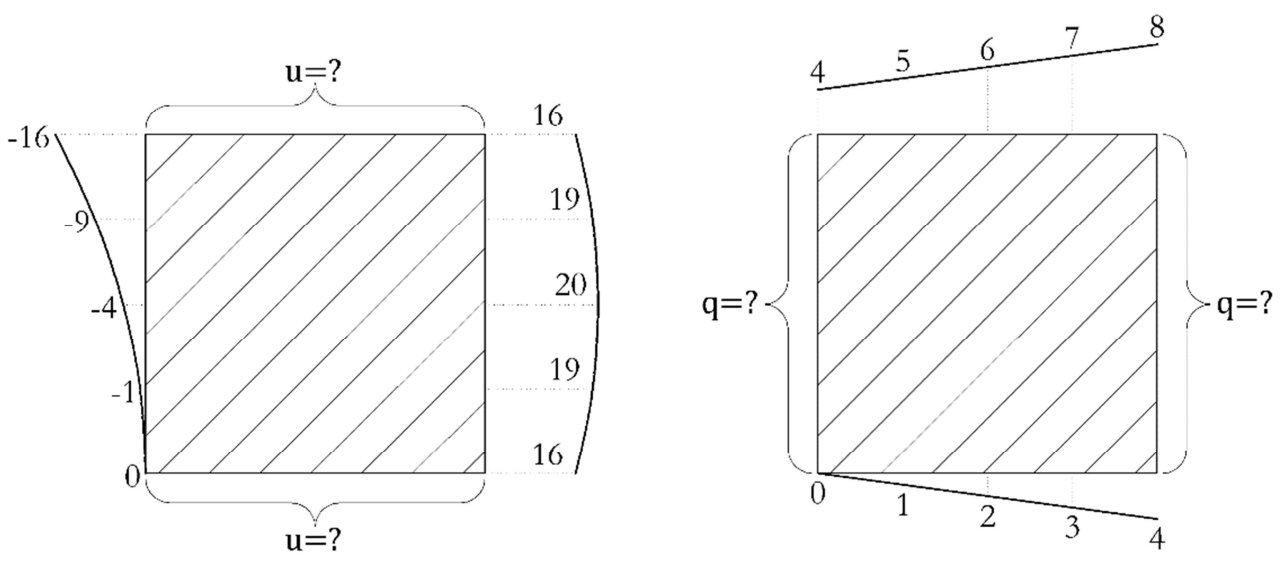

Figura 2.16 - Exemplo 1: condições de contorno

As condições de contorno foram impostas a partir da solução analítica do problema. Tal solução é dada pela equação:

$u(x, y)=x^{2}-y^{2}+x y$

As coordenadas cartesianas $x$ e $y$ têm como origem o vértice $A$, conforme representado na Figura 2.15 (a). Foram adotados 10 e 40 pontos de Gauss por elemento na integração numérica utilizando-se elementos lineares e quárticos, respectivamente. As duas análises resultaram num tempo de processamento computacional com mesma duração, sendo igual a 0,0156 segundos. Os resultados de fluxo e de potencial no contorno estão apresentados na Figura 2.17 e Figura 2.18, respectivamente.

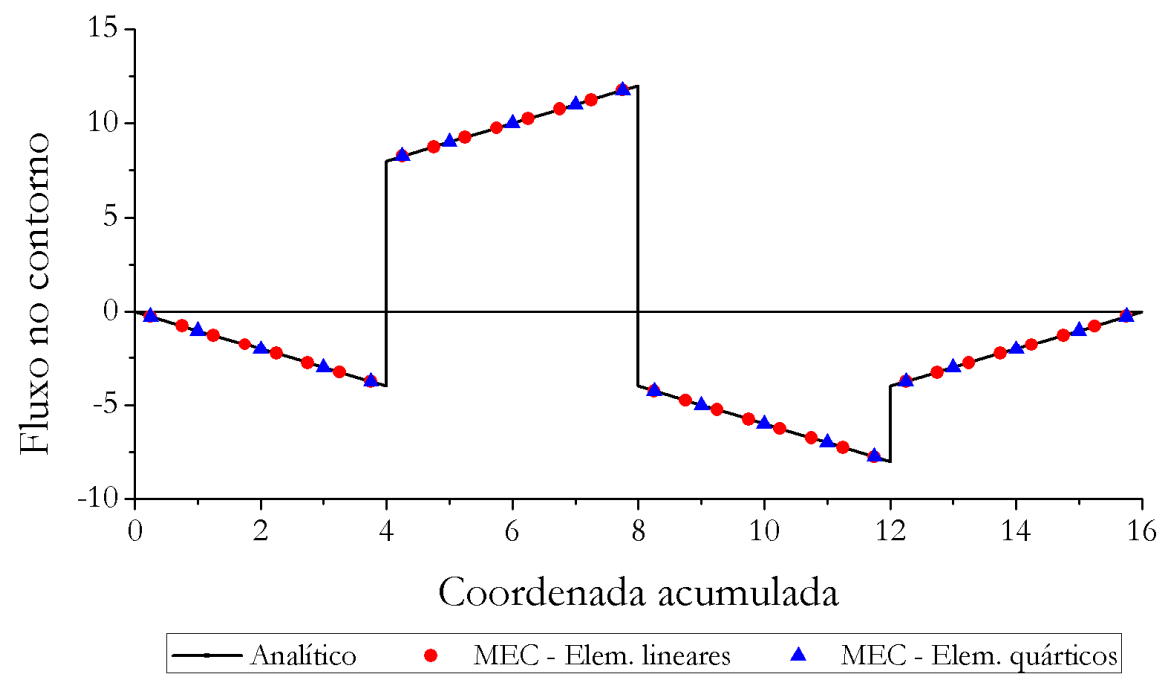

Figura 2.17 - Exemplo 1: fluxo no contorno 


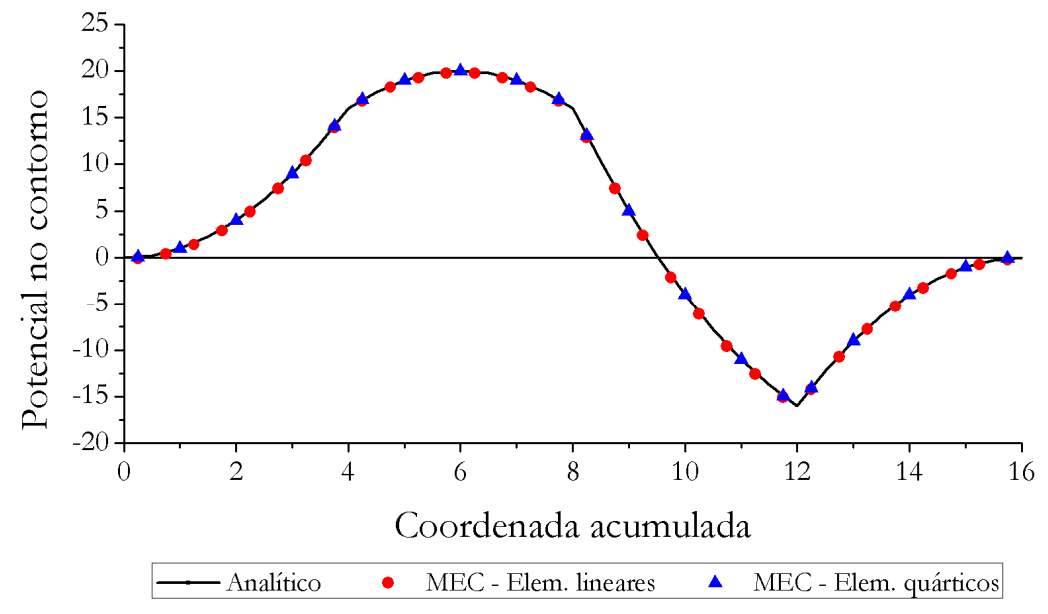

Figura 2.18 - Exemplo 1: potencial no contorno

Nos gráficos da Figura 2.17 e Figura 2.18, os valores no eixo das abscissas representam as coordenadas de contorno acumuladas, sendo que os vértices $\mathrm{A}, \mathrm{B}, \mathrm{C}$ e D possuem coordenadas iguais a 0 (ou 16), 4, 8 e 12, respectivamente. As análises demonstraram que as soluções numéricas das duas discretizações adotadas resultaram em uma plena concordância com a solução analítica. É interessante notar também nos gráficos da Figura 2.17 e Figura 2.18 que os pontos que representam as respostas via MEC para os nós comuns a dois elementos estão na verdade deslocados. Em outras palavras, os nós comuns a dois elementos não tiveram seus parâmetros (fluxo ou potencial) calculados exatamente nesse ponto comum. Isso está de acordo com o modelo adotado que utiliza elementos de contorno descontínuos.

\subsubsection{Exemplo 2 - Regime estacionário: domínio circular}

O segundo exemplo trata de um domínio circular vazado com raio externo igual a $b$ e raio interno igual a $a$. A priori são conhecidos os valores do potencial $u_{a}$ nos pontos localizados no contorno interno $\Gamma_{a}$ (igual para todos pontos) e os valores do fluxo $q_{b}$ nos pontos localizados no contorno externo $\Gamma_{b}$ (também igual para todos os pontos), conforme ilustrado na Figura 2.19.

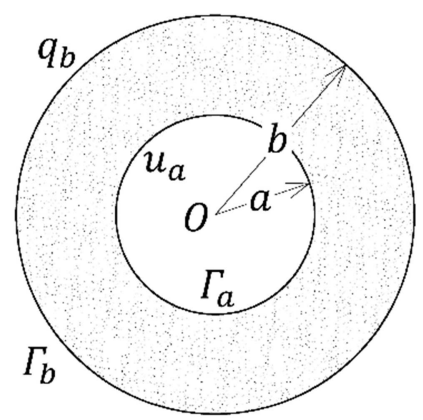

Figura 2.19 - Exemplo 2: geometria e condições de contorno do problema 
Tal problema possui solução analítica, sendo os valores de potencial e fluxo determinados em qualquer ponto conforme as equações (LIU, 2009):

$u(r)=u_{a}+q_{b} b \ln \left(\frac{r}{a}\right)$

$q(r)=-q_{b} \frac{b}{r}$

sendo $u(r)$ o potencial em um ponto localizado em uma distância radial $r$ a partir do ponto $O$ e $q(r)$ o fluxo nesse mesmo ponto na direção radial. Assim, quando $r=b$ tem-se o potencial nos pontos localizados no exterior:

$u(r=b)=u(b)=u_{b}=u_{a}+q_{b} \ln \left(\frac{b}{a}\right)$

O fluxo nos pontos localizados no interior podem ser determinados conforme:

$q(r=a)=q(a)=q_{a}=-q_{b} \frac{b}{a}$

Adotando-se $a=1, b=2, u_{a}=100$ e $q_{b}=200$, das Equações (2.184) e (2.185) resulta que $u_{b}=377,258872$ e $q_{a}=-400,00$. Essas são as respostas analíticas de referência que são comparadas com os resultados numéricos obtidos via modelo utilizando o MEC. Nas análises feitas utilizaram-se diferentes quantidades de elementos bem como diferentes graus de aproximação dos elementos de contorno isoparamétricos. Do total de 12 discretizações adotadas para a utilização do modelo via MEC, três delas são ilustradas na Figura 2.20: 24 elementos lineares (a), 16 elementos quadráticos (b) e 8 elementos cúbicos (c). Os nós que seriam originalmente pertencentes a um mesmo elemento são descontinuados e assim informados nos dados de entrada. É importante destacar que o formato dos elementos representados na Figura 2.20, com exceção da discretização utilizando elementos lineares, são meramente ilustrativos, não correspondendo ao formato exato dos elementos de contorno.

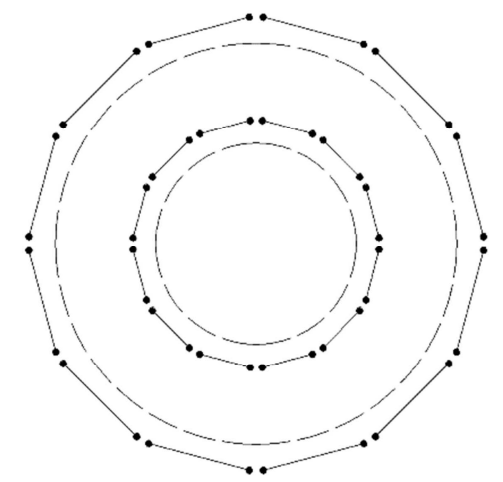

(a)

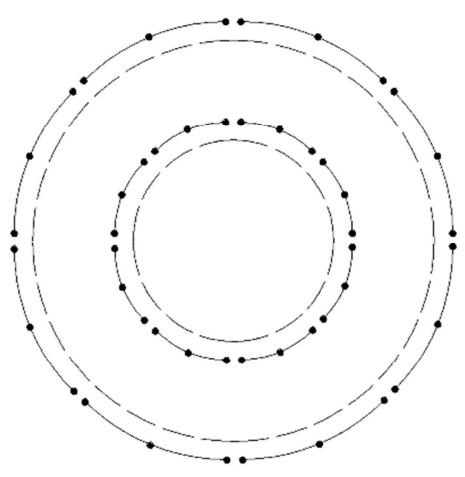

(b)

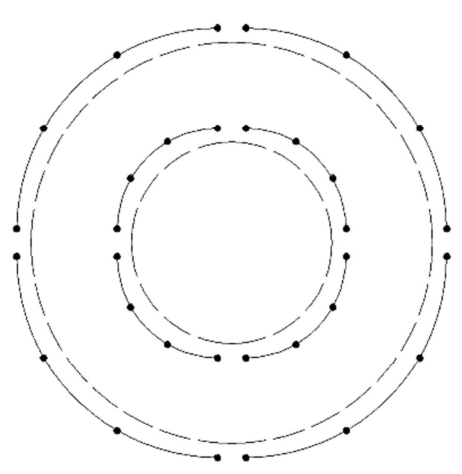

(c)

Figura 2.20 - Exemplo 2: discretizações adotadas 
O resumo dos dados de entrada e respostas de cada uma das 12 análises numéricas realizadas via MEC é apresentado na Tabela 2.1, incluindo o erro relativo entre a solução analítica e a resposta numérica. Apresenta-se na última coluna o tempo total de processamento de cada análise.

Tabela 2.1 - Exemplo 2: resumo das análises feitas

\begin{tabular}{|c|c|c|c|c|c|c|c|c|}
\hline $\begin{array}{l}\text { Aprox. do } \\
\text { elemento }\end{array}$ & $\begin{array}{l}\mathbf{N}^{\circ} \text { de } \\
\text { elem. }\end{array}$ & $\begin{array}{c}\mathrm{N}^{\mathrm{o}} \mathrm{de} \\
\text { pontos } \\
\text { de Gauss } \\
\text { por elem. }\end{array}$ & $\begin{array}{c}\mathbf{N}^{\circ} \text { de } \\
\text { graus de } \\
\text { liberdade }\end{array}$ & $q_{a}$ & $\begin{array}{c}\text { erro } \\
\text { relativo } \\
(\%)\end{array}$ & $u_{b}$ & $\begin{array}{c}\text { erro } \\
\text { relativo } \\
(\%)\end{array}$ & $\begin{array}{c}\text { tempo de } \\
\text { process. (seg) }\end{array}$ \\
\hline \multirow{4}{*}{ Linear } & 24 & \multirow{4}{*}{20} & 96 & $-401,2493$ & 0,3123 & 374,4235 & 0,7516 & 0,0468 \\
\hline & 32 & & 128 & $-400,6382$ & 0,1596 & 375,6933 & 0,4150 & 0,078 \\
\hline & 40 & & 160 & $-400,3848$ & 0,0962 & 376,2692 & 0,2623 & 0,0936 \\
\hline & 80 & & 320 & $-400,0850$ & 0,0212 & 377,0181 & 0,0638 & 0,3588 \\
\hline \multirow{4}{*}{ Quadrática } & 8 & \multirow{4}{*}{40} & 48 & $-395,3815$ & 1,1546 & 374,1910 & 0,8132 & 0,0156 \\
\hline & 16 & & 96 & $-399,2852$ & 0,1787 & 377,0363 & 0,0590 & 0,0312 \\
\hline & 24 & & 144 & $-399,7798$ & 0,0550 & 377,2133 & 0,0121 & 0,0468 \\
\hline & 32 & & 192 & $-399,9052$ & 0,0237 & 377,2443 & 0,0039 & 0,1092 \\
\hline \multirow{4}{*}{ Cúbica } & 8 & \multirow{4}{*}{80} & 64 & $-398,8416$ & 0,2896 & 378,1260 & 0,2298 & 0,0780 \\
\hline & 16 & & 128 & $-400,2927$ & 0,0732 & 377,3201 & 0,0162 & 0,2652 \\
\hline & 24 & & 192 & $-400,0931$ & 0,0233 & 377,2709 & 0,0032 & 0,5928 \\
\hline & 32 & & 256 & $-400,0405$ & 0,0101 & 377,2627 & 0,0010 & 1,0452 \\
\hline
\end{tabular}

As análises demonstraram que as soluções numéricas resultaram em uma boa concordância com a solução analítica. Destaque é dado ao baixo tempo de processamento requerido para todas as análises feitas, sendo essa uma das principais vantagens do método numérico adotado.

\subsubsection{Exemplo 3 - Regime transiente: domínio quadrado com fluxo unidimensional}

O terceiro exemplo trata da análise de um problema de potencial em regime transiente. $\mathrm{O}$ domínio é quadrado medindo $6 \times 6 \mathrm{~m}$. Como condições de contorno tem-se o valor do potencial nas faces $\mathrm{BC}$ e DA e o valor do fluxo nas faces $\mathrm{AB}$ e CD. Assume-se que o domínio possua potencial nulo no instante $t=0$ (no início da análise). O coeficiente de difusão adotado é $\kappa=1$. O contorno foi discretizado por meio de 24 elementos lineares isoparamétricos. A geometria, condições de contorno e a discretização adotada estão ilustrados na Figura 2.21.

Em tal problema o fluxo é unidimensional, ocorrendo apenas na direção horizontal e da esquerda para a direita, ou seja, da face DA para a face BC. A solução analítica para esse problema é apresentada por Boyce e Diprima (1979), tendo sido adotada como referência para comparação com a resposta numérica. Assume-se que o valor do potencial e do fluxo em cada ponto do domínio e do contorno permaneçam constantes em cada passo de tempo. Utilizam-se 10 pontos de Gauss por elemento para a integração numérica. 

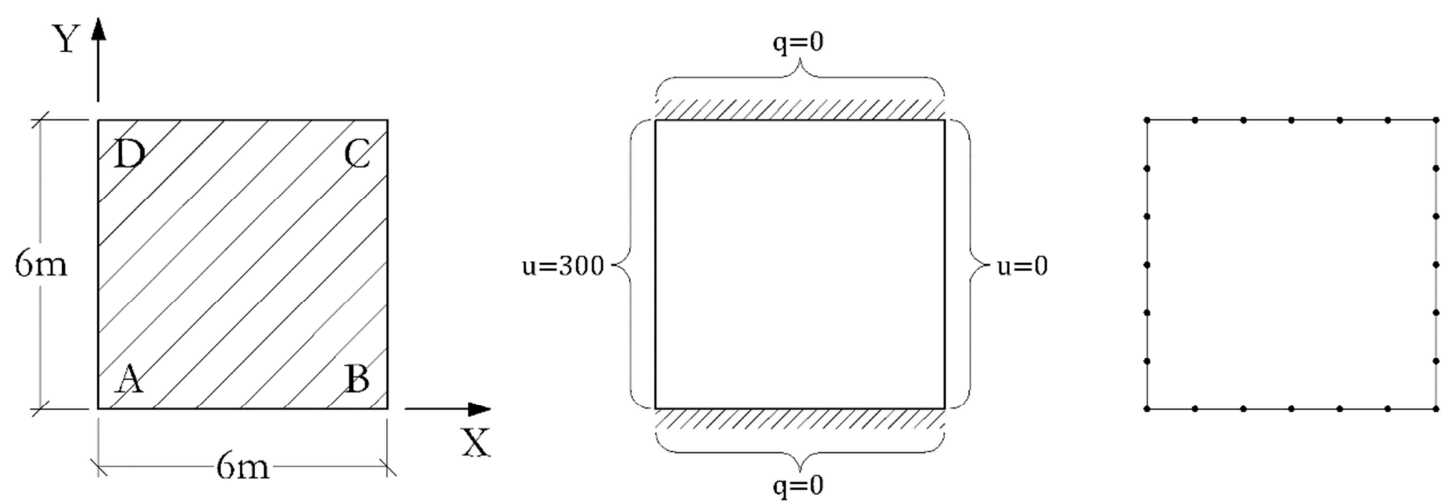

Figura 2.21 - Exemplo 3: geometria, condições de contorno e discretização do problema

Perfis da concentração (entendida aqui também como potencial) versus a coordenada $\mathrm{x}$ para 5 instantes de tempo distintos são traçados por meio da solução analítica e comparados com as respostas obtidas via MEC, conforme apresentado na Figura 2.22. Foram adotados 20 passos de tempo com $\Delta t=1 s$. Para a resposta numérica no domínio foram definidos 10 pontos internos espaçados de $0,5 \mathrm{~m}$ em x e numa altura de $\mathrm{y}=3 \mathrm{~m}$.

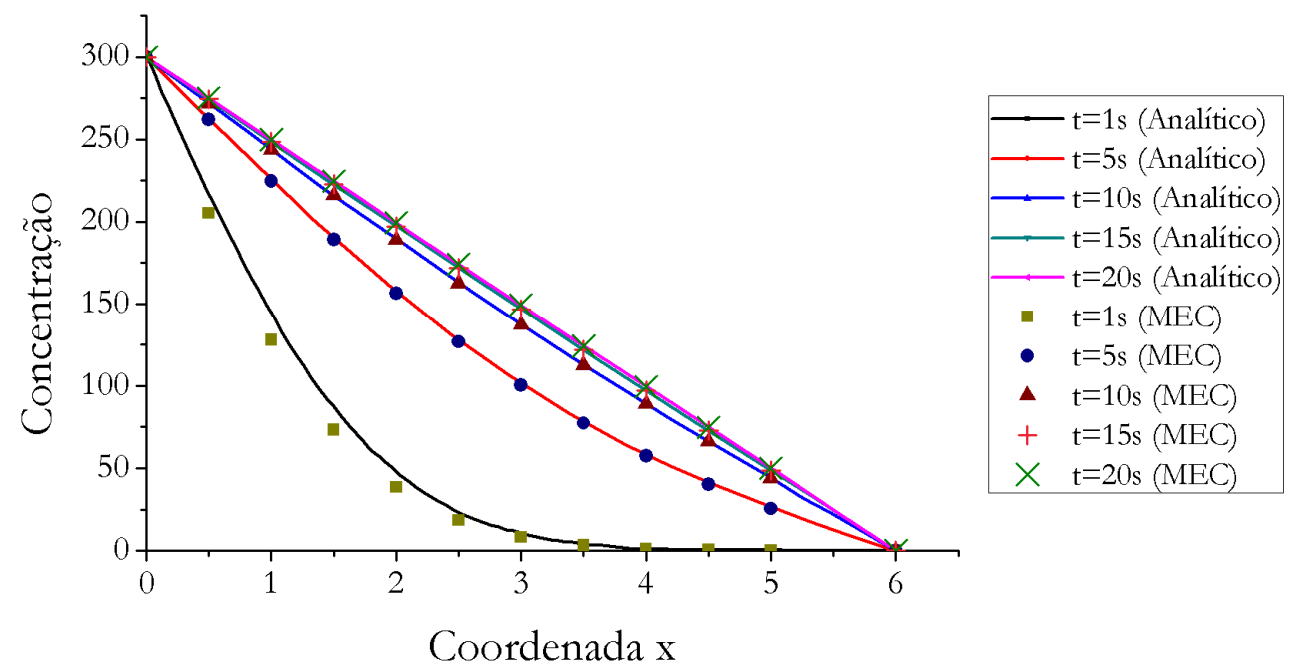

Figura 2.22 - Exemplo 3: Concentração vs. Coordenada x para $\Delta t=1 \mathrm{~s}$

Com o objetivo de verificar se o modelo numérico efetivamente representava um problema de fluxo unidimensional, os mesmos perfis foram traçados para outras alturas, diferentes de $y=3 \mathrm{~m}$. Tais perfis não foram aqui apresentados pois resultaram idênticos entre si, indicando de fato a representação de um problema com um fluxo unidimensional.

Constatou-se que com o avanço no tempo, a resposta numérica tendeu a apresentar uma melhor concordância com a resposta analítica. Contudo, a resposta numérica nos primeiros passos de tempo apresentou uma notável diferença com relação a solução analítica. Assim, uma nova análise foi feita empregando-se uma discretização no tempo com 20 passos e com $\Delta t=$ 
0,05s. Para a resposta numérica no domínio dessa outra análise foram definidos 12 pontos internos espaçados de $0,2 \mathrm{~m}$ em x e numa altura de $\mathrm{y}=3 \mathrm{~m}$. As respostas são apresentadas por meio dos perfis indicados na Figura 2.23 e Figura 2.24.

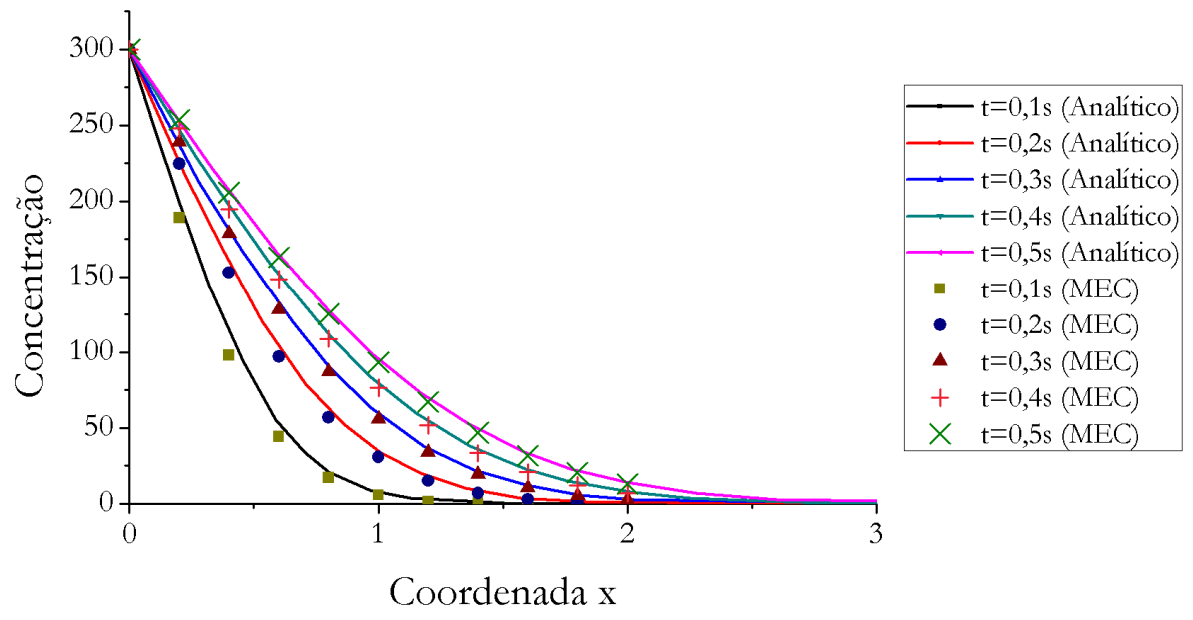

Figura 2.23 - Exemplo 3: Concentração vs. Coordenada x para $\Delta t=0,05 \mathrm{~s}$ de $t=0,1 \mathrm{~s}$ a $t=0,5 \mathrm{~s}$

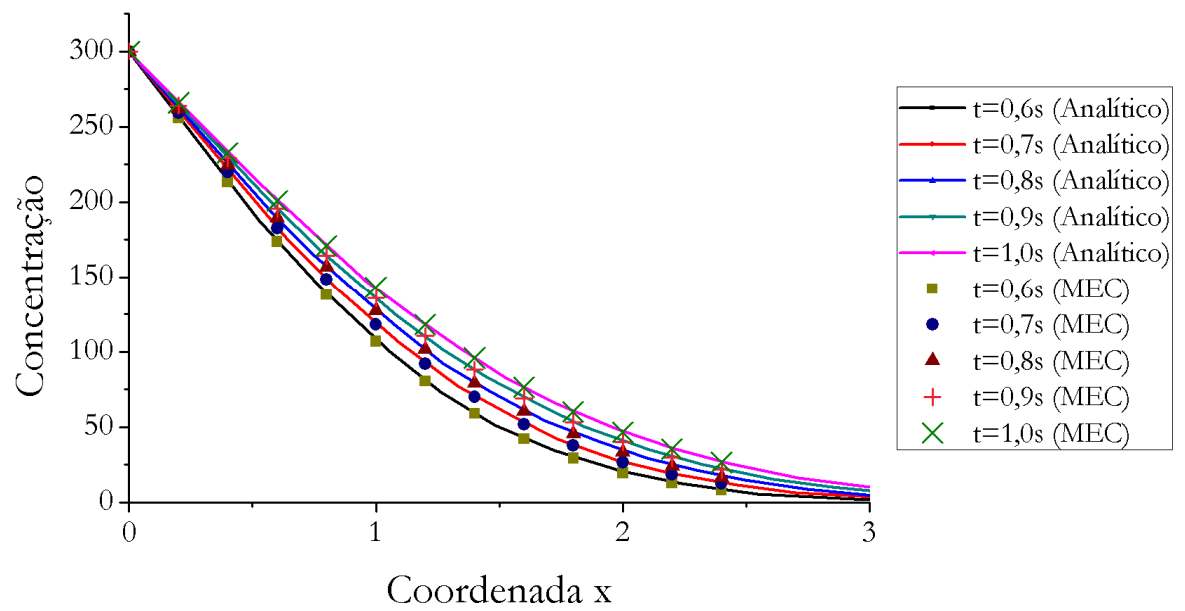

Figura 2.24 - Exemplo 3: Concentração vs. Coordenada x para $\Delta t=0,05 \mathrm{~s}$ de $t=0,6 \mathrm{~s}$ a $t=1,0 \mathrm{~s}$

Constatou-se novamente que, com o avanço no tempo, a resposta numérica tendeu a apresentar uma melhor concordância com a resposta analítica. Em $t=1 \mathrm{~s}$ a resposta numérica apresentou boa concordância com a resposta analítica, diferentemente do que foi observado para a análise com um maior valor de $\Delta t$. Contudo, novamente, a resposta numérica nos primeiros passos de tempo apresentou uma notável diferença com relação a solução analítica. Assim, entende-se que o processo de marcha no tempo para a solução numérica do problema requer certa quantidade de passos para estabilizar-se e assim descrever adequadamente o fenômeno.

Nesse problema, assim como em qualquer problema de potencial em regime transiente, caso as condições de contorno sejam mantidas constantes ao longo do tempo, a resposta tanto 
para pontos no domínio como no contorno tenderá àquela resultante para o mesmo problema em regime estacionário. Isso fica evidente conforme apresentado na Figura 2.22, onde, com o avanço do tempo, o potencial nos pontos ao longo do eixo $\mathrm{x}$ tendem a estabilizar-se em torno de uma reta definida pelos pontos (0;300) e (6;0). Por último destaca-se o baixo tempo de processamento computacional requerido: 0,690 segundos para a análise com 20 passos e com $\Delta t=1 \mathrm{~s}$ e de 1,99 segundos para a análise com 20 passos e com $\Delta t=0,05 s$.

\subsubsection{Exemplo 4 - Regime transiente: domínio quadrado com fluxo bidimensional}

No quarto exemplo considera-se um domínio de concreto quadrado $\mathrm{ABCD}$, conforme a Figura 2.25, medindo $150 \times 150 \mathrm{~mm}$. As faces $\mathrm{AB}$ e DA são expostas a um ambiente contendo cloretos com concentração de 1,0\% em relação à massa de cimento. Os outros dois lados são selados com uma resina de epóxi, de forma que nenhum íon de cloreto possa entrar por essas faces no concreto. Assume-se que o domínio possua concentração de cloretos nula no instante $t=0$ (no início da análise). O coeficiente de difusão adotado para o concreto é de $\kappa=31,536$ $\mathrm{mm}^{2} /$ ano. A formulação apresentada utilizando o MEC é aplicada ao problema para a obtenção da distribuição de cloretos ao longo da profundidade para tempos de exposição de 5, 10 e 20 anos. São utilizados 60 elementos isoparamétricos de aproximação linear para discretizar o contorno (15 elementos por lado). Todos os nós dos elementos são impostos como sendo descontínuos, o que totaliza 240 graus de liberdade para o problema. Utilizaram-se 3 discretizações no tempo: 4, 20 e 40 passos de tempo. A análise iniciou-se no tempo 0 e foi até 20 anos. Assume-se que o valor do potencial e do fluxo em cada ponto do domínio e do contorno permaneçam constantes em cada passo de tempo. Foram utilizados 10 pontos de Gauss por elemento para a integração numérica.

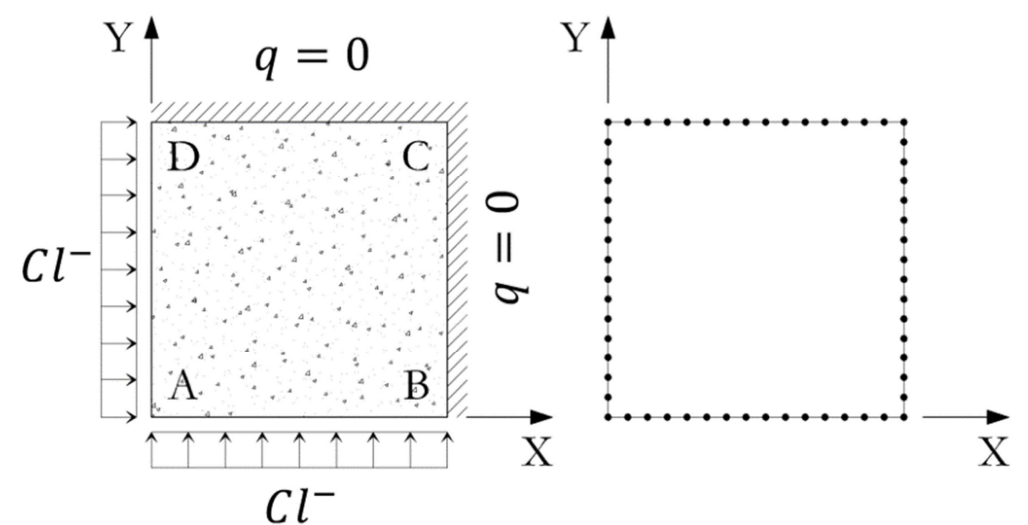

Figura 2.25 - Exemplo 4: geometria, condições de contorno e discretização espacial

Os resultados são comparados com aqueles obtidos por meio de uma solução analítica e com um modelo utilizando o Método dos Elementos Finitos (MEF) apresentados por Yang et al. 
(2013). As profundidades indicadas no perfil de cloretos referem-se a pontos localizados na bissetriz do ângulo no vértice A. A Tabela 2.2 e as Figuras (2.26), (2.27) e (2.28) apresentam os resultados obtidos.

Tabela 2.2 - Exemplo 4: resumo das análises feitas

\begin{tabular}{|c|c|c|c|c|c|c|c|}
\hline \multirow{3}{*}{ Método } & \multirow{3}{*}{$\begin{array}{c}\text { Tempo de } \\
\text { exposição (anos) }\end{array}$} & \multicolumn{6}{|c|}{$\begin{array}{c}\text { Concentração de cloretos (\% em relação a massa } \\
\text { de cimento) }\end{array}$} \\
\hline & & \multicolumn{6}{|c|}{ Profundidade (mm) } \\
\hline & & 10 & 20 & 30 & 40 & 50 & 60 \\
\hline Analítico & & 0,818 & 0,453 & 0,174 & 0,048 & 0,010 & 0,001 \\
\hline MEF & & 0,833 & 0,481 & 0,189 & 0,047 & 0,005 & 0,000 \\
\hline MEC - 4 passos & 5 & 0,742 & 0,368 & 0,131 & 0,034 & 0,007 & 0,001 \\
\hline MEC - 20 passos & & 0,806 & 0,434 & 0,162 & 0,043 & 0,008 & 0,001 \\
\hline MEC - 40 passos & & 0,813 & 0,443 & 0,167 & 0,045 & 0,009 & 0,001 \\
\hline Analítico & & 0,904 & 0,670 & 0,411 & 0,210 & 0,091 & 0,033 \\
\hline MEF & & 0,908 & 0,681 & 0,422 & 0,217 & 0,091 & 0,031 \\
\hline MEC - 4 passos & 10 & 0,878 & 0,624 & 0,367 & 0,180 & 0,075 & 0,027 \\
\hline MEC - 20 passos & & 0,901 & 0,663 & 0,401 & 0,203 & 0,086 & 0,031 \\
\hline MEC - 40 passos & & 0,903 & 0,667 & 0,406 & 0,206 & 0,089 & 0,032 \\
\hline Analítico & & 0,951 & 0,818 & 0,638 & 0,453 & 0,293 & 0,174 \\
\hline MEF & & 0,952 & 0,821 & 0,642 & 0,456 & 0,295 & 0,174 \\
\hline MEC - 4 passos & 20 & 0,944 & 0,802 & 0,616 & 0,429 & 0,273 & 0,159 \\
\hline MEC - 20 passos & & 0,950 & 0,815 & 0,634 & 0,448 & 0,289 & 0,171 \\
\hline MEC - 40 passos & & 0,950 & 0,817 & 0,636 & 0,450 & 0,291 & 0,172 \\
\hline
\end{tabular}

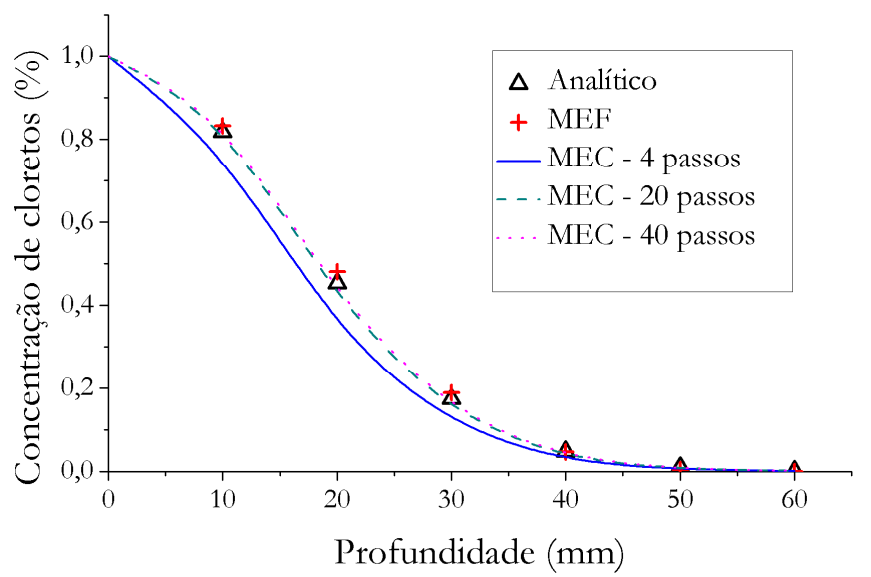

Figura 2.26 - Exemplo 4: perfil de concentração de cloretos: 5 anos de exposição 


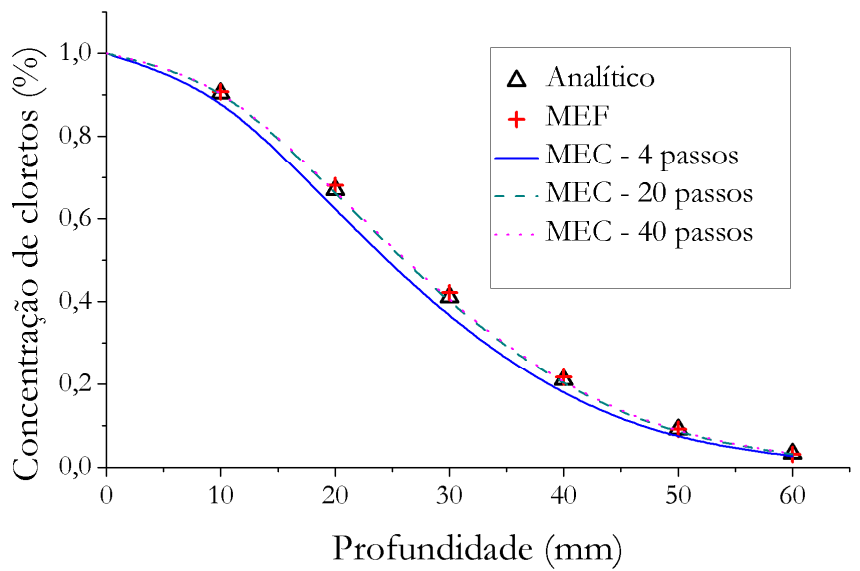

Figura 2.27 - Exemplo 4: perfil de concentração de cloretos: 10 anos de exposição

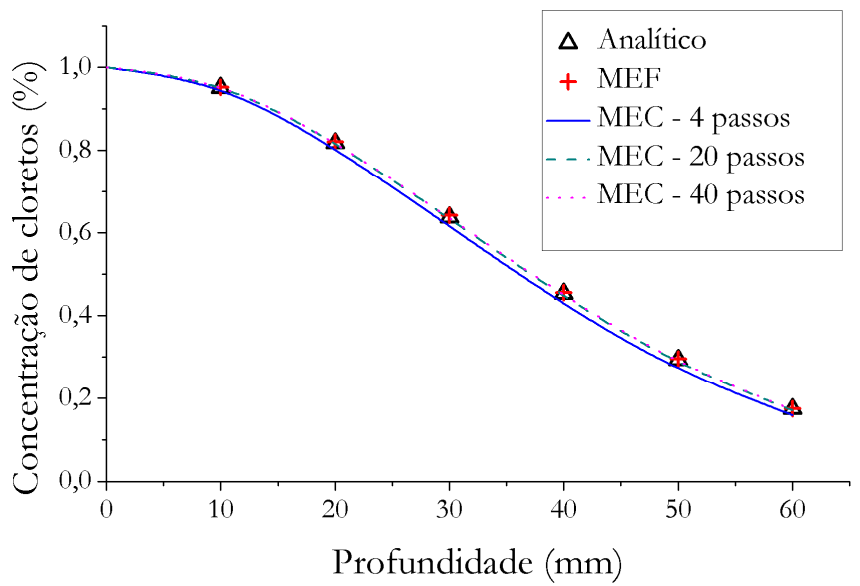

Figura 2.28 - Exemplo 4: perfil de concentração de cloretos: 20 anos de exposição

O modelo utilizando o MEC apresentou adequada concordância com a solução analítica, bem como com a solução via MEF. É evidente também que aplicando-se uma maior quantidade de passos de tempo a solução via MEC tende a ser mais próxima da solução analítica. Destaque deve ser dado a diferenças consideráveis entre a solução analítica e a solução via MEC associadas ao cálculo da concentração de cloretos nas primeiras idades (até 5 anos), conforme pode ser visto na Figura 2.26. No tempo igual a 5 anos o maior erro relativo constatado entre a solução analítica e a solução via MEC foi de 30\%, 15\% e 10\% para 4, 20 e 40 passos de tempo, respectivamente. Já para o tempo igual a 20 anos (final da análise) esse erro máximo constatado baixou para 6\%, $2 \%$ e $1 \%$. Assim sendo, é importante que a idade para a qual se deseja calcular o perfil de concentração tenha um número adequado de passos de tempo anteriores, com o objetivo de garantir melhor precisão do método.

No trabalho de Yang et al. (2013) não é especificado o tempo de processamento computacional para esse problema. Contudo, os autores discriminam o número de graus de liberdade da malha de elementos finitos adotada como sendo igual a 256. Em contrapartida, o 
número de graus de liberdade do modelo usando o MEC nesse exemplo foi de 240. Além disso, os autores comentam que o número de discretizações temporais adotadas para a modelagem usando o MEF é muito maior do que aquela necessária utilizando a modelagem via MEC, para um mesmo nível de precisão. Para a análise de 0 a 20 anos de difusão, o tempo de processamento para 4, 20 e 40 passos de tempo foi de 4,1496, 7,9092 e 14,0556 segundos, respectivamente.

Objetivando reduzir o tempo de processamento computacional, realizam-se novas análises para esse mesmo problema reduzindo-se o número de nós da discretização feita. Em tais análises foram considerados 60 nós contínuos (nós dos elementos entre os vértices $A, B, C$ e D) e 4 nós descontínuos (nós dos vértices $\mathrm{A}, \mathrm{B}, \mathrm{C}$ e D), totalizando 128 graus de liberdade. Os demais parâmetros foram adotados como sendo iguais ao que foi feito anteriormente. Verificou-se que as respostas obtidas tiveram valores praticamente iguais (diferença menor do que $0,1 \%$ ) àqueles obtidos anteriormente com o modelo usando o MEC com 240 graus de liberdade. Contudo, o tempo de processamento para 4, 20 e 40 passos de tempo foi de 3,7752, 5,9436 e 10,1088 segundos, respectivamente, o que corresponde a uma redução de $9 \%, 24 \%$ e $28 \%$.

\subsubsection{Exemplo 5 - Regime transiente: domínio circular}

No quinto exemplo considera-se um domínio circular com raio unitário. O contorno é submetido a um potencial externo em todos os seus pontos com valor igual a 50 do instante $t_{0}$ ao instante $t_{1}$ e varia bruscamente no instante $t_{1}$ para um valor de 100 e permanece assim até o tempo final da análise. A discretização adotada consistiu em 8 elementos isoparamétricos de aproximação quadrática. Assume-se que o domínio possua potencial nulo no instante $t=0$ (no início da análise). O coeficiente de difusão adotado é $\kappa=1$. A geometria, as condições de contorno e a discretização adotada estão ilustradas na Figura 2.29.

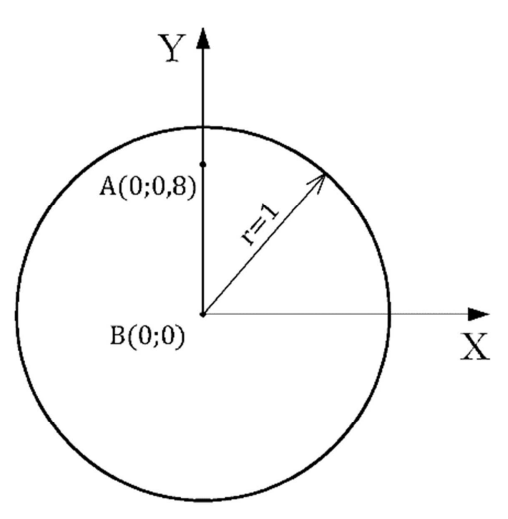

(a)

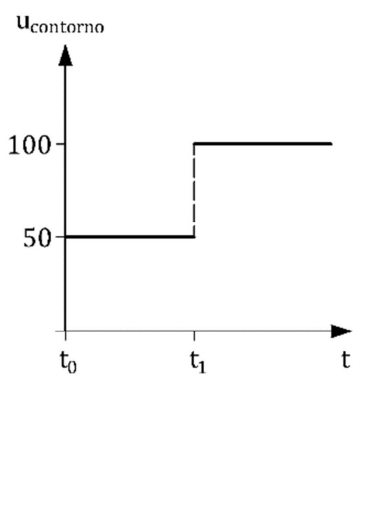

(b)

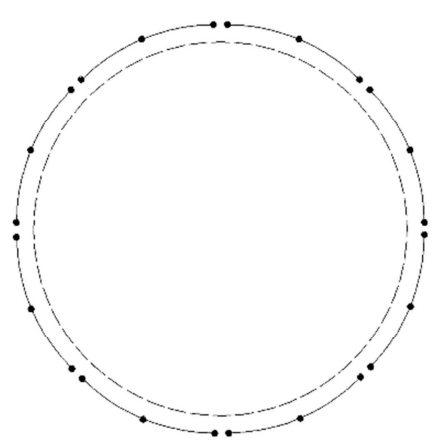

(c)

Figura 2.29 - Exemplo 5: geometria (a), condições de contorno (b) e discretização adotada (c) 
A solução analítica para esse problema é apresentada por Lachat e Combescure (1977), tendo sido adotada como referência para comparação com a resposta numérica. Para efeitos comparativos são escolhidos dois pontos internos, A e B, com coordenadas cartesianas iguais a $(0 ; 0,8)$ e $(0 ; 0)$, respectivamente. Assume-se que o valor do potencial e do fluxo em cada ponto do domínio e do contorno permaneçam constantes em cada passo de tempo. Foram realizadas três análises distintas variando-se o instante $t_{1}$ de mudança da condição de contorno. O resumo dos dados de entrada e tempos de processamento de cada uma das três análises numéricas realizadas via MEC é apresentado na Tabela 2.3.

Tabela 2.3 - Exemplo 5: resumo dos dados de entrada e tempos de processamento

\begin{tabular}{ccccccc}
\hline $\begin{array}{c}\mathrm{N}^{\circ} \mathrm{da} \\
\text { análise }\end{array}$ & $\begin{array}{c}t_{o} \\
(\mathrm{seg})\end{array}$ & $\begin{array}{c}t_{1} \\
(\mathrm{seg})\end{array}$ & $\begin{array}{c}\text { Tempo total da } \\
\text { análise }(\mathrm{seg})\end{array}$ & $\begin{array}{c}\mathrm{N}^{\mathrm{o}} \text { de passos } \\
\text { de tempo }\end{array}$ & $\begin{array}{c}\mathrm{N}^{\mathrm{o}} \text { de pontos de } \\
\text { Gauss por elem. }\end{array}$ & $\begin{array}{c}\text { Tempo de } \\
\text { process. (seg) }\end{array}$ \\
\hline \hline 1 & 0 & 0 & 1 & 40 & 10 & 0,9204 \\
2 & 0 & 0,5 & 1 & 40 & 10 & 0,9204 \\
3 & 0 & 1 & 2 & 80 & 20 & 3,49445 \\
\hline
\end{tabular}

Os perfis contendo o comparativo entre a solução analítica e a resposta numérica via MEC para as três análises feitas nos pontos internos A e B estão ilustrados nas Figuras (2.30), (2.31) e (2.32).

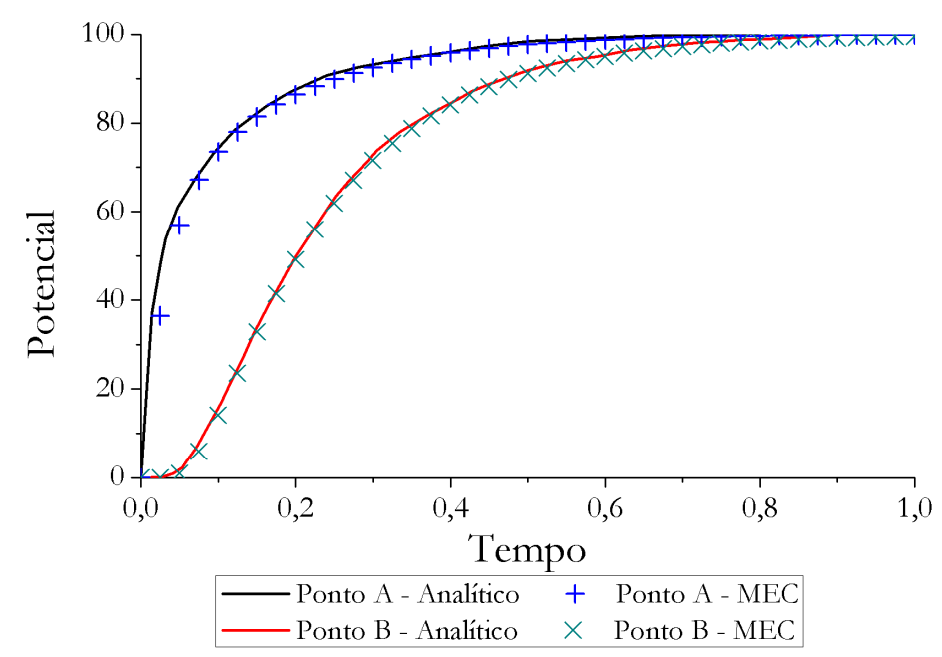

Figura 2.30 - Exemplo 5: Potencial x Tempo para a análise $1\left(t_{o}=t_{1}=0\right)$ 


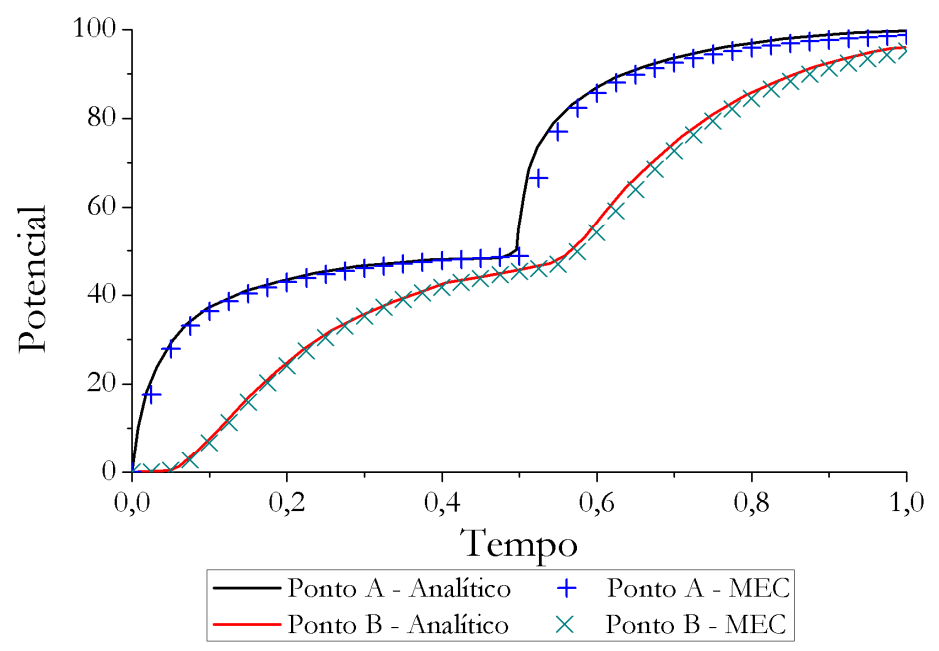

Figura 2.31 - Exemplo 5: Potencial x Tempo para a análise $2\left(t_{o}=0\right.$ e $\left.t_{1}=0,5 s\right)$

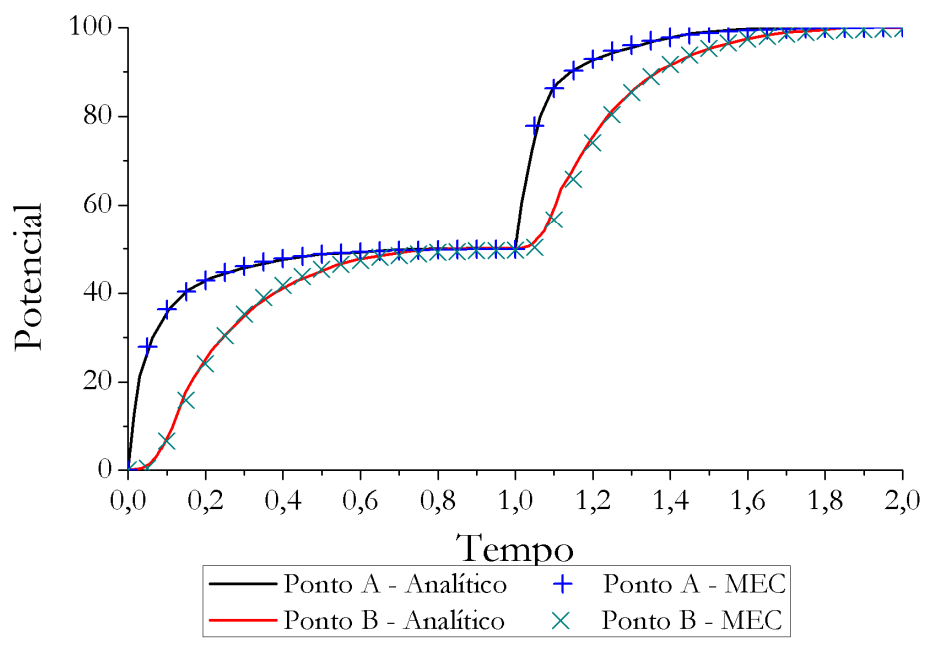

Figura 2.32 - Exemplo 5: Potencial x Tempo para a análise $3\left(t_{o}=0\right.$ e $\left.t_{1}=1,0 \mathrm{~s}\right)$

O modelo numérico utilizando o MEC apresentou adequada concordância com a solução analítica, demonstrando sua capacidade de aplicação em problemas de potencial em regime transiente com contorno circular e condições de contorno variáveis no tempo. Contudo, é possível notar que após a mudança nas condições de contorno a resposta numérica apresentou um pequeno distanciamento com relação à solução analítica, mas, com o avanço do tempo, a concordância entre as resposta foi obtida novamente. Aumentando-se a discretização temporal a concordância entre a resposta analítica e a resposta numérica seria melhorada. Em todas as análises é possível notar que a condição estacionária é mais rapidamente alcançada no ponto A do que no ponto B. Tal fato já era esperado, uma vez que o ponto B encontra-se a uma distância maior da fonte geradora de potencial do que o ponto A.

Foram realizadas posteriormente outras análises utilizando elementos com aproximação linear e cúbica, porém as respostas obtidas foram muito próximas àquelas aqui apresentadas 
utilizando elementos quadráticos. Assim sendo, propositalmente, tais resultados foram aqui omitidos.

\subsubsection{Exemplo 6 - Regime transiente: comparativo MEC e $2^{\mathrm{a}}$ lei de Fick em um domínio retangular}

No sexto exemplo é analisado um processo de difusão de íons cloreto em um domínio retangular de concreto medindo 180x90mm. No interior do domínio encontra-se uma barra de aço com diâmetro de $10 \mathrm{~mm}$ e com cobrimento de $40 \mathrm{~mm}$. A geometria do problema é ilustrada na Figura 2.33.

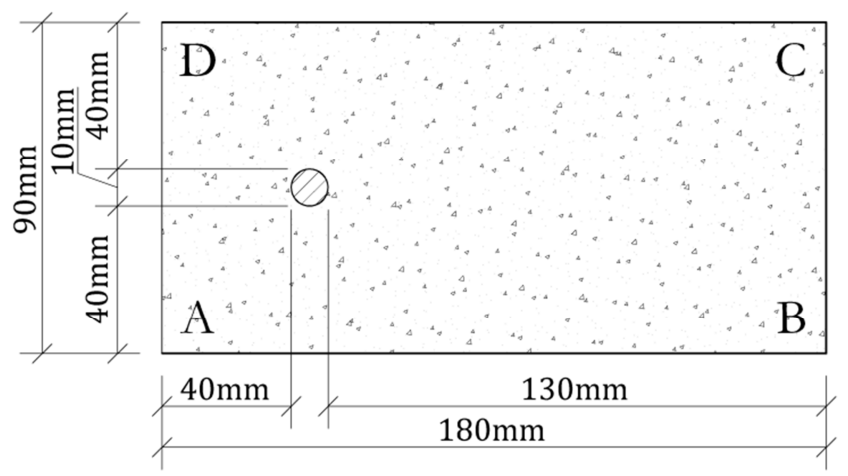

Figura 2.33 - Exemplo 6: geometria

Como solução de referência é utilizada a resposta fornecida pela segunda lei de Fick unidimensional. A segunda lei de difusão de Fick é aplicável a materiais homogêneos, isotrópicos e inertes e assume que as propriedade mecânicas no processo de difusão são iguais em todas as direções do espaço e se mantem constantes ao longo do tempo. Segundo as premissas teóricas da difusão de Fick, o transporte de cloretos no concreto, através de uma seção transversal unitária de material por unidade de tempo $(q)$, é proporcional ao gradiente de concentração de cloretos, medido na direção normal à seção transversal. Assim:

$q=-\kappa \frac{\partial C}{\partial x}$

O sinal negativo nessa equação surge devido ao fato da difusão de íons cloreto ocorrer na direção oposta ao aumento da concentração destes íons. A constante de proporcionalidade $\kappa$, apresentada na Equação (2.186), é o coeficiente de difusão de cloretos. Em geral, $\kappa$ não é uma constante, pois depende de vários parâmetros, como o tempo para o qual a difusão deve ser medida, localização do ponto na estrutura, composição do concreto, etc. Se o coeficiente de difusão é constante, a Equação (2.186) é usualmente denominada de primeira lei de difusão de Fick (lei esta aplicada para fenômenos de difusão em estado estacionário). Contudo, quando os íons cloreto difundem-se no concreto, ocorre a mudança na concentração de cloretos $C$, ao longo 
de um tempo $t$, em cada ponto $x$, do concreto, caracterizando um estado de difusão não estacionário. Por meio do princípio de balanço de massa, a segunda lei de Fick pode ser escrita como:

$\frac{\partial C}{\partial t}=\frac{\partial}{\partial x}\left(-\kappa \frac{\partial C}{\partial x}\right)$

Para a aplicação da segunda lei de difusão de Fick, como apresentado na Equação (2.187), em concretos expostos a cloretos durante um longo período de tempo, dever-se-ia conhecer a variação do coeficiente de difusão ao longo do tempo. Se apenas poucas observações existirem em um cenário específico, é possível estimar limites inferiores e superiores para a variação de $\kappa$ ao longo do tempo. Apesar dessa dependência, pode-se considerar um caso particular no qual o coeficiente de difusão é independente da localização $x$, do tempo $t$ e da concentração de cloretos $C$. Neste caso, a segunda lei de Fick pode ser assim reescrita:

$$
\frac{\partial C}{\partial t}=-\kappa_{0} \frac{\partial^{2} C}{\partial x^{2}}
$$

Nessa equação, $\kappa_{0}$ é o coeficiente de difusão constante no espaço e no tempo. A solução desta equação diferencial, para um domínio semi-infinito e com uma concentração de cloretos uniforme no contorno do domínio, é dada por:

$C(x, t)=C_{0} \operatorname{erfc}\left[\frac{x}{2 \sqrt{\kappa_{0} t}}\right]$

Assim sendo, a solução analítica descrita pela segunda lei de Fick é dada pela Equação (2.189). Nesta equação, $C_{0}$ é a concentração de íons cloreto no contorno do domínio (considerada constante ao longo do tempo) e erfc é a função matemática de valor complementar da função erro de Gauss dada por:

$$
\operatorname{erfc}(z)=1-\operatorname{erf}(z)=1-\frac{2}{\sqrt{\pi}} \int_{0}^{z} e^{-t^{2}} d t
$$

Existem na literatura diversas equações para a determinação do coeficiente de difusão. Por simplicidade utiliza-se a equação dada por Bentz et al. (1996) para a determinação de tal parâmetro nesse exemplo:

$$
\kappa_{0}=10^{-10+4,66 a / c} \mathrm{~cm}^{2} / \mathrm{s}
$$

Adotando-se a relação água/cimento $(a / c)$ igual a 0,5 , o coeficiente de difusão resulta igual a $2,1379 \cdot 10^{-8} \mathrm{~cm}^{2} / \mathrm{s}=67,4228 \mathrm{~mm}^{2} /$ ano.

Foram analisados quatro casos, variando-se de um para outro as condições de contorno, conforme mostrado na Figura 2.34. 


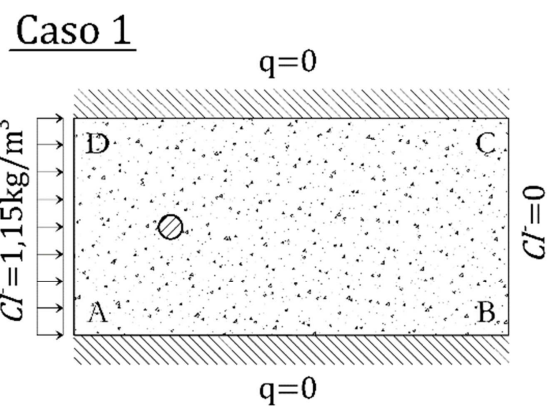

$\underline{\text { Caso } 3}$

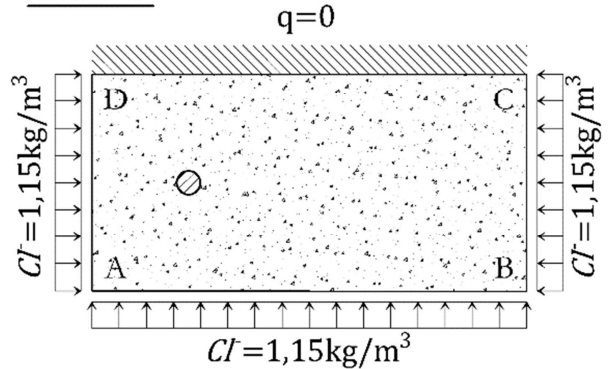

$\underline{\text { Caso } 2}$

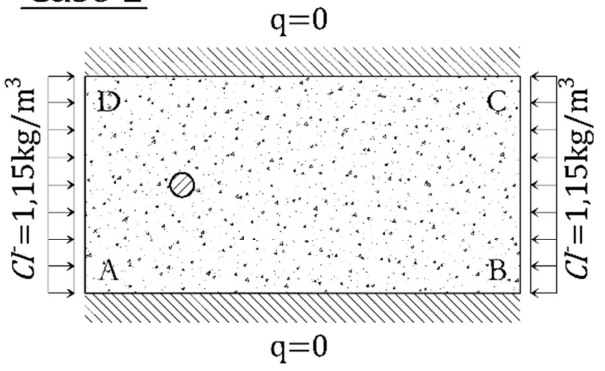

$\underline{\text { Caso } 4}$

$\mathrm{q}=0$

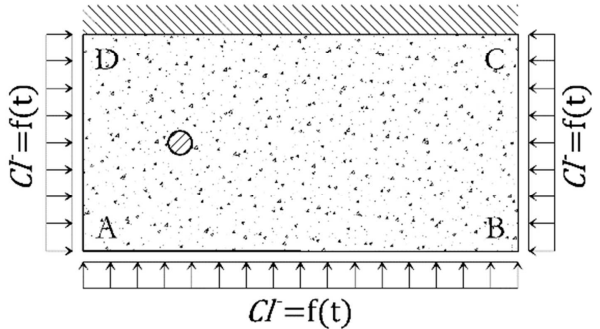

Figura 2.34 - Exemplo 6: condições de contorno para cada caso

No caso 1 tem-se um fluxo unidimensional de cloretos, indo da face da esquerda para a face da direita. No caso 2 tem-se um fluxo unidimensional, porém agora ele ocorrendo em dois sentidos (da face da esquerda para a face da direita e vice-versa). No caso 3 tem-se um estado de fluxo bidimensional, sendo que os cloretos adentram no domínio de concreto por três faces. Por último, tem-se o caso 4, sendo igual ao caso 3, porém o valor da concentração de cloretos no contorno é variável com o tempo, sendo esta variação ilustrada na Figura 2.35.

O valor da concentração superficial de cloretos foi adotado a partir do trabalho de McGee (1999) considerando-se um nível de agressividade moderado para uma estrutura situada entre 0,1 e 2,84 km distante da costa sem contato direto com a água do mar. Além disso, segundo Mehta e Monteiro (2008), para dosagens de concreto normalmente usadas na prática, o teor limite de cloretos para se iniciar a corrosão está entre 0,6 e $0,9 \mathrm{~kg} \mathrm{de} \mathrm{Cl}^{-}$por $\mathrm{m}^{3}$ de concreto.

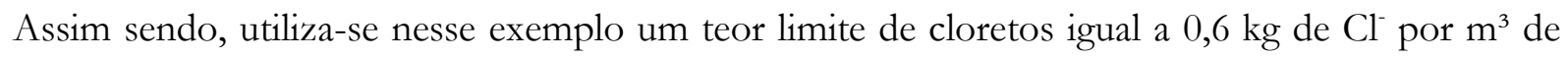
concreto.

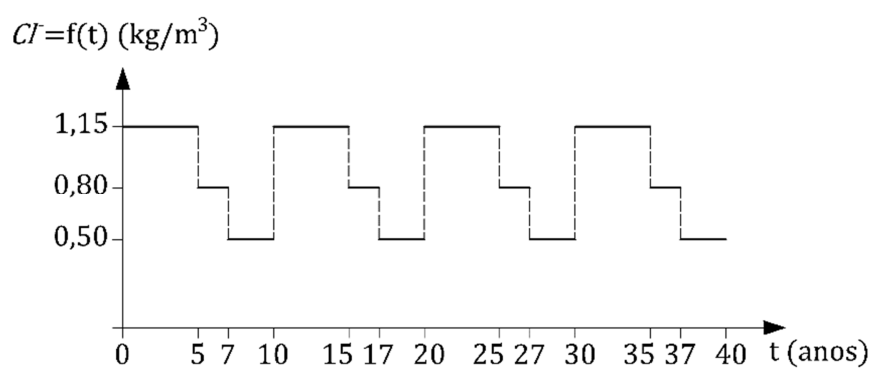

Figura 2.35 - Exemplo 6: variação da concentração de cloretos no contorno para o caso 4 
Para a solução numérica via MEC o contorno foi discretizado em 54 elementos isoparamétricos de aproximação linear com 10mm de comprimento cada um, totalizando 108 nós e 216 graus de liberdade. Utilizam-se 10 pontos de Gauss por elemento para a integração numérica. A discretização temporal foi feita em 40 passos de tempo partindo-se do ano 0 até o ano 40. Assume-se que o domínio possua potencial nulo no instante $t=0$ (no início da análise). Além disso, assume-se que o valor do potencial e do fluxo em cada ponto do domínio e do contorno permaneçam constantes em cada passo de tempo. O tempo de processamento computacional da análise foi de 16,0837 segundos.

Foram adotados pontos internos espaçados de $2 \mathrm{em} 2 \mathrm{~mm}$ ao longo de uma linha conectando os pontos médios dos lados $\mathrm{DA}$ e $\mathrm{BC}$, de forma que esta linha intercepte a armadura contida no interior do concreto. Assim sendo, o termo "profundidade" nesse exemplo é interpretado como sendo um ponto pertencente a essa linha, com uma coordenada definida a partir de uma origem localizada no ponto médio do lado DA. Os perfis de concentração de cloretos contendo o comparativo entre a solução analítica via lei de Fick e a resposta numérica via MEC para os quatro casos em função da profundidade estão ilustrados na Figura 2.36.
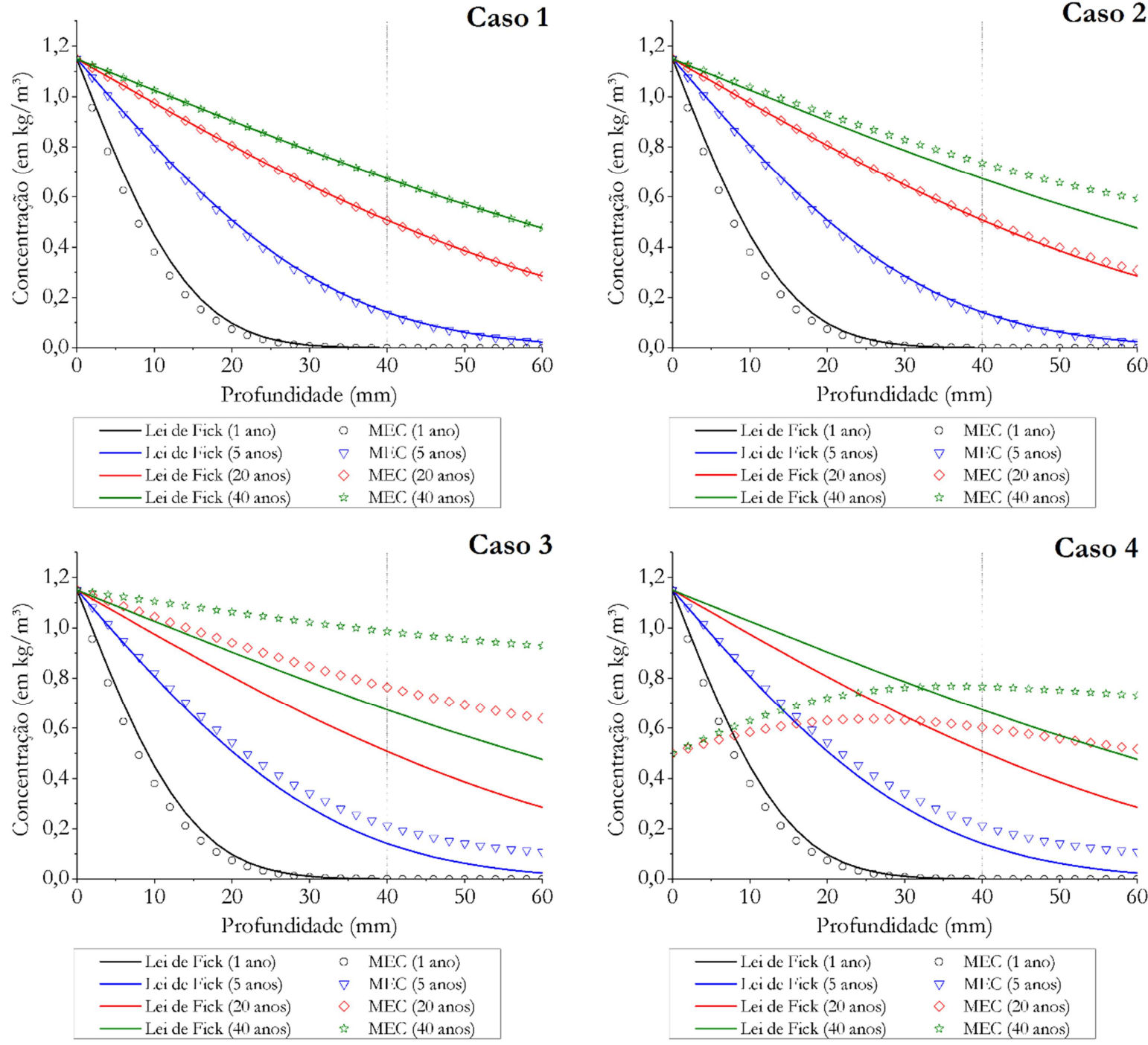

Figura 2.36 - Exemplo 6: Concentração X Profundidade 
Os perfis da concentração de cloretos contendo o comparativo entre a solução analítica via lei de Fick e a resposta numérica via MEC para os quatro casos numa profundidade fixa de $40 \mathrm{~mm}$, profundidade em que está localizada a armadura, estão ilustrados na Figura 2.37.
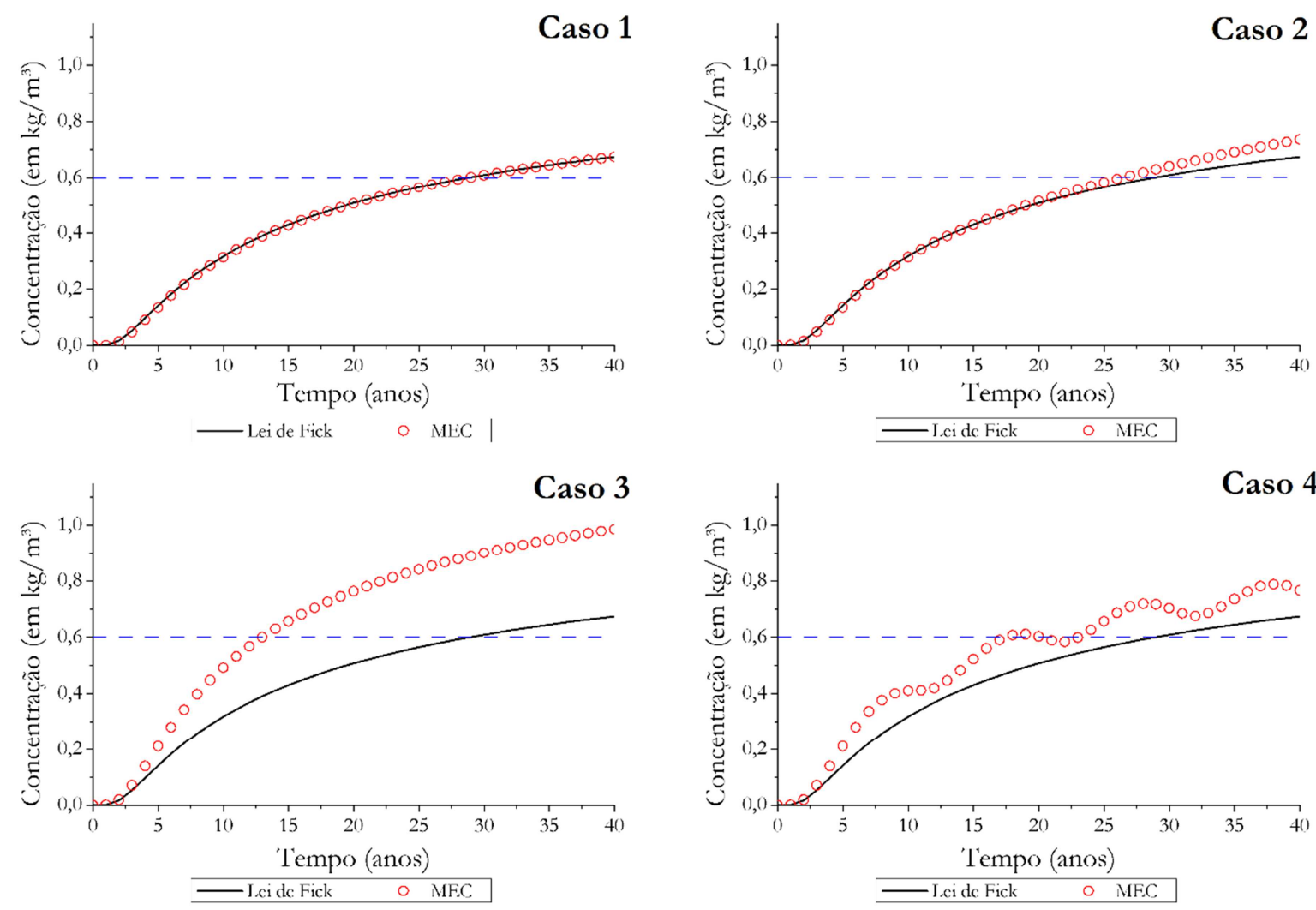

Figura 2.37 - Exemplo 6: Concentração X Tempo para uma profundidade fixa de $40 \mathrm{~mm}$

Para o caso 1 observa-se na Figura 2.36 e na Figura 2.37 que as respostas fornecidas pela lei de Fick e pelo MEC apresentam uma boa concordância, uma vez que tanto a solução analítica como a solução numérica retratam um fluxo unidimensional ocorrendo em apenas um sentido. Conforme já comentado anteriormente em outros exemplos de difusão em regime transiente, a resposta via MEC nos primeiros passos de tempo tende a apresentar uma pequena imprecisão, uma vez que o processo de marcha no tempo para a solução numérica do problema requer certa quantidade de passos para estabilizar-se. Comparando-se a solução via lei de Fick com a solução via MEC, as máximas diferenças de concentração encontradas para os pontos contidos ao longo da profundidade foram de 33,88\%, 5,31\%, 0,32\% e $0,07 \%$ para 1, 5, 20 e 40 anos, respectivamente. Ambas as soluções forneceram a mesma resposta para o tempo difusivo necessário para ocorrer a despassivação da armadura, sendo igual a 29 anos.

Para o caso 2, observa-se na Figura 2.36 que as respostas via MEC para 1 e 5 anos foram quase que idênticas em comparação ao caso 1. Para idades mais avançadas (20 e 40 anos) nota-se uma certa diferença entre os casos, uma vez que o processo difusivo que ocorre da face BC para o interior do domínio no caso 2 possui uma evolução tal que concentrações significativas de 
cloretos se somam àquelas provenientes do processo difusivo da face $\mathrm{DA}$ para o interior do domínio. Tal fato se torna ainda mais evidente para o caso 3, onde soma-se ainda um outro processo difusivo da face $\mathrm{AB}$ para o interior do domínio, acelerando a taxa de crescimento com o tempo da concentração de cloretos. O tempo difusivo necessário para ocorrer a despassivação da armadura no caso 2 foi de 26 anos e no caso 3 foi de 13 anos. Isso corresponde a tempos difusivos $10 \%$ e $55 \%$ menores com relação ao caso 1 .

Para o caso 4 arbitrou-se um conjunto de variações para as concentrações de cloretos nas superfícies de concreto com uma periodicidade de 10 anos. É possível observar o efeito de tal periodicidade na resposta ilustrada na Figura 2.37. Destaca-se que, para uma profundidade fixa igual a $40 \mathrm{~mm}$, a concentração de cloretos sofreu uma pequena redução nos tempos de 20 a 22 anos e 29 a 32 anos, conforme ilustrado na Figura 2.37. Essa redução é observada também em outros pontos. O tempo difusivo necessário para ocorrer a despassivação da armadura no caso 4 foi de 18 anos, correspondendo a um tempo 38\% menor com relação ao caso 1.

$\mathrm{Na}$ Figura 2.37, para todos os casos, observa-se que a taxa de crescimento com o tempo da concentração de cloretos (inclinação da curva) é maior nas primeiras idades e tende a reduzirse com o passar do tempo. Esse comportamento já era esperado, uma vez que nas primeiras idades o gradiente de concentração de cloretos é muito grande, ou seja, tem-se uma concentração de cloretos muito grande no exterior e nula no domínio. Com o avanço do processo difusivo, essa diferença tende a diminuir e estabilizar-se. Quando em um determinado ponto essa diferença é muito pequena entre dois passos de tempo consecutivos, atinge-se o regime estacionário de difusão. Claramente esse regime estacionário é atingido mais rapidamente em pontos internos localizados próximos a uma superfície com certa concentração de cloretos prescrita se essa concentração se manter constante no tempo.

Conforme já comentado anteriormente, a resposta fornecida pela segunda lei de Fick retrata um fluxo que ocorre em apenas uma direção, um sentido e onde as condições de contorno (concentrações de cloretos nas faces do concreto) se mantenham constantes ao longo do tempo. Assim sendo, para os casos 2 a 4 deste exemplo, a segunda lei de Fick perde a significância física, uma vez que não é capaz de tratar adequadamente o problema. Para se ter uma ideia, as máximas diferenças de concentração encontradas entre os dois modelos para os pontos contidos ao longo da profundidade foram de $9 \%, 50 \%$ e $49 \%$ para os casos 2, 3 e 4 respectivamente. Portanto, o uso de tal lei deve ser utilizado em casos particulares, tendo-se em mente suas limitações. Em contrapartida, o modelo numérico possui um grau de generalização maior, sendo assim aplicável a uma maior variedade de problemas. 


\section{CONFABLIDAD ESTRUTURAL}

\subsection{Considerações iniciais}

Estruturas e elementos estruturais são projetados, construídos e eventualmente submetidos à manutenção a fim de que cumpram um conjunto de requisitos. Dentre esses requisitos cita-se a capacidade resistente, o desempenho em serviço e a durabilidade. A avaliação do grau de segurança associado a cada requisito possibilita uma maior sensibilidade e entendimento do problema estudado. Nos últimos anos, a compreensão dos fenômenos envolvidos com as estruturas, bem como a capacidade de prever o comportamento estrutural ao longo da vida útil, evoluiu consideravelmente. Este avanço pode ser atribuído à realização de estudos experimentais e ao desenvolvimento de técnicas de modelagem, o que acabou sendo refletido em novas filosofias de projeto e normatização.

A atual metodologia de projeto adota uma abordagem semiprobabilística que, apesar de conseguir identificar os principais fenômenos envolvidos e prever o comportamento de estruturas usuais satisfatoriamente, não contempla procedimentos que tornem possível a quantificação do nível de segurança associado a determinada estrutura. Esta incapacidade é explicada pelo fato de que as incertezas, inerentes às variáveis envolvidas, não são explicitamente consideradas. Tais incertezas relacionadas ao comportamento estrutural podem ser adequadamente endereçadas à luz da teoria de confiabilidade.

\subsection{Classificação de incertezas}

Existem diversas formas de classificar as incertezas. Uma classificação generalista e bastante frequente divide as incertezas em dois grupos: incertezas intrínsecas e incertezas epistêmicas. As intrínsecas estão associadas à aleatoriedade presente na natureza dos processos e aos dados observados em fenômenos. Exemplos desse tipo de incerteza: variabilidade da intensidade de chuva, vento e neve, variabilidade da resistência dos materiais, intensidade de terremotos, etc. Já as incertezas epistêmicas são aquelas associadas as imperfeições existentes nos modelos idealizados do mundo real por causa de conhecimentos imperfeitos ou insuficientes da realidade. Fórmulas matemáticas, equações, algoritmos numéricos e programas de computador são alguns exemplos desse tipo de incerteza. $\mathrm{Na}$ teoria, a incerteza epistêmica pode ser reduzida ou até mesmo eliminada por meio de maiores estudos e coleta de dados do processo analisado. Por outro lado, a incerteza intrínseca não pode ser eliminada. 
Uma classificação de incertezas mais particularizada é dada por Melchers (1999). O autor classifica as incertezas em sete categorias:

- Incerteza fenomenológica: relacionada a fenômenos inimagináveis que possam afetar a estrutura. As falhas na ponte de Tacoma Narrows (1940) e do World Trade Center (2001) são exemplos típicos da ação desse tipo de incerteza;

- Incerteza de decisão: relacionada com a decisão de saber se um determinado evento ocorreu ou não;

- Incerteza de modelo: associada a forma de relação entre as variáveis básicas para representar as relações reais ou fenômenos de interesse;

- Incerteza de predição: relacionada a prever o estado/comportamento da estrutura em algum tempo no futuro;

- Incerteza física: relacionada a natureza inerentemente aleatória da variável. Exemplos: variação da resistência dos materiais, variação da intensidade da carga de vento, variação das dimensões geométricas de um elemento estrutural, etc.;

- Incerteza estatística: associada aos parâmetros estatísticos de uma variável que são determinados por meio de observações;

- Incerteza devido a fatores humanos: relacionada ao envolvimento humano nas fases de projeto, construção, utilização, etc., de uma estrutura e se subdivide em erros humanos e intervenção humana.

A seguir são apresentadas algumas definições e conceitos fundamentais para o entendimento da teoria de confiabilidade.

\subsection{Definições e conceitos}

Nesta seção são apresentados alguns conceitos e definições necessários para a introdução de conceitos próprios da teoria de confiabilidade estrutural. Maiores detalhes podem ser encontrados nos livros de Melchers (1999), Montgomery e Runger (1999), Nowak e Collins (2000), Papoulis (2002) e Ang e Tang (2007).

\subsubsection{Experimento, evento e espaço amostral}

Um "experimento", também chamado de "tentativa", é a execução de um teste que pode ser repetido infinitamente e que possui um conjunto definido de resultados possíveis. Experimentos que possuem somente um resultado possível são chamados de "experimentos determinísticos". Já os que possuem dois ou mais resultados possíveis são chamados de 
“experimentos aleatórios", sendo denominados simplesmente de "experimentos" neste trabalho. Alguns exemplos clássicos de experimentos são: lançamento de um dado, lançamento de uma moeda, escolha de uma carta de um baralho, sorteio de um número da loteria, etc. Exemplos de um experimento dentro da área de engenharia estrutural são: medida da resistência a compressão do concreto, medidas da base e altura de uma viga executada, medida da espessura de cobrimento de armaduras no concreto, etc.

Cada um dos possíveis resultados de um experimento é chamado de "ponto amostral". O conjunto de todos os possíveis resultados que um experimento possa apresentar é chamado de “espaço amostral”, denominado por $\Omega$. Um subconjunto de resultados do espaço amostral que respeitem a uma determinada regra é chamado de "evento". Um conjunto de eventos, relacionados por meio de operações específicas, é denominado de "espaço de eventos" ou "classe". Essas operações entre eventos são as de intersecção (ocorrência simultânea), união (ocorrência alternada), complementação (não ocorrência) e diferença.

Por exemplo, no experimento de lançar um dado com seis faces o espaço amostral seria $\Omega=\{1,2,3,4,5,6\}$, apresentando assim seis pontos amostrais. Um evento $A$ pode ser definido como a face superior do dado resultar em um valor menor ou igual a três após o lançamento, ou seja, $A=\{1,2,3\}$. Outro evento $B$ pode ser definido como a face superior do dado resultar igual a seis após o lançamento, ou seja, $B=\{6\}$. Um exemplo de classe pode ser o dado resultar no valor seis ou em um valor menor ou igual a três, ou seja, $A \cup B=\{1,2,3,6\}$.

Uma forma gráfica usual para a representação de um espaço amostral, pontos amostrais, eventos e classes são os diagramas de Venn, idealizados pelo matemático John Venn (1834-1923). No exemplo do lançamento do dado, o diagrama é mostrado na Figura (3.1):

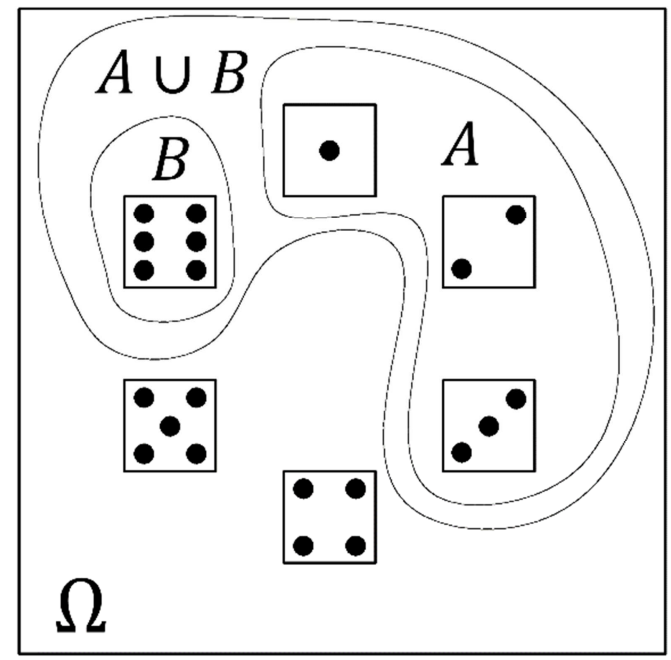

Figura 3.1 - Diagrama de Venn para o lançamento de um dado 


\subsubsection{Propensão e probabilidade}

Outros conceitos fundamentais são os de propensão e probabilidade. A propensão é uma medida da crença na ocorrência de um evento futuro. Já a probabilidade possui uma definição segundo as formas frequentista, clássica, Bayesiana (subjetiva) e axiomática. A definição matemática de probabilidade, dada de forma axiomática, é: “a probabilidade $P$ associada a um evento $A$ é um número associado a este evento que obedece aos seguintes postulados:"

1. $0 \leq P[A] \leq 1$, i.e., a probabilidade de ocorrência do evento $A$ é um número entre 0 e 1 ;

2. $P[\Omega]=1$, i.e., a probabilidade de um evento certo é igual a um;

3. $P[A \cup B]=P[A]+P[B]-P[A \cap B]$, i.e., a probabilidade de ocorrência de um evento formado pela união dos eventos $A$ e $B$ é a soma da probabilidade de ocorrência do evento $A$ com a probabilidade de ocorrência do evento $B$ subtraída da probabilidade de ocorrência simultânea (intersecção) dos eventos $A$ e $B$. Se os eventos $A$ e $B$ forem mutuamente exclusivos, a probabilidade de intersecção resulta nula.

\subsubsection{Variável aleatória e distribuições de probabilidade}

Uma variável aleatória é uma função que mapeia eventos do espaço amostral para o sistema numérico. Em outras palavras, uma variável aleatória é uma forma de atribuir valores numéricos a eventos. Nesse trabalho, variáveis aleatórias são representadas por letras maiúsculas e uma realização de uma variável aleatória por uma letra minúscula. Assim, o evento $\{X=x\}$ significa a variável aleatória $X$ assumir um valor igual a $x$. O mapeamento do espaço amostral para a reta dos números reais é ilustrado na Figura (3.2).

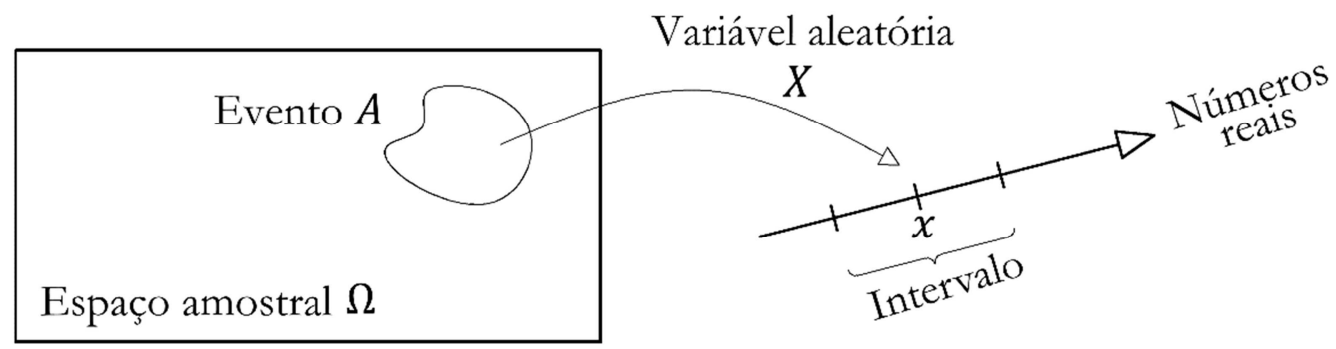

Figura 3.2 - Representação de uma variável aleatória

O espaço amostral pode ser composto por pontos amostrais discretos ou pontos amostrais contínuos, o que faz com que uma variável aleatória possa ser discreta, contínua ou mista. Os valores numéricos que uma variável aleatória pode assumir estão associados com medidas específicas de probabilidade. Tais medidas são especificadas de acordo com regras prescritas que são chamadas de distribuições de probabilidade. A distribuição de probabilidade de 
uma variável aleatória $X$ pode ser descrita por meio de sua função de distribuição acumulada $F_{X}$ (cumulative distribution function, $\mathrm{CDF}$, em inglês) da seguinte forma:

$F_{X}(x)=P[X \leq x]$

A Equação (3.1) é definida para qualquer $x$ entre $-\infty$ e $+\infty$, tanto para variáveis aleatórias discretas, contínuas ou mistas. Assim, a função de distribuição acumulada de $X$ corresponde a probabilidade de que a variável aleatória $X$ assuma um valor menor ou igual a $x$.

Quando a variável aleatória $X$ é discreta, a função de massa de probabilidade $p_{X}$ (probability mass function, PMF, em inglês) avalia a probabilidade de que $X$ assuma um valor identicamente igual a $x$ :

$p_{X}(x)=P[X=x]$

A função de distribuição acumulada de uma variável aleatória discreta pode ser escrita também como:

$F_{X}(x)=\sum_{\forall x_{i} \leq x} p_{X}\left(x_{i}\right)=\sum_{\forall x_{i} \leq x} P\left(X=x_{i}\right)$

Quando a variável aleatória $X$ é contínua, o cálculo da probabilidade de que $X$ assuma um valor identicamente igual a $x$ é nula. Para esse tipo de variável, as probabilidades de ocorrência de eventos devem ser definidas em intervalos específicos (contínuos). Tais probabilidades são dadas pelas funções de densidade de probabilidade $f_{X}$ (probability density function, PDF, em inglês) de forma que:

$P[a<X<b]=\int_{a}^{b} f_{X}(x) d x$

A função de distribuição acumulada de uma variável aleatória contínua relaciona-se com sua função de densidade de probabilidade da seguinte forma:

$F_{X}(x)=\int_{-\infty}^{x} f_{X}(x) d x \rightarrow f_{X}(x)=\frac{d F_{X}(x)}{d x}$

A Figura (3.3) ilustra as distribuições de probabilidade de variáveis aleatórias discretas, contínuas e mistas. 

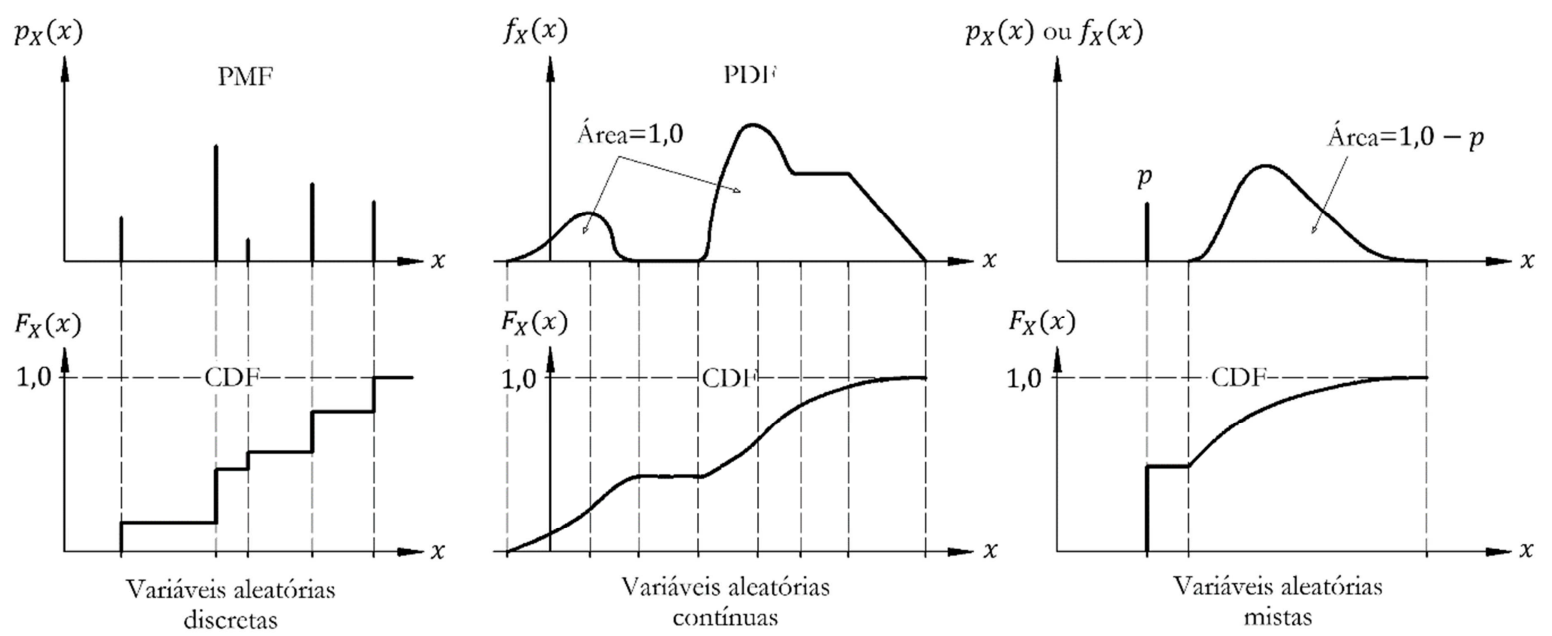

Figura 3.3 - Distribuições de probabilidade de variáveis aleatórias

\subsection{Estados limites}

Um sistema estrutural apresenta um comportamento satisfatório quando opera de forma a cumprir os requisitos e funções pelos quais o mesmo foi projetado. O não cumprimento de um requisito ou função de um sistema estrutural representa um estado indesejado. Cada distinta maneira que conduza a estrutura a um estado indesejado recebe o nome de "modo de falha". É importante destacar que "falha" nesse contexto não significa necessariamente o colapso estrutural. Por exemplo, uma estrutura projetada com certa limitação em seus deslocamentos pode ter atingido a falha caso apresente deslocamentos que ultrapassem esse limite preestabelecido.

A fronteira entre um comportamento estrutural desejado e um indesejado é chamada de estado limite. Os estados limites são normalmente definidos em normas de projeto. Por exemplo, para estruturas de concreto armado, a NBR 6118:2014 define dois tipos de estados limite: o estado limite último (ELU) e o estado limite de serviço (ELS). O ELU é caracterizado pela perda de equilíbrio da estrutura, colapso progressivo, esgotamento da capacidade resistente frente a ações normais, tangenciais, dinâmicas, efeitos de segunda ordem, entre outras. O ELS limita a abertura de fissuras, a magnitude das deformações, as vibrações, etc.

Os estados limite são matematicamente descritos pelas equações de estado limite, também conhecidas como equações de desempenho. Para cada estado limite da estrutura ou componente estrutural, uma equação de estado limite é escrita em função de um vetor $\boldsymbol{X}$ contendo as variáveis (determinísticas e/ou aleatórias) envolvidas naquele modo de falha:

$G(\boldsymbol{X})=G\left(X_{1}, X_{2}, \ldots, X_{n}\right)$

Uma falha (estado indesejado) é caracterizada quando a equação de estado limite $G(\boldsymbol{X})$ resultar em um valor negativo. Por outro lado, a segurança (estado desejado) é caracterizada 
quando a equação de estado limite $G(\boldsymbol{X})$ resultar em um valor positivo. Quando a equação de estado limite resultar igual a zero, tem-se a fronteira entre o domínio de falha e o de segurança. Tais domínios são representados por:

$\Omega_{f}=\{\boldsymbol{x} \mid G(X)<0\}$

$\Omega_{s}=\{\boldsymbol{x} \mid G(\boldsymbol{X})>0\}$

O domínio de falha $\Omega_{f}$ contém o conjunto de valores que as variáveis da equação de estado limite podem assumir que resultam em um estado indesejado para a estrutura. O domínio de segurança $\Omega_{s}$ contém o conjunto de valores complementares das variáveis do domínio de falha. Para duas variáveis aleatórias e uma equação de estado limite, tais domínios estão ilustrados na Figura (3.4):

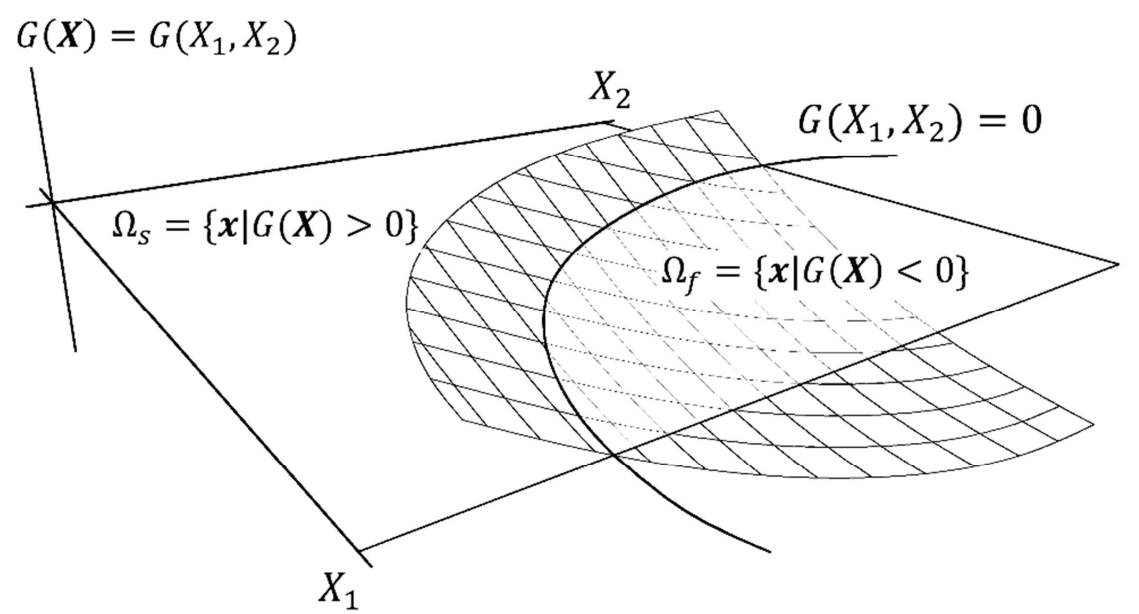

Figura 3.4 - Domínios de falha e segurança para um problema com duas variáveis aleatórias

\subsection{Probabilidade de falha}

A probabilidade de falha quantifica numericamente a propensão à violação de estados limites. A violação de um estado limite ocorre quando os valores assumidos pelas variáveis aleatórias encontram-se no domínio de falha. Em outras palavras, a violação de um estado limite ocorre quando a equação de estado limite resultar em um valor negativo. Assim, a probabilidade de falha é escrita como:

$P_{f}=P\left[\left\{\boldsymbol{x} \in \Omega_{f}\right\}\right]=P[G(\boldsymbol{X})<0]$

A Equação (3.8) pode ser reescrita, a partir das Equações (3.1) e (3.5), como:

$P_{f}=P[G(\boldsymbol{X})<0]=\int \ldots \int_{G(\boldsymbol{x})<0} f_{\boldsymbol{X}}(\boldsymbol{x}) d \boldsymbol{x}$

em que $f_{\boldsymbol{X}}(\boldsymbol{x})$ corresponde à função conjunta de densidade de probabilidade no espaço de projeto e a integral representa o conteúdo de probabilidades contido no domínio de falha. 
Caso as variáveis forem independentes entre si (assumidas como tal), a função conjunta de densidade de probabilidade $f_{\boldsymbol{X}}(\boldsymbol{x})$ é o resultado do produto das funções marginais de densidade de probabilidade $f_{X_{i}}\left(x_{i}\right)$ de cada variável $X_{i}$, conforme:

$f_{X}(\boldsymbol{x})=\prod_{i=1}^{n} f_{X_{i}}\left(x_{i}\right)=f_{X_{1}}\left(x_{1}\right) f_{X_{2}}\left(x_{2}\right) \ldots f_{X_{n}}\left(x_{n}\right)$

A integral múltipla apresentada na Equação (3.9) só é possível de ser calculada analiticamente para alguns casos especiais simplificados. Essa limitação ocorre, pois, normalmente:

- A função $f_{X}(\boldsymbol{x})$ não é conhecida ou é difícil de ser determinada;

- O domínio de falha, onde $G(\boldsymbol{X})<0$, é não linear;

- Ocorrem dificuldades no processo de integração.

Assim, o que se faz na prática é calcular essa integral múltipla por processos envolvendo técnicas de aproximação ou técnicas de simulação. Em geral, nas técnicas de transformação, a função $f_{\boldsymbol{X}}(\boldsymbol{x})$ é transformada em uma função de densidade de probabilidade multi-normal e o domínio de falha é aproximado para um formato conhecido e posicionado de tal forma a minimizar erros dessa aproximação. O FORM (acrônimo em inglês para First Order Reliability Method) e o SORM (acrônimo em inglês para Second Order Reliability Method) são clássicos exemplos desse conjunto de técnicas. Já nas técnicas de simulação, a integral múltipla é resolvida numericamente por meio de amostras pseudoaleatórias, geradas por meio de algoritmos específicos. O método de simulação de Monte Carlo (MSMC) é a mais conhecida das técnicas dessa categoria e é empregada no presente trabalho.

\subsection{O problema elementar da confiabilidade estrutural e o índice de confiabilidade}

Antes de propriamente apresentar a metodologia para resolver a integral múltipla apontada na seção anterior, é introduzido nessa seção o problema elementar (mais simples) dentro da confiabilidade estrutural para a apresentação de alguns conceitos como o índice de confiabilidade.

Considere uma equação de estado limite envolvendo apenas duas variáveis aleatórias, conforme:

$G(R, S)=R-S$

As variáveis aleatórias $R$ e $S$ são, respectivamente, a resistência e a solicitação atuantes em um elemento estrutural. Os valores numéricos de $R$ e $S$ podem ser obtidos por meio de equações 
analíticas, numéricas, estudos experimentais, etc. Para esta equação de estado limite, define-se que a falha do elemento estrutural ocorre quando a resistência for menor do que a solicitação atuante. Logo, a probabilidade de falha pode ser escrita de diversas formas, conforme:

$P_{f}=P[R<S]=P[R-S<0]=P\left[\frac{R}{S}<1\right]=P[(\ln R-\ln S)<0]$

ou, de maneira geral:

$P_{f}=P[G(R, S)<0]$

Com base na Equação (3.9), a Equação (3.13) pode ser reescrita realizando-se a integração da função conjunta de densidade de probabilidade, $f_{R S}(r, s)$ neste caso, sobre o domínio de falha. Assim:

$P_{f}=P[G(R, S)<0]=\iint_{\Omega_{f}} f_{R S}(r, s) d r d s$

Assumindo que as variáveis aleatórias $R$ e $S$ sejam estatisticamente independentes, da Equação (3.10) segue que:

$f_{R S}(r, s)=f_{R}(r) f_{S}(s)$

Substituindo a Equação (3.15) na Equação (3.14) tem-se:

$P_{f}=\int_{-\infty}^{+\infty} \int_{-\infty}^{s \geq r} f_{R}(r) f_{S}(s) d r d s$

As funções marginais de densidade de probabilidade $f_{R}(r)$ e $f_{S}(s)$, a função conjunta $f_{R S}(r, s)$, os domínios de falha e segurança e a equação de estado limite estão representadas na Figura (3.5):

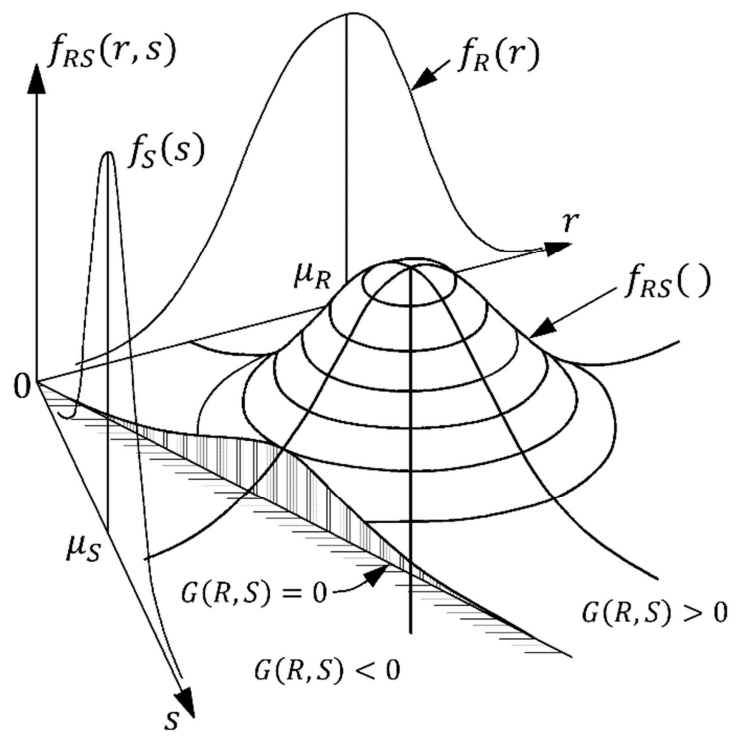

Figura 3.5 - Representação da função conjunta e funções marginais de densidade de probabilidade no problema elementar da confiabilidade estrutural. Adaptado de Melchers (1999) 
Sabe-se que, para qualquer variável aleatória $X$, a função de distribuição acumulada de probabilidades é dada por:

$F_{X}(x)=P[X \leq x]=\int_{-\infty}^{x} f_{X}(y) d y$

Sendo $x \geq y$, a Equação (3.15) pode ser reescrita, com base na Equação (3.17), conforme:

$P_{f}=\int_{-\infty}^{+\infty} F_{R}(x) f_{S}(x) d x$

A Equação (3.18) é conhecida como integral de convolução com relação a $x$, sendo a soma de todos os possíveis casos em que a resistência $R$ é menor do que a solicitação $S$. Contudo, o limite de integração inferior $(-\infty)$ da Equação (3.18) pode não ser um limite adequado, uma vez que valores negativos para a resistência não fazem sentido na prática. Assim, o limite inferior deveria ser estritamente igual a zero, apesar de que isto possa ser inconveniente e levemente impreciso se $R$ e $S$ forem ambas modeladas por distribuições sem limites inferiores, como a distribuição normal, por exemplo. Neste caso, truncar a distribuição normal de $R$ em zero seria uma possível solução.

Particularizando a Equação (3.11) para o caso das variáveis aleatórias $R$ e $S$ serem normais e não correlacionadas, é possível resolver o problema elementar da confiabilidade estrutural analiticamente. Como $R$ e $S$ possuem distribuições normais, $G$ será uma variável aleatória com distribuição normal por consequência e sua média $\mu_{G}$ e desvio padrão $\sigma_{G}$ podem ser calculados em função dos parâmetros estatísticos de $R$ e $S$, conforme:

$$
\begin{aligned}
& \mu_{G}=\mu_{R}-\mu_{S} \\
& \sigma_{G}=\sqrt{{\sigma_{R}}^{2}+\sigma_{S}^{2}}
\end{aligned}
$$

A variável aleatória $G$ pode ser transformada em uma variável aleatória normal padrão $Y_{G}$, ou seja, em uma variável com média zero e desvio padrão unitário, por meio da expressão:

$Y_{G}=\frac{G-\mu_{G}}{\sigma_{G}}$

Por meio desta transformação é possível avaliar a probabilidade de que $G$ seja menor do que zero, ou seja, a probabilidade de falha, conforme:

$P_{f}=P[G<0]=\Phi\left[-\frac{\mu_{G}}{\sigma_{G}}\right]$ 
em que $\Phi[$.$] é a integral da função de distribuição normal padrão acumulada padronizada \phi[$.$] .$ A razão entre a média e o desvio padrão de $G$ é definida como "índice de confiabilidade", sendo representado pela letra grega $\beta$ (beta), conforme:

$\beta=\frac{\mu_{G}}{\sigma_{G}}$

A função $\Phi[$.$] é então avaliada no ponto igual a -\beta$ conforme:

$P_{f}=\Phi[-\beta]=\int_{-\infty}^{-\beta} \phi(z) d z=\int_{-\infty}^{-\beta} \frac{1}{\sqrt{2 \pi}} \exp \left[-\frac{z^{2}}{2}\right] d z$

Logo, a probabilidade de falha e o índice de confiabilidade são relacionados por meio das expressões:

$P_{f}=\Phi[-\beta]$ ou $\beta=-\Phi^{-1}\left[P_{F}\right]$

A Equação (3.23) não possui solução analítica exata. Contudo, existem diversas expressões aproximadas para o cálculo desta integral, o que é muito vantajoso de um ponto de vista numérico.

$\mathrm{O}$ índice de confiabilidade $\beta$ pode ser interpretado geometricamente como sendo a mínima distância entre um ponto pertencente à equação de estado limite e a origem do espaço normal padrão não correlacionado. A área sobre a curva da função $\phi[$. $]$ entre $-\infty$ e $-\beta$ corresponde a probabilidade de falha $P_{f}$. Isto pode ser visualizado na Figura (3.6):

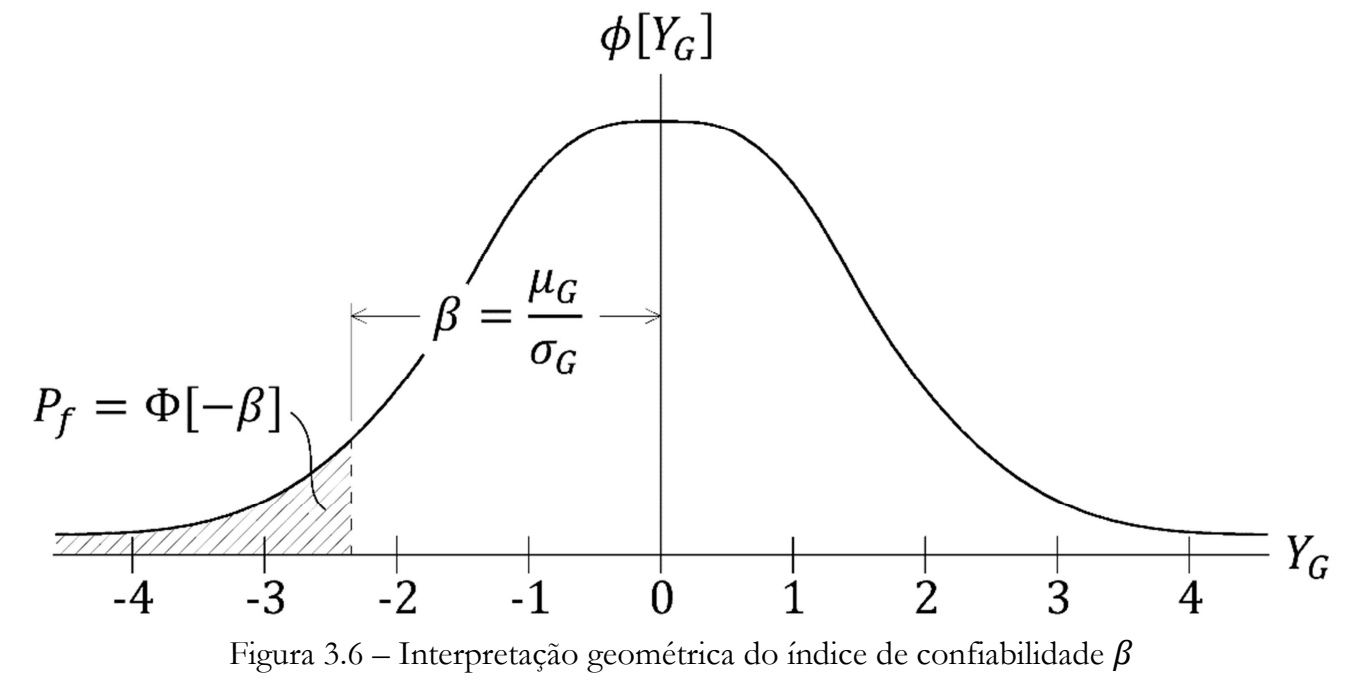

Alguns pares de valores do índice de confiabilidade e da probabilidade de falha estão representados na Figura (3.7). 


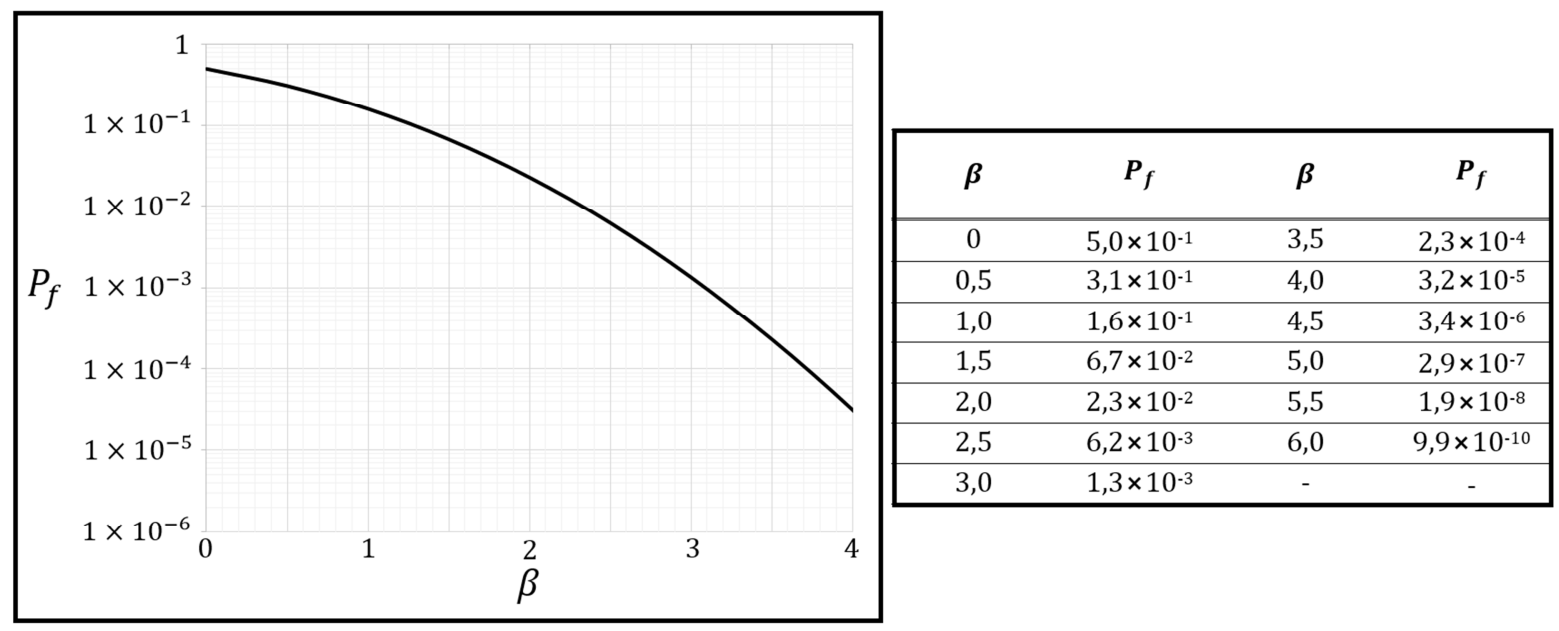

Figura 3.7 - Probabilidade de falha v.s. Índice de confiabilidade

Um importante conceito que surge dentro desse contexto é o de "ponto de projeto", normalmente designado por $y^{*}$. O ponto de projeto:

- É o ponto pertencente a equação de estado limite que corresponde a mínima distância entre essa equação e a origem do espaço normal padrão não correlacionado;

- É um ponto pertencente ao domínio de falha com o maior conteúdo de probabilidades associado devido a simetria radial do espaço normal padrão não correlacionado;

- É o ponto que conduz a um menor erro associado ao cálculo da $P_{f}$, caso aproximações (lineares, quadráticas, etc.) sejam feitas para representação da equação de estado limite.

É importante destacar que a metodologia até aqui apresentada para o cálculo de $P_{f}$ e $\beta$ é válida apenas para equações de estado limite lineares e variáveis aleatórias normais. Existem soluções invariáveis quanto ao formato da equação de estado limite e ao tipo de distribuição das variáveis aleatórias. Tais soluções são de extremo interesse para o escopo do presente trabalho, uma vez que a difusão de cloretos é um processo não linear e envolve variáveis aleatórias que seguem distribuições não normais.

\section{7 Índices de confiabilidade recomendados}

O índice de confiabilidade $\beta$ é um número que procura traduzir quantitativamente, com base num cálculo probabilístico, o grau de segurança associado a um determinado estado limite. Assim sendo, pode ser um parâmetro usado no controle da segurança e inclusive no processo de otimização de estruturas.

Até por volta dos anos 90, a maior parte das normas técnicas para o projeto de estruturas estavam baseadas em critérios de tensões admissíveis. As incertezas eram consideradas de forma muito simplificada por meio da utilização de um "fator de segurança central", também referido 
como "fator de segurança global". Tal fator visava criar uma margem de segurança entre a tensão atuante no material e sua tensão resistente. Além disso, a maior parte das tensões eram calculadas considerando-se um regime elástico linear de comportamento dos materiais.

Gradativamente, o critério das tensões admissíveis foi substituído pelo critério dos estados limite, sendo este o formato das normas atuais. Nesta filosofia de projeto são utilizados "coeficientes parciais de segurança” prescritos. Em um primeiro momento, estes coeficientes descritos nas normas foram obtidos a partir de análises de calibração que representassem um nível de segurança compatível com as normas mais antigas. O nível de segurança foi determinado por meio de avaliações de $\beta$ à luz da teoria de confiabilidade, considerando variáveis aleatórias com distribuição normal. Assim sendo, os coeficientes parciais de segurança estão fundamentados em análises de confiabilidade. É por este motivo que o formato das normas atuais é considerado semiprobabilístico, i.e., considera indiretamente as incertezas das variáveis envolvidas.

Com o objetivo de investigar e divulgar conhecimentos a respeito da gestão baseada no ciclo de vida da segurança, confiabilidade, risco, robustez, durabilidade, resiliência e sustentabilidade no âmbito da engenharia estrutural, em 1971 foi fundado o Joint Committee on Structural Safety (JCSS). Atualmente, este comitê é formado por seis importantes associações mundiais: CIB (International Council for Research and Innovation in Building and Construction), ECCS (European Convention for Constructional Steelwork), fib (International Federation for Structural Concrete), IABSE (International Association for Bridge and Structural Engineering), RILEM (Reunion internationale des Laboratoires et Experts des Materiaux) e o IASS (International Association for Shell and Spatial Structures).

Em 2001, este comitê publicou um documento chamado Probabilistic Model Code (modelo de norma probabilística), apresentando recomendações para a formulação e revisão de normas técnicas de projeto de estruturas. Uma das principais informações que consta neste documento é a recomendação de índices de confiabilidade mínimos para projetos estruturais, também chamados de "índices de confiabilidade alvo" $\beta_{T}$. Estes índices e suas correspondentes probabilidades de falha para ELU e ELS irreversíveis estão apresentados na Tabela $(3.1)^{2}$, para um período de retorno de um ano.

\footnotetext{
${ }^{2}$ Os valores de $\beta_{T}$ reportados na literatura para ELS são generalistas. Estudos que objetivem recomendar $\beta_{T}$ para estados limites mais específicos, como o estado limite de iniciação da corrosão, se fazem necessários.
} 
Tabela 3.1 - Índices de confiabilidade alvo $\boldsymbol{\beta}_{\boldsymbol{T}}$ recomendados pelo JCSS (2001) e respectivas probabilidades de falha para um período de retorno de um ano

\begin{tabular}{ccccc}
\hline $\begin{array}{c}\text { Custo relativo das } \\
\text { medidas de segurança }\end{array}$ & \multicolumn{2}{c}{ ELU - Consequências de falha } & ELS irreversível \\
Pequenas & Moderadas & Grandes & Índice alvo \\
\hline \multirow{2}{*}{ Alto } & $\beta_{T}=3,1$ & $\beta_{T}=3,3$ & $\beta_{T}=3,7$ & $\beta_{T}=1,3$ \\
& $\left(P_{f} \approx 10^{-3}\right)$ & $\left(P_{f} \approx 5 \cdot 10^{-4}\right)$ & $\left(P_{f} \approx 10^{-4}\right)$ & $\left(P_{f} \approx 10^{-1}\right)$ \\
\hline \multirow{2}{*}{ Normal } & $\beta_{T}=3,7$ & $\beta_{T}=4,2$ & $\beta_{T}=4,4$ & $\beta_{T}=1,7$ \\
& $\left(P_{f}=10^{-4}\right)$ & $\left(P_{f} \approx 10^{-5}\right)$ & $\left(P_{f} \approx 5 \cdot 10^{-6}\right)$ & $\left(P_{f} \approx 5 \cdot 10^{-2}\right)$ \\
\hline \multirow{2}{*}{ Baixo } & $\beta_{T}=4,2$ & $\beta_{T}=4,4$ & $\beta_{T}=4,7$ & $\beta_{T}=2,3$ \\
& $\left(P_{f} \approx 10^{-5}\right)$ & $\left(P_{f} \approx 5 \cdot 10^{-6}\right)$ & $\left(P_{f} \approx 10^{-6}\right)$ & $\left(P_{f} \approx 10^{-2}\right)$ \\
\hline
\end{tabular}

O nível de gravidade das consequências de falha (pequenas, moderadas e grandes) é baseado em um coeficiente $\rho$ que corresponde à razão entre custos totais (custos de construção, manutenção, reparo e custos diretos de falha) e custos de construção, conforme:

- Consequências pequenas $(\rho<2)$ : o risco de perda de vidas e as consequências econômicas são pequenas ou negligenciáveis (por exemplo: silos e estruturas agrícolas);

- Consequências moderadas $(2<\rho<5)$ : o risco de perda de vidas dada uma falha é médio e as consequências econômicas são consideráveis (por exemplo: construções residenciais, comerciais ou industriais);

- Consequências grandes $(5<\rho<10)$ : o risco de perda de vidas dada uma falha é alto e as consequências econômicas são significantes (por exemplo: pontes, teatros, hospitais, edifícios altos).

Se $\rho$ resultar maior do que 10, as consequências de falha são extremas e deve-se realizar uma análise de custo-benefício completa. Além disso, deve-se considerar a localização da estrutura na determinação do nível de gravidade das consequências de falha.

A norma europeia EN 1990:2002 é um exemplo que reflete o efeito do documento publicado pelo JCSS em 2001. Nessa norma consta uma tabela indicando valores mínimos para o índice de confiabilidade alvo $\beta_{T}$ para três classes de risco, sendo considerado o ELU e com períodos de retorno de 1 e 50 anos, conforme a Tabela (3.2). 
Tabela 3.2 - Índices de confiabilidade alvo $\boldsymbol{\beta}_{\boldsymbol{T}}$ recomendados pela norma EN 1990:2002 e respectivas probabilidades de falha para períodos de retorno de 1 e 50 anos

\begin{tabular}{|c|c|c|c|}
\hline \multirow[b]{2}{*}{ Classe de risco } & \multirow[b]{2}{*}{ Consequências de falha } & \multicolumn{2}{|c|}{ Valor mínimo de $\beta_{T} /$ Probabilidade de falha $P_{f}$} \\
\hline & & $\begin{array}{c}\text { Período de retorno } \\
\text { de } 1 \text { ano }\end{array}$ & $\begin{array}{c}\text { Período de retorno } \\
\text { de } 50 \text { anos }\end{array}$ \\
\hline Classe 1 & Pequenas & $\begin{array}{c}\beta_{T}=4,2 \\
\left(P_{f} \approx 10^{-5}\right)\end{array}$ & $\begin{array}{c}\beta_{T}=3,3 \\
\left(P_{f} \approx 5 \cdot 10^{-4}\right)\end{array}$ \\
\hline Classe 2 & Moderadas & $\begin{array}{c}\beta_{T}=4,7 \\
\left(P_{f} \approx 10^{-6}\right)\end{array}$ & $\begin{array}{c}\beta_{T}=3,8 \\
\left(P_{f} \approx 5 \cdot 10^{-5}\right)\end{array}$ \\
\hline Classe 3 & Grandes & $\begin{array}{c}\beta_{T}=5,2 \\
\left(P_{f} \approx 10^{-7}\right)\end{array}$ & $\begin{array}{c}\beta_{T}=4,3 \\
\left(P_{f} \approx 10^{-5}\right)\end{array}$ \\
\hline
\end{tabular}

É interessante notar nesta tabela que o índice de confiabilidade mínimo $\beta_{T}$ recomendado decai com o avanço do tempo. Isto ocorre pois, em geral, as variáveis aleatórias são dependentes do tempo, interferindo assim no valor da probabilidade de falha ao longo do tempo também. Segundo Holický et al. (2005) é possível estimar a probabilidade de falha de projeto $P_{f, t}$ em um dado tempo $t$ conforme:

$P_{f, t}=1-\left(1-P_{f, 0}\right)^{t}$

em que $P_{f, 0}$ é a probabilidade de falha de projeto inicial, quando $t=0$. Se os modos de falha forem considerados independentes, o índice de confiabilidade de projeto $\beta_{t}$, num tempo $t$, pode ser relacionado ao índice de confiabilidade de projeto inicial $\beta_{0}$ conforme:

$\Phi\left[\beta_{t}\right]=\left\{\Phi\left[\beta_{0}\right]\right\}^{t} \rightarrow \beta_{t}=\Phi^{-1}\left\{\Phi\left[\beta_{0}\right]\right\}^{t}$

A Tabela (3.8) ilustra a variação de $\beta_{t}$ conforme $\beta_{0}$ para vários tempos $t$. É interessante notar que os valores na tabela abaixo são muito próximos daqueles sugeridos pela norma EM 1990:2002.

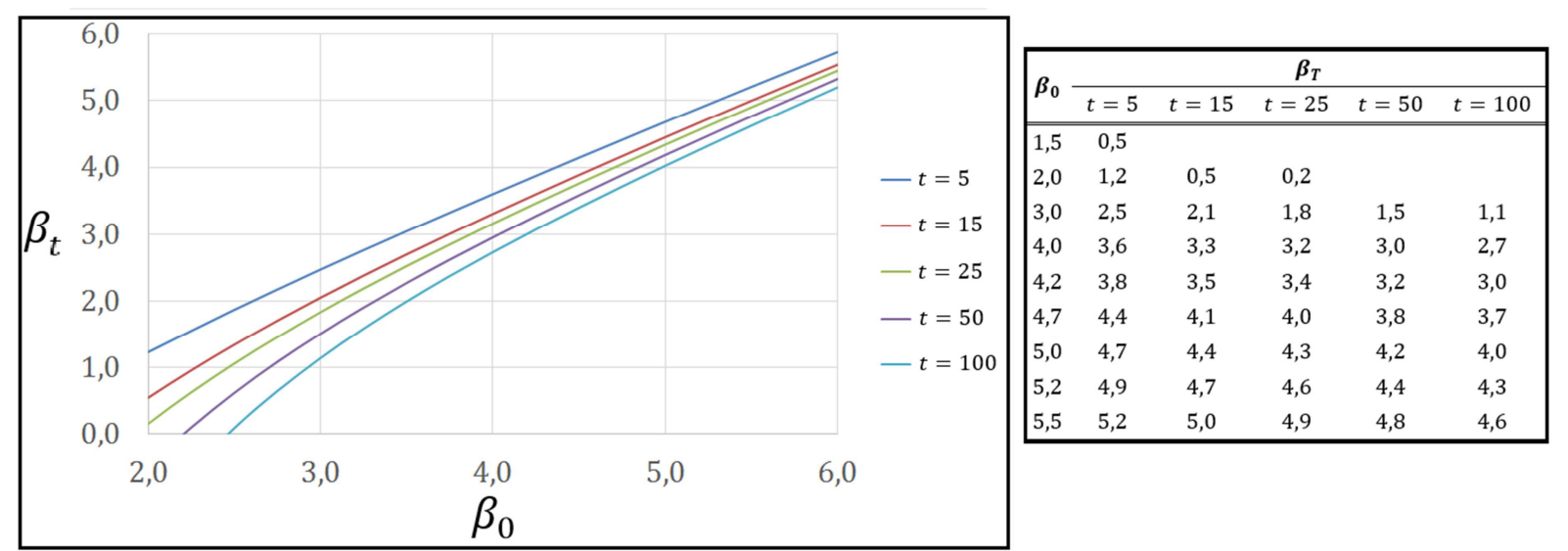

Figura $3.8-\beta_{t}$ vs $\beta_{0}$ 
$\mathrm{Na}$ Figura (3.9), observa-se que $\beta_{t}$ decai exponencialmente com o avanço do tempo $t$. Além disso, o histórico de decaimento dependerá dos valores de $\beta_{0}$.

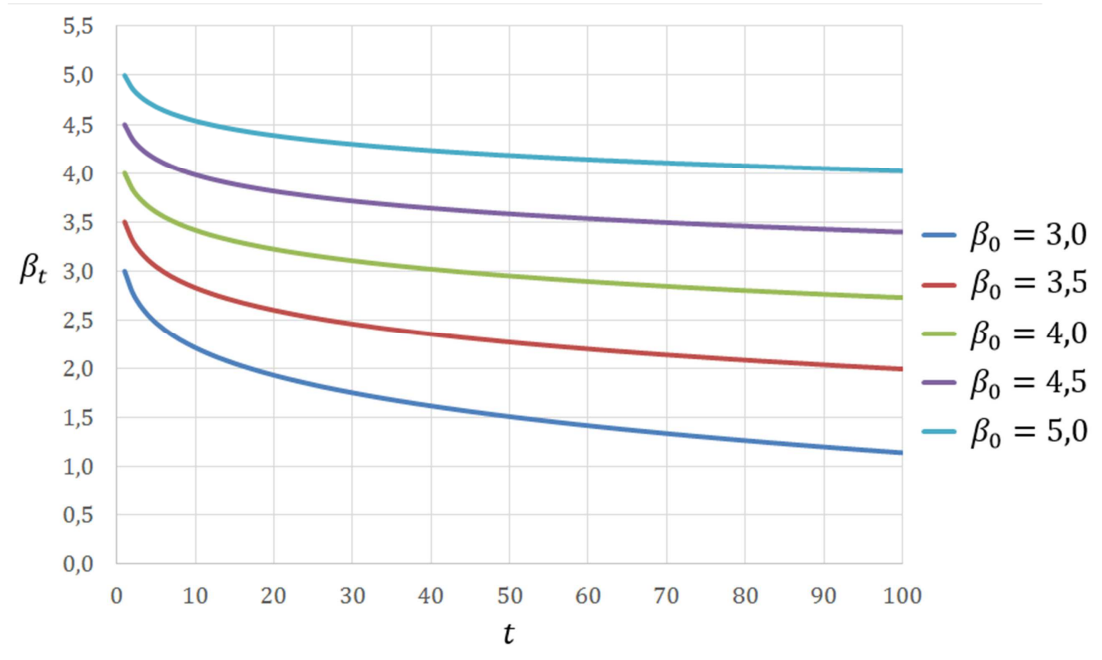

Figura 3.9 - Variação de $\beta_{t}$ com o avanço do tempo $t$

\subsection{Estado limite de iniciação da corrosão}

$\mathrm{Na}$ seção passada, discorreu-se sobre a evolução das filosofias de projeto envolvendo a incorporação das incertezas das variáveis, bem como sobre os índices de confiabilidade recomendados. Contudo, cabem aqui alguns questionamentos a respeito do objeto de estudo deste trabalho:

- A iniciação da corrosão é de fato um estado limite de serviço?

- Os índices de confiabilidade recomendados para estados limites de serviço são adequados como valores de referência para estados limites envolvendo a despassivação de armaduras?

- Qual seria um nível de confiabilidade adequado para um estado limite envolvendo a despassivação das armaduras?

Procurando responder a estas questões, Andrade (2017) apresenta um trabalho procurando diferenciar a iniciação da corrosão em estruturas de concreto armado dos demais estados limite.

A definição clássica de ELS, de acordo com diversas normas internacionais, é um estado que corresponde a condições além das quais os requisitos especificados de operacionalidade para uma estrutura ou seus componentes não são mais atendidos. Contudo, de um ponto de vista de engenharia, o estado limite de despassivação das armaduras não se encaixa completamente nesta definição pois, imediatamente após o início da corrosão (período de propagação), nenhum efeito prejudicial é constatado no nível estrutural e nenhum sinal de dano ou efeito é detectado. Todos os requisitos de operacionalidade continuam a ser atendidos durantes os primeiros estágios do processo corrosivo. Assim, o estado limite de iniciação de deterioração (ELI) é mais claramente 
definido de acordo com a norma ISO 13823 (2006): “um estado que corresponde a iniciação de deterioração significativa de um componente estrutural". É possível notar uma clara diferença entre esta definição e a de ELS.

A confiabilidade requerida para um ELI pode ser analisada para dois casos gerais:

- Limitação da concentração de cloretos na mistura de concreto em novas estruturas;

- Limitação da concentração de cloretos no cálculo da vida útil de estruturas novas ou já existentes onde deve-se considerar também o custo relativo de medidas de segurança e consequências de falha.

A Tabela (3.3) apresenta valores sugeridos para o índice de confiabilidade alvo associado a concentração limite de cloretos que ocasionam a despassivação em novas estruturas:

Tabela 3.3 - Limite de cloretos e sugestões de probabilidades de despassivação e índices de confiabilidade para novas estruturas (mistura de concreto). Adaptado de Andrade (2017).

\begin{tabular}{cccc}
\hline & $\begin{array}{c}\text { Concentração limite de } \\
\text { cloretos (\% da massa de } \\
\text { cimento) }\end{array}$ & $\begin{array}{c}\text { Probabilidade de } \\
\text { despassivação (\%) }\end{array}$ & $\begin{array}{c}\text { Índice de } \\
\text { confiabilidade alvo } \boldsymbol{\beta}_{\boldsymbol{T}}\end{array}$ \\
\hline \hline Concreto armado & 0,4 & 10,0 & 1,30 \\
\hline Concreto protendido & 0,2 & 1,0 & 2,32 \\
\hline
\end{tabular}

O valor de $0,4 \%$ para a concentração limite de cloretos e sua probabilidade de despassivação associada, proposto por Andrade (2017), estão baseados em resultados de testes laboratoriais realizados por Izquierdo et al. (2004) e por dados coletados em estruturas reais apresentados por Markeset (2009). Para as estruturas de concreto protendido não são feitas justificativas a respeito dos valores recomendados.

Para a previsão da confiabilidade associada à vida útil da estrutura, são sugeridos os valores reportados na Tabela (3.4).

Tabela 3.4 - Limite de cloretos e sugestões de probabilidades de despassivação e índices de confiabilidade para previsão da vida útil estrutural. Adaptado de Andrade (2017)

\begin{tabular}{ccccc}
\hline & $\begin{array}{c}\text { Consequências da } \\
\text { despassivação }\end{array}$ & $\begin{array}{c}\text { Concentração } \\
\text { limite de cloretos } \\
\text { (\% da massa de } \\
\text { cimento) }\end{array}$ & $\begin{array}{c}\text { Probabilidade de } \\
\text { despassivação } \\
\text { (\%) }\end{array}$ & $\begin{array}{c}\text { Índice de } \\
\text { confiabilidade } \\
\text { alvo } \boldsymbol{\beta}_{\boldsymbol{T}}\end{array}$ \\
\hline \hline \multirow{3}{*}{ Concreto armado } & Baixas & 0,7 & 50,0 & 0 \\
& Moderadas & 0,4 & 50,0 & 0 \\
\hline \multirow{2}{*}{ Concreto protendido } & Graves & 0,4 & 25,0 & 0,65 \\
& Baixas & 0,2 & 10,0 & 1,30 \\
& Moderadas & 0,2 & 5,0 & 1,65 \\
\hline
\end{tabular}


Os valores reportados na tabela são apenas valores de orientação, uma vez que os índices de confiabilidade alvo devem considerar questões como os custos de medidas de segurança, as consequências de falha e a duração da vida útil. Essas questões nem sempre são triviais de serem resolvidas.

As consequências de falha podem ser estimadas apenas por meio de modelos que possam prever o desenvolvimento e os efeitos da corrosão ao longo do tempo. Assim, a atribuição de um dado índice de confiabilidade só é possível a partir do conhecimento (ou estimativa) do que irá acontecer a uma estrutura conforme os diversos estágios de degradação ocasionados pela corrosão. Além disso, análises do ciclo de vida e otimização de custos são necessárias para avaliar mais precisamente as consequências de falha em termos de riscos, dependendo do tipo de estrutura.

Portanto, o reconhecimento de que o estado limite de iniciação da corrosão não segue a definição clássica de estado limite de serviço permite uma nova perspectiva sobre o assunto. Ao mesmo tempo, dificuldades técnicas surgem nesse contexto, o que torna a recomendação de índices de confiabilidade uma questão a ser ainda discutida e investigada.

\subsection{Métodos para estimativa da probabilidade de falha}

Conforme visto anteriormente, a probabilidade de falha pode ser calculada por meio da integral múltipla da função conjunta de densidade de probabilidade $f_{\boldsymbol{X}}(\boldsymbol{x})$ sobre o domínio de falha, conforme a Equação (3.9). Contudo, problemas como o desconhecimento de $f_{\boldsymbol{X}}(\boldsymbol{x})$, do domínio de falha e dificuldades no processo de integração, conduzem ao desenvolvimento e aplicação de métodos aproximados (não exatos) para a estimativa da probabilidade de falha. Alguns autores classificam tais métodos em níveis, conforme pode ser visto, por exemplo, na Tabela (3.5). 
Tabela 3.5 - Hierarquia dos métodos de medidas de confiabilidade estrutural. Adaptado de Melchers (1999)

\begin{tabular}{|c|c|c|c|c|c|}
\hline Nível & $\begin{array}{l}\text { Método de } \\
\text { cálculo }\end{array}$ & $\begin{array}{c}\text { Distribuição } \\
\text { de } \\
\text { probabilidades }\end{array}$ & $\begin{array}{l}\text { Equação de } \\
\text { estado limite }\end{array}$ & $\begin{array}{l}\text { Incerteza nos } \\
\text { dados }\end{array}$ & Resultado \\
\hline $\begin{array}{c}1 \\
\text { Normas técnicas }\end{array}$ & $\begin{array}{c}\text { (Calibração com } \\
\text { regras } \\
\text { normativas } \\
\text { utilizando nível } \\
2 \text { ou 3) }\end{array}$ & $\begin{array}{l}\text { Não são } \\
\text { utilizadas }\end{array}$ & $\begin{array}{l}\text { Funções lineares } \\
\text { (usualmente) }\end{array}$ & $\begin{array}{l}\text { Fatores } \\
\text { arbitrários }\end{array}$ & $\begin{array}{c}\text { Fatores de } \\
\text { segurança } \\
\text { parciais }\end{array}$ \\
\hline $\begin{array}{c}2 \\
\text { Métodos de } \\
\text { segundo } \\
\text { momento }\end{array}$ & $\begin{array}{l}\text { Álgebra em } \\
\text { segundo } \\
\text { momento }\end{array}$ & $\begin{array}{c}\text { Somente } \\
\text { distribuições } \\
\text { normais }\end{array}$ & $\begin{array}{l}\text { Linear ou com } \\
\text { aproximação } \\
\text { linear }\end{array}$ & $\begin{array}{l}\text { Podem ser } \\
\text { incluídas como } \\
\text { estatísticas de } \\
\text { segundo } \\
\text { momento }\end{array}$ & $\begin{array}{l}\text { Probabilidade } \\
\text { de falha nominal }\end{array}$ \\
\hline $\begin{array}{c}3 \\
\text { "Métodos } \\
\text { exatos" }\end{array}$ & $\begin{array}{c}\text { Integração } \\
\text { numérica }\end{array}$ & $\begin{array}{c}\text { Distribuições } \\
\text { normais } \\
\text { equivalentes } \\
\text { Utilização plena }\end{array}$ & $\begin{array}{c}\text { Linear ou com } \\
\text { aproximação } \\
\text { linear }\end{array}$ & $\begin{array}{l}\text { Podem ser } \\
\text { incluídas como } \\
\text { variáveis } \\
\text { aleatórias }\end{array}$ & $\begin{array}{l}\text { Probabilidade } \\
\text { de falha }\end{array}$ \\
\hline $\begin{array}{c}4 \\
\text { Métodos de } \\
\text { decisão }\end{array}$ & \multicolumn{4}{|c|}{$\begin{array}{l}\text { Qualquer um(a) acima } \\
\text { mações a respeito do custo de falha }\end{array}$} & $\begin{array}{l}\text { Custos mínimos } \\
\text { ou benefícios } \\
\text { máximos }\end{array}$ \\
\hline
\end{tabular}

Os métodos de nível 1 utilizam apenas um valor característico de cada variável, normalmente a média. Nesta abordagem são utilizados os fatores parciais de segurança, sendo assim métodos semiprobabilísticos, comumente utilizados nas normas de projeto de engenharia da atualidade.

Os métodos de nível 2 utilizam dois parâmetros de cada variável, normalmente a média e a variância. Além disso, podem admitir correlação entre as variáveis (covariância), porém consideram apenas distribuições de probabilidades normais. O FOSM (First Order Second Moment) é um exemplo de método de confiabilidade de nível 2. Neste método, a equação de estado limite é aproximada por um hiperplano (linearização de uma equação não-linear multidimensional) no ponto de projeto (ponto pertencente a equação de estado limite que possui o maior conteúdo de probabilidades associado).

Os métodos de nível 3 são a melhor forma de estimar a probabilidade de falha, pois admitem variáveis não-normais e equações de estado limite não-lineares. São chamados de "métodos exatos" pois o procedimento estatístico é exato, porém a probabilidade de falha calculada continua a ser apenas uma estimativa. Neste nível existem duas metodologias prevalentemente utilizadas: técnicas de transformação e técnicas de simulação. Dentre as técnicas de transformação mais populares cita-se o FORM e o SORM. O FORM é similar ao FOSM, pois busca linearizar a equação de estado limite no ponto de projeto, porém as variáveis aleatórias, com quaisquer tipos de distribuição, são primeiro mapeadas para um espaço normal padrão 
correlacionado e em seguida as correlações entre os pares de variáveis são eliminadas. O SORM é idêntico ao FORM, porém, diferencia-se por aproximar a equação de estado limite por uma função de segunda ordem no ponto de projeto. Já entre as técnicas de simulação, a mais utilizada é o método de simulação de Monte Carlo (MSMC). Neste método, todas as informações estatísticas são consideradas e a probabilidade de falha é calculada por meio de um número finito de experimentos aleatórios. A grande vantagem deste método é que a probabilidade de falha por ele estimada tende a ser próxima da probabilidade de falha exata se um número adequado de simulações for realizado. Como este é o método utilizado neste trabalho, uma descrição do mesmo é feita em detalhes adiante.

Por fim, os métodos de nível 4, também chamados de "métodos de decisão", confrontam a confiabilidade da estrutura com uma confiabilidade de referência à luz de princípios econômicos sob incertezas como os custos de construção, manutenção, reparo, consequências de falha, etc. Esse tipo de método é adequado para estruturas de elevada importância e com altos custos de falha esperados, como pontes, barragens e usinas nucleares.

\subsection{Método de simulação de Monte Carlo}

\subsubsection{Introdução}

Uma "simulação" pode ser interpretada sob diversos aspectos. Num contexto numérico, consiste na realização de experimentos virtuais com base em modelos lógicos e matemáticos, a fim de imitar um processo do mundo real. Na matemática, a simulação é uma valiosa ferramenta no cálculo de equações e operações complexas. Essas duas definições estão perfeitamente inseridas na área da engenharia estrutural.

O método de simulação de Monte Carlo (MSMC) é um dos métodos de simulação mais conhecidos e utilizados na atualidade. A versão mais difundida da origem desse método remete aos anos de 1940, onde cientistas trabalhavam no desenvolvimento de armas nucleares nos Estados Unidos. Por ser um projeto sigiloso, os cientistas adotaram "Monte Carlo" como um codinome, em referência ao casino de Monte Carlo, localizado no Principado de Mônaco, famoso por jogos envolvendo aleatoriedade.

Este método é aplicado atualmente nas mais diferentes áreas do conhecimento. $\mathrm{Na}$ física ele é utilizado para cálculos quânticos para projeto de escudos térmicos e formas aerodinâmicas, bem como para modelar a radiação. Na biologia é utilizado para estudar sistemas como genomas, proteínas e membranas. $\mathrm{Na}$ área de finanças o método permite incorporar os efeitos das incertezas nas variáveis como volume de vendas, mão-de-obra, juros, taxas de câmbio, risco de 
cancelamento de contratos, etc. O MSMC é inclusive aplicado na indústria de videogames para desenvolvimento de técnicas de inteligência artificial.

O MSMC pode ser entendido de uma maneira simplificada por meio de um experimento envolvendo o lançamento de um dado. Seja $E$ o evento que representa a face superior do dado possuir um valor específico (igual a 3, por exemplo) após o lançamento. Se forem realizados $n$ lançamentos até um dado instante (ou seja, tem-se $n$ amostras), a probabilidade de ocorrência constatada do evento $E$ por meio desses experimentos sucessivos é igual a:

$P[E]=\frac{n_{e}}{n}$

em que $n_{e}$ é o número de vezes que o evento $E$ ocorreu ao longo de todos os $n$ experimentos. Se o lançamento do dado for repetido um número muito grande de vezes (em termos hipotéticos, um número de vezes tendendo ao infinito), a probabilidade de ocorrência do evento $E$ será igual a:

$P[E]=\lim _{n \rightarrow \infty} \frac{n_{e}}{n}$

Essa equação coincide exatamente com a definição frequentista de probabilidade, onde calcula-se a probabilidade após a realização de experimentos.

A partir do experimento do lançamento de dado descrito, onde buscou-se calcular qual é a probabilidade da face superior possuir um valor específico, realiza-se aqui uma analogia para o cálculo da probabilidade de que uma estrutura viole um dado estado limite preestabelecido (probabilidade de falha). Em termos hipotéticos, um modelo ou componente estrutural pode ser construído e testado $n$ vezes. Após cada teste feito, caso ocorra a violação do estado limite preestabelecido, contabiliza-se uma falha. Somando-se o número de vezes que a falha foi constatada e dividindo-se pelo número total de estruturas testadas obtém-se a probabilidade de falha. Contudo, a realização real de testes em estruturas para o cálculo da probabilidade de falha encontra enormes dificuldades.

Dentre essas dificuldades destaca-se que a probabilidade de falha de estruturas e componentes estruturais é geralmente muito pequena para estados limites usuais, o que exigiria a realização de um grande número de testes para que uma quantidade satisfatória de falhas fosse observada, a fim de estimar a probabilidade de falha. Além disso, os custos envolvidos na confecção e ensaio de protótipos estruturais pode ser muito elevado. Mesmo utilizando modelos estruturais em escala, o cálculo da probabilidade de falha por experimentação seria inviável.

Dessa forma, no MSMC, os experimentos são realizados por meio de simulações de computador. Conjuntos de valores aleatórios são gerados sistematicamente para os parâmetros de entrada obedecendo as distribuições estatísticas das variáveis envolvidas. Para cada conjunto de 
valores amostrado investiga-se a ocorrência ou não da falha e em seguida calcula-se a probabilidade de falha. A seguir a formulação do método é apresentada.

\subsubsection{Formulação}

O MSMC possui as seguintes etapas:

- Geração de amostras aleatórias;

- Avaliação da ocorrência da falha;

- Estimativa da probabilidade de falha e sua variância.

Cada uma dessas etapas é descrita a seguir.

\subsubsection{Geração de amostras aleatórias}

As diversas formas com que se pode gerar amostras aleatórias necessárias para a realização das simulações são chamadas de "técnicas de amostragem". A técnica de amostragem mais geral consiste, em primeiro lugar, gerar um número aleatório $u_{i}$, com distribuição uniforme de probabilidades e valores compreendidos no intervalo [0,1]. Em seguida, uma amostra $x_{i}$ da variável aleatória $X_{i}$ pode ser gerada a partir da seguinte operação:

$x_{i}=F_{X_{i}}^{-1}\left(u_{i}\right)$

em que $F_{X_{i}}^{-1}$ é a inversa da função de distribuição acumulada da variável $X$. Para determinados tipos de distribuição de probabilidades, $F_{X_{i}}^{-1}$ não possui uma solução fechada. Contudo, para cada tipo de distribuição, existem soluções numéricas disponíveis na literatura para o cálculo aproximado dessa função. $\mathrm{Na}$ atualidade, diversos softwares já possuem em seu ferramental a possibilidade de geração de números aleatórios e a capacidade de calcular $F_{X_{i}}^{-1}$ para diversos tipos de distribuição.

Uma observação importante diz respeito a consideração (ou não) da correlação entre as variáveis aleatórias no processo de geração de amostras. Caso as variáveis aleatórias sejam consideradas não correlacionadas, a função conjunta de densidade de probabilidade é simplesmente o produtório das funções de densidade marginais de cada variável, o que implica que as amostras podem ser geradas de forma independente umas das outras. Porém, caso a correlação entre as variáveis aleatórias for considerada, o processo de geração de amostras poderá ser feito por meio do modelo de Nataf. Nesse modelo, as amostras são geradas primeiramente em um espaço normal padrão não correlacionado e em seguida são correlacionadas por meio de uma matriz Jacobiana obtida pelo processo de decomposição ortogonal ou de Cholesky da matriz de correlação equivalente. $\mathrm{Na}$ segunda transformação as amostras são levadas para o espaço 
normal real por meio do cálculo da inversa da função de distribuição acumulada, conforme foi anteriormente apresentado. No presente trabalho, considera-se que as variáveis aleatórias não possuem correlação.

Existem também outras formas particulares para geração de amostras aleatórias. Tais técnicas, em geral, reduzem a quantidade de amostras necessárias (e consequentemente de simulações) para uma adequada estimativa da probabilidade de falha. Entre essas técnicas cita-se: amostragem por importância utilizando pontos de projeto, amostragem por importância adaptativa, amostragem por hiper-cubo latino, amostragem assintótica e amostragem por subconjunto. Para mais detalhes sobre este tópico pode-se consultar os livros de Melchers (1999) e Nowak e Collins (2000).

\subsubsection{Avaliação da ocorrência da falha}

Conforme já descrito anteriormente, a probabilidade de falha pode ser calculada por meio da seguinte equação:

$P_{f}=\int \ldots \int_{\Omega_{f}} f_{X}(\boldsymbol{x}) d \boldsymbol{x}$

O domínio de falha para um único modo de falha é dado por:

$\Omega_{f}=G(x<0)$

Quando dois ou mais modos de falha são considerados, os domínios de falha para sistemas em série, paralelo e associação mista são dados por:

$\Omega_{f, \text { série }}=\bigcup_{i=1}^{n} G_{i}(x<0)$
$\Omega_{f, \text { paralelo }}=\bigcap_{i=1}^{n} G_{i}(x<0)$

$\Omega_{f, \text { misto }}=\bigcap_{j=1}^{m}\left[\bigcup_{i=1}^{n} G_{i}(\boldsymbol{x}<0)\right]_{j}$

Introduzindo na Equação (3.30) a função $I[$.$] , tem-se:$

$P_{f}=\int \ldots \int_{\Omega_{f}} I[G(\boldsymbol{x})] f_{\boldsymbol{X}}(\boldsymbol{x}) d \boldsymbol{x}$

em que $I[$. ] é chamada de função indicadora, assumindo os seguintes valores:

$I[G(\boldsymbol{x})]=1$ se $G(\boldsymbol{x}) \leq 0$ 


$$
I[G(\boldsymbol{x})]=0 \text { se } G(\boldsymbol{x})>0
$$

Assim, a função indicadora irá avaliar se a falha ocorreu ou não a partir do valor assumido pela equação de estado limite para uma dada amostra aleatória $\boldsymbol{x}$.

\subsubsection{Estimativa da probabilidade de falha e sua variância}

Observa-se que a Equação (3.33) corresponde ao valor esperado da função indicadora $I[G(\boldsymbol{x})]$. Adotando uma amostra de tamanho finito igual a $n_{\text {sim }}$ (número de simulações), a probabilidade de falha estimada $\overline{P_{f}}$ é igual a:

$\overline{P_{f}}=\frac{1}{n_{\text {sim }}} \sum_{i=1}^{n_{\text {sim }}} I\left[G\left(\boldsymbol{x}_{\boldsymbol{i}}\right)\right]=\frac{n_{f}}{n_{\text {sim }}}$

em que $n_{f}$ é o número de vezes que uma amostra $\boldsymbol{x}_{\boldsymbol{i}}$ resultou em uma falha. A variância da probabilidade de falha estimada pode ser computada por meio da expressão:

$\operatorname{Var}\left[\bar{P}_{f}\right]=\frac{1}{n_{\text {sim }}-1} \sum_{i=1}^{n_{\text {sim }}}\left(I\left[G\left(\boldsymbol{x}_{\boldsymbol{i}}\right)\right]-\bar{P}_{f}\right)^{2}$

Observa-se que se o número de simulações tender para o infinito, a variância converge para zero. Isso significa que a probabilidade de falha terá uma melhor estimativa (menor incerteza) quão maior for o número de simulações realizadas.

O número de amostras necessário para uma adequada estimativa da probabilidade de falha pode ser determinado por meio de diversas expressões disponíveis na literatura. Broding et al. (1964) sugerem que o número de simulações necessário $n_{\text {sim,nec }}$, para um dado nível de confiança $C$ e uma probabilidade de falha esperada $P_{f, e s p}$ pode ser obtido por meio da equação:

$n_{\text {sim }, \text { nec }}>\frac{-\ln (1-C)}{P_{f, e s p}}$

Para problemas típicos de engenharia estrutural, $P_{f, e s p}$ é da ordem de $10^{-3}$ a $10^{-6}$. Considerando um nível de confiança de $95 \%$ e $P_{f, e s p}=10^{-3}, 10^{-4}, 10^{-5}$ e $10^{-6}$, o número de simulações resulta aproximadamente igual a $3 \times 10^{3}, 3 \times 10^{4}, 3 \times 10^{5}$ e $3 \times 10^{6}$. Já para El Hami e Radi (2013), considerando um grau de confiança de $95 \%$ e um erro conhecido de $20 \%$ nos resultados, o número mínimo de simulações é da ordem de $10^{\mathrm{n}+2}$ a $10^{\mathrm{n}+3}$ para probabilidades de falha esperadas em torno de $10^{-\mathrm{n}}$.

A previsão de um número de simulações necessárias, apesar de não possuir uma metodologia definitiva para sua determinação, é bastante útil para uma primeira estimativa. Contudo, uma interessante ferramenta de controle consiste numa análise de convergência da 
probabilidade de falha com o avanço das simulações. Neste tipo de análise é possível verificar a taxa de convergência e estabilidade do processo de simulação.

\subsection{Exemplos de aplicação}

\subsubsection{Exemplo 1: comparativo MEC e $2^{\mathrm{a}}$ lei de Fick em um domínio retangular via} MSMC

O seguinte exemplo possui a mesma geometria e condições de contorno apresentadas no exemplo 6 do capítulo 2 da presente tese, porém agora consideram-se as incertezas envolvidas no processo de difusão. O efeito de tais incertezas é avaliado em termos de probabilidade de despassivação. A geometria e as condições de contorno são repetidas aqui por conveniência e apresentadas nas figuras a seguir:

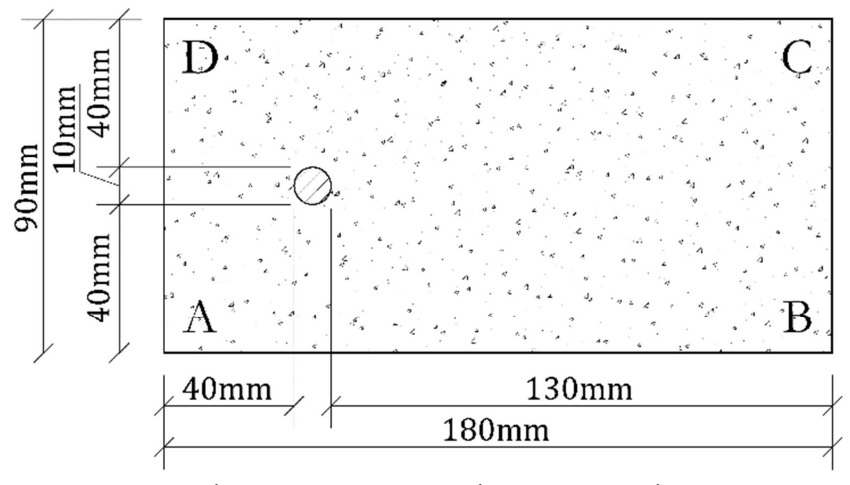

Figura 3.10 - Exemplo 1: geometria

\section{$\underline{\text { Caso } 1}$}

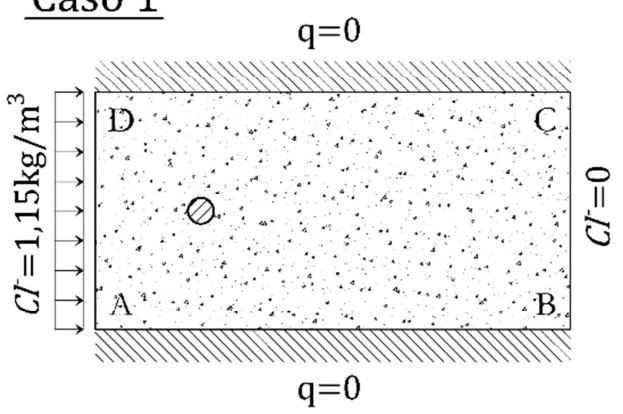

Caso 3

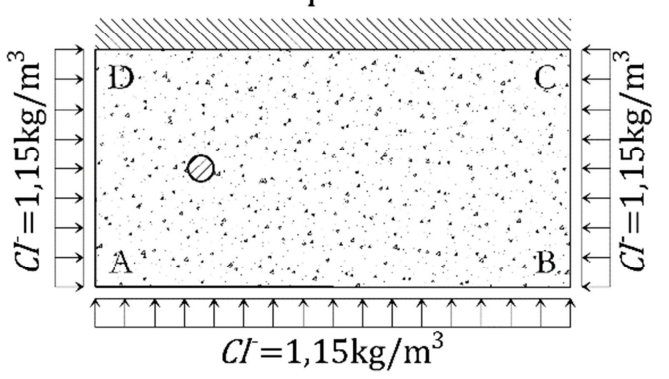

\section{Caso 2}

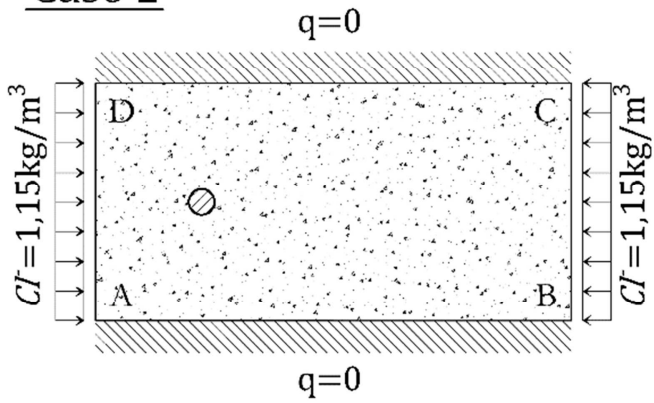

$\underline{\text { Caso } 4}$

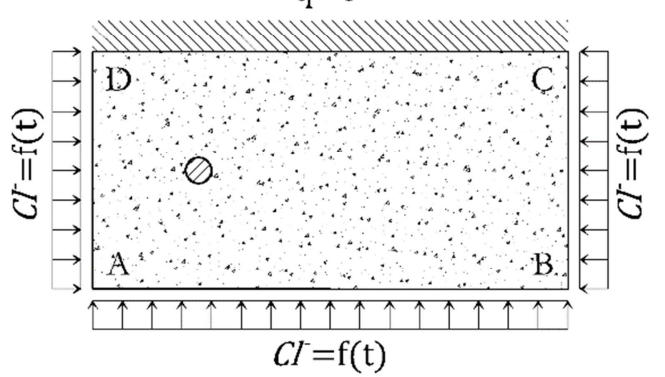

Figura 3.11 - Exemplo 1: condições de contorno para cada caso 
A equação de estado limite que define o limiar entre a ocorrência ou não da despassivação pode ser escrita da seguinte forma:

$G=C_{\text {lim }}-C(x, t)$

em que $C_{\text {lim }}$ é a concentração de cloretos limite para que ocorra a despassivação e $C(x, t)$ é a concentração de cloretos em um determinado ponto $x$ em um instante de tempo $t$. Essa equação de estado limite pode ser reescrita, de forma equivalente, em termos de tempo para ocorrência de despassivação:

$G=t_{\text {desp }}-t_{\text {v.u.p. }}$

em que $t_{\text {desp }}$ é o tempo para que ocorra a despassivação e $t_{v . u . p .}$ é o tempo de vida útil de projeto. A probabilidade de despassivação pode então ser calculada por meio da equação:

$P[G<0]=P\left[C_{\text {lim }}-C(x, t)<0\right]=P\left[t_{\text {desp }}-t_{\text {v.u.p. }}<0\right]$

No presente exemplo, a equação de estado limite assumida refere-se a tempos e não a concentrações. O método de simulação de Monte Carlo (MSMC) é utilizado para avaliar a Equação (3.40). O tempo para despassivação é calculado por meio do modelo descrito no presente trabalho utilizando o método dos elementos de contorno (MEC) e também por meio da lei de Fick. A lei de Fick unidimensional é dada por:

$C(x, t)=C_{0} \operatorname{erfc}\left[\frac{x}{2 \sqrt{\kappa_{0} t}}\right]$

em que $C_{0}$ é a concentração de íons cloretos no contorno do domínio, $x$ é a distância em linha reta entre o contorno e um ponto no interior de um domínio semi-infinito, $\kappa_{0}$ é o coeficiente de difusão, $t$ é o tempo transcorrido do processo difusivo e erfc é a função matemática de valor complementar da função erro de Gauss. Para se calcular o tempo para que ocorra a despassivação em um determinado ponto $x$ basta assumir $C(x, t)$ como sendo igual a concentração limite de cloretos $C_{\text {lim }}$ e isolar a variável $t$ dessa equação, obtendo-se:

$t_{\text {desp }}=\frac{1}{\kappa_{0}}\left[\frac{x}{2 \operatorname{erfc}^{-1}\left(\frac{C_{\text {lim }}}{C_{0}}\right)}\right]^{2}$

em que $\operatorname{erfc}^{-1}$ é a inversa da função matemática de valor complementar da função erro de Gauss.

Os parâmetros das variáveis aleatórias consideradas são: 
Tabela 3.6 - Exemplo 1: parâmetros das variáveis aleatórias

\begin{tabular}{ccccc}
\hline Parâmetro & $\begin{array}{c}\text { Tipo de } \\
\text { distribuição }\end{array}$ & Média & C.V. & Referência \\
\hline$C_{\text {lim }}$ & Uniforme & $0,60 \mathrm{~kg} / \mathrm{m}^{3}$ & 0,1443 & Mehta e Monteiro (2008) \\
\hline$\kappa_{0}$ & Lognormal & $67,7228 \mathrm{~mm}^{2} /$ ano & 0,50 & Bentz et al. (1996) \\
\hline$C_{0}$ & Lognormal & $1,15 \mathrm{~kg} / \mathrm{m}^{3}$ & 0,50 & $\begin{array}{c}\text { McGee (1999) / Val e } \\
\text { Stewart (2003) }\end{array}$ \\
\hline
\end{tabular}

O valor da posição do ponto $x$ não foi assumida como sendo uma variável aleatória para que se pudesse analisar a evolução das probabilidades de despassivação frente as incertezas para diversas profundidades.

No caso 4, onde as condições de contorno são variáveis no tempo, assume-se que a concentração média dos cloretos no contorno tenha o seguinte comportamento:

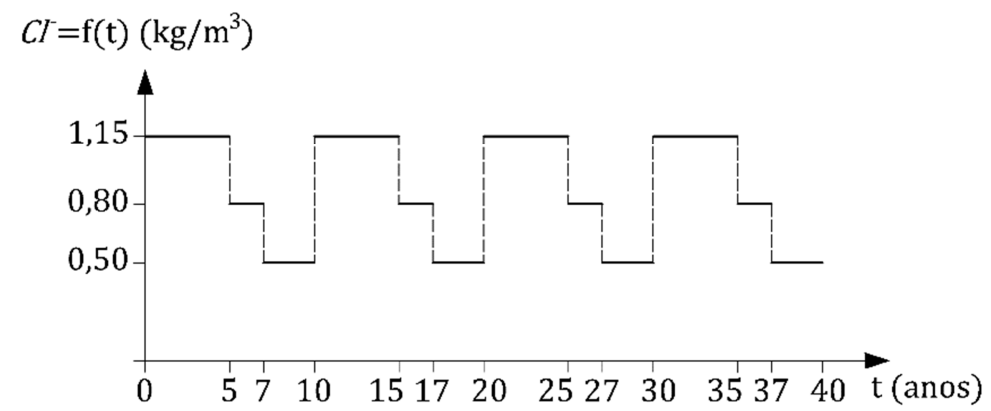

Figura 3.12 - Exemplo 1: variação da concentração média de cloretos no contorno para o caso 4

Para a solução numérica via MEC o contorno foi discretizado em 54 elementos descontínuos e isoparamétricos de aproximação linear com $10 \mathrm{~mm}$ de comprimento cada um, totalizando 108 nós e 216 graus de liberdade. Utilizam-se 10 pontos de Gauss por elemento para a integração numérica. Assume-se que o domínio possua potencial nulo no instante $t=0$ (no início da análise). Além disso, assume-se que o valor do potencial e do fluxo em cada ponto do domínio e do contorno permaneçam constantes em cada passo de tempo.

A discretização temporal foi feita em 40 passos de tempo partindo-se do ano 0 até o ano 40, ou seja, com $\Delta t=1$ ano. A fim de assegurar uma adequada escolha de discretização temporal, uma análise de convergência foi realizada, sendo que o valor de $\Delta t=1$ ano resultou em uma convergência no cálculo da probabilidade de despassivação. Passos de tempo de tamanho adaptativo poderiam ser utilizados a fim de acelerar o processo de cálculo, porém tal estratégia não foi implementada. 
Foram adotados pontos internos espaçados de $2 \mathrm{em} 2 \mathrm{~mm}$ ao longo de uma linha conectando os pontos médios dos lados $\mathrm{DA}$ e $\mathrm{BC}$, de forma que esta linha intercepte a armadura contida no interior do concreto. Assim sendo, o termo "profundidade" nesse exemplo é interpretado como sendo um ponto pertencente a esta linha, com uma coordenada definida a partir de uma origem localizada no ponto médio do lado DA.

No método de simulação de Monte Carlo foram utilizadas dez mil amostras em cada análise feita. O número de amostras escolhido foi adequado e verificado por meio de uma análise de convergência.

As evoluções das probabilidades de despassivação em função da profundidade do ponto $x$, para todos os casos, estão apresentadas na Figura 3.13. As evoluções das probabilidades de despassivação em função do tempo até a despassivação, ou seja, em função do tempo de vida útil de projeto desejado $t_{v . u . p .}$, para todos os casos, estão na Figura 3.14.
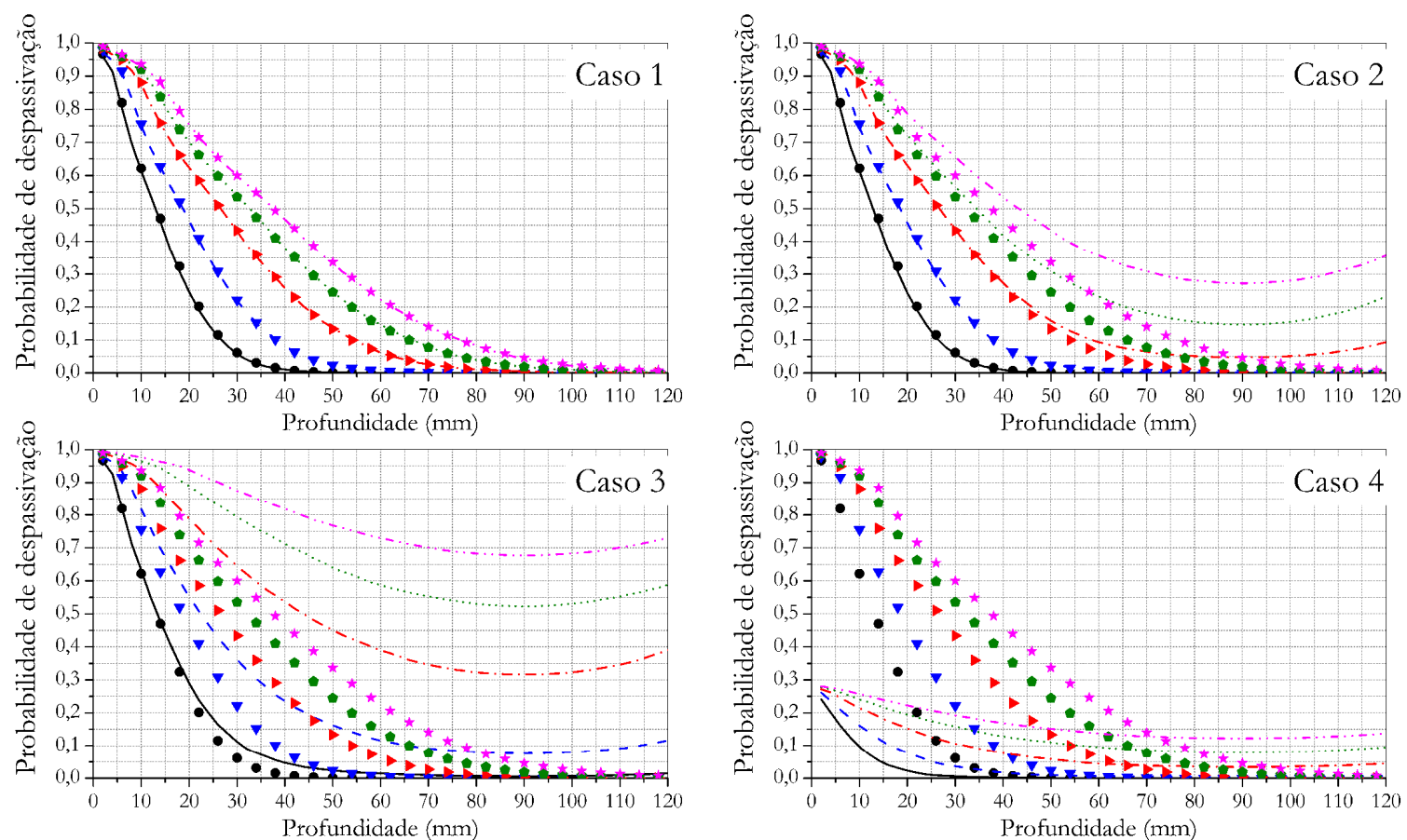

$\begin{array}{lll}\longrightarrow \text { MEC } \mathrm{t}=5 \text { anos } & \bullet & \text { Fick } \mathrm{t}=5 \text { anos } \\ \cdots \cdots \text { MEC } \mathrm{t}=20 \text { anos } & \succ & \text { Fick } \mathrm{t}=20 \text { anos } \\ \cdots \cdots-\text { MEC } \mathrm{t}=40 \text { anos } & \star & \text { Fick } \mathrm{t}=40 \text { anos }\end{array}$

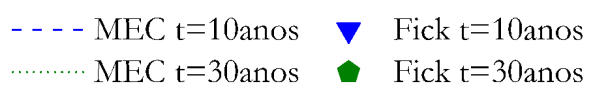

Figura 3.13 - Exemplo 1: Probabilidade de despassivação x Profundidade 

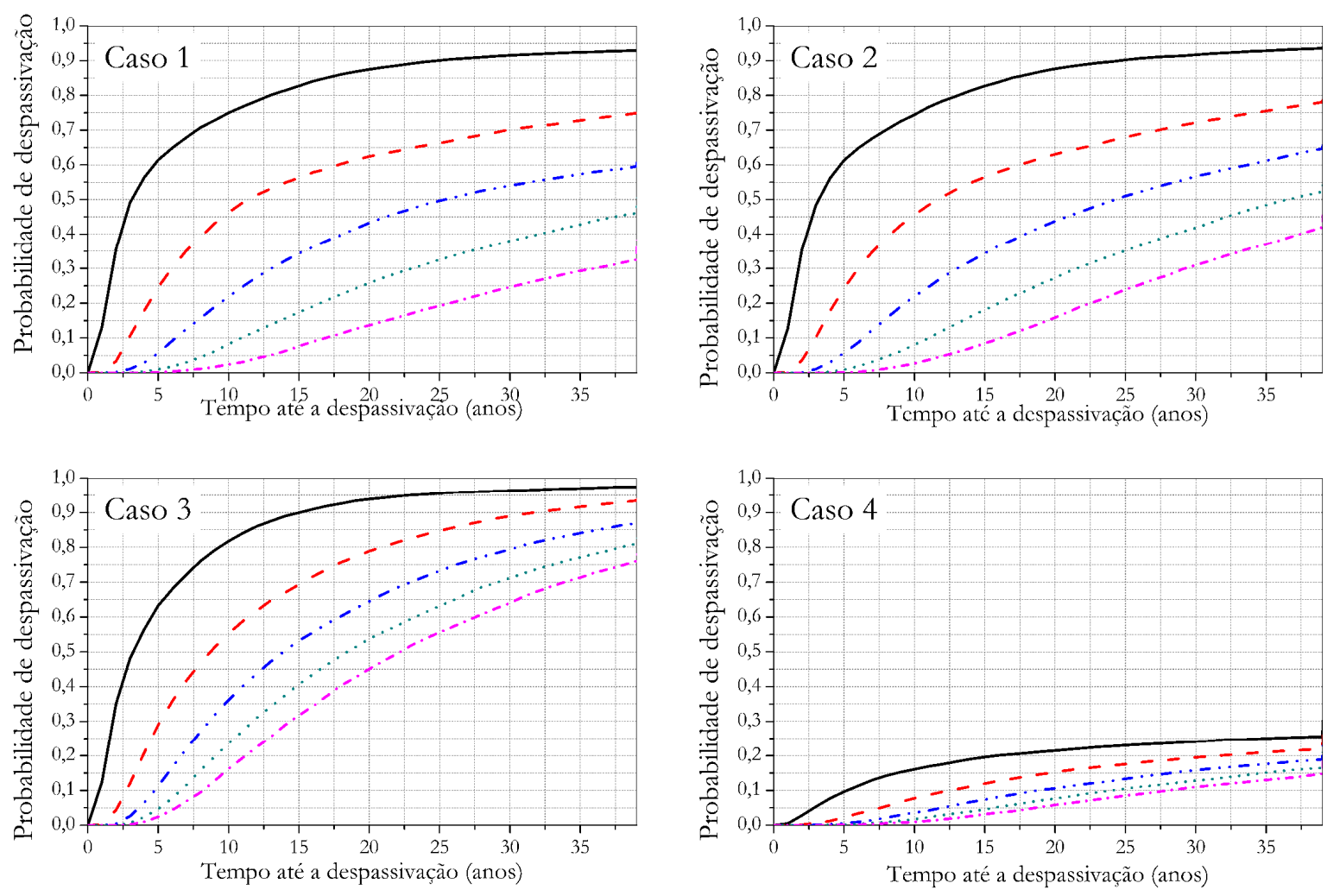

- MEC Cob. $=10 \mathrm{~mm} \quad--$ MEC Cob. $=20 \mathrm{~mm}$
$\cdots \cdots$ MEC Cob. $=40 \mathrm{~mm} \quad-\cdots \cdot$ MEC Cob. $=50 \mathrm{~mm}$

$-\cdots \cdot$ MEC Cob. $=30 \mathrm{~mm}$

Figura 3.14 - Exemplo 1: Probabilidade de despassivação x Tempo até a despassivação

Para o caso 1, observa-se que as probabilidades de despassivação utilizando-se o MEC e a lei de Fick apresentaram uma evolução praticamente idêntica. Isso já era esperado, uma vez que na análise determinística foi possível notar que os perfis de concentração de cloretos ao longo da profundidade entre os dois modelos apresentam uma concordância quase que plena. As pequenas diferenças existentes resultaram do erro associado ao processo de marcha no tempo do MEC. As respostas obtidas, em termos de probabilidades de despassivação, via lei de Fick e via MEC, resultaram cada vez mais distintas entre si ao longo dos casos, conforme as condições de contorno adotadas no modelo numérico se distanciavam das hipóteses assumidas na lei de Fick.

Observou-se que a lei de Fick e o MEC, para alguns pouquíssimos mesmos valores amostrados, ao longo das simulações de Monte Carlo, resultaram em tempos de despassivação bastante distintos. Essa diferença é verificada pois o tempo para ocorrência de despassivação calculado por meio da lei de Fick (Equação 3.42) pode resultar em um valor muito alto caso o argumento da inversa da função complementar do erro de Gauss $\left(\operatorname{erfc}^{-1}().\right)$ tender para um, ou seja, caso a razão $C_{l i m} / C_{0}$ tender para um, uma vez que $\operatorname{erfc}^{-1}(1)=0$. Em outras palavras, quando o gradiente de concentração de cloretos tender para zero, o tempo para ocorrência da despassivação tende para infinito. 
Para os primeiros anos após o início do processo de difusão, a taxa de crescimento da concentração de cloretos é maior para pontos em pequenas profundidades, conforme observado na análise determinística. Tal resultado é refletido na análise probabilística, sendo que a taxa de crescimento da probabilidade de despassivação é também maior nesses pontos localizados em pequenas profundidades nas primeiras idades após o início do processo de difusão.

Em cada caso, os tempos de despassivação determinísticos, obtidos pelo modelo via MEC, possuem probabilidades associadas diferentes. Por exemplo, considerando a armadura de referência posicionada a $40 \mathrm{~mm}$ de profundidade, os tempos de despassivação determinísticos calculados para os casos 1 a 4 resultaram iguais a 29,26, 13 e 18 anos, com suas probabilidades de despassivação respectivas iguais a $37 \%, 37 \%, 34 \%$ e $7 \%$. Agora considerando-se uma probabilidade de despassivação fixa de $15 \%$ para a mesma profundidade de $40 \mathrm{~mm}$, os tempos para ocorrência da despassivação associados a tal probabilidade para os casos de 1 a 4 são iguais a 13, 13, 8 e 34 anos. Os casos 1 e 2 tiveram seus resultados bastante parecidos por causa das condições de contorno dos problemas serem semelhantes, sendo que a resposta começa a apresentar uma notável diferença apenas para idades mais avançadas.

Poucas normas apresentam valores de referência de índices de confiabilidade para a despassivação das armaduras. Uma delas é o fib Model Code (MC2010, 2012). Nessa norma, considerando-se a despassivação como um estado limite de serviço, apresentam-se dois valores para o índice de confiabilidade: $\beta=1,3$ (probabilidade de falha por volta de $10 \%$ ) e $\beta=1,5$ (probabilidade de falha por volta de 7\%). Contudo, não fica claro qual valor de $\beta$ utilizar e nem se tal valor possui uma justificativa conforme o nível de agressividade ambiental do local onde a estrutura está inserida e muito menos das condições de contorno do processo de transporte de íons.

Assim, como demonstrado no exemplo, as condições de contorno exercem um papel decisivo no histórico de probabilidade de despassivação. Considerar apenas um único índice de confiabilidade alvo para diversos possíveis casos é excessivamente generalista, podendo resultar a favor ou contra a segurança. A resposta probabilística à despassivação para diferentes níveis de agressividade ambiental é ilustrada no próximo exemplo.

\subsubsection{Exemplo 2: domínio em formato de T e curvas de isoprobabilidade de}

\section{despassivação}

Neste exemplo, é analisado um processo de difusão de íons cloreto em uma seção transversal composta por uma viga de concreto de $20 \times 65 \mathrm{~cm}$ incorporada a uma laje de $15 \mathrm{~cm}$ de espessura. A seção transversal é submetida a uma penetração de íons cloreto com concentração 
média igual a $C s_{1}$ em sua face superior e igual a $C s_{2}$ nas demais faces, exceto nas faces laterais da laje. A seção transversal estudada e as condições de contorno são ilustradas na Fig. 3.15.

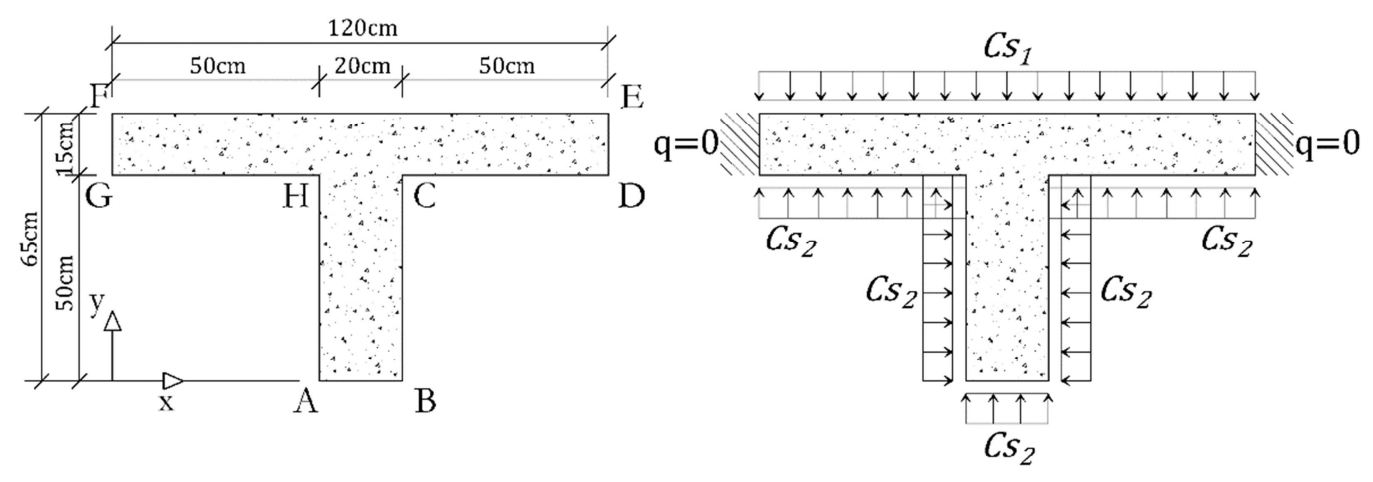

(a)

(b)

Figura 3.15 - Exemplo 2: geometria (a) e condições de contorno (b)

O posicionamento das armaduras não é ilustrado, pois, nesta análise, são obtidas curvas de isoprobabilidade de despassivação para vários pontos do domínio. Uma vez conhecidas as curvas de isoprobabilidade, é possível visualizar o nível de segurança à despassivação associado ao posicionamento das armaduras na seção transversal.

Para a solução numérica via MEC o contorno é discretizado em 74 elementos descontínuos e isoparamétricos de aproximação quadrática com $5 \mathrm{~cm}$ de comprimento cada, totalizando 222 nós e 444 graus de liberdade. O número de pontos de Gauss por elemento para a integração numérica é igual a 10. A discretização temporal foi feita em 33 passos de tempo começando do ano 0 até o ano 99. Assume-se que o potencial no domínio é nulo no tempo $t=0$ (no começo da análise). Além disso, assume-se que o valor do potencial e do fluxo em cada ponto do domínio e do contorno permaneçam constantes em cada passo de tempo. Uma análise de convergência de malha foi previamente realizada a fim de determinar uma discretização adequada do contorno para o problema.

A concentração superficial de cloretos adotada foi escolhida a partir do trabalho de McGee (1999) considerando três níveis de agressividade ambiental. A concentração limite de cloretos adotada foi aquela do trabalho de Mehta e Monteiro (2008). Outros parâmetros estatísticos foram adotados a partir do trabalho de Val e Stewart (2003). A Tabela 3.7 apresenta os valores aleatórios envolvidos na difusão de cloretos e no problema de confiabilidade. 
Tabela 3.7 - Exemplo 2: parâmetros estatísticos para a análise de difusão com o MEC

\begin{tabular}{|c|c|c|c|c|}
\hline $\begin{array}{c}\text { Nível de } \\
\text { agressividade } \\
\text { ambiental }\end{array}$ & Parâmetro & $\begin{array}{c}\text { Tipo de } \\
\text { distribuição }\end{array}$ & Média & C.V. \\
\hline Todos & Concentração limite de cloretos $C_{\text {lim }}$ & Uniforme & $0,90 \mathrm{~kg} / \mathrm{m}^{3}$ & 0,19 \\
\hline Todos & Coeficiente de difusão do concreto $\kappa$ & Lognormal & $0,2305720 \mathrm{~cm}^{2} /$ ano & 0,50 \\
\hline Moderado/Normal & $\begin{array}{l}\text { Concentração superficial de cloretos } C s_{1} \\
\text { Concentração superficial de cloretos } C s_{2}\end{array}$ & \multirow{3}{*}{ Lognormal } & $\begin{array}{l}1,15 \mathrm{~kg} / \mathrm{m}^{3} \\
0,92 \mathrm{~kg} / \mathrm{m}^{3} \\
\end{array}$ & 0,50 \\
\hline Alto & $\begin{array}{l}\text { Concentração superficial de cloretos } C s_{1} \\
\text { Concentração superficial de cloretos } C s_{2}\end{array}$ & & $\begin{array}{l}2,95 \mathrm{~kg} / \mathrm{m}^{3} \\
2,36 \mathrm{~kg} / \mathrm{m}^{3}\end{array}$ & 0,75 \\
\hline Extremo & $\begin{array}{l}\text { Concentração superficial de cloretos } C s_{1} \\
\text { Concentração superficial de cloretos } C s_{2}\end{array}$ & & $\begin{array}{l}7,35 \mathrm{~kg} / \mathrm{m}^{3} \\
5,88 \mathrm{~kg} / \mathrm{m}^{3}\end{array}$ & 0,75 \\
\hline
\end{tabular}

A concentração de cloretos em pontos no domínio é calculada considerando um total de 386 pontos internos. Para cada um dos três níveis de agressividade ambiental adotados, 10000 simulações de Monte Carlo foram realizadas. A probabilidade de despassivação é calculada para cada um dos pontos internos e, finalmente, seus valores são interpolados, obtendo curvas isoprobabilísticas de despassivação.

As curvas de isoprobabilidade para os três níveis de agressividade ambiental considerados, para 25 e 50 anos de exposição a cloretos, estão representadas nas figuras a seguir.

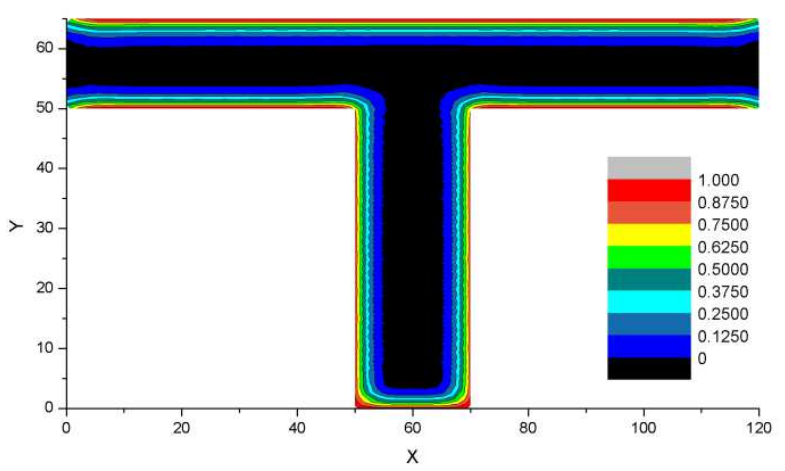

(a)

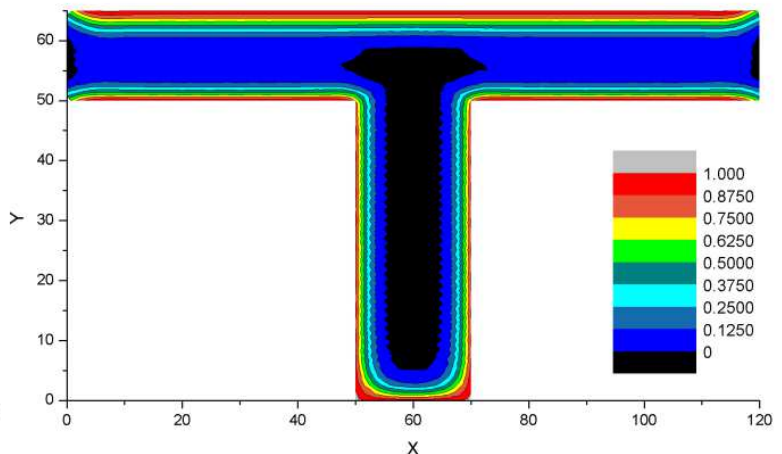

(b)

Figura 3.16 - Exemplo 2: curvas de isoprobabilidade para tempos de despassivação iguais a 25 (a) e 50 (b) anos: agressividade ambiental normal

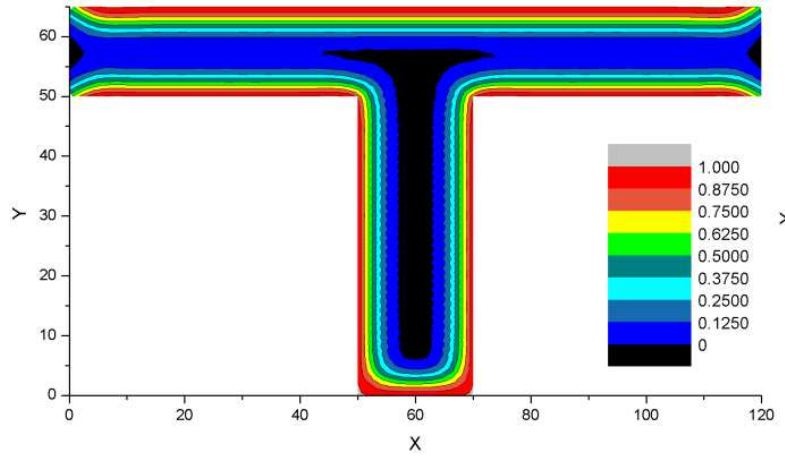

(a)

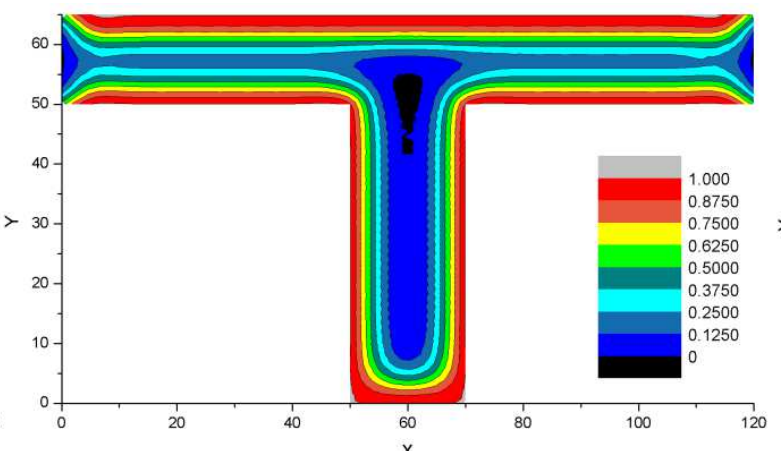

(b)

Figura 3.17 - Exemplo 2: curvas de isoprobabilidade para tempos de despassivação iguais a 25 (a) e 50 (b) anos: agressividade ambiental alta 


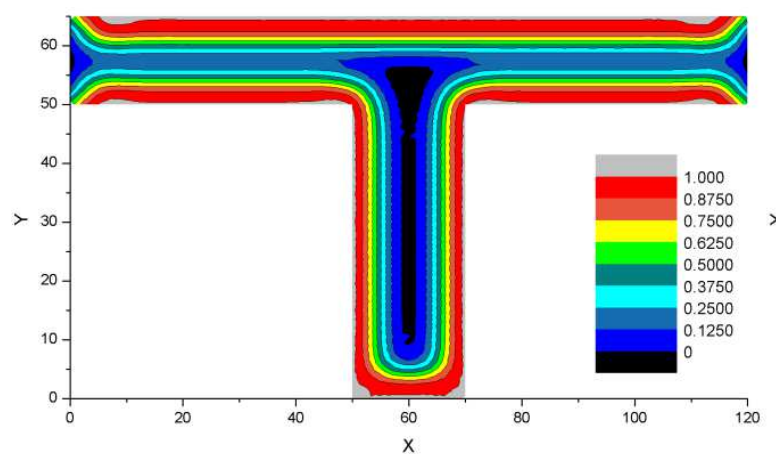

(a)

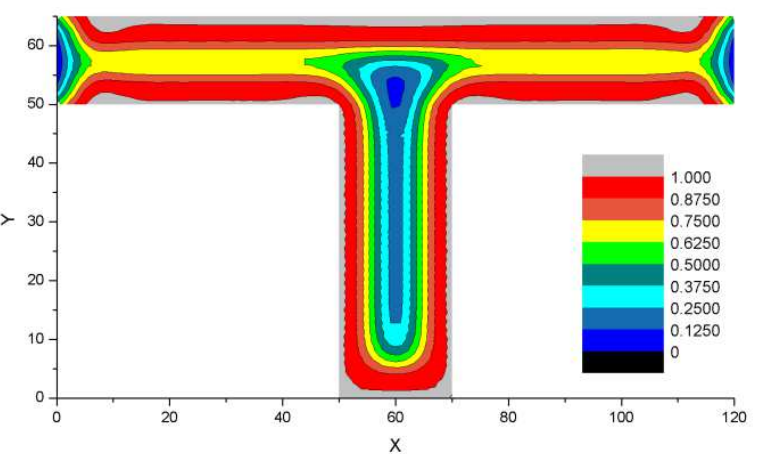

(b)

Figura 3.18 - Exemplo 2: curvas de isoprobabilidade para tempos de despassivação iguais a 25 (a) e 50 (b) anos: agressividade ambiental extrema

Como esperado, as curvas de isoprobabilidade possuem valores maiores em pontos próximos ao contorno e decrescem conforme avançam para o interior do domínio. É possível notar claramente a grande influência do nível de agressividade ambiental na resposta para o mesmo tempo de despassivação. Outro efeito observado é que as curvas de isoprobabilidade próximas à face superior da seção transversal avançam mais rapidamente que as demais, uma vez que nessa face a concentração superficial de cloretos é mais alta que nas demais faces. As respostas obtidas em zonas próximas as faces laterais da laje, onde o fluxo é imposto igual a zero como condição de contorno, não é significante e pode ser desprezada.

Uma análise de convergência no cálculo da probabilidade de despassivação foi feita a fim de assegurar uma resposta confiável. Na maioria dos pontos internos, a convergência da probabilidade de despassivação aconteceu com nem metade do número total de simulações. Evidentemente, em pontos onde a probabilidade é baixa (menor que 1\%), um grande número de simulações seria necessário para uma estimativa da probabilidade de despassivação. Contudo, pelo fato de ser um problema onde as probabilidades são altas para um considerável número de pontos no domínio, calcular valores pequenos de probabilidade para outros pontos não é de interesse, uma vez que a despassivação já ocorrida em pontos com altos valores de probabilidade ocasionaria problemas no comportamento mecânico da seção transversal de concreto armado.

A fim de observar em maiores detalhes a evolução das curvas de isoprobabilidade, análises adicionais foram feitas enriquecendo o domínio com pontos internos em áreas específicas da seção transversal, para uma interpolação mais precisa dos valores de probabilidade. Três áreas em particular foram escolhidas, conforme pode ser visto na Figura 3.19. A primeira área, próxima ao vértice $A$, com 196 pontos internos. A segunda área, próxima ao vértice $H$, com 192 pontos internos. A última área, pertencente à laje, com 196 pontos internos. As coordenadas 
das áreas e as curvas de isoprobabilidade estão ilustradas nas Figuras 3.20, 3.21 e 3.22. Todas estas análises foram feitas considerando apenas o nível de agressividade ambiental normal.

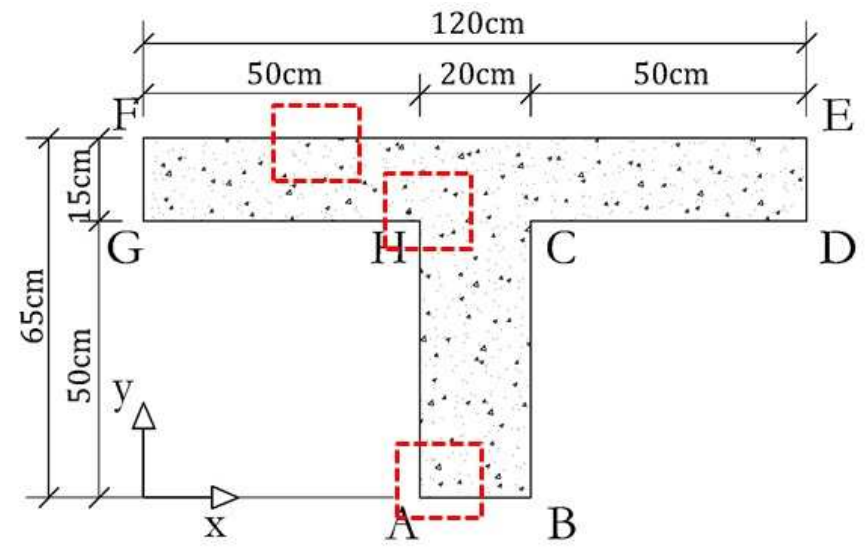

Figura 3.19 - Exemplo 2: localização das áreas específicas para determinação das curvas de isoprobabilidade

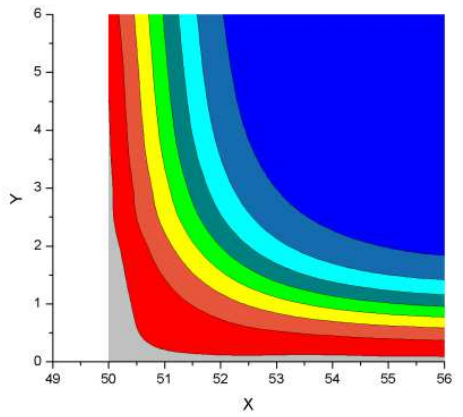

(a)

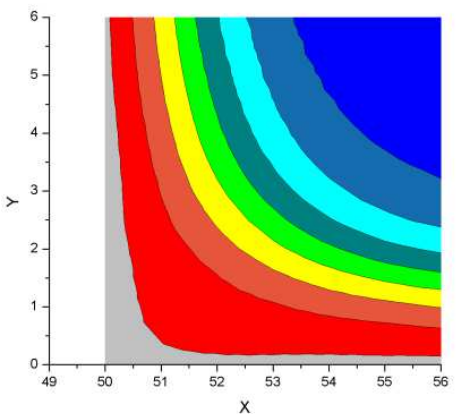

(b)

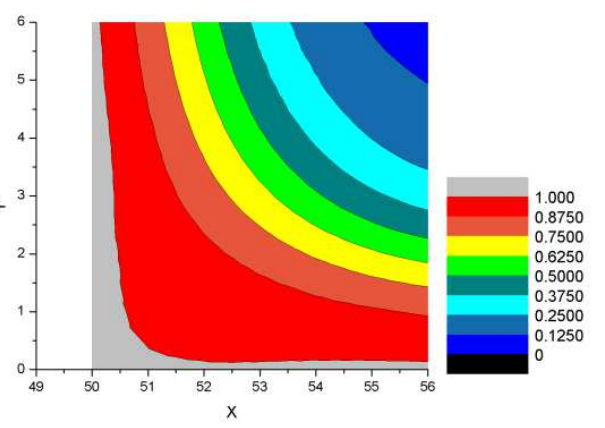

(c)

Figura 3.20 - Exemplo 2: curvas de isoprobabilidade para tempos de despassivação iguais a 25 (a), 50 (b) e 75 (c) anos para agressividade ambiental normal: área próxima ao vértice $\mathrm{A}$

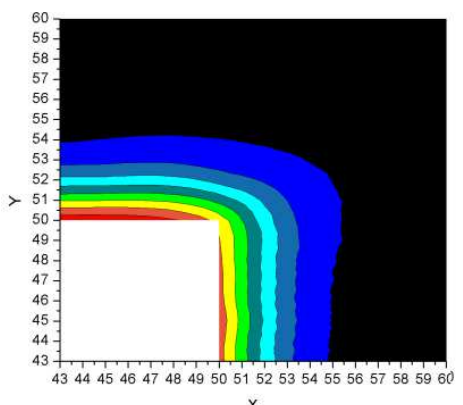

(a)

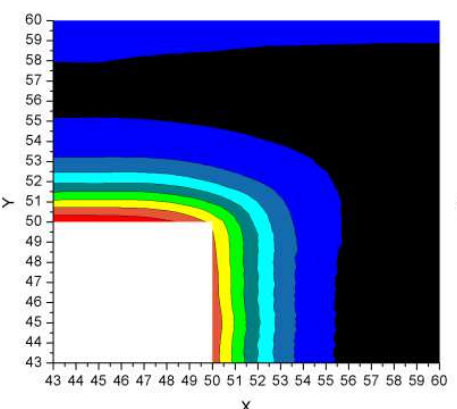

(b)

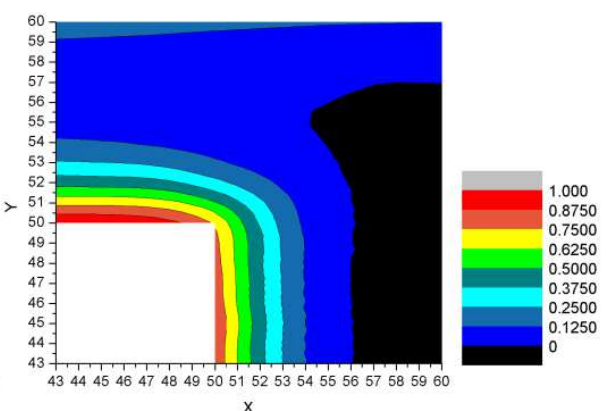

(c)

Figura 3.21 - Exemplo 2: curvas de isoprobabilidade para tempos de despassivação iguais a 25 (a), 50 (b) e 75 (c) anos para agressividade ambiental normal: área próxima ao vértice $\mathrm{H}$ 


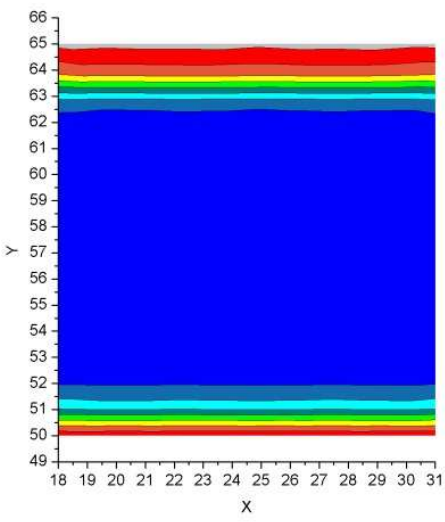

(a)

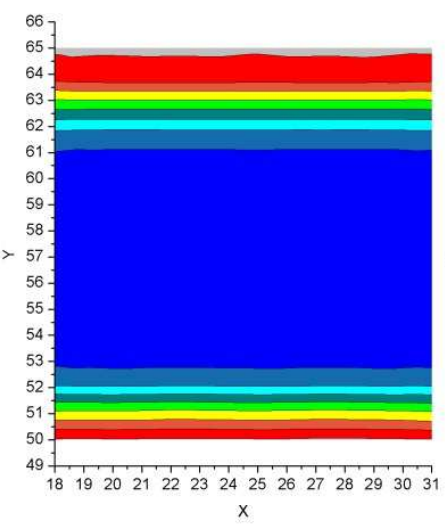

(b)

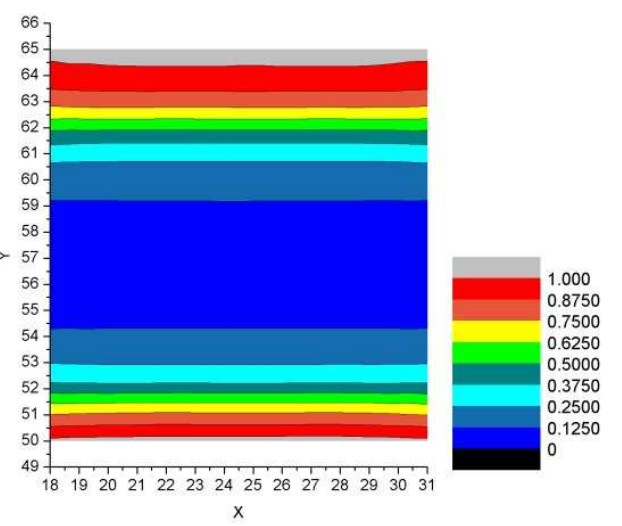

(c)

Figura 3.22 - Exemplo 2: curvas de isoprobabilidade para tempos de despassivação iguais a 25 (a), 50 (b) e 75 (c) anos para agressividade ambiental normal: área da laje

Comportamentos distintos de evolução das curvas de isoprobabilidade para as três áreas da seção transversal podem ser notados. Essa distinção na evolução pode ser compreendida a partir das condições de contorno de cada área, assim como a partir da geometria do domínio onde o processo de difusão ocorre.

Os resultados obtidos para a área próxima ao vértice A, ilustrados na Figura 3.19, revelam um rápido avanço das curvas de isoprobabilidade para o interior do domínio. As probabilidades de despassivação são bastante distintas para pequenas diferenças de espessura de cobrimento. Por exemplo, as probabilidades de despassivação após 50 anos de exposição a cloretos para uma espessura de concreto de 1 a $5 \mathrm{~cm}$ em x e y são, respectivamente iguais a $0,9737,0,8378,0,4120$, 0,1646 e 0,0745 . O rápido avanço das curvas de isoprobabilidade nessa área ocorre especialmente porque o processo de difusão ocorre de maneira considerável em duas direções.

Por outro lado, a velocidade da evolução das curvas de isoprobabilidade na área próxima ao vértice $\mathrm{H}$ é bastante distinta. É possível notar uma pequena mudança no posicionamento das curvas de isoprobabilidade com o avanço do tempo, conforme mostrado na Figura 3.20. Essa mudança é muito menor do que aquela observada na área próxima ao vértice $A$, apesar de ambas as áreas terem a mesma concentração média de cloretos nas faces externas. A diferença comportamental ocorre porque a área de difusão, apesar de ocorrer em duas direções, é predominantemente unidirecional.

Finalmente, na área pertencente a laje, as curvas de isoprobabilidade avançam mais rapidamente do que nas demais áreas, conforme ilustrado na Figura 3.21. A difusão neste caso é predominantemente unidirecional, porém ocorre em dois sentidos: de cima para baixo e viceversa. Nesta área é possível notar também que as probabilidades de despassivação são bem diferentes para pequenas diferenças de cobrimento de concreto. 
Neste exemplo ilustrou-se que os históricos de evolução das probabilidades de despassivação em distintas áreas de uma mesma seção transversal podem ser muito diferentes. Pode acontecer que algumas armaduras sejam mais suscetíveis a despassivação do que outras, dependendo das condições de contorno do problema. Assim, a importância do controle do cobrimento das barras em elementos de concreto armado é evidenciada, uma vez que pequenas mudanças no posicionamento das barras na seção transversal podem causar grandes mudanças nos valores de probabilidade de despassivação. 


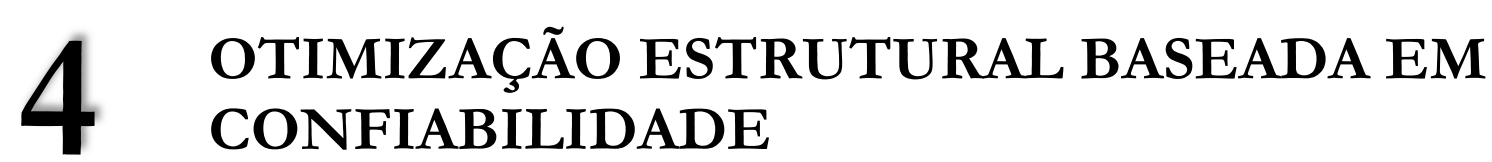

\subsection{Considerações iniciais}

A otimização é algo que é praticado cotidianamente e historicamente pela humanidade. Desde a criação da roda para minimizar o esforço físico no transporte a escolha da menor (ou mais ágil) fila no supermercado, temos sempre um desejo intrínseco de buscar a melhor solução para os problemas que enfrentamos. Em um contexto de engenharia não é diferente. Os desenvolvimentos e projetos devem ser o produto resultante de um processo que tenha por objetivo melhorar ao máximo a qualidade de vida das pessoas. Evidentemente, nesse processo, o tempo e os materiais disponíveis são finitos. Logo, existe uma grande necessidade de utilizar tais recursos da melhor maneira possível.

Os problemas que a engenharia procura resolver possuem natureza complexa. Projetar um motor com uma maximização da eficiência a combustão, definir a melhor disposição geométrica de um produto para seu armazenamento e comercialização, minimizar estrategicamente a necessidade de reparos em turbinas hidrelétricas e maximizar a vida útil de uma ponte de concreto armado são exemplos de tarefas relacionadas a uma investigação pela melhor forma de aplicação de recursos. A racionalização desse processo de busca pode ser feita por meio de ferramentas de otimização.

Os processos de análise e projeto, em sua maioria, envolvem a utilização de funções matemáticas para a descrição do comportamento de componentes e sistemas. Logo, as técnicas de otimização para maximização/minimização de parâmetros podem ser utilizadas para a busca de valores extremos dessas funções. Geralmente, tais técnicas envolvem repetidas e sistemáticas avaliações da resposta dos sistemas por meio de uma modelagem computacional. Uma vez que se chega a um projeto teoricamente ótimo, protótipos reais podem ser testados a fim de verificar o seu desempenho.

Alguns benefícios e inconvenientes da otimização feita por meio de um procedimento numérico são elencados por Vanderplaats (1999). Dentre as vantagens desse procedimento temse:

- Redução do tempo de elaboração de projetos, especialmente se um mesmo programa computacional puder ser aplicado a vários problemas;

- Sistematização lógica do processo de projetação; 
- Possibilidade de englobar uma grande variedade de variáveis de projeto e restrições, o que pode ser complicado em métodos gráficos ou por meio de tabelas;

- Teoricamente conduz a melhorias no projeto;

- Não sofre com a tendenciosidade da intuição ou experiência, tendo assim potencial de gerar melhorias ou projetos não tradicionais;

- Requer uma mínima interação entre homem e máquina.

Dentre as limitações e cuidados do processo de otimização numérico destaca-se:

- Aumento do custo computacional conforme o número de variáveis de projeto aumenta, podendo tornar os métodos numericamente mal condicionados ou o tempo de processamento proibitivo;

- Ausência de experiência ou intuição nas técnicas, sendo assim limitado ao alcance da aplicabilidade dos programas de análise;

- Pode gerar resultados enganosos caso o programa de análise não for teoricamente preciso;

- Lentidão ou até impossibilidade de convergência caso o problema for altamente não linear;

- Raramente pode assegurar a obtenção de um ótimo global sem a reinicialização do processo considerando diferentes pontos iniciais;

- Dificuldades de adaptação de códigos computacionais existentes, uma vez que muitos programas não foram desenvolvidos pensando em um acoplamento com algoritmos de otimização.

Outro ponto de interesse relacionado a otimização refere-se a sua interação com as incertezas presentes nos problemas. A forma com que a probabilidade de falha pode afetar configurações de projeto, as potenciais consequências econômicas de uma falha e como custos esperados do ciclo de vida estrutural podem ser incorporados no procedimento de projeto são relevantes exemplos de aplicação de processos numéricos de otimização.

Neste capítulo são apresentados os conceitos e aspectos fundamentais envolvidos nos processos de otimização, bem como os algoritmos utilizados para a otimização sob incertezas do cobrimento de seções transversais de concreto armado sujeitas a difusão de íons cloreto. Acoplamentos de processos de otimização com uma solução analítica e com o modelo em elementos de contorno, apresentado no capítulo 2, são ilustrados por meio de exemplos de aplicação. Para maiores detalhes sobre otimização recomenda-se a consulta dos seguintes autores: Fox (1973), Luenberger (1984), Vanderplaats (1999), Nocedal e Wright (2006), Rao (2009) e Arora (2017). 


\subsection{Conceitos fundamentais}

Neste tópico são discutidos alguns conceitos fundamentais em problemas de otimização como mínimo global, mínimo local, condições necessárias e condições suficientes, ponto viável, restrições ativas e inativas, dentre outros. Tais conceitos são fundamentais para o entendimento e formulação dos métodos de otimização estrutural.

\subsubsection{Formulação matemática geral para problemas de otimização estrutural}

Em um problema de otimização tem-se as seguintes funções e variáveis:

- Função objetivo $f$ : é uma função usada para a definição da configuração ou projeto ótimo. Para cada possível configuração/projeto, $f$ retorna um número que indica quão bom é este projeto. Em problemas de minimização busca-se o menor valor que $f$ pode assumir e em problemas de maximização o maior valor. Essa função pode medir o peso, deslocamento, tensão efetiva, área da seção transversal, custo de produção, espessura de cobrimento do concreto, etc.

- Vetor de variáveis de projeto $\boldsymbol{d}$ : vetor que contém as variáveis de projeto, que são os parâmetros do problema cujos valores mudam ao longo do processo de otimização a fim de se encontrar seu valor ótimo, representado por $\boldsymbol{d}^{*}$. O vetor $\boldsymbol{d}$ é manipulado pela função objetivo e pelo processo de otimização.

- Vetor de variáveis de estado $\boldsymbol{y}$ : vetor que contém as variáveis que descrevem o comportamento estrutural, sendo que seus valores são o resultado direto do modelo de análise estrutural utilizado e indireto do processo de otimização. O vetor $\boldsymbol{y}$ pode, ou não, ser manipulado pela função objetivo.

Assim, um problema de otimização estrutural genérico pode ser formulado da seguinte maneira:

\section{Encontrar: $\boldsymbol{d}^{*}$}

Que minimiza (ou maximiza): $f(\boldsymbol{d}, \boldsymbol{y})$

Sujeito a: $\left\{\begin{array}{l}\text { restrições de comportamento em } \boldsymbol{y} \\ \text { restrições de projeto em } \boldsymbol{d}\end{array}\right.$

Para manter a notação compacta, considera-se no texto que $\boldsymbol{d}$ englobe tanto variáveis de projeto quanto variáveis de estado. Distinções entre esses dois tipos de variáveis são feitas quando oportuno. Além disso, como a maior parte dos problemas de otimização estrutural envolve a minimização da função objetivo, a palavra "maximização" não é explicitada na formulação, embora os conceitos e algoritmos que são apresentados possam ser igualmente utilizados nesse tipo de problema. 
Assim, um problema de otimização estrutural pode ser escrito explicitando-se as restrições da seguinte maneira:

\section{Encontrar: $\boldsymbol{d}^{*}$}

Que minimiza: $f(\boldsymbol{d})$

Sujeito a: $\left\{\begin{array}{l}H_{i}(\boldsymbol{d})=0, i=1, \ldots, p \\ G_{j}(\boldsymbol{d}) \leq 0, j=1, \ldots, m \\ \boldsymbol{d} \in S \subset \mathbb{R}^{n_{d}}\end{array}\right.$

em que $H_{i}(\boldsymbol{d})$ são funções de restrição de igualdade, $G_{j}(\boldsymbol{d})$ são funções de restrição de desigualdade, $S$ é o domínio admissível de projeto, i.e., um conjunto de valores que $\boldsymbol{d}$ pode assumir (por exemplo, $S=\left[\boldsymbol{d}_{\boldsymbol{m} \boldsymbol{n} \boldsymbol{n}}, \boldsymbol{d}_{\boldsymbol{m} \text { áx }}\right]$ ), também chamadas de restrições laterais, $p$ é o número de restrições de igualdade, $m$ é o número de restrições de desigualdade e $n_{d}$ é o número de variáveis de projeto.

Os algoritmos numéricos para resolver problemas de otimização, como aquele descrito pela Equação (4.2), podem ser classificados em dois grandes grupos: algoritmos de programação matemática e métodos heurísticos. A programação matemática inclui o método de descida mais íngreme (steepest descent), gradientes conjugados, gradientes reduzidos generalizados, método golden section, método de Newton e quase Newton, simplex, programação linear sequencial SLP (acrônimo em inglês para Sequential Linear Programming), programação quadrática sequencial SQP (acrônimo em inglês para Sequential Quadratic Programming), método da penalização exterior, método da penalização interior e o método das direções factíveis. Já dentre os métodos heurísticos tem-se os algoritmos genéticos, têmpera simulada, pesquisa de vizinhança variável, pesquisa local iterada, pesquisa tabu, entre outros. É importante destacar que os problemas tratados pela Equação (4.2) consideram apenas uma única função objetivo a ser minimizada. Para duas ou mais funções objetivo tem-se um problema de otimização multiobjectivo, fugindo do escopo do presente trabalho.

\subsubsection{Ponto viável, domínio viável, restrições ativas e inativas}

Um ponto (ou configuração) viável é aquele que satisfaz todas as restrições existentes num problema de otimização. O conjunto de todos os pontos que satisfazem essas mesmas restrições é chamado de domínio viável.

Restrições de desigualdade definem uma fronteira entre um domínio viável e outro inviável. Se um ponto se encontra exatamente na fronteira, tem-se uma restrição ativa. Se o ponto se encontra no domínio viável, tem-se uma restrição inativa. Se o ponto não satisfaz uma dada restrição, tem-se uma restrição violada. Dentro do domínio viável, restrições de igualdade 
$H_{i}(\boldsymbol{d})=0$ são sempre ativas e restrições de desigualdade são ativas quando $G_{j}(\boldsymbol{d})=0$ e inativas quando $G_{j}(\boldsymbol{d})<0$.

\subsubsection{Mínimo global}

Uma função $f(\boldsymbol{x})$ com $n$ variáveis possui um mínimo global em $\boldsymbol{x}^{*}$, também chamado de mínimo absoluto, se o valor da função $f$ avaliada em $\boldsymbol{x}^{*}$ for menor ou igual ao valor da função $f$ avaliada em qualquer outra configuração $\boldsymbol{x}$ pertencente ao domínio de valores que satisfazem as restrições do problema. Assim:

$f\left(\boldsymbol{x}^{*}\right) \leq f(\boldsymbol{x})$

Se a desigualdade estrita for válida para todo $\boldsymbol{x}$ exceto para $\boldsymbol{x}^{*}$, ou seja, se $f\left(\boldsymbol{x}^{*}\right)<f(\boldsymbol{x})$, tem-se um mínimo global forte, também denominado de mínimo global estrito ou isolado. Caso contrário, tem-se um mínimo global fraco.

\subsubsection{Mínimo local}

Uma função $f(\boldsymbol{x})$ com $n$ variáveis possui um mínimo local em $\boldsymbol{x}^{*}$, também chamado de mínimo relativo, se a Equação (4.3) for válida para todo $\boldsymbol{x}$ em uma pequena proximidade $N$ de $\boldsymbol{x}^{*}$ pertencente ao domínio de valores que satisfazem as restrições do problema. Se em $N$ for verificada a condição $f\left(\boldsymbol{x}^{*}\right)<f(\boldsymbol{x})$, tem-se um mínimo local forte. Caso contrário, tem-se um mínimo local fraco. A Figura (4.1) ilustra os conceitos de mínimos locais e global para uma função de uma variável num intervalo de $a$ a $b$.

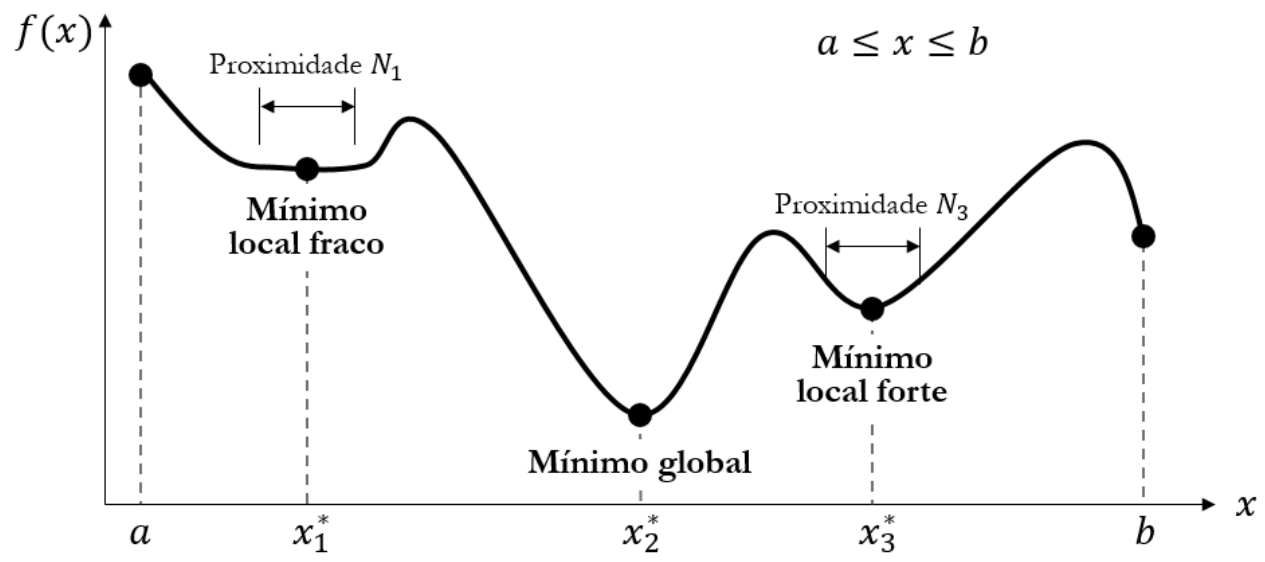

Figura 4.1 - Mínimos locais e global para uma função de uma variável

\subsubsection{Condições necessárias e suficientes de otimalidade}

Em matemática os termos "condições necessárias" e "condições suficientes" são frequentemente utilizados. Contudo, as definições e discussões aqui feitas estão inseridas num contexto de otimização. As condições de otimalidade servem de diretrizes pela busca da 
configuração ótima. Além disso, devem ser verificadas para garantir que uma configuração é de fato ótima. Essas condições envolvem o estudo do comportamento das funções objetivo e suas derivadas.

Condições que devem ser satisfeitas na configuração ótima são chamadas necessárias. Caso tais condições não sejam satisfeitas, a configuração em questão não pode ser ótima. Contudo, se tais condições forem satisfeitas, a configuração em questão pode ainda não ser ótima, ou seja, existem configurações não ótimas que satisfazem essas mesmas condições. As condições necessárias de primeira e segunda ordem envolvem as derivadas parciais de primeira e segunda ordem da função objetivo, respectivamente.

Condições suficientes são aquelas que, se forem satisfeitas, garantem que a configuração é de fato ótima. Se as condições suficientes não forem satisfeitas ou não puderem ser usadas, não é possível concluir nada a respeito da otimalidade de uma dada configuração. As condições suficientes envolvem derivadas parciais de segunda ordem e de ordens superiores da função objetivo.

\subsubsection{Condições necessárias e suficientes para mínimos locais em problemas sem restrições}

A condição necessária de primeira ordem é que a função $f(\boldsymbol{x}) \operatorname{com} n$ variáveis possui um mínimo local em $\boldsymbol{x}^{*}$ se:

$\frac{\partial f\left(\boldsymbol{x}^{*}\right)}{\partial x_{i}}=0, i=1$ a $n$

A condição necessária de segunda ordem é que a função $f(\boldsymbol{x})$ possui um mínimo local em $\boldsymbol{x}^{*}$ se sua matriz Hessiana $\overline{\boldsymbol{H}}\left(\boldsymbol{x}^{*}\right)$

$\overline{\boldsymbol{H}}\left(\boldsymbol{x}^{*}\right)=\left[\frac{\partial^{2} f}{\partial x_{i} \partial x_{j}}\right]_{(n \times n)}=\left[\begin{array}{cccc}\frac{\partial^{2} f}{\partial x_{1}^{2}} & \frac{\partial^{2} f}{\partial x_{1} \partial x_{2}} & \cdots & \frac{\partial^{2} f}{\partial x_{1} \partial x_{n}} \\ \frac{\partial^{2} f}{\partial x_{2} \partial x_{1}} & \frac{\partial^{2} f}{\partial x_{2}^{2}} & \cdots & \frac{\partial^{2} f}{\partial x_{2} \partial x_{n}} \\ \vdots & \vdots & \ddots & \vdots \\ \frac{\partial^{2} f}{\partial x_{n} \partial x_{1}} & \frac{\partial^{2} f}{\partial x_{n} \partial x_{2}} & \cdots & \frac{\partial^{2} f}{\partial x_{n}^{2}}\end{array}\right]$

for positiva semi-definida ou positiva definida no ponto $\boldsymbol{x}^{*}$. Uma matriz é positiva definida quando todos os seus autovalores são positivos e é positiva semi-definida quando todos os seus autovalores são não negativos. 
A condição suficiente de segunda ordem é que se a matriz Hessiana for positiva definida em um ponto estacionário $\boldsymbol{x}^{*}$, então $\boldsymbol{x}^{*}$ é um ponto de mínimo local para a função $f(x)$. Um ponto $\boldsymbol{x}^{*}$ é estacionário se obedecer a Equação (4.4).

As condições acima descritas se aplicam a problemas de otimização sem restrições. Contudo, estas mesmas condições fazem parte de um conjunto maior de condições para problemas de otimização com restrições.

\subsubsection{Condições necessárias e suficientes para mínimos locais em problemas com restrições}

Um problema de otimização que possui formato igual ao da Equação (4.2) pode ser resolvido por meio de aplicação das condições necessárias de primeira ordem de Karush-KuhnTucker (KKT). Seja $\boldsymbol{x}^{*}$ um ponto regular ${ }^{3}$ de um domínio viável que é um mínimo local de $f(\boldsymbol{x})$, sujeito a $H_{i}(\boldsymbol{x})=0, i=1$ a $p ; G_{j}(\boldsymbol{x}) \leq 0, j=1$ a $m$. Existem multiplicadores de Lagrange $\boldsymbol{v}^{*}$ (vetor de tamanho $p$ ) e $\boldsymbol{u}^{*}$ (vetor de tamanho $m$ ) de forma que a função Lagrangeana é estacionária com relação a $x_{j}, v_{i}, u_{j}$ e $s_{j}$ no ponto $\boldsymbol{x}^{*}$. A variável $s$ é uma variável de folga que transforma restrições de desigualdade em restrições de igualdade. As condições de KKT podem ser verificadas conforme (ARORA, 2017):

1. A função Lagrangeana do problema é escrita da seguinte forma:

$$
\begin{aligned}
\mathcal{L}(\boldsymbol{x}, \boldsymbol{v}, \boldsymbol{u}, \boldsymbol{s})=f(\boldsymbol{x})+\sum_{i=1}^{p} v_{i} \bar{H}_{i}(\boldsymbol{x})+\sum_{j=1}^{m} u_{j}\left(G_{j}(\boldsymbol{x})+s_{j}^{2}\right)= \\
=f(\boldsymbol{x})+\boldsymbol{v}^{T} \overline{\boldsymbol{H}}(\boldsymbol{x})+\boldsymbol{u}^{T}\left(\boldsymbol{G}(\boldsymbol{x})+\boldsymbol{s}^{2}\right)
\end{aligned}
$$

2. Condições de gradientes:

$$
\begin{aligned}
& \frac{\partial \mathcal{L}}{\partial x_{k}}=\frac{\partial f}{\partial x_{k}}+\sum_{i=1}^{p} v_{1}^{*} \frac{\partial \bar{H}_{i}}{\partial x_{k}}+\sum_{j=1}^{m} u_{j}^{*} \frac{\partial G_{j}}{\partial x_{k}}=0, k=1 \text { a } n \\
& \frac{\partial \mathcal{L}}{\partial v_{i}}=0 \rightarrow \bar{H}_{i}\left(\boldsymbol{x}^{*}\right)=0 \quad, i=1 \text { a } p \\
& \frac{\partial \mathcal{L}}{\partial u_{j}}=0 \rightarrow G_{j}(\boldsymbol{x})+s_{j}^{2}=0 \quad, j=1 \text { a } m
\end{aligned}
$$

3. Verificação da viabilidade de desigualdades: $s_{j}^{2} \geq 0$ ou equivalentemente $G_{j} \leq 0, j=1$ a $m$

4. Condições de comutação:

\footnotetext{
${ }^{3}$ Um ponto é chamado de "regular" de um domínio viável se a função objetivo for contínua e os gradientes de todas as restrições ativas forem linearmente independentes naquele ponto.
} 
$\frac{\partial \mathcal{L}}{\partial s_{j}}=0 \rightarrow 2 u_{j}^{*} s_{j}=0 \quad, j=1$ a $m$

5. Não negatividade dos multiplicadores de Lagrange para desigualdades:

$u_{j}^{*} \geq 0, j=1$ a $m$

6. Verificação de regularidade: os gradientes das restrições ativas devem ser linearmente independentes. Nesse caso, os multiplicadores de Lagrange para as restrições são únicos.

A aplicação das condições de KKT resulta geralmente em um sistema não linear de equações que pode ser facilmente resolvido por meio de métodos numéricos. Uma grande variedade de softwares possui ferramentas que permitem a solução de tais sistemas. Outros softwares possuem já funções de minimização que incluem a aplicação das condições de KKT. Para mais detalhes recomenda-se consultar o livro de Arora (2017).

\subsection{Otimização sob incertezas}

\subsubsection{Aspectos gerais}

Um problema de otimização sob incertezas considera a presença de aleatoriedade nos parâmetros envolvidos num problema de otimização determinístico. O objetivo é encontrar o conjunto de valores $\boldsymbol{d}^{*}=\left[d_{1}, d_{2}, \ldots, d_{n}\right]$ que resulte numa configuração ótima e que satisfaça restrições em confiabilidade. Essas restrições podem ser escritas de duas formas: em termos da probabilidade de falha, de forma que a probabilidade de falha da configuração ótima seja menor

que a probabilidade de falha alvo $\left(P_{f_{\text {ótima }}}<P_{f_{T}}\right)$ ou; em termos do índice de confiabilidade, de forma que o índice de confiabilidade da configuração ótima seja maior do que o índice de confiabilidade alvo $\left(\beta_{\text {ótimo }}>\beta_{T}\right)$. As incertezas das variáveis podem ser introduzidas na função objetivo, nas restrições de igualdade, de desigualdade e laterias.

Soluções analíticas fechadas para problemas de otimização sob incertezas são possíveis de serem obtidas para um reduzido número de casos particulares, sendo que tais casos possuem aspectos mais acadêmicos do que práticos. $\mathrm{Na}$ maior parte dos problemas são necessárias soluções envolvendo processo iterativos, em que a função objetivo e a probabilidade de falha são calculadas repetidas vezes até que se atinja convergência. Consequentemente, na solução iterativa de um problema de otimização, um problema de confiabilidade precisa ser resolvido a cada iteração. Como o problema de confiabilidade requer a avaliação da equação de estado limite que define o respectivo modo de falha, um grande número de chamadas do modelo de resposta estrutural se faz necessário. Assim, as diversas estratégias utilizadas para a solução de problemas 
de otimização sob incertezas apresentam maneiras sistemáticas para a interação entre a busca pela configuração ótima e as restrições probabilísticas.

Em problemas de otimização sob incertezas é importante saber diferenciar os tipos de variáveis envolvidas, pois cada método possui um funcionamento próprio para o tratamento de cada tipo de variável. O vetor $\boldsymbol{d}$ pode conter tanto variáveis de projeto aleatórias quanto variáveis de projeto determinísticas. As variáveis de projeto aleatórias são descritas pelas distribuições de probabilidade das variáveis aleatórias que representam, sendo que os processos de otimização, em geral, buscam valores ótimos para as médias dessas variáveis. Variáveis ditas "puramente aleatórias" $\boldsymbol{X}$ (não de projeto) também podem fazer parte do problema, sendo tratadas como variáveis de estado.

Os domínios de falha e de segurança em problemas de otimização sob incertezas são definidos de maneira análoga aos mesmos domínios para problemas de confiabilidade. Uma falha (estado indesejado) é caracterizada quando a equação de estado limite $G(\boldsymbol{X}, \boldsymbol{d})$ resultar em um valor negativo. Já a segurança (estado desejado) é caracterizada quando $G(\boldsymbol{X}, \boldsymbol{d})$ resultar em um valor positivo. Quando $G(\boldsymbol{X}, \boldsymbol{d})$ resultar igual a zero, tem-se a fronteira entre os domínios de falha e segurança. Tais domínios são representados por:

$\Omega_{f}=\{\boldsymbol{x}, \boldsymbol{d} \mid G(\boldsymbol{X}, \boldsymbol{d})<0\}$

$\Omega_{s}=\{\boldsymbol{x}, \boldsymbol{d} \mid G(\boldsymbol{X}, \boldsymbol{d})>0\}$

O domínio de falha $\Omega_{f}$ contém todos os valores assumidos pelas variáveis de projeto $\boldsymbol{d}$ (determinísticas e/ou aleatórias), aleatórias $\boldsymbol{X}$ e de estado que resultam em um estado estrutural indesejado. O domínio de segurança $\Omega_{s}$ contém os valores complementares àqueles do domínio de falha, ou seja, valores que resultam em um estado estrutural de não falha.

A Equação (4.13) está escrita considerando somente um modo de falha, ou seja, apenas uma equação de estado limite. No caso de duas ou mais equações de estado limite, $\Omega_{f}$ e $\Omega_{s}$ são definidos conforme o tipo de associação entre os diversos modos de falha estrutural: associação em série, em paralelo ou mista.

Existem diversas formas de formular problemas de otimização estrutural sob incertezas. Nos próximos tópicos estão descritos os aspectos gerais de cada um destes tipos de problema.

\subsubsection{Otimização determinística}

A otimização determinística, também chamada de abordagem de projeto determinista DDO (acrônimo em inglês para Deterministic Design Optimization) não engloba explicitamente as incertezas presentes nas variáveis. Tais incertezas são consideradas indiretamente por meio de 
fatores parciais de segurança. Um problema de otimização determinístico genérico pode ser formulado da seguinte maneira:

\section{Encontrar: $\boldsymbol{d}^{*}$}

Que minimiza: $f(\boldsymbol{d})$

Sujeito a: $\left\{\begin{array}{l}\sum_{i=1}^{n} \gamma_{R_{i}} R_{i} \geq \sum_{j=1}^{m} \gamma_{L_{j}} L_{j} \\ \boldsymbol{d} \in S \subset \mathbb{R}^{n_{d}}\end{array}\right.$

em que $R_{i}$ descreve a capacidade estrutural, como tensão máxima resistente, tensão de escoamento, deslocamento máximo permitido, etc., $L_{j}$ descreve a resposta estrutural frente a uma solicitação, $\gamma_{R_{i}}$ e $\gamma_{L_{j}}$ são, respectivamente, os fatores parciais de segurança da capacidade estrutural e da resposta estrutural e $S$ é o domínio admissível de projeto, tendo dimensão igual ao número de variáveis de projeto $n_{d}$.

Apesar da abordagem por meio dos fatores de segurança ter apresentado melhorias com relação a abordagem por meio de estados limites, a não consideração explícita do efeito das incertezas das variáveis pode resultar em um desnecessário excesso de segurança (com maiores custos de execução, por exemplo) ou em sua carência (com elevados custos esperados de falha, por exemplo). Os fatores de segurança compensam incompreensões, suposições e simplificações existentes durante a fase de projeto e análise.

Nas normas de projeto convencionais, os parâmetros de projeto são determinados com relação ao modo de falha com menor margem de segurança. Contudo, se existirem outros modos de falha totalmente ou parcialmente dependentes das mesmas variáveis, que possam apresentar maiores margens de segurança individuais, um processo de otimização determinístico será incapaz de quantificar essa sobra de segurança nos demais modos de falha. Dessa forma, pode ocorrer que os parâmetros de projeto resultem superdimensionados.

Outro exemplo de limitação da formulação DDO diz respeito a sua aplicação a uma estrutura hiperestática, onde alguns membros estruturais pouco solicitados podem ter seus parâmetros de projeto de resistência reduzidos ou podem até mesmo virem a ser removidos da estrutura pelo processo de otimização. Contudo, se as incertezas fossem consideradas, probabilidades de falha para tais membros removidos poderiam se tornar relevantes. Assim, o que pode ocorrer é que o processo de otimização determinístico resulte em parâmetros de projeto subdimensionados. Além disso, alterações de comportamento estrutural, constatados num processo de colapso progressivo (perda sucessiva de graus hiperestáticos), influenciam fortemente o processo de otimização e são difíceis de serem considerados em uma formulação DDO. Uma abordagem por meio da confiabilidade de sistemas facilita o processo de otimização em tais casos. 


\subsubsection{Otimização robusta}

A otimização robusta RO (acrônimo em inglês para Robust Optimization), também conhecida como otimização estocástica, é uma abordagem que leva em consideração as incertezas presentes nas variáveis. O objetivo desse processo de otimização é de obter uma configuração de projeto que seja o menos sensível possível as incertezas. Um problema de RO genérico pode ser formulado da seguinte maneira:

Encontrar: $\boldsymbol{d}^{*}$

Que minimiza: $f(\boldsymbol{d})$

Sujeito a: $\left\{\begin{array}{l}H_{i}\left(\boldsymbol{a}_{\boldsymbol{H}_{\boldsymbol{i}}}, \boldsymbol{d}\right)=0, i=1, \ldots, p \\ G_{j}\left(\boldsymbol{a}_{\boldsymbol{G}_{j}}, \boldsymbol{d}\right) \leq 0, j=1, \ldots, m \\ \boldsymbol{d} \in S \subset \mathbb{R}^{n_{d}}, \boldsymbol{a}_{\boldsymbol{H}_{\boldsymbol{i}}} \in A_{H} \subset \mathbb{R}^{p}, \boldsymbol{a}_{\boldsymbol{G}_{\boldsymbol{j}}} \in A_{G} \subset \mathbb{R}^{m}\end{array}\right.$

em que $\boldsymbol{a}_{\boldsymbol{H}_{\boldsymbol{i}}}$ e $\boldsymbol{a}_{\boldsymbol{G}_{\boldsymbol{j}}}$ são, respectivamente, vetores de perturbação (ou parâmetros de incerteza) das variáveis contidas nas restrições de igualdade e desigualdade e $A_{H}$ e $A_{G}$ são os respectivos conjuntos de incertezas possíveis, geralmente sendo conjuntos fechados.

$\mathrm{Na}$ formulação de um problema de RO é possível também considerar a presença de incertezas que afetam a função objetivo $f$. Isso normalmente é feito introduzindo-se um vetor de perturbação para essa função.

Apesar desta formulação introduzir um conjunto de incertezas que define a permissividade de variabilidade, problemas de RO não envolvem o cálculo de probabilidades de falha. Consequentemente, não é possível garantir um dado nível de segurança estrutural à configuração otimizada.

\subsubsection{Otimização baseada em confiabilidade}

A otimização baseada em confiabilidade RBDO (acrônimo em inglês para Reliability Based Design Optimization) é um tipo de problema de otimização em que são impostas restrições em função de parâmetros confiabilísticos. Um problema RBDO usual pode ser formulado da seguinte maneira:

\section{Encontrar: $\boldsymbol{d}^{*}$}

Que minimiza: $f(\boldsymbol{d})$

Sujeito a: $\left\{\begin{array}{l}P_{f_{i}}(\boldsymbol{d}) \leq P_{f_{T_{i}}}, i=1, \ldots, n_{L S} \\ \boldsymbol{d} \in S \subset \mathbb{R}^{n_{d}}\end{array}\right.$ 
em que $P_{f_{i}}(\boldsymbol{d})$ é a probabilidade de falha de um modo de falha $i, P_{f_{T_{i}}}$ é a probabilidade de falha alvo do modo de falha $i$ e $n_{L S}$ é o número de estados limites do problema. Uma forma alternativa de formular o problema é a seguinte:

Encontrar: $\boldsymbol{d}^{*}$

Que minimiza: $f(\boldsymbol{d})$

Sujeito a: $\left\{\begin{array}{l}\beta_{i}(\boldsymbol{d}) \geq \beta_{T_{i}}, \quad i=1, \ldots, n_{L S} \\ \boldsymbol{d} \in S \subset \mathbb{R}^{n_{d}}\end{array}\right.$

em que $\beta_{i}(\boldsymbol{d})$ é o índice de confiabilidade de um modo de falha $i$ e $\beta_{T_{i}}$ é o índice de confiabilidade alvo do modo de falha $i$. As Equações (4.16) e (4.17) podem também conter restrições de igualdade e desigualdade envolvendo variáveis de projeto, como consta na Equação (4.2). Além disso, para problemas envolvendo a confiabilidade de sistemas é possível reescrever as Equações (4.16) e (4.17) considerando probabilidades de falha e índices de confiabilidade para o sistema. Restrições probabilísticas dos modos de falha individuais podem também coexistir com as restrições probabilísticas de falha do sistema. Contudo, esse tipo de formulação foge do escopo do presente trabalho e não é aqui abordada.

\subsubsection{Otimização do custo do ciclo de vida e do risco}

A otimização do custo do ciclo de vida e do risco LCRO (acrônimo em inglês para LifeCycle and Risk. Optimization) é um tipo de abordagem de otimização estrutural mais abrangente. As probabilidades de falha são incluídas a fim de se quantificar os potenciais custos envolvidos de falha. Além disso, os demais custos envolvidos ao longo de todo o ciclo de vida estrutural podem ser considerados no processo de otimização. Um problema LCRO usual pode ser formulado da seguinte forma:

\section{Encontrar: $\boldsymbol{d}^{*}$}

Que minimiza: $C_{E T}(\boldsymbol{d})$

Sujeito a: $\left\{\begin{array}{l}P_{f_{i}}(\boldsymbol{d}) \leq P_{f_{T_{i}}}, i=1, \ldots, n_{L S} \\ \boldsymbol{d} \in S \subset \mathbb{R}^{n_{d}}\end{array}\right.$

em que $C_{E T}(\boldsymbol{d})$ é o custo esperado total do ciclo de vida da estrutura. A função objetivo do problema é $C_{E T}(\boldsymbol{d})$, sendo este uma composição de outros custos, conforme:

$C_{E T}(\boldsymbol{d})=C_{C}(\boldsymbol{d})+C_{O}(\boldsymbol{d})+C_{I \& M}(\boldsymbol{d})+C_{E F}(\boldsymbol{d})$

em que $C_{C}(\boldsymbol{d}), C_{O}(\boldsymbol{d}), C_{I \& M}(\boldsymbol{d})$ e $C_{E F}(\boldsymbol{d})$ são, respectivamente, os custos de construção, operação, inspeção e manutenção e os custos esperados de falha, sendo estes últimos definidos conforme: 
$C_{E F}(\boldsymbol{d})=\sum_{i=1}^{n_{L S}} C_{f_{i}}(\boldsymbol{d}) P_{f_{i}}(\boldsymbol{d})$

em que $C_{f_{i}}(\boldsymbol{d})$ é o custo de falha associado ao modo de falha $i$. É importante destacar que, neste tipo de problema, a probabilidade de falha está inserida dentro da função objetivo, o que não ocorre nos outros tipos de formulação. Outro ponto a ser destacado se refere a relação entre $C_{f_{i}}(\boldsymbol{d})$ e $P_{f_{i}}(\boldsymbol{d})$, podendo assumir um comportamento fortemente não linear caso, por exemplo, se considere a influência do tempo e de taxas econômicas no cálculo de $C_{f_{i}}(\boldsymbol{d})$.

A grande vantagem da abordagem LCRO é que ela é capaz de buscar uma relação ótima entre custos, segurança e a configuração das variáveis de projeto. Essa relação é ilustrada na Figura (4.2):

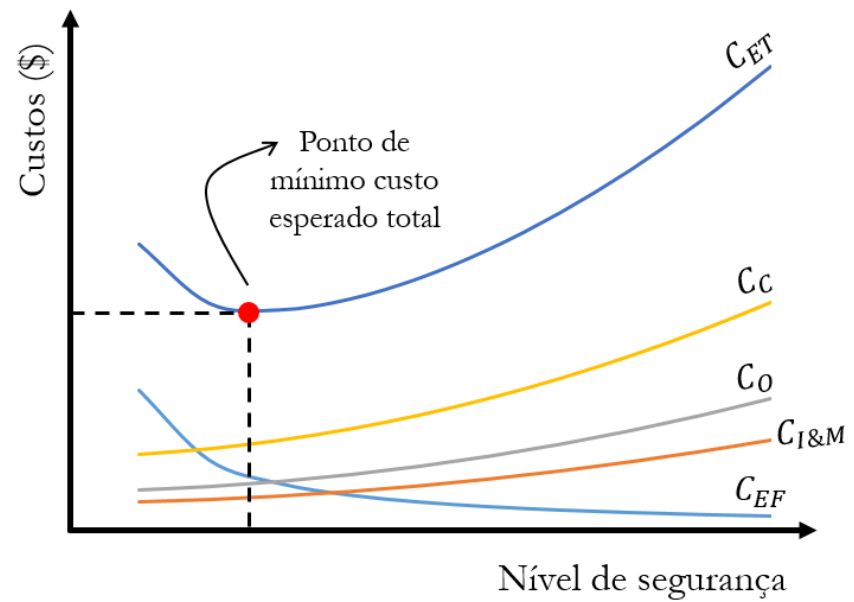

Figura 4.2 - Relação entre custos envolvidos e nível de segurança

A abordagem LCRO começou a ser explorada no início dos anos 2000. Contudo, até o presente momento, as formulações e publicações sobre este assunto são orientadas à resolução de problemas específicos. Além disso, estudos envolvendo LCRO adotam geralmente modelos de previsão de comportamento estrutural bastante simplificados. Uma formulação mais abrangente, bem como algoritmos mais gerais se fazem necessários, sendo esta uma potencial área de desenvolvimento científico no campo da otimização.

\subsubsection{Potencialidades e limitações das diferentes abordagens de otimização}

Análises do tipo DDO consideram as incertezas indiretamente por meio de fatores de segurança e abordagens $\mathrm{RO}$ incorporam as incertezas por meio de variáveis de perturbação que definem a permissividade de variabilidades. Porém, tanto a DDO quanto a RO não incluem o cálculo de probabilidades de falha em sua formulação. Abordagens do tipo RBDO consideram diretamente o efeito das incertezas das variáveis no processo de otimização, garantindo que um 
dado nível mínimo de segurança seja alcançado. Por fim, abordagens do tipo LCRO abrangem custos esperados de falha, que são influenciados pelas probabilidades de falha, bem como custos envolvidos ao longo de todo o ciclo de vida estrutural.

$\mathrm{Na}$ Tabela (4.1) estão apresentadas as potencialidades e limitações de cada tipo de abordagem de otimização estrutural.

Tabela 4.1 - Potencialidades e limitações dos diferentes tipos de abordagens de otimização
Tipo de abordagem
Potencialidades
Limitações

\begin{tabular}{ccc}
\hline \hline Otimização determinística (DDO) & Abordagem mais simples & $\begin{array}{c}\text { Incapaz de garantir um nível de } \\
\text { segurança preestabelecido e não } \\
\text { inclui variabilidade dos parâmetros }\end{array}$ \\
\hline Otimização robusta (RO) & Inclui variabilidade dos parâmetros & $\begin{array}{c}\text { Incapaz de garantir um nível de } \\
\text { segurança preestabelecido }\end{array}$ \\
\hline $\begin{array}{c}\text { Otimização baseada em } \\
\text { confiabilidade (RBDO) }\end{array}$ & $\begin{array}{c}\text { Garante que um nível de segurança } \\
\text { mínimo seja alcançado por meio de } \\
\text { restrições na probabilidade de falha }\end{array}$ & $\begin{array}{c}\text { Incapaz de incluir custos esperados } \\
\text { de falha }\end{array}$ \\
\hline $\begin{array}{c}\text { Otimização do custo do ciclo de } \\
\text { vida e do risco (LCRO) }\end{array}$ & $\begin{array}{c}\text { Inclui custos esperados de falha, } \\
\text { custos do ciclo de vida e } \\
\text { probabilidades de falha }\end{array}$ & $\begin{array}{c}\text { Poucas formulações disponíveis na } \\
\text { literatura, sendo um problema mais } \\
\text { complexo de ser resolvido }\end{array}$ \\
\hline
\end{tabular}

Um estudo comparativo entre as formulações DDO, RBDO e LCRO é apresentado por Beck e Gomes (2012), envolvendo problemas simples com equações de estado limite analíticas. Os autores argumentam que a forma distinta com que as abordagens são formuladas conduz a resultados diferentes para problemas semelhantes. Além disso, para os problemas estudados, se configurações otimizadas obtidas por abordagens DDO ou RBDO forem utilizadas como dados de entrada em uma abordagem LCRO, o resultado final pode ser diferente daquele obtido diretamente via uma abordagem LCRO.

\subsection{Solução de problemas RBDO}

Os problemas de otimização da presente tese são do tipo RBDO, uma vez que tal abordagem é capaz de considerar adequadamente as incertezas presentes no problema. A formulação de um problema RBDO, conforme consta na Equação (4.16) ou (4.17), envolve a avaliação da probabilidade de falha $P_{f}$ ou do índice de confiabilidade $\beta$, respectivamente. As primeiras metodologias para a solução de problemas RBDO empregavam uma abordagem de laço duplo, i.e., um laço interno para a análise de $P_{f}$ ou $\beta$ e um laço externo com o processo de otimização do problema. Tal metodologia é ilustrada na Figura (4.3): 


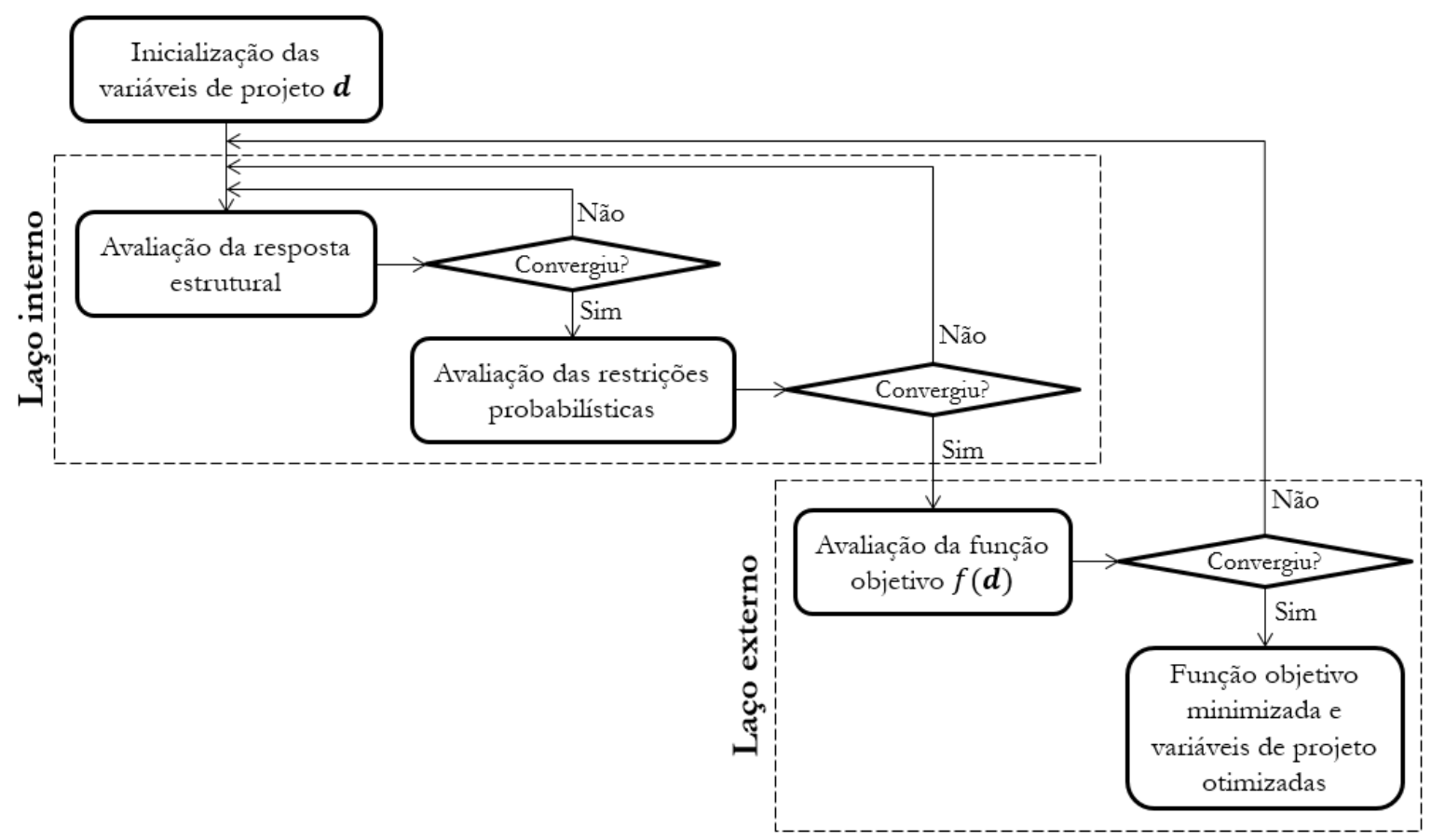

Figura 4.3 - Abordagem de laço duplo em problemas RBDO

Os primeiros algoritmos para a solução de problemas RBDO foram baseados no FORM. Nesta abordagem, no laço interno, a probabilidade de falha é calculada por meio da equação:

$P_{f}(\boldsymbol{d})=P[G(\boldsymbol{X}, \boldsymbol{d}) \leq 0]=F_{G}(0)=\int_{G(\boldsymbol{X}, \boldsymbol{d}) \leq 0} f_{\boldsymbol{X}}(\boldsymbol{x}) d \boldsymbol{x} \approx \Phi(-\beta)$

em que $F_{G}($. ) é a função de distribuição acumulada descrita por um dado modo de falha. A partir da Equação (4.21) o problema RBDO pode ser abordado de duas maneiras distintas.

$\mathrm{Na}$ abordagem pelo índice de confiabilidade RIA (acrônimo em inglês para Reliability Index Approach), o problema de otimização é formulado com restrições impostas ao índice de confiabilidade, conforme:

\section{Encontrar: $\boldsymbol{d}_{\boldsymbol{R} I \boldsymbol{A}}^{*}$}

Que minimiza: $f(\boldsymbol{d})$

Sujeito a: $\left\{\begin{array}{l}\beta=\left\{-\Phi^{-1}\left[F_{G}(0)\right]\right\} \geq \beta_{T} \\ \boldsymbol{d} \in S \subset \mathbb{R}^{n_{d}}\end{array}\right.$

Já na abordagem de medida de desempenho PMA (acrônimo em inglês para Performance Measure Approach), o problema de otimização é formulado com restrições impostas a equação de estado limite (conhecida também como função de desempenho) conforme:

\section{Encontrar: $\boldsymbol{d}_{\boldsymbol{P M A}}^{*}$}

Que minimiza: $f(\boldsymbol{d})$

Sujeito a: $\left\{\begin{array}{l}G(\boldsymbol{X}, \boldsymbol{d})=\left\{F_{G}^{-1}[\Phi(-\beta)]\right\} \geq 0 \\ \boldsymbol{d} \in S \subset \mathbb{R}^{n_{d}}\end{array}\right.$ 
Na RIA busca-se encontrar $\boldsymbol{d}_{\boldsymbol{R} I \boldsymbol{A}}^{*}$, que é conhecido como "ponto de projeto" ou "ponto mais provável", sendo este o ponto com maior conteúdo de probabilidades no domínio de falha. Na PMA busca-se encontrar $\boldsymbol{d}_{\boldsymbol{P} \boldsymbol{M} \boldsymbol{A}}^{*}$, que é conhecido como "ponto de mínimo desempenho" na hiperesfera de confiabilidade alvo. As duas abordagens convergem para a mesma resposta quando as restrições estiverem ativas.

Apesar da RIA e da PMA aparentarem certa equivalência, as duas abordagens apresentam notáveis diferenças. A RIA contém restrições que envolvem a avalição do índice de confiabilidade, o que é uma tarefa mais complexa de ser realizada do que as restrições da PMA, que envolvem a avaliação da equação de estado limite. A PMA é mais eficiente do que a RIA para restrições inativas e também apresenta uma maior taxa de convergência (YOUN et al., 2003; TU et al., 1999).

Apesar da PMA ser mais atrativa do que a RIA, sua aplicação direta dentro de uma abordagem de laço duplo pode ser comprometida em termos computacionais para certos problemas. Abordagens de laço único, que desacoplam os laços interno e externo, tornando-os um único laço, se apresentam como uma alternativa mais eficiente. Dois algoritmos adotando este tipo de abordagem, utilizados no presente trabalho, são especificados nos próximos tópicos.

\subsection{Abordagem de laço único}

As abordagens de laço único em problemas RBDO procuram obter simultaneamente a configuração de projeto otimizada e a confiabilidade alvo dentro de um mesmo laço de otimização. Os primeiros pesquisadores seguindo esta abordagem utilizaram a RIA, o que pode tornar o problema mal condicionado, apresentando instabilidades e até ineficiência. Em pesquisas seguintes, procurando resolver tais problemáticas, foram apresentadas metodologias que substituíram o laço de confiabilidade interno por condições de primeira ordem KKT em uma abordagem PMA. Contudo, até então, todas as abordagens introduziam variáveis normais como variáveis de projeto adicionais na formulação, aumentando significativamente a dimensão e o custo computacional envolvidos no problema.

Neste panorama se insere o trabalho de Liang et al. (2004). A abordagem de laço único SLA (acrônimo em inglês para Single Loop Approach) consiste em impor as condições KKT dos laços de confiabilidade como restrições determinísticas de igualdade equivalentes no laço de otimização. Dessa forma, o problema de otimização probabilístico é convertido em um problema determinístico equivalente, tornando desnecessário o cálculo repetido do ponto de mínimo desempenho nos laços de confiabilidade.

O algoritmo proposto por Liang et al. (2004) está ilustrado na Figura (4.4). 


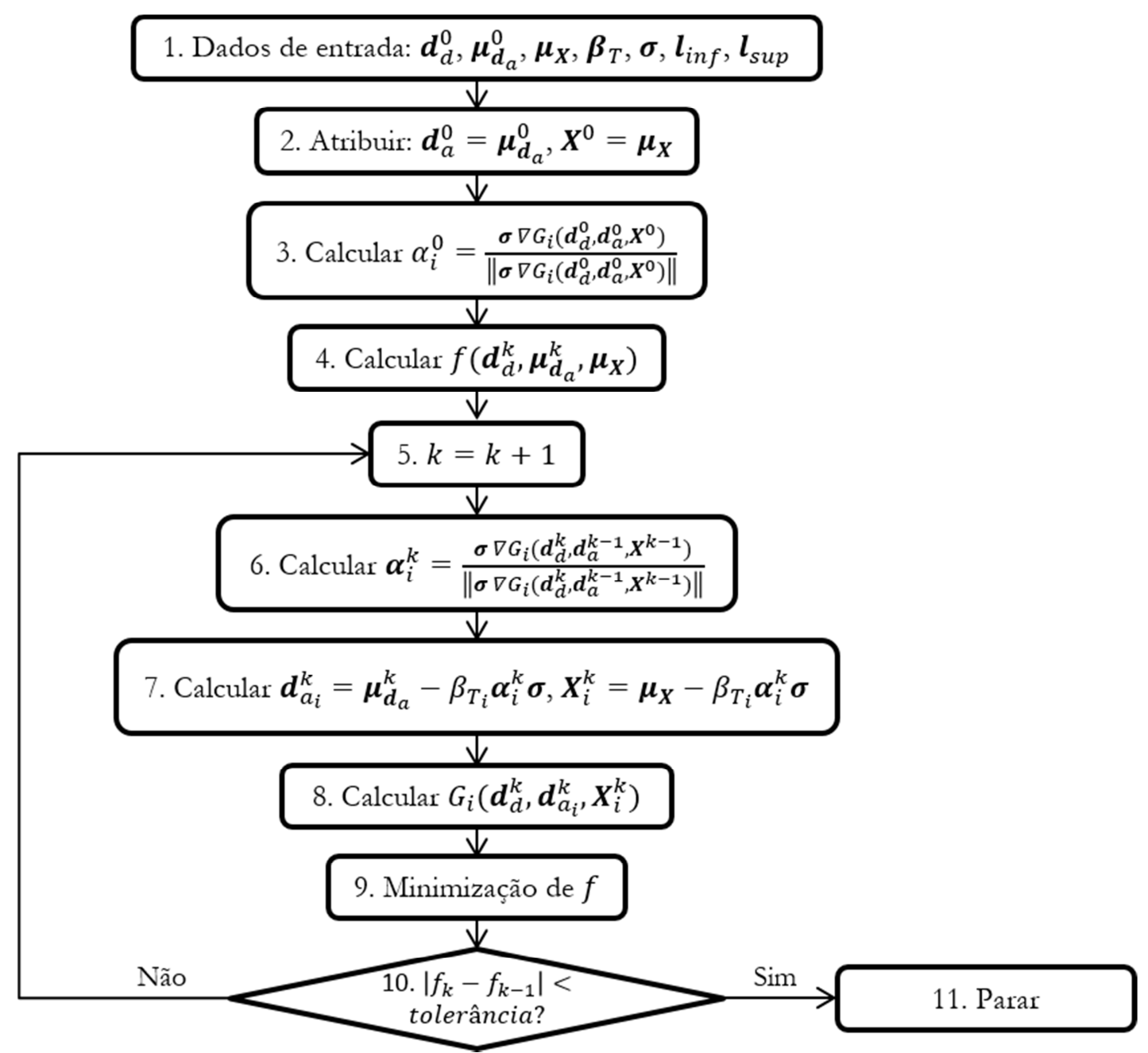

Figura 4.4 - Abordagem de laço único SLA.

Fonte: Adaptado de Liang et al. (2004)

O vetor $\boldsymbol{d}_{d}$ contém as variáveis de projeto determinísticas, $\boldsymbol{d}_{\boldsymbol{a}}$ as variáveis de projeto aleatórias, $\boldsymbol{X}$ as variáveis aleatórias, $\boldsymbol{\sigma}$ o desvio padrão das variáveis, $\boldsymbol{\mu}_{\boldsymbol{d}_{a}}$ a média das variáveis de $\boldsymbol{d}_{a}, \boldsymbol{\mu}_{\boldsymbol{X}}$ a média das variáveis de $\boldsymbol{X}, \boldsymbol{\beta}_{T}$ contém o índice de confiabilidade alvo de cada modo de falha $i, \boldsymbol{l}_{\text {inf }}$ e $\boldsymbol{l}_{\text {sup }}$ são, respectivamente, os vetores contendo os limites inferiores e superiores das variáveis de projeto (aleatórias e determinísticas), $\boldsymbol{\alpha}$ é um vetor gradiente normalizado e $k$ é o contador da iteração de otimização.

No passo 9 da Figura 4.4, a função objetivo $f$ é minimizada por meio de um outro algoritmo. Como resultado, essa minimização resulta em novos valores em $\boldsymbol{\mu}_{\boldsymbol{d}_{\boldsymbol{a}}}$ e $\boldsymbol{\mu}_{\boldsymbol{X}}$. No caso deste trabalho, utilizou-se o algoritmo SQP (Sequential Quadratic Programming), sendo este um minimizador bastante conhecido e já disponível em boa parte dos softwares de álgebra computacional.

Outro ponto a destacar refere-se ao passo 7 da Figura 4.4, onde o ponto de mínimo desempenho é linearmente aproximado a cada iteração $k$. Caso as variáveis possuam distribuições 
não normais, é necessária uma transformação das mesmas em distribuições normais equivalentes. As duas condições envolvidas nesta transformação requerem que a função de distribuição acumulada $(\mathrm{CDF})$ e a função de densidade de probabilidade (PDF) das variáveis não normais e das variáveis normais equivalentes sejam iguais no atual ponto de mínimo desempenho.

Assim, no SLA, restrições equivalentes de otimização são adicionadas ao problema para remoção do laço de confiabilidade. A busca pela configuração ótima acontece paralelamente com restrições mutáveis que, iterativamente, convergem para o ponto de mínimo desempenho. O método é aproximado, robusto e pode não convergir em casos de funções altamente não lineares. Contudo, Aoues e Chateauneuf (2010) relatam que o SLA é superior em eficiência e robustez em comparação com diversos métodos de otimização. Trabalhos aplicando o SLA em problemas RBDO de sistemas podem ser consultados em Liang et al. (2007) e Nguyen et al. (2010).

\subsection{Método de simulação ponderada em problemas RBDO}

Um problema RBDO, descrito pela Equação (4.16) ou (4.17), pode ser resolvido também por métodos baseados em simulação. Esses métodos possuem um grande potencial de aplicação em problemas de resposta não linear e com variáveis aleatórias não normais, em contraste com os métodos de aproximação, que são adequados para problemas lineares e envolvendo variáveis aleatórias de distribuição normal. Contudo, uma grande desvantagem dos métodos de simulação consiste no elevado custo computacional atrelado.

Buscando aumentar a eficiência e precisão da avaliação das restrições probabilísticas de um problema RBDO, Rashki et al. (2014) apresentam uma estratégia que incorpora a análise de confiabilidade na etapa de otimização. Tal estratégia utiliza os conceitos de ponderação de amostras e flexibilidade de ponderação no cálculo da probabilidade de falha, conforme apresentado no trabalho de Rashki et al. (2012). O método de otimização consiste em gerar amostras uniformemente distribuídas no espaço de projeto que permitam obter configurações otimizadas realizando apenas um processo de simulação. Tal característica se articula muito bem com modelos de resposta estrutural complexa que, majoritariamente, possuem um tempo de processamento elevado.

\subsubsection{Ponderação de amostras no cálculo da probabilidade de falha}

O método de simulação ponderada WASM (acrônimo em inglês para Weighted Avarage Simulation Method), apresentado por Rashki et al. (2012), consiste em uma forma alternativa de cálculo da probabilidade de falha via simulação de Monte Carlo. O primeiro passo consiste em gerar $n_{\text {sim }}$ amostras uniformemente distribuídas, dentro de limites preestabelecidos, para cada 
uma das variáveis aleatórias. Em seguida, é calculado o peso $w_{i}$ de cada amostra $i$ por meio da multiplicação das funções de densidade de probabilidade $f_{j}($.$) de cada uma das n_{v \cdot a}$. variáveis aleatórias, conforme:

$w_{i}=\prod_{j=1}^{n_{v \cdot a}} f_{j}(i)$

A probabilidade de falha $P_{f}$ pode então ser calculada utilizando-se a função indicadora $I$ em cada amostra $i$, conforme se procede no método de simulação de Monte Carlo simples, porém o peso de cada amostra pondera a função $I$, conforme:

$P_{f}=\frac{\sum_{i=1}^{n_{\text {sim }}} I_{i} w_{i}}{\sum_{i=1}^{n_{\text {sim }}} w_{i}}$

Uma interessante potencialidade desta metodologia consiste em avaliar uma nova probabilidade de falha $P_{f}^{\prime}$ sem a necessidade de avaliar a função indicadora novamente. Se os parâmetros estatísticos e/ou o tipo de uma variável aleatória $j$ forem alternados, os pesos são recalculados conforme:

$w_{i}^{\prime}=\prod_{j=1}^{n_{\text {v.a. }}} f_{j}^{\prime}(i)$

A nova probabilidade de falha $P_{f}^{\prime}$ é então calculada conforme:

$P_{f}^{\prime}=\frac{\sum_{i=1}^{n_{\text {sim }}} I_{i} w_{i}^{\prime}}{\sum_{i=1}^{n_{\text {sim }}} w_{i}^{\prime}}$

A função indicadora permanece com seus valores constantes e não precisa ser reavaliada no cálculo da nova probabilidade de falha $P_{f}^{\prime}$, pois as amostras permanecem com os mesmos valores daqueles gerados no cálculo de $P_{f}$ na Equação (4.25). Cada vez que os pesos forem alterados em um dado problema, a nova probabilidade de falha pode ser obtida por meio dos novos pesos e da mesma função indicadora. Essa característica recebe o nome de "flexibilidade de ponderação" e é extremamente proveitosa em problemas que consomem um elevado tempo de processamento na avaliação da função indicadora. Essa vantagem se torna mais pronunciada quando empregada em conjunto com uma técnica de RBDO, conforme exposto a seguir.

\subsubsection{Acoplamento do WASM em problemas RBDO}

A metodologia para realizar uma análise RBDO utilizando o WASM é descrita por Rashki et al. (2014) em cinco etapas. Cada etapa é descrita a seguir. 
Etapa 1: geração de amostras uniformemente distribuídas para variáveis aleatórias no espaço de projeto

Independentemente do tipo de variável aleatória, são geradas amostras uniformemente distribuídas no espaço de projeto para cada variável aleatória do problema. Os limites superiores e inferiores de cada variável, para a geração de amostras com distribuição uniforme, são escolhidos em função do índice de confiabilidade estimado para o problema. Rashki et al. (2012) apresentam detalhes para a escolha desse intervalo de amostragem. Assim, um vetor de amostras $\boldsymbol{x}_{j}$ de uma variável aleatória $\boldsymbol{j}$ possuirá valores amostrais $x_{j, i}$, conforme:

$\boldsymbol{x}_{j}=\left\{x_{j, 1}, x_{j, 2}, \ldots, x_{j, i}, \ldots, x_{j, n_{s i m}}\right\}$

No caso de duas variáveis aleatórias, os vetores amostrais são:

$$
\begin{aligned}
& \boldsymbol{x}_{1}=\left\{x_{1,1}, x_{1,2}, \ldots, x_{1, i}, \ldots, x_{1, n_{\text {sim }}}\right\} \\
& \boldsymbol{x}_{2}=\left\{x_{2,1}, x_{2,2}, \ldots, x_{2, i}, \ldots, x_{2, n_{\text {sim }}}\right\}
\end{aligned}
$$

A distribuição das amostras da Equação (4.29) pode ser visualizada na Figura (4.5).

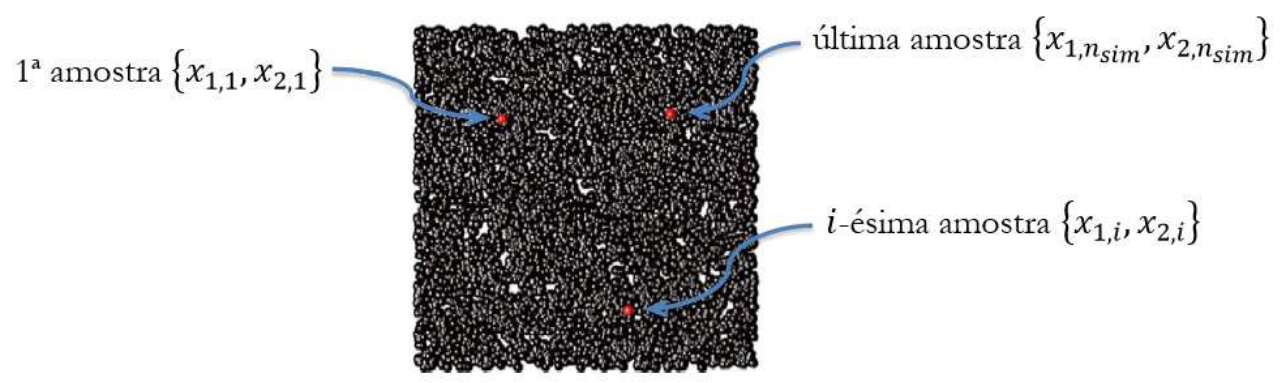

Figura 4.5 - Distribuição de amostras no espaço de projeto

Fonte: Adaptado de Rashki et al. (2014)

\section{Etapa 2: avaliação da função indicadora}

As amostras geradas na etapa 1 são empregadas na avaliação da equação de estado limite. Caso a equação de estado limite resulte em um valor negativo, a função indicadora valerá $1 \mathrm{e}$ identificará a amostra como sendo pertencente ao domínio de falha $\Omega_{f}$. Caso a equação de estado limite resulte em um valor positivo, a função indicadora valerá 0 e identificará a amostra como sendo pertencente ao domínio de segurança $\Omega_{s}$. Para uma equação de estado limite de formato circular de raio $R$, a Figura 4.6 ilustra a separação das amostras nos domínios de falha e de segurança. 


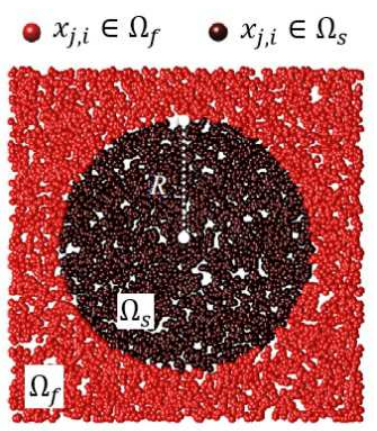

Figura 4.6 - Separação de amostras nos domínios de segurança e de falha Fonte: Adaptado de Rashki et al. (2014)

Etapa 3: cálculo da probabilidade de falha das amostras no domínio de segurança utilizando a $\underline{\text { característica de flexibilidade de ponderação }}$

Cada amostra pertencente ao domínio de segurança no espaço de projeto é uma potencial configuração ótima do problema RBDO. Para cada uma dessas amostras candidatas realiza-se o cálculo de sua probabilidade de falha por meio da Equação (4.27) considerando-se os valores da amostra como sendo iguais as médias de suas respectivas distribuições de probabilidades. Os pesos das amostras são recalculados conforme a Equação (4.26) cada vez que uma nova amostra candidata tiver sua probabilidade de falha avaliada. Dessa forma, com apenas um processo de avaliação da função indicadora, as probabilidades de falha associadas a todas as amostras pertencentes ao domínio de segurança podem ser estimadas. A ponderação das amostras no cálculo da $P_{f}$ é ilustrada na Figura (4.7).

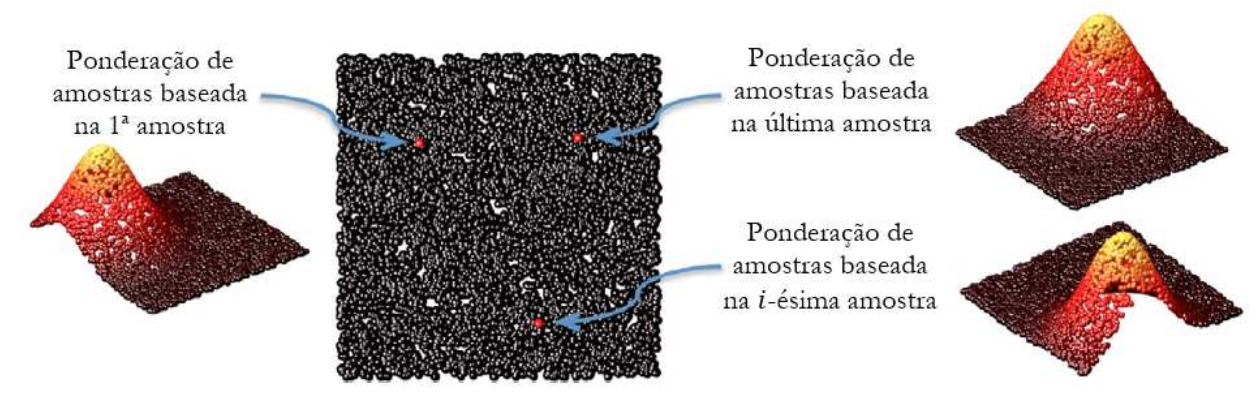

Figura 4.7 - Ponderação de amostras no cálculo da probabilidade de falha Fonte: Adaptado de Rashki et al. (2014)

Etapa 4: separação das amostras candidatas que satisfazem as restrições probabilísticas

Após o cálculo da $P_{f}$ de cada amostra pertencente ao domínio de segurança, são excluídas as amostras que possuem uma $P_{f}$ maior do que a $P_{f_{T}}$ especificada como restrição do problema. As amostras remanescentes pertencem a um domínio viável, chamado de domínio confiável, e a configuração ótima está localizada entre elas. A Figura (4.8) ilustra as amostras nos domínios de falha, segurança e confiável para uma equação de estado limite de formato circular no espaço de projeto. 


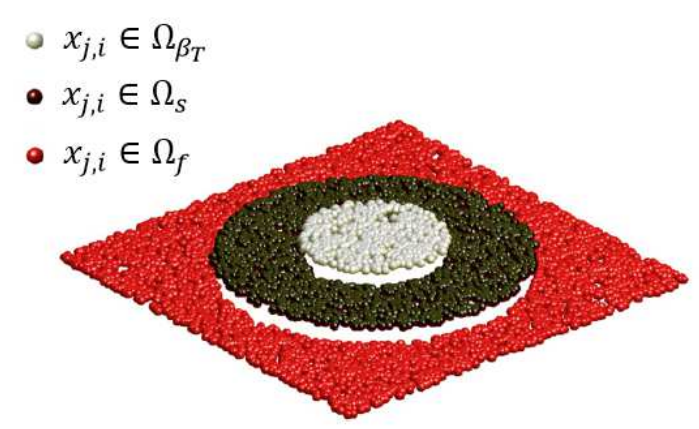

Figura 4.8 - Separação de amostras em um domínio confiável, de segurança e de falha Fonte: Adaptado de Rashki et al. (2014)

\section{Etapa 5: avaliação da função objetivo das amostras no domínio confiável}

Por fim, a função objetivo é avaliada para cada uma das amostras pertencentes ao domínio confiável, descrito na etapa 4. A amostra que resultar no menor valor da função objetivo é a amostra com os valores otimizados. Esta etapa é ilustrada na Figura (4.9).

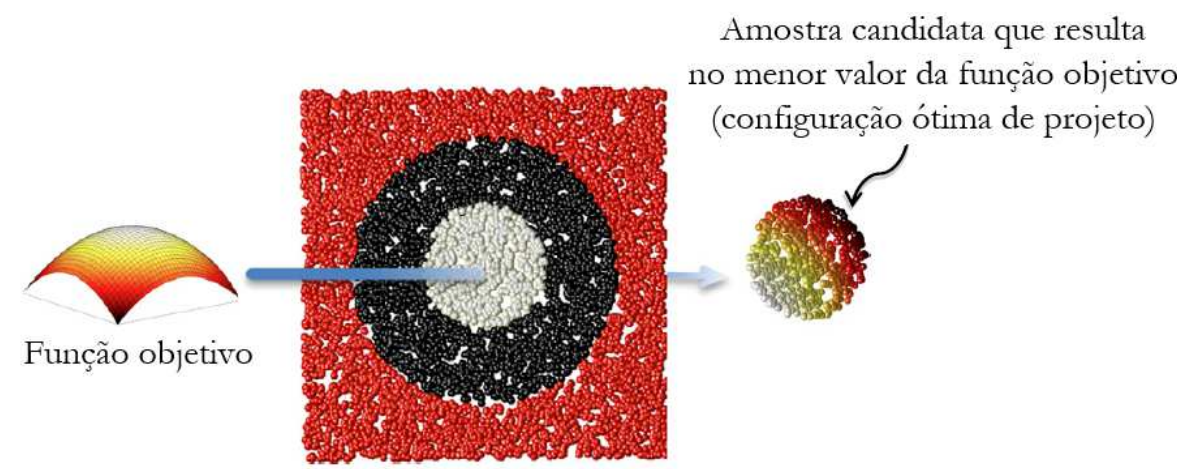

Figura 4.9 - Avaliação das amostras dentro do domínio confiável para determinação da configuração otimizada Fonte: Adaptado de Rashki et al. (2014)

\subsubsection{Vantagens e desvantagens do método}

As vantagens do método apresentado são:

1. Com apenas um processo de avaliação da função indicadora é possível obter múltiplas soluções de otimização variando-se, por exemplo: o índice de confiabilidade das restrições, a função objetivo e/ou a PDF das variáveis aleatórias;

2. O método não requer uma análise de sensibilidade ao se obter a solução ótima. Normalmente tais análises, necessárias em outras abordagens RBDO, apresentam problemas de convergência;

3. As variáveis aleatórias podem assumir qualquer tipo de distribuição de probabilidades e não são feitas transformações normais equivalentes sobre as mesmas, excluindo-se esse tipo de imprecisão;

4. O método permite obter a configuração ótima de múltiplos modos de falha de maneira simples. 
As limitações do método são:

1. Para problemas RBDO com muitas variáveis, o método requer um grande número de amostras para obter resultados precisos, o que pode torná-lo ineficiente;

2. O método considera problemas em que todas as variáveis de projeto são variáveis aleatórias. Assumir que variáveis de projeto determinísticas sejam variáveis com um pequeno coeficiente de variação conduz a uma solução conservadora.

\subsection{Exemplos de aplicação}

\subsubsection{Exemplo 1: SLA aplicado a $2^{\mathrm{a}}$ lei de Fick}

No presente exemplo busca-se otimizar o valor da espessura de cobrimento de um elemento de concreto submetido a penetração de íons cloreto. O problema RBDO formulado é resolvido por meio do algoritmo SLA (Single Loop Approach), apresentado na seção 4.5 da presente tese. Como o SLA envolve a avaliação do gradiente da equação de estado limite, neste exemplo optou-se por utilizar a lei de Fick como sendo o modelo difusivo.

A equação de estado limite que define o limiar entre a ocorrência ou não da despassivação é definida da seguinte forma:

$G=t_{\text {desp }}-t_{\text {v.u.p. }}$

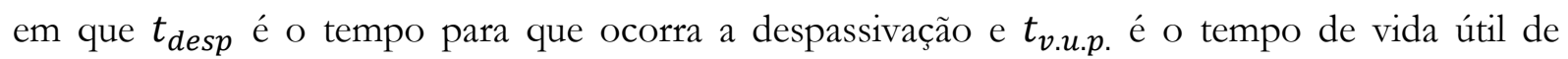
projeto. O tempo para ocorrência da despassivação é calculado por meio da lei de Fick, dada por:

$C(x, t)=C_{0} \operatorname{erfc}\left[\frac{x}{2 \sqrt{\kappa_{0} t}}\right]$

em que $C_{0}$ é a concentração de íons cloretos no contorno do domínio, $x$ é a distância em linha reta entre o contorno e um ponto no interior de um domínio semi-infinito, $\kappa_{0}$ é o coeficiente de difusão, $t$ é o tempo transcorrido do processo difusivo e erfc é a função matemática de valor complementar da função erro de Gauss. Para se calcular o tempo para que ocorra a despassivação em um determinado ponto $x$ basta assumir $C(x, t)$ como sendo igual a concentração limite de cloretos $C_{l i m}$ e isolar a variável $t$ dessa equação, obtendo-se:

$t_{\text {desp }}=\frac{1}{\kappa_{0}}\left[\frac{x}{2 \operatorname{erfc}^{-1}\left(\frac{C_{l i m}}{C_{0}}\right)}\right]^{2}$

em que $\operatorname{erfc}^{-1}$ é a inversa da função matemática de valor complementar da função erro de Gauss. Como neste exemplo é de interesse saber quando ocorrerá a despassivação em uma 
profundidade $x$ tal igual à espessura de cobrimento do concreto $c o b$, assume-se que $x=c o b$ na Equação (4.32), obtendo-se:

$t_{\text {desp }}=\frac{1}{\kappa_{0}}\left[\frac{c o b}{2 \operatorname{erfc}^{-1}\left(\frac{C_{\text {lim }}}{C_{0}}\right)}\right]^{2}$

Assim, a Equação (4.30) pode ser reescrita, conforme:

$G=\frac{1}{\kappa_{0}}\left[\frac{c o b}{2 \mathrm{erfc}^{-1}\left(\frac{C_{l i m}}{C_{0}}\right)}\right]^{2}-t_{\text {v.u.p. }}$

O coeficiente de difusão $\kappa_{0}$ é determinado por meio da expressão dada por Bentz et al. (1996), em função da relação água/cimento do concreto:

$\kappa_{0}=10^{-10+4,66 a / c} \mathrm{~cm}^{2} / \mathrm{s}$

O problema RBDO é formulado então da seguinte forma:

Encontrar: $c o b$

Que minimiza: $c o b$

Sujeito a: $\left\{\begin{array}{l}P\left[\left\{\frac{1}{\kappa_{0}}\left[\frac{c o b}{2 \operatorname{erfc}^{-1}\left(\frac{C_{\text {lim }}}{C_{0}}\right)}\right]^{2}-t_{\text {v.u.p. }}\right\} \leq 0\right] \leq P_{f_{T}}=\Phi\left[-\beta_{T}\right] \\ 0 \leq \operatorname{cob} \leq 100 \mathrm{~mm}\end{array}\right.$

Os parâmetros das variáveis aleatórias consideradas são:

Tabela 4.2 - Exemplo 1: parâmetros das variáveis aleatórias

\begin{tabular}{ccccc}
\hline Parâmetro & $\begin{array}{c}\text { Tipo de } \\
\text { distribuição }\end{array}$ & Média & C.V. & Referência \\
\hline \hline$C_{\text {lim }}$ & Uniforme & $0,90 \mathrm{~kg} / \mathrm{m}^{3}$ & 0,15 & $\begin{array}{c}\text { Mehta e Monteiro } \\
(2008)\end{array}$ \\
\hline \multirow{2}{*}{$\kappa_{0}$} & Lognormal & $\begin{array}{c}23,0572 \mathrm{~mm}^{2} / \mathrm{ano}(\mathrm{a} / \mathrm{c}=0,4) \\
67,7228 \mathrm{~mm}^{2} / \mathrm{ano}(\mathrm{a} / \mathrm{c}=0,5)\end{array}$ & 0,30 & Bentz et al. (1996) \\
\hline$C_{0}$ & Lognormal & $1,15 \mathrm{~kg} / \mathrm{m}^{3}$ & 0,30 & $\begin{array}{c}\text { McGee (1999) } / \mathrm{Val} \\
\text { e Stewart (2003) }\end{array}$ \\
\hline
\end{tabular}

Foram realizadas diversas análises adotando-se tempos de vida útil de projeto $t_{\text {v.u.p. }}$ determinísticos iguais a 30, 40 e 50 anos, coeficientes de difusão aleatórios para três relações água/cimento (conforme consta na Tabela 4.2) e índices de confiabilidade alvo $B_{T}$ variando entre 
0 e 3. No algoritmo SLA foi adotado o ponto inicial de busca para o cobrimento cob igual a $30 \mathrm{~mm}$ e o coeficiente de variação do mesmo foi adotado igual a 0,30. Foi adotada uma tolerância da função objetivo para convergência do algoritmo SLA igual a $10^{-3}$.

Os cobrimentos otimizados em função do índice de confiabilidade alvo para diferentes relações água/cimento e tempos de vida útil de projeto estão apresentados na Figura 4.10.

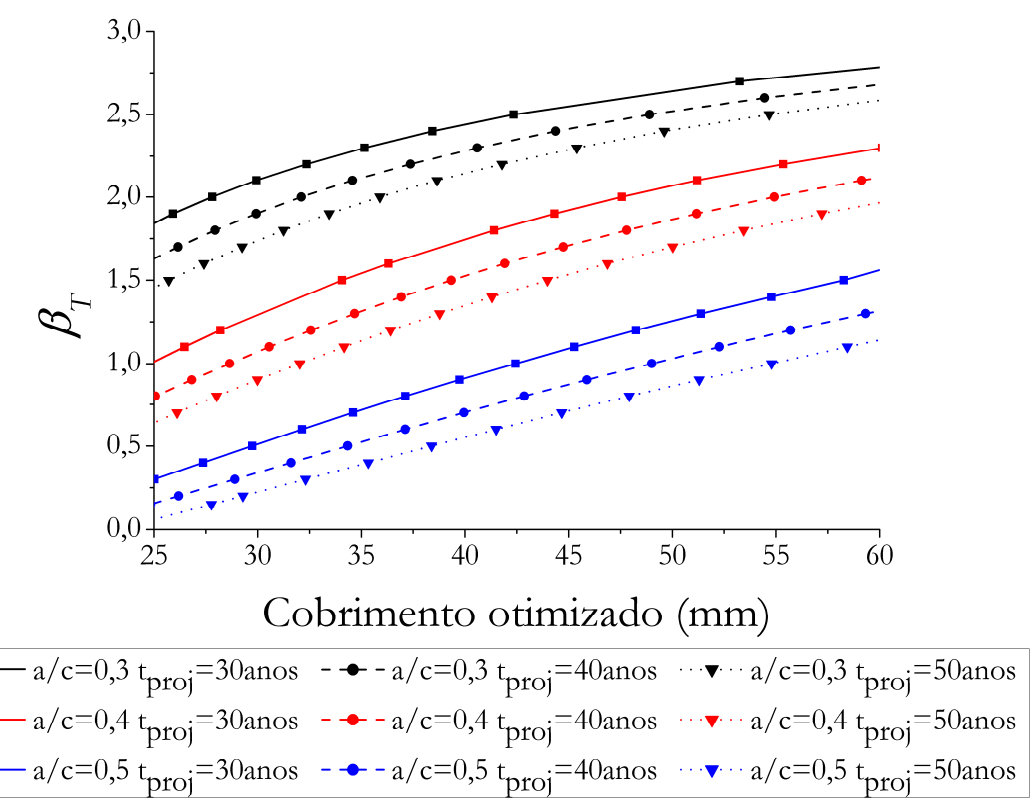

Figura 4.10 - Exemplo 1: cobrimentos otimizados em função do índice de confiabilidade alvo para diferentes relações água/cimento e tempos de vida útil de projeto

Um gráfico equivalente àquele apresentado na Figura 4.10, porém traçado em termos de probabilidade de despassivação, é apresentado na Figura 4.11. 


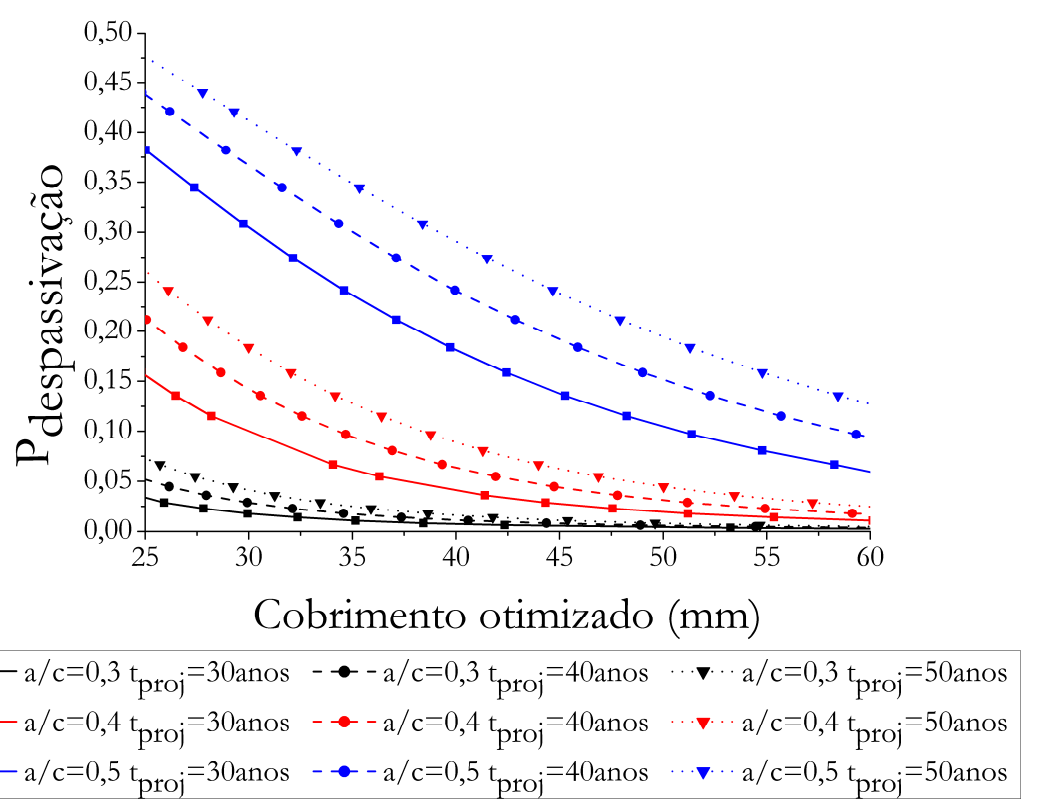

Figura 4.11 - Exemplo 1: cobrimentos otimizados em função da probabilidade de despassivação alvo para diferentes relações água/cimento e tempos de vida útil de projeto

$\mathrm{Na}$ Figura 4.10 (e equivalentemente na Figura 4.11), os pontos plotados referem-se aos pontos onde calculou-se o cobrimento ótimo para um dado índice de confiabilidade alvo especificado, partindo-se de 0 até um valor igual a $3, \operatorname{com} \Delta \beta=0,1$ de um ponto para o outro. Em alguns poucos trechos das curvas que interpolam os pontos não foi possível obter convergência, mesmo variando-se o ponto inicial de busca e diminuindo-se a tolerância. Tais instabilidades podem estar atreladas ao número limitado de iterações do minimizador utilizado. Contudo, a quantidade de pontos obtidos pelo algoritmo SLA é suficiente para demonstrar uma certa tendência de comportamento.

Observa-se na Figura 4.11 que, para que se atinja um mesmo nível de confiança com uma mesma relação água/cimento, quão maior for o tempo de vida útil de projeto, maiores serão os valores de cobrimento otimizados, conforme já esperado. Na mesma figura observa-se também que, para que se atinja uma mesma probabilidade de despassivação requerida em um mesmo tempo de vida útil de projeto, quão maior for a relação água/cimento, maior será o valor do cobrimento otimizado. Isso se explica pelo fato de que maiores relações água/cimento acarretam uma maior porosidade no concreto, o que eleva o valor do coeficiente de difusão e facilita a entrada de íons cloreto.

Além disso, na Figura 4.11, observa-se que o comportamento dos trios de curvas com uma mesma relação água/cimento tende a se tornar horizontalmente assintótico, convergindo para uma dada probabilidade de falha alvo. Nota-se que um aumento da espessura de cobrimento aumenta de fato o nível de segurança, porém esse aumento de espessura se torna cada vez menos 
efetivo quão menor for a probabilidade de falha alvo desejada. Por exemplo, tomando-se como referência a curva com uma relação água/cimento de 0,4 para um tempo de vida útil de projeto de 50 anos, os cobrimentos otimizados resultam iguais a 25, 35, 45 e $55 \mathrm{~mm}$ para probabilidades de falha iguais a $0,26,0,13,0,06$ e 0,03 , respectivamente. Tomando como referência o cobrimento otimizado de $25 \mathrm{~mm}$ e a respectiva probabilidade de falha de 0,26 , cobrimentos $40 \%$, $80 \%$ e $120 \%$ maiores resultaram em diminuições de $50 \%, 77 \%$ e $88 \%$ da probabilidade de falha. Portanto, outras medidas, como a diminuição do coeficiente de difusão do concreto por meio de melhorias em sua composição, podem ser alternativas mais efetivas em certos cenários.

Os índices de confiabilidade alvo recomendados pelo JCSS (2001) para estados limites de serviço irreversíveis variam entre 1,3 e 2,3, segundo os custos relativos das medidas de segurança adotados. Algumas curvas apresentadas na Figura 4.10 possuem trechos abaixo do índice mínimo recomendado de 1,3, especialmente as curvas que possuem uma relação água/cimento igual a 0,5. Nestes casos, reduzir a relação água/cimento do concreto se apresenta como uma alternativa bastante interessante para que os índices de confiabilidade alvo recomendados pelo JCSS (2001) sejam respeitados.

Análises que resultam em gráficos como aqueles apresentados na Figura 4.10 e na Figura 4.11 podem servir de auxílio na etapa de projeto de um elemento de concreto armado. A partir da adoção de um certo tempo de vida útil de projeto e de uma certa probabilidade de falha alvo ou, equivalentemente, de um índice de confiabilidade alvo, um cobrimento otimizado correspondente é obtido. Caso se deseje diminuir a probabilidade de falha, três alternativas são possíveis: aumentar a espessura de cobrimento, diminuir a relação água/cimento ou realizar ambas as ações. Dessa forma, o projetista tem a possibilidade de adotar a opção que julgar mais factível.

Os resultados apresentados neste exemplo demonstram a aplicabilidade do algoritmo SLA na otimização da espessura de cobrimento de um elemento de concreto armado. Os resultados dependem fortemente da definição do coeficiente de difusão adotado. Melhorias podem ser feitas a fim de reproduzir um cenário mais realístico incorporando efeitos como a redução desse coeficiente com o passar do tempo e a capacidade de ligação de cloretos ao cimento. Se tais efeitos forem incorporados, espera-se que os cobrimentos otimizados resultem em valores menores.

\subsubsection{Exemplo 2: WASM/RBDO aplicados ao MEC em um domínio quadrado}

No presente exemplo busca-se otimizar o valor da espessura de cobrimento de um elemento de concreto submetido a penetração de íons cloreto. O problema RBDO formulado é 
resolvido por meio do método de simulação ponderada WASM, conforme apresentado na seção 4.6 da presente tese. O modelo difusivo via MEC é utilizado para obter os valores das concentrações de cloretos ao longo do tempo. O esquema de solução do problema é apresentado na Figura (4.12).

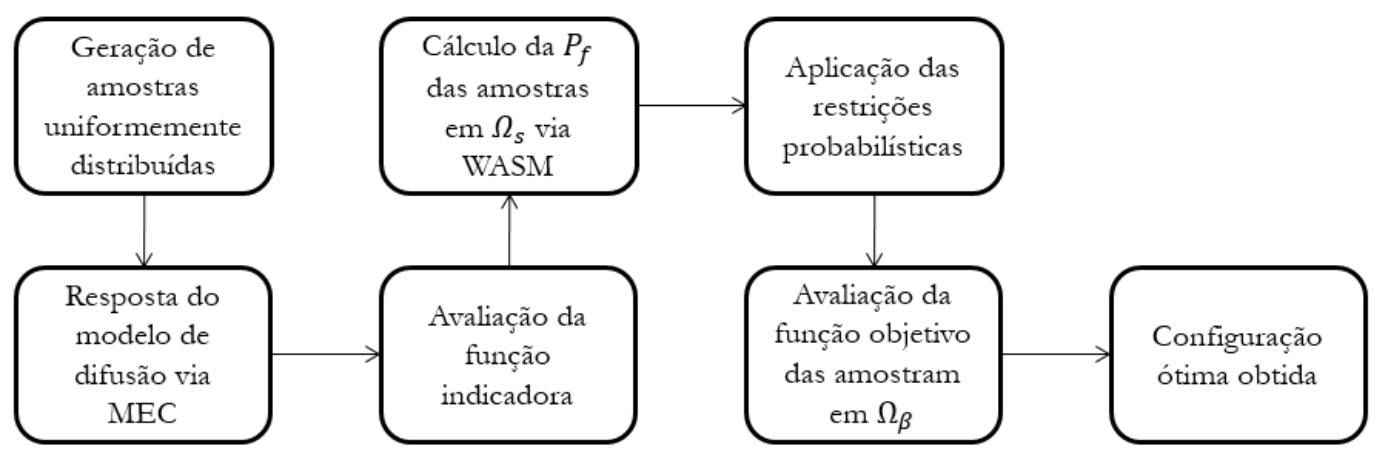

Figura 4.12 - Exemplo 2: esquema de solução do problema RBDO

A geometria da seção transversal estudada neste exemplo é ilustrada na Figura (4.13).

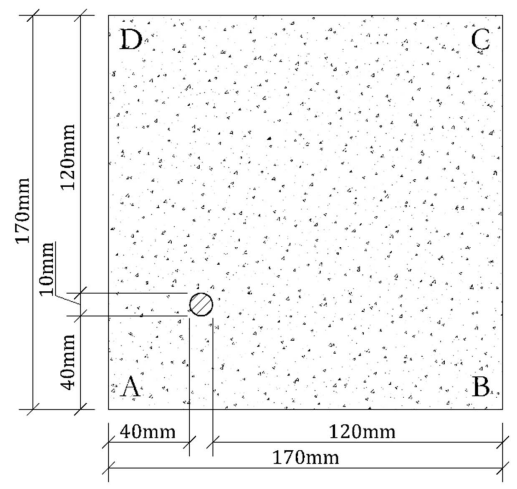

Figura 4.13 - Exemplo 2: geometria

Conforme consta na Figura 4.13, no interior do domínio de concreto há uma barra de aço de $10 \mathrm{~mm}$ de diâmetro com um cobrimento de $40 \mathrm{~mm}$. O diâmetro dessa barra é somente ilustrativo e não se considera sua influência em momento algum na análise. Variando-se as condições de contorno, são analisados dois casos distintos, conforme ilustrado na Figura 4.14. 

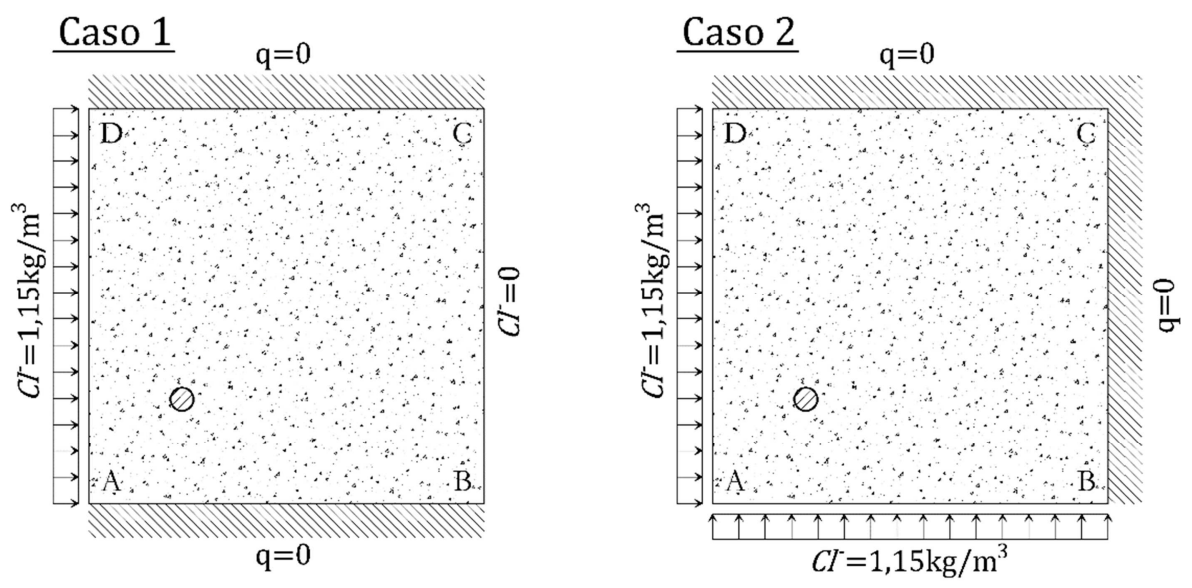

Figura 4.14 - Exemplo 2: condições de contorno

$\mathrm{Na}$ Figura 4.14, o caso 1 retrata um fluxo unidimensional de íons cloreto, que é um regime de fluxo representativo em elementos estruturais que possuem uma dimensão muito menor do que as outras duas, como as lajes, por exemplo. O caso 2 retrata um fluxo bidimensional de íons cloreto, que é um regime de fluxo representativo em elementos estruturais que possuem duas de suas dimensões muito menores do que a outra, como as vigas, por exemplo.

A equação de estado limite que define o limiar entre a ocorrência ou não da despassivação é definida da seguinte forma:

$G=t_{\text {desp }}-t_{\text {v.u.p.p. }}$

em que $t_{d e s p}$ é o tempo para que ocorra a despassivação e $t_{v . u . p .}$ é o tempo de vida útil de projeto. O tempo para ocorrência da despassivação é calculado por meio do modelo via MEC descrito na presente tese.

Os parâmetros das variáveis aleatórias consideradas são:

Tabela 4.3 - Exemplo 2: parâmetros das variáveis aleatórias

\begin{tabular}{ccccc}
\hline Parâmetro & $\begin{array}{c}\text { Tipo de } \\
\text { distribuição }\end{array}$ & Média & C.V. & Referência \\
\hline \hline$C_{\text {lim }}$ & Uniforme & $0,90 \mathrm{~kg} / \mathrm{m}^{3}$ & 0,15 & Mehta e Monteiro (2008) \\
\hline$\kappa_{0}$ & Lognormal & $\begin{array}{c}23,0572 \mathrm{~mm}^{2} / \mathrm{ano} \\
(\mathrm{a} / \mathrm{c}=0,4)\end{array}$ & 0,30 & Bentz et al. (1996) \\
\hline$C_{0}$ & Lognormal & $1,15 \mathrm{~kg} / \mathrm{m}^{3}$ & 0,30 & $\begin{array}{c}\text { McGee (1999) / Val e Stewart } \\
(2003)\end{array}$ \\
\hline cob & Normal & $40,00 \mathrm{~mm}$ & 0,30 & - \\
\hline
\end{tabular}


O cobrimento cob é a variável de projeto aleatória que se busca otimizar. Ao longo das simulações feitas, o valor numérico do cobrimento aleatório $c o b_{i}$ de uma dada amostra $i$ é utilizado para a definição automática das coordenadas do ponto interno para o cálculo da concentração de cloretos no modelo via MEC. No caso 1, os pontos internos estão localizados ao longo de uma linha paralela a aresta $\mathrm{AB}$ e distante $40 \mathrm{~mm}$ da mesma. No caso 2, os pontos internos estão localizados ao longo da diagonal AC. O esquema do posicionamento dos pontos internos ao longo das simulações está ilustrado na Figura 4.15, sendo $\operatorname{cob}_{\mu}$ o cobrimento médio, igual a $40 \mathrm{~mm}$.
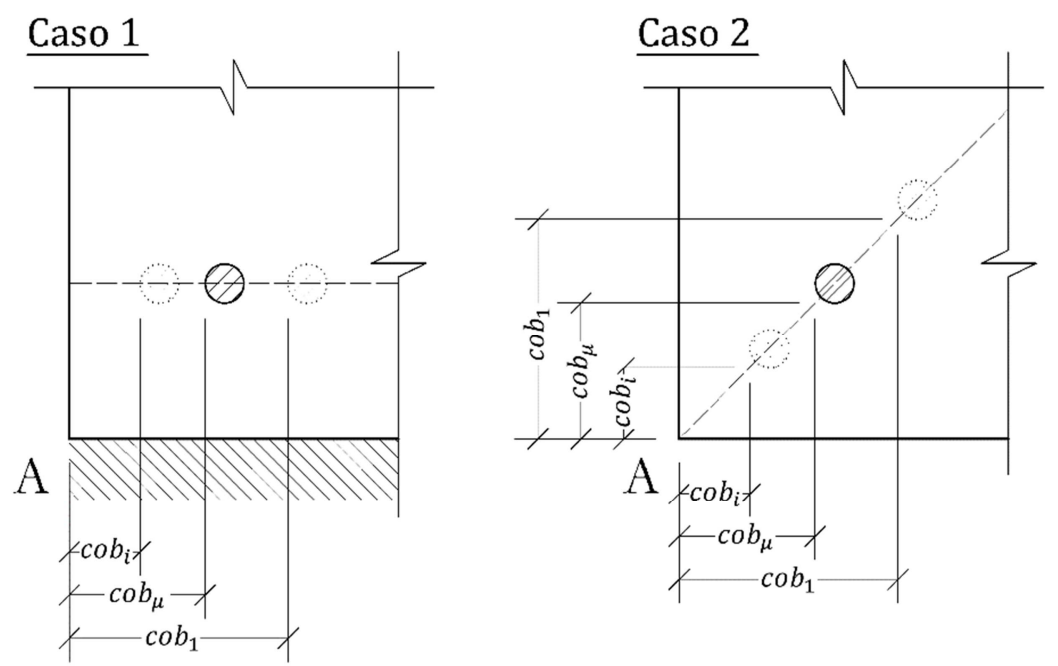

Figura 4.15 - Exemplo 2: esquema de posicionamento dos pontos internos amostrados ao longo das simulações

Para a solução numérica via MEC o contorno foi discretizado em 68 elementos descontínuos e isoparamétricos de aproximação linear com $10 \mathrm{~mm}$ de comprimento cada um, totalizando 136 nós e 272 graus de liberdade. Utilizam-se 10 pontos de Gauss por elemento para a integração numérica. A discretização temporal foi feita em 25 passos de tempo partindo-se do ano 0 até o ano 50. Assume-se que o domínio possua potencial nulo no instante $t=0$ (no início da análise). Além disso, assume-se que o valor do potencial e do fluxo em cada ponto do domínio e do contorno permaneçam constantes em cada passo de tempo. Em cada análise feita foram geradas dez mil amostras como dados de entrada no modelo via MEC.

Foram realizadas diversas análises adotando-se tempos de vida útil de projeto $t_{\text {v.u.p. }}$ determinísticos iguais a 30, 40 e 50 anos e índices de confiabilidade alvo $\beta_{T}$ variando entre -1 e 3 . Os cobrimentos otimizados em função do índice de confiabilidade alvo para diferentes tempos de vida útil de projeto para os casos 1 e 2 estão apresentados na Figura 4.16. 


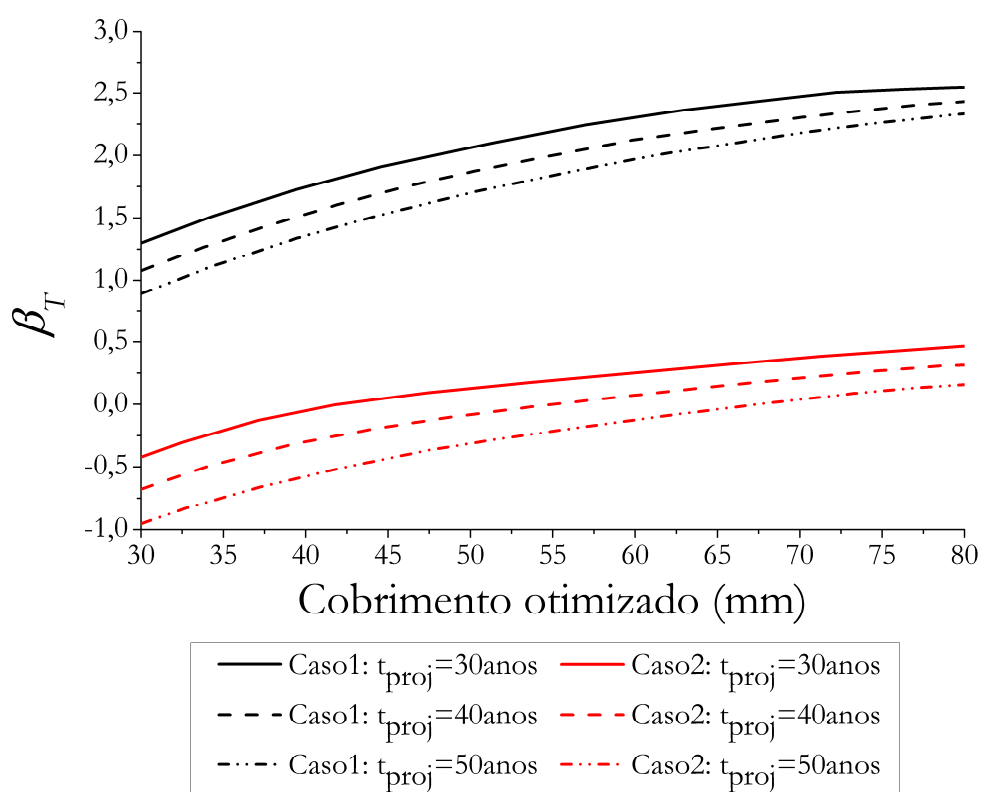

Figura 4.16 - Exemplo 2: cobrimentos otimizados em função do índice de confiabilidade alvo para diferentes tempos de vida útil de projeto para os casos 1 e 2

Um gráfico equivalente àquele apresentado na Figura 4.16, porém traçado em termos de probabilidade de despassivação, é apresentado na Figura 4.17.

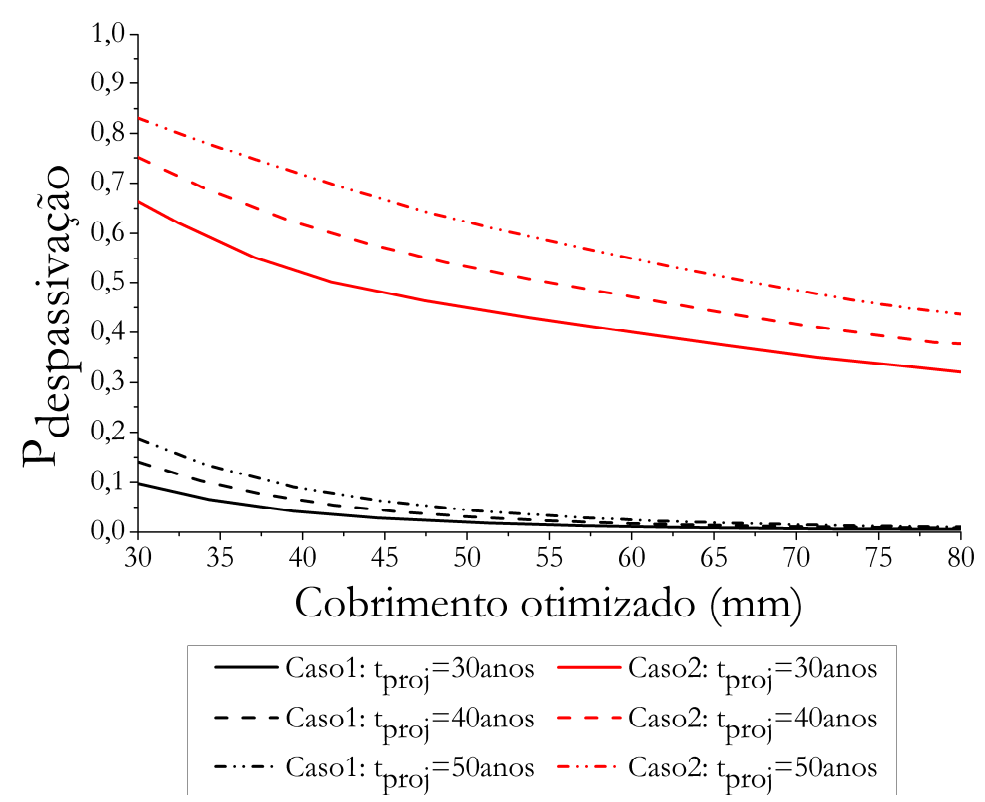

Figura 4.17 - Exemplo 2: cobrimentos otimizados em função da probabilidade de despassivação alvo para diferentes tempos de vida útil de projeto para os casos 1 e 2

Observando-se a Figura 4.16 e a Figura 4.17 é possível notar que o intervalo de valores de índices de confiabilidade alvo para os dois casos é bastante distinto. Para a faixa de cobrimentos otimizados resultantes entre $30 \mathrm{~mm}$ e $80 \mathrm{~mm}$, o índice de confiabilidade alvo do caso 1 varia entre 0,8 e 2,6 e do caso 2 varia entre -1 e 0,5 . Esse resultado corrobora com resultados de análises 
determinísticas e probabilísticas de exemplos apresentados na presente tese, onde as concentrações de cloretos e probabilidades de despassivação são consideravelmente maiores para regimes de difusão bidimensionais em comparação com regimes de difusão unidimensionais.

O resultado obtido neste exemplo reforça o resultado obtido no exemplo 1, resolvido pelo algoritmo SLA. Observa-se na Figura 4.17 que o comportamento dos trios de curvas de um mesmo caso tende a se tornar horizontalmente assintótico, convergindo para uma dada probabilidade de falha alvo. Nota-se que um aumento da espessura de cobrimento aumenta de fato o nível de segurança, porém este aumento de espessura se torna cada vez menos efetivo quão menor for a probabilidade de falha alvo desejada. Em outras palavras, a inclinação da curva de probabilidade de falha alvo (ou equivalentemente da curva de índice de confiabilidade alvo) vai tendendo a se tornar nula quão maior for o cobrimento otimizado resultante.

Além disso, para um mesmo valor de cobrimento otimizado, observa-se que a taxa de crescimento do índice de confiabilidade alvo em função do cobrimento otimizado (inclinação da curva da Figura 4.16) é maior no caso 1 do que no caso 2. Contudo, analisando-se a taxa de decrescimento da probabilidade de falha alvo em função do cobrimento otimizado (inclinação da curva da Figura 4.17), nota-se uma situação oposta, ou seja, a inclinação é maior no caso 2 do que no caso 1. Matematicamente isso se explica devido a relação não linear entre $\beta_{T}$ e $P_{f_{T}}$, onde $P_{f_{T}}=\Phi\left(-\beta_{T}\right)$. Valores de $\beta_{T}$ mais próximos de 0 , como no caso 2 , possuem probabilidades associadas maiores e, consequentemente, geram um maior gradiente do que no caso de $\beta_{T}$ distante de 0 , como no caso 1 . Em termos de projeto, isso significa que um hipotético aumento de espessura de cobrimento no caso 2 (fluxo bidimensional) gera um ganho maior de segurança do que um mesmo aumento no caso 1 (fluxo unidimensional). Tal fato reforça a importância do controle e da escolha de uma espessura de cobrimento adequada para a proteção das armaduras em elementos de concreto armado.

Os índices de confiabilidade alvo recomendados pelo JCSS (2001) para estados limites de serviço irreversíveis variam entre 1,3 e 2,3, segundo os custos relativos das medidas de segurança adotados. Observa-se na Figura 4.16 que as três curvas referentes ao caso 1 (fluxo unidimensional) respeitam quase que em sua totalidade o índice de confiabilidade mínimo de 1,3. Contudo, para o caso 2 (fluxo bidimensional), nos caizados estão bastante abaixo deste índice de confiabilidade mínimo recomendado. Uma vez que aumentar o cobrimento não aparenta ser uma medida eficaz para um acréscimo de segurança, no caso 2 é preferível reduzir a relação água/cimento do concreto para que os índices de confiabilidade alvo recomendados pelo JCSS (2001) sejam respeitados. 
Este exemplo demonstrou o acoplamento entre o modelo difusivo via MEC e a solução de um problema RBDO por meio do WASM na otimização da espessura de cobrimento de um elemento de concreto armado para fluxos uni e bidimensionais de íons cloreto. Os cobrimentos otimizados nos casos 1 e 2 resultaram bastante distintos devido às condições de contorno. Dessa forma, a influência que as condições de contorno possuem no processo de otimização do cobrimento foi evidenciada. Além disso, melhorias podem ser feitas a fim de reproduzir um cenário mais realístico incorporando efeitos como a redução do coeficiente de difusão com o passar do tempo e a capacidade de ligação de cloretos ao cimento. Se tais efeitos forem incorporados, espera-se que os cobrimentos otimizados resultem em valores menores. 


\section{CONSIDERAÇÕES FINAIS}

Neste capítulo são apresentadas, resumidamente, as considerações finais da tese. As principais discussões em relação às análises determinísticas, probabilísticas e de otimização realizadas, apesar de já terem sido conduzidas ao longo do texto, são aqui sintetizadas. Por fim, são feitas sugestões para a continuidade da pesquisa.

\subsection{Sobre as análises determinísticas}

O ingresso de íons cloreto e a sucessiva corrosão das armaduras é o principal mecanismo de deterioração da capacidade resistente de elementos estruturais de concreto armado. O principal mecanismo de transporte dos íons cloreto no interior do concreto é a difusão. Quando, ao longo do processo difusivo, a concentração de cloretos na interface concreto/armadura atinge um valor limite, ocorre a despassivação das armaduras. Após a despassivação das armaduras, os mecanismos deletérios ocasionados pelas reações químicas da corrosão começam a comprometer o desempenho da estrutura.

A segurança frente ao colapso associada a um dado elemento estrutural decai rapidamente após o início do processo corrosivo. Dessa forma, é fundamental prever adequadamente quando se dará o seu início. Existem diversas soluções analíticas disponíveis na literatura para tratar do fenômeno da difusão. Contudo, tais soluções apresentam elevadas simplificações ou podem ser aplicadas a poucos casos específicos. Com o objetivo de contornar tais limitações e buscar uma ferramenta mais abrangente, no presente trabalho é proposto o desenvolvimento de uma ferramenta numérica que seja capaz de modelar o fenômeno adequadamente.

O método dos elementos de contorno (MEC) tem sido amplamente empregado na modelagem e solução de problemas de engenharia. Dentre as principais vantagens deste método numérico destaca-se a possibilidade de redução da dimensão do problema, fácil conformação às fronteiras do domínio, facilidade para tratar de singularidades e ausência de aproximações das equações governantes do problema. Outra grande vantagem do método, especificamente quando aplicado a problemas de difusão, é a redução do tempo de processamento se comparado com outros métodos numéricos. Isso se deve especialmente pelo fato de que a formulação trabalha com parâmetros do contorno a priori e, após a solução ser alcançada, informações do domínio podem ser obtidas a partir do conhecimento dos parâmetros do contorno. 
Após o desenvolvimento e implementação computacional, o MEC demonstrou ser uma abordagem eficaz no tratamento de problemas de difusão em elementos de concreto. O código computacional desenvolvido foi validado por meio de exemplos de difusão em regime estacionário e transiente. Destaque é dado ao baixo tempo de processamento requerido para a execução do programa desenvolvido, tornando viável o seu acoplamento com algoritmos de confiabilidade e otimização.

Conforme ficou claro nos exemplos de validação do código, o processo de solução numérica adotando a estratégia de marcha no tempo requer certa quantidade de passos de tempo para convergir com a resposta obtida a partir de soluções analíticas. Dessa forma, em qualquer análise, é importante que a idade para a qual se deseje calcular o perfil de concentração de cloretos via MEC, tenha um número adequado de passos de tempo anteriores ao tempo desejado para determinação do perfil, com o objetivo de garantir uma melhor precisão do método.

A possibilidade de considerar condições de contorno variáveis no tempo é outra potencialidade do método. Tais condições são facilmente impostas, ao contrário do que ocorre em soluções analíticas, onde esse procedimento pode ser bastante dificultoso. A resposta obtida com condições de contorno variáveis no tempo pode ser bastante distinta da resposta obtida com condições de contorno fixas no tempo, conforme apresentado em alguns exemplos. Além disso, o método apresentado permite modelar contornos de formato curvo.

\subsection{Sobre as análises probabilísticas}

A difusão de íons cloreto no concreto é um fenômeno altamente aleatório. Dessa forma, procurar descrever tal fenômeno desconsiderando as inerentes incertezas dos parâmetros envolvidos é uma maneira incompleta de abordar o problema. A aplicação da teoria de confiabilidade, além de fornecer ferramentas para suprir essa carência, é capaz de quantificar o nível de segurança associado a um determinado estado estrutural indesejado (modo de falha). No caso da difusão de íons cloreto no concreto, o estado indesejado, chamado também de estado limite de iniciação da corrosão, pode ser definido de duas maneiras equivalentes. Na primeira, define-se como estado indesejado aquele em que a concentração de cloretos na interface concreto/armadura atinge um valor limite que desencadeia o início da corrosão. Na outra, definese como estado indesejado aquele em que o tempo de vida útil de projeto é igual ao tempo previsto para ocorrência da despassivação.

Nos últimos anos a teoria de confiabilidade vem sendo cada vez mais aplicada a diversos problemas de engenharia estrutural. No caso específico da difusão de íons cloreto e corrosão das armaduras, diversas análises probabilísticas foram conduzidas nos últimos 30 anos englobando 
aspectos como: domínios difusivos com uma, duas ou três dimensões, variabilidade espacial da ação da corrosão ao longo das barras de aço e seus efeitos no comportamento mecânico estrutural, consideração de diferentes estados limites, efeitos provocados pelas variações climáticas, entre outros. Contudo, apesar do tratamento probabilístico, grande parte dos trabalhos adota modelos de difusão simplificados, como a lei de Fick. Dessa forma, por mais refinada que uma análise de confiabilidade possa ser conduzida, adotar um modelo de difusão de cloretos impreciso pode resultar em respostas pouco representativas do real comportamento do fenômeno.

O modelo em elementos de contorno desenvolvido neste trabalho, acoplado com algoritmos de confiabilidade, se insere nesse contexto. Conforme já comentado, o modelo via MEC apresenta um elevado potencial de representatividade do fenômeno. Dessa forma, o mesmo foi acoplado com o método de simulação de Monte Carlo (MSMC) para obtenção das probabilidades de falha. O MSMC é um dos métodos de simulação mais conhecidos e utilizados na atualidade. Além de possuir uma formulação simples, esse método é capaz de lidar adequadamente com equações de estado limite não lineares e considerar variáveis aleatórias com distribuições estatísticas quaisquer. A probabilidade de falha estimada por meio do MSMC tende a ser próxima da probabilidade de falha exata se um número adequado de simulações for realizado.

Foi apresentado um exemplo de aplicação comparando a lei de Fick com o modelo via MEC em termos de resposta probabilística. As probabilidades de despassivação resultaram cada vez mais distintas entre si, conforme as condições de contorno adotadas no modelo numérico se distanciavam das hipóteses assumidas pela lei de Fick. Além disso, condições de contorno diferentes, para um mesmo domínio, resultam em probabilidades de despassivação consideravelmente distintas associadas a tempos de despassivação calculados de maneira determinística.

Curvas de isoprobabilidade se mostraram uma ferramenta de análise bastante útil para visualizar o nível de segurança associado a pontos contidos na seção transversal de um elemento de concreto armado submetido à difusão de íons cloreto. Tais curvas permitem uma reflexão a respeito do posicionamento das armaduras e do valor da espessura de cobrimento. Os históricos de evolução das probabilidades de despassivação em distintas áreas de uma mesma seção transversal podem ser muito diferentes. Tal comportamento pode ser compreendido a partir das condições de contorno nas proximidades do ponto de domínio e a partir da geometria do domínio onde o processo de difusão ocorre. Dessa forma, pode acontecer que algumas armaduras sejam mais suscetíveis a despassivação do que outras. Logo, a importância do 
posicionamento e controle do cobrimento das barras de aço em elementos de concreto armado é evidenciada.

Os conceitos de estado limite de durabilidade e estado limite de iniciação da corrosão são pouco discutidos na engenharia cotidiana e estão discretamente inseridos em normas técnicas. Além disso, as poucas normas existentes que englobam estados limites de iniciação da corrosão por íons cloreto não especificam o nível de agressividade ambiental no qual a estrutura está inserida e nem mesmo as condições de contorno do processo de difusão de íons. Conforme foi destacado nos exemplos apresentados, o nível de agressividade ambiental e as condições de contorno exercem papel fundamental no histórico de probabilidade de despassivação. Dessa forma, a recomendação de um único índice de confiabilidade para diversos casos possíveis é excessivamente generalista, podendo gerar resultados a favor ou contra a segurança. A definição de tais índices recomendados é ainda uma questão em aberto, sendo que a ferramenta computacional aqui desenvolvida pode auxiliar nessa tarefa.

\subsection{Sobre as análises de otimização}

Em engenharia, o processo de projetar e gerir sistemas é, sob vários aspectos, uma tarefa bastante complexa. Busca-se utilizar da melhor forma possível os recursos finitos disponíveis a fim de que o produto resultante atenda as necessidades da sociedade. Os processos de otimização são excelentes ferramentas que auxiliam nesse processo de busca.

$\mathrm{Na}$ presente tese foram explorados os conceitos e aspectos fundamentais envolvidos nos processos de otimização, bem como foram apresentadas distintas formas de se formularem problemas de otimização dentro da área de engenharia de estruturas. A consideração de incertezas em um processo de otimização é uma forma consistente de tratar o problema de difusão de íons cloreto em elementos de concreto armado. As restrições do problema são escritas em termos de probabilidades de falha alvo ou índices de confiabilidade alvo. As incertezas afetam fortemente o processo de busca e o resultado da configuração otimizada, sendo que podem ser introduzidas na função objetivo, nas restrições de igualdade, de desigualdade e laterais.

Em apenas um reduzido número de casos particulares, soluções analíticas fechadas para problemas de otimização sob incertezas são possíveis de serem obtidas. Processos iterativos se fazem necessários na maior parte das vezes, onde a função objetivo e a probabilidade de falha necessitam ser calculadas repetidas vezes até a convergência ser alcançada.

Nesse contexto, a otimização estrutural baseada em confiabilidade RBDO, adotada neste trabalho, se apresenta como uma abordagem consistente e capaz de tratar adequadamente as incertezas presentes no problema. Em sua formulação clássica, a abordagem RBDO emprega um 
procedimento de laço duplo, envolvendo um laço interno para cálculo de parâmetros de confiabilidade, e outro laço externo, contendo procedimentos de otimização para busca da configuração otimizada. Uma maneira alternativa de formular o problema consiste em acoplar os dois laços em um único, reduzindo substancialmente o tempo computacional necessário para a solução do problema. Dois algoritmos dessa natureza são apresentados e utilizados para a otimização da espessura de cobrimento em elementos de concreto armado submetidos à penetração de íons cloreto: a abordagem de laço único SLA e o método de simulação ponderada WASM acoplado a uma metodologia RBDO.

Os exemplos de aplicação, por meio das duas abordagens de otimização, apresentaram resultados qualitativamente similares. Foram obtidas curvas de índices de confiabilidade alvo versus cobrimentos otimizados. Tais curvas podem servir de auxílio na etapa de projeto de elementos de concreto armado a fim de propiciar a manutenção de um dado nível de segurança desejado durante toda a vida útil estrutural de projeto. Além disso, é possível verificar a alteração no nível de segurança gerado por mudanças de parâmetros de projeto como a espessura de cobrimento e a relação água/cimento.

A influência das condições de contorno foram também evidenciadas no processo de otimização. Um aumento da espessura de cobrimento aumenta de fato o nível de segurança contra a despassivação das armaduras, porém esse aumento de espessura se torna cada vez menos efetivo quão menor for a probabilidade de falha alvo desejada. Fluxos de cloretos uni e bidimensionais resultam em valores de cobrimentos otimizados bastante distintos. Consequentemente, tal distinção está atrelada ao formato do contorno do elemento estrutural. Um aumento de espessura de cobrimento em um problema de difusão bidimensional suscita um ganho maior de segurança do que um mesmo aumento de espessura em um problema de difusão unidimensional.

\subsection{Sugestões para trabalhos futuros}

Ainda que a pesquisa descrita na presente tese tenha buscado propor algumas metodologias alternativas e inovadoras, ainda existe (e sempre existirá) muito a se investigar na área de durabilidade estrutural. A curiosidade envolvida com aspectos dessa área do conhecimento vem adquirindo especial importância e destaque nos últimos anos, sendo por vezes infelizmente motivada por acidentes e tragédias com perda de vidas humanas. Assim, alguns pontos abordados nesta tese podem ser aprofundados. A seguir, são sugeridos alguns desses pontos de extensão, ramificação e conexão com outros temas: 
- Implementação de um algoritmo com passos de tempo de tamanho adaptativo a fim de acelerar o processo de convergência do MEC;

- Refinar o cálculo/determinação do coeficiente de difusão de cloretos no concreto considerando-se fatores como a taxa de ligação de cloretos à matriz de cimento, a composição do concreto, a evolução da microestrutura do concreto ao longo do tempo, nível de dano/fissuração no domínio de concreto e condições ambientais;

- Realizar análises variando-se a concentração superficial de cloretos com o tempo a partir de expressões propostas na literatura e a partir de informações de campo e/ou laboratoriais;

- Realizar análises multifásicas do concreto, particularizando o comportamento difusivo nas várias fases que compõe esse material;

- Acoplar o modelo de difusão proposto com modelos que considerem esforços mecânicos estáticos/dinâmicos, mecanismos de evolução de danificação e fissuração. O próprio método dos elementos de contorno é um excelente método para realizar tal tarefa;

- Analisar o período de propagação da corrosão por meio de um acoplamento do modelo de difusão proposto com modelos de fissuração interna originada pelos produtos expansivos das reações de corrosão;

- Estender a formulação do MEC para modelagem da difusão em domínios tridimensionais;

- Realizar análises de otimização envolvendo outros parâmetros como a relação água/cimento e o coeficiente de difusão de cloretos. Tais investigações possuem forte potencial de aprofundamento e interação com aspectos ligados à ciência dos materiais;

- Realizar análises de otimização multiobjetivo, envolvendo simultaneamente, por exemplo, estados limites de aberturas de fissuras e concentração de cloretos. 


\section{REFERÊNCIAS BIBLIOGRÁFICAS}

ABABNEH, A.; BENBOUDJEMA, F.; XI, Y. Chloride Penetration in Nonsaturated Concrete. Journal of Materials in Civil Engineering, v.15, n.2, p. 183-191, 2003.

ABDUL RAZAK, H.; CHAI, H.K.; WONG, H.S. Near surface characteristics of concrete containing supplementary cementing materials. Cement and Concrete Composites, v.26, p.883-889, 2004.

ABEL, N.H. Ouvres complètes Norvegien Christiania, v.1, 1823.

ABOUHUSSIEN, A.A.; HASSAN, A.A.A. Experimental and Empirical Time to Corrosion of Reinforced Concrete Structures under Different Curing Conditions Advances in Civil Engineering, v.2014, 9 p., 2014.

ABRAMOWITZ, M.; STEGUN, I.A. Handbook of Mathematical Functions. Dover, New York, 1965.

ABREU, A.I. A Boundary Integral Formulation Based On The Convolution Quadrature Method For Transient Heat Conduction In Functionally Graded Materials. In: Symposium of the International Association for Boundary Element - IABEM 2013, Chile, 2013.

AHMED, M.S.; KAYALI, O.; ANDERSON, W. Evaluation of binary and ternary blends of pozzolanic materials using the rapid chloride permeability test. Journal of Materials in Civil Engineering, v.21, p.446-453, 2009.

AKIYAMA, M.; FRANGOPOL, D.M.; MATSUZAKI, H. Life-cycle reliability of RC bridge piers under seismic and airborne chloride hazards. Earthquake Engineering and Structural Dynamics, v.40, p.1671-1687, 2011.

AKIYAMA, M.; FRANGOPOL, D.M.; SUZUKI, M. Integration of the effects of airborne chlorides into reliabilitybased durability design of reinforced concrete structures in a marine environment. Structure and Infrastructure Engineering, v.8, n.2, p.125-134, 2012.

AL-GAHTANI, A.S.; RASHEEDUZZAFAR; AL-SAADOUN S.S. Rebar corrosion and sulfate resistance of blastfurnace slag cement. Journal of Materials in Civil Engineering, v.6, p.223-233, 1994.

AL-HARTHY, A.S.; STEWART, M.G.; MULLARD, J. Concrete cover cracking caused by steel reinforcement corrosion. Magazine of Concrete Research, v.63, p.655-667, 2011.

AL-JAWARY, M.A.; RAVNIK, J. WROBEL, L.C.; SKERGET, L. Boundary element formulations for the numerical solution of two-dimensional diffusion problems with variable coefficients. Computers and Mathematics with Applications, v.64, p.2695-2711, 2012.

AL-KUTTI, W.A.; RAHMAN, M.K.; SHAZALI, M.A.; BALUCH, M.H. Enhancement in Chloride Diffusivity due to Flexural Damage in Reinforced Concrete Beams. Journal Of Materials In Civil Engineering, v.26, p.658-667, 2014. AL-KUTTI, W.A.S. Simulation of chloride transport in concrete with stress induced damage. Ph.D. thesis, King Fahd University of Petroleum and Minerals, Dhahran, Saudi Arabia, 2011.

ALMUSALLAM, A.A. Effect of degree of corrosion on the properties of reinforcing steel bars. Construction and Building Materials, v.15, issue 8, p.361-368, 2001.

ALONSO, C.; CASTELlOTE, M.; ANDRADE, C. Chloride threshold dependence of pitting potential of reinforcements. Electrochimica Acta, v.47, p.3469-3481, 2002.

AMPADU, K.O.; TORII, K.; KAWAMURA, M. Beneficial effect of fly ash on chloride diffusivity of hardened cement paste. Cement and Concrete Research, v.4, p. 585-590, 1999.

ANDRADE, C. Calculation of chloride diffusion-coefficients in concrete from ionic migration measurements. Cement and Concrete Research, v.23, p.724-742, 1993.

ANDRADE, C. Future trends in research on reinforcement corrosion. In: Poursaee, A. Corrosion of Steel in Concrete Structures. Woodhead publishing, 1 ed., cap.14, p 269-284, 2016. 
ANDRADE, C. Reliability analysis of corrosion onset: initiation limit state. Journal of Structural Integrity and Maintenance, v.2, n.4, p.200-208, 2017.

ANDRADE, C.; CASTEllote, M.; ALONSO, C.; GONZÁLEZ, C. Non-steady-state chloride diffusion coefficients obtained from migration and natural diffusion tests. Part I: Comparison between several methods of calculation. Materials and Structures, v.33, p.21-28, 2000.

ANG, A.H.-S.; TANG, W.H. Probability concepts in engineering, Emphasis on Applications to Civil and Environmental Engineering, 2nd edition, John Wiley \& Sons, 2007.

ANGST, U.M.; POLDER, R. Spatial variability of chloride in concrete within homogeneously exposed areas. Cement and Concrete Research, v.56, p. 40-51, 2014.

ANN, K.Y.; AHN, J.H.; RYOU, J.S. The importance of chloride content at the concrete surface in assessing the time to corrosion of steel in concrete structures. Construction and Building Materials, n.23, p. 239-245, 2009.

AOUES Y.; CHATEAUNEUF, A. Benchmark study of numerical methods for reliability-based design optimization. Structural and Multidisciplinary Optimization, v.41, p.277-294, 2010.

APOSTOLOPOULOS, C.A.; KAPPATOS, V. Tensile properties of corroded embedded steel bars B500c in concrete. International Journal of Structural Integrity, v.4, p. 275-294, 2013.

APOSTOLOPOULOS, C.A.; PAPADAKIS, V.G. Consequences of steel corrosion on the ductility properties of reinforcement bar. Construction and Building Materials, v.22, n.12, p.2316-2324, 2008.

APOSTOLOPOUlOS, C.A.; PAPADOPOUlOS, M.P. Tensile and low cycle fatigue behavior of corroded reinforcing steel bars S400. Construction and Building Materials, v.21, p.855-864, 2007.

APOSTOLOPOUlOS, C.A.; PAPADOPOUlOS, M.P.; PANTELAKIS, S.G. Tensile behavior of corroded reinforcing steel bars BSt 500s. Construction and Building Materials, v.20, p.782-789, 2006.

ARAL, M.M.; TANG, Y. A boundary only procedure for time-dependent diffusion equations. Applied Mathematical Modelling, v.12, p.610-618, 1988.

ARORA, J.S. Introduction to Optimum Design, 4 ed., Elsevier, 2017.

ARYA, C.; BUENFELD, N.R.; NEWMAN, J.B. Factors influencing chloride-binding in concrete. Cement and concrete research, v.20, p.291-300, 1990.

ARYA, C.; XU, Y. Effect of cement type on chloride binding and corrosion of steel in concrete. Cement and Concrete Research, v.25, p.893-902, 1995.

ASBRIDGE, A.H.; CHADBOURN, G.A.; PAGE, C.L. Effects of metakaolin and the interfacial transition zone on the diffusion of chloride ions through cement mortars. Cement and Concrete Research, v.31, p.1567-1572, 2001.

ASSOCIAÇÃO BRASILEIRA DE NORMAS TÉCNICAS (ABNT). Projeto de estruturas de concreto procedimento (NBR 6118), Rio de Janeiro, 238 p., 2014.

AUDENAERT, K.; YUAN, Q.; DE SCHUTTER; G. On the time dependency of the chloride migration coefficient in concrete. Construction and Building Materials, v.24, p.396-402, 2010.

AUSTIN, S.A.; LYONS, R.; ING, M.J. Electrochemical Behavior of Steel-Reinforced Concrete During Accelerated Corrosion Testing. Corrosion, v.60, p.203-212, 2004.

AUYEUNG, Y.; BALAGURU, P.; CHUNG, L. Bond Behavior of Corroded Reinforcement Bars. ACI Materials Journal, v.97, p.214-220, 2000.

AZEVEDO, J.P.S.; WROBEL, L.C. Non-linear heat conduction in composite bodies: a boundary element formulation. International Journal for Numerical Methods in Engineering, v.26, p.19-38, 1988. 
AZIS, M.I.; CLEMENTS, D.L. Nonlinear transient heat conduction problems for a class of inhomogeneous anisotropic materials by BEM. Engineering Analysis with Boundary Elements, v.32, n.12, p.1054-1060, 2008.

BADOGIANNIS, E.; TSIVILIS, S. Exploitation of poor Greek Kaolins: durability of metakaolin concrete. Cement and Concrete Composites, v.31, p.128-133, 2009.

BAMFORTH, P.; CHAPMAN-ANDREWS, J. Long term performance of RC elements under U.K. coastal exposure conditions. In: Swamy, N. (Ed.), International Conference on Corrosion and Corrosion Protection of Steel in Concrete. Sheffield Academic Press, p.139-156, 1994.

BAMFORTH, P.B. Enhancing reinforced concrete durability: Guidance on selecting measures for minimizing the risk of reinforcement in concrete. Concrete Society, Technical Report No. 61, 2004.

BAROGHEL-BOUNY, V.; WANG, X.; THIÉRY, M. Prediction of chloride binding isotherms by analytical model or numerical inverse analysis. In: Proceedings of the 2nd Symposium on Service Life Design for Infrastructures. (DBMC Service life). Delft University of Technology, 2010.

BASHEER, L.; KROPP, J.; CLELAND, D. Assessment of the durability of concrete from its permeation properties: a review. Construction and Building Materials, v.15, p.93-103, 2002.

BASTIDAS-ARTEAGA, E.; CHATEAUNEUF, A.; SÁNCHESSILVA, M.; BRESSOLETTE, P.; SCHOEFS, F. A comprehensive probabilistic model for chloride ingress in unsaturated concrete. Engineering Structures, v.51, p.259266, 2011.

BASTIDAS-ARTEAGA, E.; STEWART, M.G. Damage risks and economic assessment of climate adaptation strategies for design of new concrete structures subject to chloride-induced corrosion. Structural Safety, v.52, p.4053, 2015.

BATIS, G.; PANTAZOPOULOU, P.; TSIVILIS, S.; BADOGIANNIS, E. The effect of metakaolin on the corrosion behavior of cement mortars. Cement and Concrete Composites, v.27, p.125-130, 2005.

BECK, A.T.; GOMES, W. A comparison of deterministic, reliability-based and risk-based structural optimization under uncertainty. Probabilistic Engineering Mechanics, v.28, p.18-29, 2012.

BEER, G.; SMITH, I.M.; DUENSER, C. The Boundary Element Method with Programming: for Engineers and Scientists. Springer Wien New York, 494 p., 2008.

BELKHAYAT, A.P. Interval boundary element method for $2 \mathrm{D}$ transient diffusion problem using the directed interval arithmetic. Engineering Analysis with Boundary Elements, v.35, p.259-263, 2011.

BENTZ, D.P. CEMHYD3D: a three dimensional hydratation and microstructure development modelling package. National Institute of Standards and Technology. NISTIR, 2000a.

BENTZ, D.P. Influence of silica fume on diffusivity in cement-based materials: II. Multi-scale modeling of concrete diffusivity. Cement and Concrete Research, v.30, p.1121-1129, 2000.

BENTZ, D.P.; CLIFTON, J.R.; SNYDER, K.A. Predicting service life of chloride-exposed reinforced concrete. Concrete International, v.18, p.42-47, 1996.

BENTZ, D.P.; GARBOCZI, E.J.; LU, Y.; MARTYS, N.; SAKULICH, A.R.; WEISS, W.J. Modeling of the influence of transverse cracking on chloride penetration into concrete. Cement and Concrete Composites, v.38, p. 65-74, 2013. BERTOLINI, L.; ELSENER, B.; PEDEFERRI, P.; POLDER, R. Corrosion of Steel in Concrete: Prevention, Diagnosis, Repair. Wiley-VCH, Weinheim, 2000.

BIALECKI, R.; KHUN, G. Boundary element solution of heat conduction problems in multizone bodies of nonlinear materials. International Journal for Numerical Methods in Engineering, v.36, p.799-809, 1993. 
BIONDINI, F.; BONTEMPI, F.; FRANGOPOL, D.M.; MALERBA, P.G. Cellular automata approach to durability analysis of concrete structures in aggressive environments. Journal of Structural Engineering, v.130, n.11, p.1724$1737,2004$.

BIONDINI, F.; BONTEMPI, F.; FRANGOPOL, D.M.; MALERBA, P.G. Probabilistic Service Life Assessment and Maintenance Planning of Concrete Structures. Journal of Structural Engineering, v.132, n.5, p.810-825, 2006.

BIONDINI, F.; FRANGOPOL, D.; MALERBA, P.G. Uncertainty effects on lifetime structural performance of cable-stayed bridges. Probabilistic Engineering Mechanics, v.23, p.509-522, 2008.

BIOUBAKHSH, S. The penetration of chloride in concrete subject to wetting and drying: measurement and modelling. Doctoral thesis, UCL (University College London), 338 p., 2011.

BLESZYNSKI, R.; HOOTEN, R.; THOMAS, M.; ROGERS, C. Durability of ternary blend concrete with silica fume and blast-furnace slag: laboratory and outdoor exposure site studies. ACI Materials Journal, v.99, p.499-508, 2002.

BODDY A.; BENTZ, E.; THOMAS, M.D.A.; HOOTON, R.D. An overview and sensitivity study of a multimechanistic chloride transport model. Cement and Concrete Research, v.29, p.827-837, 1999.

BOHNI, H. Corrosion in Concrete Structures. CRC Press, New York, 2005.

BOKOTA, A.; ISKIERKA, S. An analysis of the diffusion-convection problem by the boundary element method. Engineering Analysis with Boundary Element, v.15, p.267-275, 1995.

BOLANDER, J.E.; SAITO, S. Fracture analyses using spring networks with random geometry. Engineering Fracture Mechanics, v.61, p.569-591, 1998.

BOUZOUBAA, N.; ZHANG, M.H.; MALHOTRA, V.M.; GOLDEN, D.M. Mechanical properties and durability of laboratory produced high-volume fly ash blended cements. ACI Special Publication, v.199, p.55-82, 2001.

BOYCE, W.E.; DIPRIMA, R.C. Equações Diferenciais Elementares e Problemas de Valor de Contorno. Ed. Guanabara Dois, Rio de Janeiro, 1979.

BREBBIA, C. A. The Boundary element method for engineers. London, Pentech Press, 1978a.

BREBBIA, C. A. Weighted residual classification of aproximate methods. Applied Mathematical Modelling, v.2, n.3, $1978^{\mathrm{b}}$.

BREBBIA, C.A.; DOMINGUEZ, J. Boundary Elements: An Introductory Course. WIT Press, 2 edition, 313 p., 1992.

BREBBIA, C.A.; SKERGET, P. Diffusion-advection problems using boundary elements. In: Adv. Finite Elements in Water Resources, Ed. Laible J.P., Brebbia C.A., Gray W., Pinder G., Springer, Berlin, Heidelberg, p.747-768, 1984. BREBBIA, C.A.; TELLES, J.C.F.; WROBEL, L.C. Boundary Element Techniques: Theory and Applications in Engineering. Springer-Verlag Berlin, Heidelberg, 464 p., 1984.

BREBBIA, C.A.; WALKER, S. Boundary element techniques in engineering. Newnes-Butterworths, London, 1980.

BREYSSE, D.; GERARD, B. Transport of fluids in cracked media, Penetration and permeability of concrete: Barriers to organic and contaminating liquids. RILEM Rep. 16, E\&FN Spon, London, p.123-153, 1997.

BRODING, W.C.; DIEDERICH, F.W.; PARKER, P.S. Structural optimization and design based on a reliability design criterion. Journal of Spacecraft and Rockets, v.1, n.1, p.56-61, 1964.

BROOMFIELD, J.P. Corrosion of Steel in Concrete. Taylor \& Francis, New York, 2007.

BROWE, R.D. Design and prediction of the life for reinforced concrete in marine and other chloride environments. Durability of building material, v.1, p. 113-125, 1982. 
BUENFELD, N.R.; GLASS, G.K.; HASSANEIN, A.M.; ZHANG, J.-Z. Chloride transport in concrete subjected to an electric field. Journal of Materials in Civil Engineering, v.10, p.220-228, 1998.

BUTTERFIELD, R.; TOMLIN, G.R. Integral techniques for solving zoned anisotropic continuum problems. In: Proc. Int. Conf. on Variational Methods in Engineering, v.2, C.A. Brebbia and H. Tottenham, eds., Southampton University Press, Southampton, 1972.

BYFORS, K. Chloride binding in cement paste. Nordic Concrete Research, v.5, p.27-38, 1986.

BYFORS, K. Influence of silica fume and flyash on chloride diffusion and $\mathrm{pH}$ values in cement paste. Cement and Concrete Research, v.17, p.115-130, 1987.

CAIRNS, J.; PLIZZARI, G.A.; DU, Y.; LAW, D.W.; FRANZONI, C. Mechanical properties of corrosion-damaged reinforcement. ACI Materials Journal, v.102, p.256-264, 2005.

CAO, J.; WANG, Y.; LI, K.; MA, Y. Modeling the Diffusion of Chloride Ion in Concrete Using Cellular Automaton. Journal of Materials in Civil Engineering, v.24, n.6, p. 783-788, 2012.

CASCUDO, O. O controle da corrosão de armaduras em concreto: inspeção e técnicas eletroquímicas. São Paulo: Pini; Goiania: Editora UFMG, 1997.

CASTEL, A.; FRANÇOIS, R.; ARLIGUIE, G. Mechanical behaviour of corroded reinforced concrete beams - Part 1: Experimental study of corroded beams. Materials and Structures, v.33, p.539-544, 2000a .

CASTEL, A.; FRANÇOIS, R.; ARLIGUIE, G. Mechanical behaviour of corroded reinforced concrete beams - Part

2: Bond and notch effects. Materials and Structures, v.33, p.545-551, $2000^{\mathrm{b}}$.

CERNÝ, R.; PAVLÍK, Z.; ROVNANÍKOVÁ, P. Experimental analysis of coupled water and chloride transport in cement mortar. Cement and Concrete Composites, v.26, p.705-715, 2004.

CHANG, Y.P.; KANG, C.S.; CHEN, D.J. The use of fundamental Green's functions for the solution of problems of heat conduction in anisotropic media. International Journal of Heat and Mass Transfer, v.16, p.1905-1918, 1973.

CHAPMAN, S.; COWLING, T.G. The Mathematical Theory of Non-uniform Gases: An Account of the Kinetic Theory of Viscosity, Thermal Conduction and Diffusion in Gases. Cambridge University Press, 3 ed., 423 p., 1970.

CHATZIGEORGIOU, G.; PICANDET, V.; KHELIDJ, A.; PIJAUDIER-CABOT, G. Coupling between progressive damage and permeability of concrete: Analysis with a discrete model. International Journal for Numerical and Analytical Methods in Geomechanics, v.29, p. 1005-1018, 2005.

CHAUDOUET, A. Three-dimensional transient thermo-elastic analyses by the BIE method. International Journal for Numerical Methods in Engineering, v.24, p. 25-45, 1987.

CHEN, E.; LEUNG, C.K. Finite element modeling of concrete cover cracking due to non-uniform steel corrosion, Engineering Fracture Mechanics, v.134, p.61-78, 2015.

CHEN, E.; LEUNG, C.K.Y. A coupled diffusion-mechanical model with boundary element method to predict concrete cover cracking due to steel corrosion. Corrosion Science, v.126, p.180-196, 2017.

CHENG, A.; HUANG, R.; WU, J.-K.; CHEN, C.-H. Influence of GGBS on durability and corrosion behavior of reinforced concrete. Materials Chemistry and Physics, v.93, p.404-411, 2005.

CHO, S.W.; CHIANG, S.C. Using the chloride migration rate to predict the chloride penetration resistance of concrete. In: Konsta-Gdoutos, M.S., editor. Measuring, monitoring and modeling concrete properties. Netherlands: Springer, p.575-581, 2006.

CHOE, D.E.; GARDONI, P.; ROSOWSKY, D.; HAUKAAS, T. Probabilistic capacity models and seismic fragility estimates for RC columns subject to corrosion. Reliability Engineering and System Safety, v.93(3), p.383-393, 2008.

CHRISTENSEN, R. M. Mechanics of composite materials. Wiley- Interscience, New York, 1979. 
CLEAR, K.C. Measuring rate of corrosion of steel in field concrete structures. TRR 1211, Transportation Research Board, National Research Council, Washington, D.C., p.28-37., 1992.

CLIMENT, M.A.; DE VERA, G.; LOPEZ, J.F.; GARCIA, C.; ANDRADE, C. Transport of chlorides through non saturated concrete after an initial limited chloride supply. In: Andrade, C., Kropp, J. (Eds.), Proceedings of the 2nd International Workshop on Testing and Modeling the Chloride Ingress into Concrete. RILEM Publications, Cachan, France, p.173-187, 2000.

COLLEPARDI, M. Quick method to determine free and bound chlorides in concrete. In: Proceedings of the $1 \mathrm{st}$ International RILEM Workshop on Microbial Impacts on Building Materials, p.10-16, Saint-Rémy-lès-Chevreuse, France, 1995.

COLLEPARDI, M.; MARCIALIS, A.; TURRIZIANI, R. La cinetica di penetrazione degli ioni cloruro nel calcestruzzo, Il Cemento, v.67, p.157-164, 1970.

COMITÉ EURO-INTERNATIONAL DU BÉTON. Durable concrete structures - design guide (CEB). Bulletin d'information, n.183, London, Thomas Telford., 1992.

COMITÊ EUROPEU DE NORMALIZAÇÃO. EN 1990: Eurocode - basis of structural design. Bruxelas, 90 p., 2002.

CORNELL, C.A. A Probability-Based Structural Code. Journal of the American Concrete Institute, v.66, p.974-985, 1969.

CORNELL, C.A.; JALAYER, F.; HAMBURGER, R.O.; FOUTCH, D.A. Probabilistic basis for 2000 SAC federal emergency management agency steel moment frame guidelines. Journal of Structural Engineering, v.128(4), p.526533, 2002.

CRANK, J. The mathematics of diffusion, 2 ed., Oxford (London): Clarendon Press, 414 p., 1975.

DANCKWERTS, P.V. Absorption by simultaneous diffusion and chemical reaction. Transactions of the Faraday Society, v.46, p.300-304, 1950.

DANG, V.H.; FRANÇOIS, R. Influence of long-term corrosion in chloride environment on mechanical behaviour of RC beam. Engineering Structures, v.48, p.558-568, 2013.

DARMAWAN M.S.; STEWART, M.G. Spatial variability of pitting corrosion and its effect on the reliability of prestressing wires. In: Der Kiureghain, A., Madanat, S., Pestana, J.M., editors. Nineth International Conference on Applications of Statistics and Probability in Civil Engineering, 1. Rotterdam: Millpress, p.541-548, 2003.

DAUVERGNE, P. Corrosion des armatures du béton. XI colloque CEFRACOR, 1982.

DAVEY, K.; HINDUJA, S. An improved procedure for solving transient heat conduction problems using boundary element method. International Journal for Numerical Methods in Engineering, v.28, p.2293-2306, 1989.

DEMIREL, V.; WANG, S. An efficient boundary element method for two-dimensional transient wave propagation problems. Applied Mathematical Modelling, v.11, p.411-416, 1987.

DESILVA, S.J; CHAN, L.C.; CHANDRA, A.; LIM, J. Boundary element method analysis for the transient conduction-convection in 2-D with spatially variable convective velocity. Applied Mathematical Modelling, v.22, p.81-112, 1998.

DHIR, R.K.; EL-MOHR, M.A.K.; DYER, T.D. Chloride binding in GGBS concrete. Cement and Concrete Research, v.26, p.1767-1773, 1996.

DHIR, R.K.; EL-MOHR, M.A.K.; DYER, T.D. Developing chloride resisting concrete using PFA. Cement and Concrete Research, v.11, p.1633-1639, 1997. 
DJERBI, A.; BONNET, S.; KHELIDJ, A.; BAROGHEL-BOUNY, V. Influence of traversing crack on chloride diffusion into concrete. Cement and Concrete Research, v.38, p.877-883, 2008.

DOMINICINI, W.K.; CALMON, J.L. Computational modeling for predicting corrosion initiation in reinforced concrete structures. Ibracon Structures and Materials Journal, v.10, n.6, p.1205-1244, 2017.

DOTTO, J.M.R.; DE ABREU, A.G.; DAL MOLIN, D.C.C.; MÜLLER, I.L. Influence of silica fume addition on concretes physical properties and on corrosion behaviour of reinforcement bars. Cement and Concrete Composites, v.26, p.31-39, 2004.

DU, X.L.; JIN, L.; ZHANG, R.B.; LI, Y. Effect of cracks on concrete diffusivity: a meso-scale numerical study. Ocean Engineering, v.108, p.539-551, 2015.

DU, Y.G.; CLARK, L.A.; CHAN, A.H.C. Effect of corrosion on ductility of reinforcing bars. Magazine of Concrete Research, v.57, n.7, p.407-419, 2005b.

DU, Y.G.; CLARK, L.A.; CHAN, A.H.C. Residual capacity of corroded reinforcing bars. Magazine of Concrete Research, v.57, n.3, p.135-147, 2005a.

DUPRAT, F. Reliability of RC beams under chloride-ingress. Construction and Building Materials, v.21, p.16051616, 2007.

DUVAL, R.; KADRI, E.H. Influence of silica fume on the workability and the compressive strength of highperformance concretes. Cement and Concrete Research, v.28, p.533-547, 1998.

EL HAMI A.; RADI B. Uncertainty and Optimization in structural mechanics, ISTE Ltd, UK, John Wiley \& Sons, USA, 2013.

EL HASSAN, J.; BRESSOLETTE, P.; CHATEAUNEUF, A.; EL TAWIL, K. Reliability based assessment of the effect of climatic conditions on the corrosion of RC structures subject to chloride ingress. Engineering Structures, v.32, p. 3279-3287, 2010.

EL MAADDAWY, T.A.; SOUDKI, K.A. Effectiveness of Impressed Current Technique to Simulate Corrosion of Steel Reinforcement in Concrete, ASCE Journal of Materials in Civil Engineering, v.15, p.41-47, 2003.

ELSENER B.; ANGST, U. Mechanism of electrochemical chloride removal. Corrosion Science, v.49, n.12, p.45044522, 2007.

ENGELBRECHT, J.P. Prefeitura finaliza obras de recuperação estrutural no Elevado do Joá. Prefeitura do Rio de Janeiro, 04 abr. 2014. Disponível em: <http://www.rio.rj.gov.br/web/guest/exibeconteudo?id=4674753>. Acesso em: 17 mar. 2018.

ENRIGHT, M.P.; FRANGOPOL, D.M. Condition prediction of deteriorating concrete bridges using Bayesian updating. Journal of Structural Engineering, v.125(10), p.1118-1125, 1999a.

ENRIGHT, M.P.; FRANGOPOL, D.M. Maintenance planning for deteriorating concrete bridges. Journal of Structural Engineering, v.125, n.12, p.1407-1414, 1999b.

ENRIGHT, M.P.; FRANGOPOL, D.M. Probabilistic analysis of resistance degradation of reinforced concrete bridge beams under corrosion. Engineering Structures, v.20, n.11, p.960-971, 1998a.

ENRIGHT, M.P.; FRANGOPOL, D.M. Service-life prediction of deteriorating concrete bridges. Journal of Structural Engineering, v.124, n.3, p.309-317, $1998^{\text {b. }}$

ERLIN, B.; VERBECK, G.J. Corrosion of metals in concrete-needed research. American Concrete Materials Journal, v.49, p.39-46, 1975. 
FARMANI, F.; BONAKDARPOUR, B.; RAMEZANIANPOUR, A.A. pH reduction through amendment of cement mortar with silica fume enhances its biological treatment using bacterial carbonate precipitation. Materials and Structures, v.48, p.3205-3215, 2015.

FELDMAN, R.; PRUDENCIO, L.R.; CHAN, G. Rapid chloride permeability test on blend cement and other concretes: correlations between charge, initial current and conductivity. Construction and Building Materials, v.13, p.149-154, 1999.

FIESSLER, B.; NEUMANN, H.-J; RACKWITZ, R. Quadratic Limit States in Structural Reliability. Journal of the Engineering Mechanics Division, v.105, p.661-675, 1979.

FOTIA, F. Crollo cavalcavia, esperto: la corrosione da sale la probabile causa. MeteoWeb, 29 out. 2016. Disponível em: $\quad$ <http://www.meteoweb.eu/2016/10/crollo-cavalcavia-esperto-la-corrosione-da-sale-la-probabilecausa/775564/>. Acesso em: 17 mar. 2018.

FOX, R. Optimization Methods for Engineering Design. Reading: Addison-Wesley, 1973.

FRANÇOIS, R.; MASO, J.C. Effect Of Damage In Reinforced Concrete On Carbonation Or Chloride Penetration. Cement and Concrete Research, v.18, p.961-970, 1988.

FRANKLIN, A. The Role of Experiments in the Natural Sciences: Examples from Physics and Biology. In: General Philosophy of Science. Focal Issues, Ed. Theo A.F. Kuipers, Elsevier, p.219-274, 2007.

FREUDENTHAL, A.M. The safety of structures. Transactions of ASCE, v.112, p.125-180, 1947.

FRIER, C.; SØRENSEN, J.D. Stochastic simulation of chloride ingress into reinforced concrete structures by means of multi-dimensional Gaussian random fields. In: Proceedings of the ninth international conference on structural safety and reliability, Rome, Italy: Rotterdam Millpress, 2005.

FU, C.; JIN, X.; YE, H.; JIN, N. Theoretical and experimental investigation of loading effects on chloride diffusion in saturated concrete. Journal of Advanced Concrete Technology, v.13, p.30-43, 2015.

GEBLER, S.H.; KLIEGER, P. Effect of fly ash on the durability of air-entrained concrete. In: Proceedings of the 2nd international conference on the use of fly ash, silica fume, slag, and other mineral by-products in concrete, April 21-25, Madrid, Spain. ACI Publication SP-91, 1986.

GÉRARD, B.; MARCHAND, J. Influence of cracking on the diffusion properties of cement-based materials, part I: Influence of continuous cracks on the steady-state regime. Cement and Concrete Research, v.30, p.37-43, 2000.

GEROSA, B. Ponte ad Annone, crollo del cavalcavia: Ecco i responsabili. Corriere Della Sera, 29 jun. 2017. Disponível em: <http://milano.corriere.it/notizie/cronaca/17_giugno_29/ponte-ad-annone-crollo-cavalcavia-eccoresponsabili-b3a14f9e-5c9f-11e7-95ac-44c3014ce0fa.shtml>. Acesso em: 17 mar. 2018.

GHOSH, J.; PADGETT, J.E. Aging considerations in the development of time-dependent seismic fragility curves. Journal of Structural Engineering, v.136(12), p.1497-1511, 2010.

GIPSON, G.S. Boundary element fundamentals-basic concepts and recent developments in poisson equation. Computational Mechanics Publications, Southampton, 1987.

GLASS G.K.; BUENFELD, N.R. The influence of chloride binding on the chloride induced corrosion risk in reinforced concrete. Corrosion Science, v.42, n.2, p.329-344, 2000.

GLASSER, F.P.; KINDNESS, A.; STRONACH, S.A. Stability and solubility relationships in AFm phases Part I. Chloride, sulfate and hydroxide. Cement and Concrete Research, v.29, p.861-866, 1999.

GONZALEZ, J.A.; ANDRADE, C.; ALONSO, C.; FELIU, S. Comparison of rates of general corrosion and maximum pitting penetration on concrete embedded steel reinforcement. Cement and Concrete Research, v.25, p.257-264, 1995. 
GOUDA, V.K. Corrosion and corrosion inhibition of reinforced steel. I. Immersed in alkaline solutions. British Corrosion Journal, v.5, p.198-203, 1970.

GOWRIPALAN, N.; SIRIVIVATNANON, V.; LIM, C.C. Chloride diffusivity of concrete cracked in flexure. Cement and Concrete Research, v.30, p.725-730, 2000.

GREENGARD, L.; STRAIN, J. A Fast Algorithm for the Evaluation of Heat Potentials. Communications and Pure and Applied Mathematics, v.43, p.949-963, 1990.

GRUBER, K.A.; RAMLOCHAN, T.; BODDY, A.; HOOTON, R., THOMAS, M. Increasing concrete durability with high-reactivity metakaolin. Cement and Concrete Composites, v.23, p.479-484, 2001.

GUO, L.; CHEN, T.; GAO, X.-W. Transient meshless boundary element method for prediction of chloride diffusion in concrete with time dependent non linear coefficients. Engineering Analysis with Boundary Elements, v.36, p.104-111, 2012.

GUO, S.; ZHANG, J.; LI, G.; ZHOU, F. Three-dimensional transient heat conduction analysis by Laplace transformation and multiple reciprocity boundary face method. Engineering Analysis with Boundary Elements, v.37, n.1, p.15-22, 2013.

GUOPING, L.; FANGJIAN, H.; YONGXIAN, W. Chloride ion penetration in stressed concrete. Journal of Materials in Civil Engineering, v.23, p.1145-1153, 2011.

GUZMÁN, S., GÁLVEZ, J.C., SANCHO, J.M. Cover cracking of reinforced concrete due to rebar corrosion induced by chloride penetration. Cement and Concrete Research, v.41, p.893-902, 2011.

GUZMAN, S.; GALVEZ, J.C.; SANCHO, J.M. Modelling of chloride ingress into concrete through a single-ion approach, application to an idealized surface crack pattern. International Journal for Numerical and Analytical Methods in Geomechanics, v.38, p.1683-1706, 2014.

HADJ-SADOK, A.; KENAI, S.; COURARD, L.; DARIMONT, A. Microstructure and durability of mortars modified with medium active blast furnace slag. Construction and Building Materials, v.25, p.1018-1025, 2011.

HAN, S.-H. Influence of diffusion coefficient on chloride ion penetration of concrete structure. Construction and Building Materials, v.21, n.2, p.370-378, 2007.

HASOFER, A.M.; LIND, N.C. Exact and Invariant Second Moment Code Format. Journal of Engineering Mechanics, v.100(1), p.111-121, 1974.

HE, X.; SHI, X. Chloride permeability and microstructure of Portland cement mortars incorporating nanomaterials. Transportation Research Record: Journal of the Transportation Research Board, v.2070, p.13-21, 2008.

HEDEGAARD, B.E.; HANSEN, T.C. Water permeability of fly ash concretes. Materials and Structures, v.25, p.381-387, 1992.

HOLDEN, W.R.; PAGE, C.L.; SHORT, N.R. Corrosion of reinforcement in concrete construction. In: Crane A.P., editor, Chichester: Ellis Horwood Ltd., p.143-150, 1983.

HOLICKÝ, M.; MATERNA, A.; SEDLACEK, G.; ARTEAGA, A.; SANPAOLESI, L.; VROUWENVELDER, T.; KOVSE, I.; GULVANESSIAN, H. Implementation of Eurocodes - Handbook 2 - Reliability Backgrounds.: Leonardo da Vinci Pilot Project CZ/02/B/F/PP-134007. Prague, 254 p., 2005

HOLLAND, R.B; KURTIS, K.E.; KAHN, L.F. Effect of different concrete materials on the corrosion of the embedded reinforcing steel. In: POURSAEE, A. Corrosion of Steel in Concrete Structures. Woodhead publishing, 1 ed., cap.7, p.131-147, 2016.

HOSSAIN, A.B.; FONSEKA, A.; BULLOCK, H. Early age stress development, relaxation, and cracking in restrained low W/B ultrafine fly ash mortars. Journal of Advanced Concrete Technology, v.6, n.2, p.261-271, 2008. 
HUSAIN, A.; AL-BAHAR, S.; SALAM, S.A.; AL-SHAMALI, O. Accelerated AC impedance testing for prequalification of marine construction materials. Desalination, v.165, p.377-384, 2004.

IBAÑEZ, M.T.; POWER, H. An efficient direct BEM numerical scheme for heat transfer problems using Fourier series. International Journal of Numerical Methods for Heat \& Fluid Flow, v.10, p.687-720, 2000.

INGBER, M.S.; MITRA, A.K. Solution of the transient heat conduction problem in zoned-homogeneous media by the boundary element method. In: Numerical Methods in Thermal Problems, vol. V, Ed. Lewis, R.W., Morgan, K. and Habashi, W.G, Pineridge Press, Swansea, 1987.

ITAGAKI, M. Boundary Element Methods Applied to Two-Dimensional Neutron Diffusion Problems. Journal of Nuclear Science and Technology, v.22(6), p.565-583, 1985.

IZQUIERDO, D.; ALONSO, C.; ANDRADE, C.; \& CASTELLOTE, M. Potentiostatic determination of chloride threshold values for rebar depassivation: Experimental and statistical study. Electrochimica Acta, v.49(17-18), p.2731-2739, 2004.

JANG, S.Y.; KIM, B.S; OH, B.H. Effect of crack width on chloride diffusion coefficients of concrete by steady-state migration tests. Cement and Concrete Research, v.41, p.9-19, 2011.

JIN, W.L.; YAN, Y.D.; WANG, H.L. Chloride diffusion in the cracked concrete. In: Fracture Mechanics of Concrete and Concrete Structures-Assessment, Durability, Monitoring and Retrofitting of Concrete Structures, Oh B.H., Choi O.C. and Chung L. (eds). Korea Concrete Institute, Seoul, Korea, p.880-886, 2010.

JOINT COMMITTEE ON STRUCTURAL SAFETY. JCSS Probabilistic model code. Denmark, 179 p., 2001. Disponível em: <http://www.jcss.ethz.ch/>. Acesso em: 15 jan. 2019.

KASSAB, A.J.; DIVO, E. A generalized boundary integral equation for isotropic heat conduction with spatially varying thermal conductivity. Engineering Analysis with Boundary Elements, v.18, p.273-286, 1996.

KASSIR, M.K.; GHOSN, M. Chloride-induced corrosion of reinforced concrete bridge decks. Cement and Concrete Research, v.32, p.139-143, 2002.

KATO, E.; KATO, Y.; UOMOTO, T. Development of simulation model of chloride transportation in cracked concrete. Journal of Advanced Concrete Technology, v.3, p.85-94, 2005.

KATSIKADELIS, J.T. Boundary Elements: theory and applications. Elsevier, 1 edition, 336 p., 2002.

KAYYALI, O.A.; HAQUE, M.N. The Cl:OH ratio in chloride-contaminated concrete - a most important criterion. Magazine of Concrete Research, v.47, p.235-242, 1995.

KHAN, M.U. Experimental investigation and numericalmodeling of two-dimensional chloride diffusion in concrete. M.S. thesis, King Fahd University of Petroleum and Minerals, Dhahran, Saudi Arabia, 2013.

KHATIB, J.M.; HIBBERT, J.J. Selected engineering properties of concrete incorporating slag and metakaolin. Construction and Building Materials, v.19, p.460-472, 2005.

KROPP J. Chlorides in concrete. In: Performance criteria for concrete durability. RILEM report 12: E\&FN SPON, p.138-164, 1995.

KUMAR, R.; GARDONI, P.; SANCHEZ-SILVA, M. Effect of cumulative seismic damage and corrosion on the life-cycle cost of reinforced concrete bridges. Earthquake Engineering and Structural Dynamics, v.38(7), p.887-905, 2009.

KURTIS, K.E.; MEHTA, P.K. A critical review of deterioration of concrete due to corrosion of reinforcing steel. ACI Special Publication, v.170, p.535-554, 1997. 
KURUMATANI, M.; ANZO, H.; KOBAYASHI, K.; OKAZAKI, S.; HIROSE, S. Damage model for simulating chloride concentration in reinforced concrete with internal cracks. Cement and Concrete Composites, v.84, p.62-73, 2017.

LACHAT, L.C.; COMBESCURE, A. Laplace transforms and boundary integral equation: application to transient heat conduction. First International Symposium on Innovative Numerical Analysis in Applied Engineering Sciences, CETIM, Versailles, France, 1977.

LARSEN, C.K. Chloride binding in concrete. Doctoral thesis, report no. 1998: 101, Norwegian University of Science and Technology, NTNU, 1998.

LEE, H.-S.; NOGUCHI, T.; TOMOSAWA, F. Evaluation of the bond properties between concrete and reinforcement as a function of the degree of reinforcement corrosion. Cement and Concrete Research, v.32, p.13131318, 2002.

LI, L.Y.; XIA, J.; LIN, S.S. A multi-phase model for predicting the effective diffusion coefficient of chlorides in concrete. Construction and Building Materials, v.26, n.1, p.295-301, 2012.

LIANG, M.-T.; HUANG, R.; JHENG, H.-Y. Revisited to the relationship between the free and total chloride diffusivity in concrete. Journal of Marine Science and Technology, v.18, n.3, p.442-448, 2010.

LIANG. J.; MOURELATOS, Z.P.; NIKOLAIDIS, E. A single-loop approach for system reliability-based design optimization, Journal of Mechanical Design, v.129, p.1215-1224, 2007.

LIANG. J.; MOURELATOS, Z.P.; TU, J. A single-loop method for reliability-based design optimization. In: Proceedings of DETC'04 ASME Design Engineering Technical Conferences and Computers and Information in Engineering Conference, paper C2004/DAC-57255, 2004.

LIM, C.C.; GOWRIPALAN, N.; SIRIVIVATNANON, V. Microcracking and chloride ion diffusion of concrete under sustained uniaxial compression. ACI Special Publication 221, American Concrete Institute, Farmington Hills, MI, p.893-910, 2004.

LIU, T.; WEYERS, R.W. Modeling The Dynamic Corrosion Process In Chloride Contaminated Concrete Structures. Cement and Concrete Research, v.28, n.3, 365-379, 1998.

LIU, Y. Fast Multipole Boundary Element Method: Theory and Applications in Engineering. Cambridge Press, 235 p., 2009.

LOEFFLER, C.F.; COSTALONGA, F. Formulação hipersingular do método dos elementos de contorno aplicada em problemas difusivo-advectivos. In: X SIMMEC - Simpósio de Mecânica Computacional Belo Horizonte - MG, Brasil, 2012.

LOEFFLER, C.F.; MANSUR, M.J. Dual reciprocity boundary element formulation for potential problems in infinite domains. In: Boundary Elements X, Ed. Brebbia, C.A., Springer-Verlag, Berlin, 1988.

LU, X.; LI, C.; ZHANG, H.; Relationship between the free and total chloride diffusivity in concrete. Cement and Concrete Research, v.32, p.323-326, 2002.

LUENBERGER, D. Linear and Nonlinear Programming. 2 ed., Reading: Addison-Wesley, 1984.

LUO, R.; CAI, Y.; WANG, C.; HUANG, X. Study of chloride binding and diffusion in GGBS concrete. Cement and Concrete Research, v.33, p.1-7, 2003.

LUPOI A.; FRANCHIN, P.; SCHOTAUNUS, M. Seismic risk evaluation of RC bridge structures. Earthquake Engineering and Structural Dynamics, v.32(8), p.1275-1290, 2003.

MAAGE, J.C.M; HELLAND, S.; CARLSEN, J.E. Practical non-steady state chloride transport as a part of a model for predicting the initiation period. In Proceedings of the 1st International RILEM Workshop, p.398-406, 1995. 
MAGALHÃES, L.E. Coppe recomenda reconstrução do Elevado do Joá. O Globo, 04 dez. 2012. Disponível em <https://oglobo.globo.com/rio/coppe-recomenda-reconstrucao-do-elevado-do-joa-6918698>. Acesso em: 17 mar. 2018.

MAHESWARAN, T.; SANJAYAN, J.G. A semi-closed-form solution for chloride diffusion in concrete with timevarying parameters. Magazine of Concrete Research, v.56, n.6, p.359-366, 2004.

MALHOTRA, V.M. Fly ash, slag, silica fume and rice-husk ash in concrete: a review. Concrete International, v.15, p.23-28, 1993.

MANGAT, P.S.; MOLLOY, B.T. Prediction of long term chloride concentration in concrete. Materials and Structures, v.27, p.338-346, 1994.

MARKESET, G. Critical chloride content and its influence on service life predictions. Materials and Corrosion, v.60, p.593-596, 2009.

MARTÍN-PÉREZ, B.; ZIBARA, H.; HOOTON, R.D.; THOMAS, M.D.A. A study of the effect of chloride binding on service life predictions. Cement and Concrete Research, v.30, p.1215-1223, 2000.

MARTÕ, B. A study of the effect of chloride binding on service life predictions. Cement and Concrete Research, v.30, n.8, p.1215-1223, 2000.

MARTYS, N.S.; TORQUATO, S.; BENTZ, D.P. Universal scaling of fluid permeability for sphere packings. Physical Review E, v.50, n.1, p.403-408, 1994.

MC2010. The FIB model code for concrete structures 2010, 2012. Retirado de <http://www.fibinternational.org/fib-model-code-2010>. Acesso em: 30 nov. 2018.

MCGEE, R. Modelling of durability performance of tasmanian bridges. In: Melchers RE, Stewart MG, editors. ICASP8 applications of statistics and probability in civil engineering, v.1, p.297-306, 1999.

MCGRATH; P.F. Development of test methods for predicting chloride penetration into high performance concrete. Ph.D. thesis, University of Toronto, 1996.

MEHRER, H.; STOLWIJK, N.A. Heroes and Highlights in the History of Diffusion. Diffusion Fundamentals, v.11, p.1-32, 2009.

MEHTA, P.K.; MONTEIRO, P.J.M. Concrete: Microstructure, properties, and materials. McGraw-Hill Professional, New York, 2005.

MEHTA, P.K.; MONTEIRO, P.J.M. Concreto: Microestrutura, propriedades e materiais. Tradução da 3. ed. em inglês. São Paulo: Ibracon, 2008.

MEIRA, G.R., ANDRADE, C., ALONSO, C., PADARATZ, I.J., BORBA JR., J.C. Salinity of marine aerosols in a Brazilian coastal area-Influence of wind regime. Atmospheric Environment, v.41, p.8431-8441, 2007.

MEIRA, G.R.; PINTO, W.T.A.; LIMA, E.E.P.; ANDRADE, C. Vertical distribution of marine aerosol salinity in a Brazilian coastal area - The influence of wind speed and the impact on chloride accumulation into concrete. Construction and Building Materials, v.135, p.287-296, 2017.

MEJLBRO, L. The complete solution of Fick's second laws of diffusion with time-dependent diffusion coefficient and surface concentration, Durability of concrete in saline environment. Cementa AB, Dandcryd Sweden, p.127-158, 1996.

MELCHERS, R.E. Structural reliability analysis and prediction. 2 ed., John Wiley and Sons, NY, 1999.

MIDGLEY, H.G.; ILLSTON, J.M. The penetration of chlorides into hardened cement pastes. Cement and Concrete Research, v.14, n.4, 1984.

MONTGOMERY, D.C.; RUNGER, G.C. Estatística aplicada e probabilidade para engenheiros, LTC Editora, 1999. 
MORI, Y.; ELLINGWOOD, B.R. Maintaining Reliability of Concrete Structures. I: Role of Inspection/Repair. Journal of Structural Engineering, v.120, n.3, p.824-845, 1994a.

MORI, Y.; ELLINGWOOD, B.R. Maintaining Reliability of Concrete Structures. II: Optimum Inspection/Repair, v.120, n.3, p.846-862, 1994b.

MORVAN, D. Application of the BEM to the resolution of an unsteady diffusion problem. BEM X, Computational Mechanics Publications, Southampton and Springer-Verlag, Berlin, 1988.

MU,S.; DE SCHUTTER, G.; MA, B.-G. Non-steady state chloride diffusion in concrete with different crack densities. Materials and Structures, v.46, p.123-133, 2013.

MUKHTAR, F.M.; AL-GADHIB, A.H. Numerical Simulation of Chloride Front Movement into Stressed Reinforced Concrete. In: Proceedings of the Thirteenth International Conference on Civil, Structural and Environmental Engineering Computing, B.H.V. Topping and Y. Tsompanakis, (Editors), Civil-Comp Press, Stirlingshire, Scotland, 2011.

MURTAGH, B.A.; SOUNDERS, M.A. MINOS 5.1 users guide: technical rep. SOL 83-20R. System Optimization Laboratory, Department of Operation Research, Stanford University, Stanford, Calif., 1987.

NACE $^{a}$ (National Association of Corrosion Engineers). Corrosion Failures: Lowe's Motor Speedway Bridge Collapse. Disponível em: <https://www.nace.org/CORROSION-FAILURES-Lowes-Motor-Speedway-BridgeCollapse.aspx>. Acesso em: 17 mar. 2018.

NACE $^{b}$ (National Association of Corrosion Engineers). Corrosion Failures: Leo Frigo Memorial Bridge Failure. Disponível em: <https://www.nace.org/Corrosion-Failure-Leo-Frigo-Memorial-Bridge-Failure.aspx>. Acesso em: 17 mar. 2018.

NAGAI, K.; SATO, Y.; UEDA, T. Mesoscopic simulation of failure of mortar and concrete by 2D RBSM. Journal of Advanced Concrete Technology, v.2, p.359-374, 2004.

NAGATAKI, S.; OTSUKI, N.; WEE, T.H.; NAKASHITA, K. Condensation of chloride ion in hardened cement matrix materials and on embedded steel bars. Materials Journal, v.90, p.323-332, 1993.

NEVILLE, M. Properties of Concrete. Pearson Education, 5 ed., 2011.

NGUYEN, T.H.; SONG, J.; PAULINO, G.H. Single-Loop system reliability-based design optimization using matrix-based system reliability method: Theory and applications. Journal of Mechanical Design, 132: 011005-1-11, 2010.

NILSSON, L.-O.; MASSAT, M.; TANG, L. Effect of Non-Linear Chloride Binding on the Prediction of Chloride Penetration Into Concrete Structures. ACI International Concrete, v.145, p.469-486, 1994.

NILSSON, L.-O.; POULSEN, E.; SANDBERG, P.; SØRENSEN, H.E.; KLINGHOFFER, O. HETEK, Chloride penetration into concrete, State-of-the-Art. Transport processes, corrosion initiation, test methods and prediction models. Report n.53, The Road Directorate, Copenhagen, 151 p., 1996.

NOCEDAL, J.; WRIGHT, S. Numerical Optimization, 2 ed., Springer, 2006.

NOKKEN, M.; BODDY, A.; HOOTON, R.D.; THOMAS, M.D.A. Time dependent diffusion in concrete-three laboratory studies. Cement and Concrete Research, v.36, n.1, p.200-207, 2006.

NOWAK, A.S.; COLLINS, K.R. Reliability of structures, Boston: McGraw-Hill, 2000.

OCHIAI, Y. Two-dimensional unsteady heat conduction analysis with heat generation by triple-reciprocity BEM. International Journal for Numerical Methods in Engineering, v.51, n.2, p.143-157, 2001.

OH, B.H.; YANG, S.Y.; SHIN, Y.S. Experimental investigation of the threshold chloride concentration for corrosion initiation in reinforced concrete structures. Magazine of Concrete Research, v.55, p.117-124, 2003. 
OTIENO, M.B.; BEUSHAUSEN, H.D.; ALEXANDER, M.G. Modelling corrosion propagation in reinforced concrete structures - A critical review. Cement \& Concrete Composites, v.33, n.2, p.240-245, 2010.

OZBOLT, J.; BALABANIC, G.; PERISKIC, G.; KUSTER, M. Modelling the effect of damage on transport processes in concrete. Construction and Building Materials, v.24, p.1638-1648, 2010.

PACHECO-TORGAL, F.; JALALI, S. Sulphuric acid resistance of plain, polymer modified, and fly ash cement concretes. Construction and Building Materials, v.23, p.3485-3491, 2009.

PACK, S.W.; JUNG, M.S.; SONG, H.W;, KIM, S.H.; ANN, K.Y. Prediction of time dependent chloride transport in concrete structures exposed to a marine environment. Cement and Concrete Research, v.40, p.302-312, 2010.

PAGE, C.L.; LAMBERT, P. Kinetics of oxygen diffusion in hardened cement pastes. Journal of Materials Science, v.22, p.942-946, 1987.

PAGE, C.L.; TREADAWAY, K.W.J. Aspects of the electrochemistry of steel in concrete. Nature, v.297, p.109-115, 1982.

PAGE, C.L.; VENNESLAND, Ø. Pore solution composition and chloride binding capacity of silica-fume cement pastes. Materials and Structures, v.16, p.19-25, 1983.

PAPADAKIS, V.G. Effect of supplementary cementing materials on concrete resistance against carbonation and chloride ingress. Cement and Concrete Research, v.30, p.291-299, 2000.

PAPADAKIS, V.G.; ROUMELIOTIS, A.P.; FARDIS, M.N.; VAGENAS, C.G. Mathematical modelling of chloride effect on concrete durability and protection measures. In: Dhir RK, Jones MR, editors. Concrete repair, rehabilitation and protection. London (UK): E\&FN Spon, p.165-174, 1996.

PAPOULIS, A. Probability, Random Variables and Stochastic Processes, Fourth edition, McGraw-Hill, Book Company, 2002.

PARANDE, A.K.; RAMESH BABU, B.; PANDI, K.; KARTHIKEYAN, M.S.; PALANISWAMY, N. Environmental effects on concrete using ordinary and pozzolana Portland cement. Construction and Building Materials, v.25, p.288-297, 2011.

PELLIZZER, G.P. Análise mecânica e probabilística da corrosão de armaduras de estruturas de concreto armado submetidas à penetração de cloretos. Dissertação, Escola de Engenharia de São Carlos, Universidade de São Paulo, 247 p., 2015.

PELLIZZER, G.P.; LEONEL, E.D.; NOGUEIRA, C.G. Numerical approach about the effect of the corrosion on the mechanical capacity of the reinforced concrete beams considering material nonlinear models. Ibracon Structures and Materials Journal, v.11, n.7, p.26-51, 2018.

PHILIBERT, J. One and a Half Century of Diffusion: Fick, Einstein, before and beyond. Diffusion Fundamentals, v.2, p.1-10., 2005.

PIJAUDIER-CABOT, G.; DUFOUR, F.; CHOINSKA, M. Permeability due to the increase of damage in concrete: From diffuse to localized damage distributions. Journal of Engineering Mechanics, v.135, p.1022-1028, 2009.

PINTO, P.E. Reliability methods in earthquake engineering. Progress in Structural Engineering and Materials, v.3(1), p.76-85, 2001.

POULSEN, E.; MEJLBRO, L. Diffusion of Chloride in Concrete: Theory and Apliccation. CRC Press, 1 ed., 480 p., 2006.

POURBAIX, A.; BERANGER, G.; CABRILLAC, C. Le coût de la corrosion. Evaluation et analyses des actions permettant de le réduire. XI colloque CEFRACOR, 1982. 
PREEZ, A.A.; ALEXANDER, M.G. A site study of durability indexes for concrete in marine conditions. Materials and Structures, v.37, p.146-154, 2004.

QI, L.; SEKI, H. Analytical study on crack generation situation and crack width due to reinforcing steel corrosion. Journal of Materials, Concrete Structures and Pavements, JSCE, 50, p.161-171 (in Japanese), 2001.

RACKWITZ, R.; FIESSLER, B. Structural Reliability Under Combined Load Sequences. Computers and Structures, v.9, p.489-494, 1978.

RAHMAN, M.; AL-KUTTI, W.; SHAZALI, M.; BALUCH, M. Simulation of chloride migration in compressioninduced damage in concrete. Journal Of Materials In Civil Engineering, v.24, p.789-796, 2012.

RAMEZANIANPOUR, A.A.; MALHOTRA, V.M. Effect of curing on the compressive strength, resistance to chloride-ion penetration and porosity of concretes incorporating slag, fly ash or silica fume. Cement and Concrete Composites, v.17, p.125-133, 1995.

RAO, S.S. Engineering Optimization: Theory and Practice. 4 ed., Wiley, 2009.

RASHKI, M.; MIRI, M.; MOGHADDAM, M.A. A new efficient simulation method to approximate the probability of failure and most probable point. Structural Safety, v.39, p.22-29, 2012.

RASHKI, M.; MIRI, M.; MOGHADDAM, M.A. A simulation-based method for reliability based design optimization problems with highly nonlinear constraints. Automation in Construction, v.47, p.24-36, 2014.

RIZZO, F.J.; SHIPPY, D.J. A method of solution for certain problems of transiente heat conduction. American Institute of Aeronautics and Astronautics Journal, v.8, n.11, 1970, p.2004-2009.

SAASSOUH, B.; LOUNIS, Z. Probabilistic modeling of chloride-induced corrosion in concrete structures using first- and second-order reliability methods. Cement and Concrete Composites, v.34, p.1082-1093, 2012.

SAETTA, A.V.; SCOTTA, R.V.; VITALIANI, R.V. Analysis of chloride diffusion into partially saturated concrete. ACI Materials Journal, v.90, p.441-451, 1993.

SAHMARAN, M. Effect of flexure induced transverse crack and selfhealing on chloride diffusivity of reinforced mortar. Journal of Materials Science, v.42, p.9131-9136., 2007.

SAMSON, E.; MARCHAND, J. Modeling the transport of ions in unsaturated cement-based materials. Computers and Structures, v.85, p.1740-1756, 2007.

SAMSON, E.; MARCHAND, J.; SNYDER, K.A. Calculation of ionic diffusion coefficients on the basis of migration test results. Mater Struct, v.36, p.156-165., 2003.

SARASWATHY, V.; SONG, H.-W. Corrosion performance of fly ash blended cement concrete: a state-of-art review. Corrosion Reviews, v.24, p.87-122, 2006.

SAVAS, B.Z. Effects of microstructure on durability of concrete. Raleigh, NC: North Carolina State University, 1999.

SAVIJA B.; LUKOVIC, M.; SCHLANGEN, E. Lattice modeling of rapid chloride migration in concrete. Cement and Concrete Research, v.61/62, p.49-63, 2014.

SCHIESSL, P.; BREIT, W. Local repair measures at concrete structures damaged by reinforcement corrosion aspects of durability. In: Proceedings of the 4th international symposium on corrosion of reinforcement in concrete construction, The Royal Society of Chemistry, Cambridge, p.525-34, 1996.

SELEEM, H.E.-D.H.; RASHAD, A.M.; EL-SABBAGHB, B.A. Durability and strength evaluation of highperformance concrete in marine structures. Construction and Building Materials, v.24, p.878-884, 2010.

SELVARAJ, R.; MURALIDHARAN, S.; SRINIVASAN, S. The influence of silica fume on the factors affecting the corrosion of reinforcement in concrete - a review. Structural Concrete FIB, v.4, p.19-24, 2003. 
SERGI, G.; YU, S.W.; PAGE, C.L. Diffusion of chloride and hydroxyl ions in cementitious materials exposed to a saline environment. Magazine of Concrete Research, v.44, p.63-69, 1992.

SHAO, W.; LI, J.. Service life prediction of cracked RC pipe piles exposed to marine environments. Construction and Building Materials, v.64, p.301-307, 2014.

SHAW, R.P. An integral equation approach to diffusion. International Journal of Heat and Mass Transfer, v.17, 693699, 1974.

SHEKARCHI, M.; BONAKDAR, A.; BAKHSHI, M.; MIRDAMADI, A.; MOBASHER, B. Transport properties in metakaolin blended concrete. Construction and Building Materials, v.24, p.2217-2223, 2010.

SHEWMON, P. Diffusion in Solids. 2 ed., Springer International Publishers, 2016, 246 p.

SHI, C.; STEGEMANN, J.A.; CALDWELL, R.J. Effect of supplementary cementing materials on the specific conductivity of pore solution and its implications on the rapid chloride permeability test (AASHTO T277 and ASTM C1202) results. ACI Materials Journal, v.95, p.389-394, 1998.

SHI, X.; LIU, Y.; MOONEY, M.; BERRY, M.; HUBBARD, B.; FAY, L.; LEONARD, A.B. Effect of chloride based deicers on reinforced concrete structures. Final report prepared for the Washington State Department of Transportation, 174 p., 2010.

SHI, X.; XIE, N.; FORTUNE, K.; GONG, J. Durability of steel reinforced concrete in chloride environments: An overview. Construction and Building Materials, v.30, p.125-138, 2012.

SIAMPHUKDEE, K.; COLLINS, F., ZOU, R. Sensitivity analysis of corrosion rate prediction models utilized for reinforced concrete affected by chloride. Journal of Materials Engineering and Performance, v.22(6), p.1530-1540, 2013.

SILLANPÄÄ, M. The Effect of Cracking on Chloride Diffusion in Concrete. Master's thesis, Aalto University, Aalto, Helsinki, Finland, 2010.

SIMON, J.; BRACCI, J.M.; GARDONI, P. Seismic response and fragility of deteriorated reinforced concrete bridges. Journal of Structural Engineering, v.136(10), p.1273-1281, 2010.

SINGH, K.M; TANAKA, M. On exponential variable transformation based boundary element formulation for advection-diffusion problems. Engineering Analysis with Boundary Elements, v.24, n.3, p.225-235, 2000.

SMITH, B.G. Durability of silica fume concrete exposed to chloride in hot climates. Journal of Materials in Civil Engineering, v.13, p.41-48, 2001.

SODA, M. Chloride diffusion analysis for cracked concrete by RBSM. Thesis (Master). Hokkaido University, 2006.

SODA, M.; UEDA, T. Chloride diffusion analysis for cracked concrete by RBSM. Proceedings of JCI, v.28, p.953958, 2006.

SONG, H.-W.; PACK, S.-W.; NAM, S.-H.; JANG, J.-C.; SARASWATHY, V. Estimation of the permeability of silica fume cement concrete. Construction and Building Materials, v.24, p.315-321, 2010.

SØRENSEN, H.E. Chloridtransport i haerdnet beton - mekanismer, modeller og malemetoder (Transport of chloride in hardened concrete - mechanisms, models and test methods). Ph.D thesis, 1996.

STANISH, K.; HOOTON, R.D.; THOMAS, M.D.A. A novel method for describing chloride ion transport due to an electrical gradient in concrete: Part 1. Theoretical description. Cement and Concrete Research, v.34, p.43-49, 2004.

STANISH, K.; THOMAS, M. The use of bulk diffusion tests to establish time-dependent concrete chloride diffusion coefficient. Cement and Concrete Research, v.33, p.55-62, 2003. 
STANISH, K.D.; HOOTON, R.D.; THOMAS, M.D.A. Testing the chloride penetration resistance of concrete: a literature review. FHWA contract DTFH61-97-R-00022, Canada: University of Toronto, 2000.

STEWART, M.G. Spatial variability of pitting corrosion and its influence on structural fragility and reliability of RC beams in flexure. Structural Safety, v.26, p.453-470, 2004.

STEWART, M.G.; ROSOWSKY, D.V. Structural safety and serviceability of concrete bridges subject to corrosion. Journal of Infrastructure Systems, v.4, n.4, p.146-155, 1998.

STEWART. M.G.; WANG, X.; NGUYEN, M.N. Climate change adaptation for corrosion control of concrete infrastructure. Structural Safety, v.35, p.29-39, 2012.

STRAIN, J. Fast potential theory II: Layer potentials and discrete sums. Journal of Computational Physics, v.99, p.251-270, 1992.

SUN, Y.-M.; LIANG, M.-T.; CHANG, T.-P. Time/depth dependent diffusion and chemical reaction model of chloride transportation in concrete. Applied Mathematical Modelling. Simulation and Computation for Engineering and Environmental Systems, v.36, n.3, p.1114-1122, 2012.

SUO, Q.; STEWART, M.G. Corrosion cracking prediction updating of deteriorating RC structures using inspection information. Reliability Engineering and System Safety, v.94, p.1340-1348, 2009.

SUTRADHAR, A.; PAULINO, G.H. The simple boundary element method for transient heat conduction in functionally graded materials. Computer Methods in Applied Mechanics and Engineering, v.193, p.4511-4539, 2004.

TAGUTI, Y. Método dos elementos de contorno na resolução do problema de segunda ordem em placas delgadas. Tese de doutorado em Engenharia Mecânica. Universidade Estadual Paulista, Guaratinguetá, 190 p., 2010.

TAIGBENU, A.; LIGGETT, J.A. An integral formulation applied to the diffusion and Boussinesq equations, International Journal for Numerical Methods in Engineering, v.23, p.1057-1079, 1986.

TANAKA, M.; KUROKAWA, K.; MATSUMOTO, T. A time-stepping DRBEM for transient heat conduction in anisotropic solids. Engineering Analysis with Boundary Elements, v.32, n.12, p.1046-1053, 2008.

TANG, L.; GULIKERS, J. On the mathematics of time-dependent chloride coefficient in concrete. Cement and Concrete Research, v.37, p.589-595, 2007.

TANG, L.; NILSSON, L.-O. Chloride binding capacity and binding isotherms of OPC pastes and mortars. Cement and Concrete Research, v.23, p.247-253, 1993.

TANG, L.; NILSSON, L.-O. Chloride diffusivity in high strength concrete at different ages. Nordic Concrete Research, v.11, p.162-171, 1992.

TAVARES, F. Coupled model of initiation and propagation of corrosion in reinforced concrete. Universidad Politécnica de Madrid, Tesis, 166 p., 2013.

THOFT-CHRISTENSEN, P. Assessment of the reliability profiles for concrete bridges. Engineering Structures, v.20, n.11, p.1004-1009, 1998.

THOMAS, M. Chloride threshold in marine concrete. Cement and Concrete Research, v.26, p.513-519, 1996.

THOMAS, M.; BAMFORTH, P. Modelling diffusion in concrete: Effect of fly ash and slag. Cement and Concrete Research, v.29, p.487-495, 1999.

THOMAS, M.D.A.; MATTHEWS, J.D. Performance of PFA concrete in a marine environment: 10-year results. Cement and Concrete Composites 26, p.5-20, 2004.

THOMAS, M.D.A.; SCOTT, A.; BREMNER, T.; BILODEAU, A.; DAY, D. Performance of slag concrete in marine environment. ACI Materials Journal, v.105, p.628-634, 2008. 
THOMAS, M.D.A.; SHEHATA, M.; SHASHIPRAKASH, S.; HOPKINS, D.; CAIL, K. Use of ternary cementitious systems containing silica fume and fly ash in concrete. Cement and Concrete Research, n.29, p.1207-1214, 1999.

TOMLIN, G.R. Numerical analysis of continuum problems in zoned anisotropic media. Ph.D. thesis, Southampton University, 1972.

TONGYAN, P.; LU, Y. Stochastic Modeling of Reinforced Concrete Cracking due to Nonuniform Corrosion: FEM-Based Cross-Scale Analysis. Journal of Materials in Civil Engineering, v.24, n.6, p.698-706, 2012.

TREJO, D.; HALMEN, C.; REINSCHMIDT, K. Corrosion Performance Tests For Reinforcing Steel In Concrete: Technical Report. Texas Transportation Institute, Report No. FHWA/TX-09/0-4825-1, 254 p., 2009.

TRITTHART, J. Chloride binding in cement II. The influence of the hydroxide concentration in the pore solution of hardened cement paste on chloride binding. Cement and Concrete Research, v.19, p.683-691, 1989.

TU, J.; CHOI, K.K.; PARK, Y.H. A new study on reliability-based design optimization. Journal of Mechanical Design, n.121 (4), p.557-564, 1999.

TUMIDAJSKI, P.J. Application of Danckwerts' solution to simultaneous diffusion and chemical reaction in concrete. Cement and Concrete Research, v.26, n.5, p.697-700, 1996.

TUUTTI, K. Chloride induced corrosion in marine concrete structures. In: Durability of concrete on saline environment, Uppsala, p.81-93, 1996.

TUUTTI, K. Corrosion of steel in concrete Swedish. Cement and concrete research institute Stockholm, 460 p., 1982.

VAL, D.V., CHERNIN, L., STEWART, M.G. Experimental and numerical investigation of corrosion-induced cover cracking in reinforced concrete structures. Journal of Structural Engineering, ASCE, v.135, p.376-385, 2009.

VAL, D.V.; MELCHERS, R.E. Reliability of deteriorating RC slab bridges. Journal of Structural Engineering (ASCE), v.123, n.12, p.1638-1644, 1997.

VAL, D.V.; STEWART, M.G. Life-cycle cost analysis of reinforced concrete structures in marine environments. Structural Safety, v.25, n.4, p.343-362, 2003.

VAL, D.V.; TRAPPER, P.A. Probabilistic evaluation of initiation time of chloride-induced corrosion. Reliability Engineering and System Safety, v.93, p.364-372, 2008.

VANDERPLAATS, G.N. Numerical Optimization Techniques for Engineering Design. 3 ed., Vanderplaats Research \& Development Inc., Colorado Springs, CO, 1999.

VIDAL, T.; CASTEL, A.; FRANÇOIS, R. Analyzing crack width to predict corrosion in reinforced concrete. Cement and Concrete Research, v.34, p.165-174, 2004.

VIDAL, T.; CASTEL, A.; FRANÇOIS, R. Corrosion process and structural performance of a 17 year old reinforced concrete beam stored in chloride environment. Cement and Concrete Research, v.37, p.1551-1561, 2007.

VU, K.A.T.; STEWART, M.G. Structural reliability of concrete bridges including improved chloride-induced corrosion models. Structural Safety, v.22, n.4, p.313-333, 2000.

WANG, B.; CHEN, X. Fast multipole accelerated dual reciprocity boundary element method for diffusion problems. Annals of Solid and Structural Mechanics, v.7, p.45-58, 2015.

WANG, H.; LU, C.; JIN, W.; BAI, Y. Effect of external loads on chloride transport in concrete. Journal of Materials in Civil Engineering, v.23, p.1043-1049, 2011.

WANG, L.; SODA, M.; UEDA, T. Simulation of Chloride Diffusivity for Cracked Concrete Based on RBSM and Truss Network Model. Journal of Advanced Concrete Technology, v.6, n.1, p.143-155, 2008. 
WANG, X.-Y.; ZHANG, L.-N. Simulation of Chloride Diffusion in Cracked Concrete with Different Crack Patterns. Advances in Materials Science and Engineering, 11 p., 2016.

WEE, T.H.; SURYAVANSHI, A.K.; TIN, S.S. Evaluation of rapid chloride permeability test (RCPT) results for concrete containing mineral admixtures. ACI Materials Journal, v.97, p.221-232, 2000.

WEYERS, R.E. Corrosion service life model. In: Silva-Araya W.P., de Rincon O.T., O’Neill L.P., editors. Repair and rehabilitation of reinforced concrete structures: the state of the art. Reston, VA: American Society of Civil Engineers, 105 p., 1998.

WEYERS, R.E.; PROWELL, B.D.; SPRINKEL, M.M.; VORSTER, M. Concrete bridge protection, repair, and rehabilitation relative to reinforcement corrosion: a methods application manual, SHRP-S-360, 268 p., 1993.

WHITING, D. Rapid Determination of the Chloride Permeability of Concrete. Report No. FHWA-RD-81-119, NTIS DB No. 82140724. Federal Highway Administration, Washington, DC, 174 p., 1981.

WHITING, D. Rapid measurement of the chloride permeability of concrete. Public Roads, v.45, p.101-112, 1982.

WHITING, D.A.; STEJSKAL, B.G.; NAGI, M.A. Condition of prestressed concrete bridge components: Technology review and field surveys. FHWA-RD-93-037, Federal Highway Administration, Washington, D.C., 1993.

WIENS, U.; SCHIESSL, P. Chloride binding of cement paste containing fly ash. In: Justnes H., editor. Proceedings of the 10th ICCC, Goteborg, Sweden, p.4-10, 1997.

WISNIAK, J. Thomas Graham. I. Contributions to thermodynamics, chemistry, and the occlusion of gases. Educación Química, v.24, p.316-325, 2013a.

WISNIAK, J. Thomas Graham. II. Contributions to diffusion of gases and liquids, colloids, dialysis, and osmosis. Educación Química, v.24, p.506-515, 2013².

WOLFRAM, S. Cellular automata and complexity - Collected papers. Addison-Wesley, Reading, Mass, 1994.

WONG, Y.L.; LAM, L.; POON, C.S.; ZHOU, F.P. Properties of fly ash-modified cement mortar-aggregate interfaces. Cement and Concrete Research, v.29, p.1905-1913, 1999.

WROBEL, L.C. On the use of time-dependent fundamental solutions for the boundary element formulation of diffusion problems. In: Boundary Elements X, Ed. Brebbia, C.A., Springer-Verlag, Berlin, 1988.

WROBEL, L.C. The Boundary Element Method Volume 1: Applications in Thermo-Fluids and Acoustics. John Wiley \& Sons, ltd., 451 p., 2002.

WROBEL, L.C.; BREBBIA, C.A. A formulation of the boundary element method for axisymmetric transient heat conduction. International Journal of Heat and Mass Transfer, v.24, p.843-850, 1981.

WROBEL, L.C.; BREBBIA, C.A. The boundary element for steady-state and transient heat conduction. In: Numerical Methods in Thermal Problems, R.W. Lewis and K. Morgan, eds., Pineridge Press, Swansea, Wales, 1979.

WROBEL, L.C.; BREBBIA, C.A. The dual reciprocity boundary element formulation for nonlinear diffusion problems. Computer Methods in Applied Mechanics and Engineering, v.65, p.147-164, 1987.

WROBEL, L.C.; BREBBIA, C.A.; NARDINI, D. The dual reciprocity boundary element formulation for transient heat conduction. In: Finite Elements in Water Resources, v.VI, Ed. Sa da Costa, A. et al., Springer-Verlag, Berlin, 1986.

XI, Y. BAZANT, Z.P. Modeling chloride penetration in saturated concrete. Journal Of Materials In Civil Engineering, v.11, n.1, p.58-65, 1999.

XIANG, T.; ZHAO, R. Reliability evaluation of chloride diffusion in fatigue damaged concrete. Engineering Structures, v.29, p.1539-1547, 2007. 
XING, F.; LEMG, F.G.; FENG, N.Q. The influence of long-term load on the chloride permeability in reinforced concrete. Proc. Int. Workshop Durability of Reinforced Concrete under Combined Mechanical and Climate Loads (CMCL), T. Zhao, F. H. Wittmann, and T. Ueda, eds., Adeificatio Publishers, Freiburg, Germany, p.139-147, 2005.

YANG, C.C.; WANG, L.C. The diffusion characteristic of concrete with mineral admixtures between salt ponding test and accelerated chloride migration test. Materials Chemistry and Physics, v.85, p.266-272, 2004.

YANG, L.F.; CHEN, Z.; GAO, Q.; JU, J.W. Compensation length of two-dimensional chloride diffusion in concrete using a boundary element model. Acta Mechanica, v.224, p.123-137, 2013.

YANG, Z.; SHI, X.; CREIGHTON, A.T.; PETERSON, M.M. Effect of styrene-butadiene rubber latex on the chloride permeability and microstructure of Portland cement mortars. Construction and Building Materials, v.23, p.2283-2290, 2009.

YOUN, B.D.; CHOI, K.K.; PARK, Y.H. Hybrid analysis method for reliability-based design optimization. Journal of Mechanical Design, n.125, p.221-32, 2003.

YOUNG, D.L.; TSAI, C.C.; MURUGESAN, K.; FAN, C.M.; CHEN C.W. Time dependent Fundamental Solutions for Homogeneous Diffusion Problems. Engineering Analysis with Boundary Elements, v.28, p.1463-1473, 2004.

YU, B.; YAO, W.; GAO, Q. A Precise Integration Boundary-Element Method for Solving Transient Heat Conduction Problems with Variable Thermal Conductivity. Journal of Numerical Heat Transfer, Part B: Fundamentals, An International Journal of Computation and Methodology, v.65, n.5, p.472-493, 2014.

YU, L.; FRANÇOIS, R.; DANG, V.H.; L'HOSTIS, V.; GAGNÉ, R. Development of chloride-induced corrosion in pre-cracked RC beams under sustained loading: Effect of load-induced cracks, concrete cover, and exposure conditions. Cement and Concrete Research, v.67, p.246-258, 2015.

YUAN, Y.; JI, Y.; SHAH, S.P. Comparison of Two Accelerated Corrosion Techniques for Concrete Structures. ACI Structural Journal, v.104, p.344-347, 2007.

YUN, S.Y.; HAMBURGER, R.O.; CORNELL, C.A.; FOUTCH, D.A. Seismic performance evaluation for steel moment frames. Journal of Structural Engineering, 128(4), p.534-545, 2002.

ZENG, Y. Modeling of chloride diffusion in hetero-structured concretes by finite element method. Cement and Concrete Composites, v.29, p.559-565, 2007.

ZHANG, J.; LOUNIS, Z. Nonlinear relationships between parameters of simplified diffusion-based model for service life design of concrete structures exposed to chlorides. Cement and Concrete Composites, v.31, p.591-600, 2009.

ZHANG, J.; LOUNIS, Z. Sensitivity analysis of simplified diffusion based corrosion initiation time model of concrete structures exposed to chlorides. Cement and Concrete Research, v.36, p.1312-1323, 2006.

ZHANG, R.; CASTEL, A.; FRANÇOIS, R. Concrete cover cracking with reinforcement corrosion of RC beam during chloride-induced corrosion process. Cement and Concrete Research, v.40, p.415-425, 2010.

ZHANG, R.; JIN, L.; LIU, M.; DU, X.-L.; LI, Y. Numerical investigation of chloride diffusivity in cracked concrete. Magazine of Concrete Research, v.69, p.850-864, 2017.

ZHANG, Y.; SUN, W.; CHEN, S.; GUO, F. Two and threedimensional chloride ingress into fly ash concrete. Journal Wuhan University of Technology, Materials Science Edition, v.26, n.5, p.978-982, 2011.

ZHOU, S. Analytical Model for Square Root Increase of Surface Chloride Concentration and Decrease of Chloride Diffusivity. Journal of Materials in Civil Engineering, v.28, p.04015181-1-04015181-7, 2016.

ZHU, W. Effect of corrosion on the mechanical properties of the corroded reinforcement and the residual structural performance of the corroded beams. Civil Engineering. INSA de Toulouse, 190 p., 2014. 
O delta de Dirac $\delta$ é um objeto matemático obtido a partir da diferenciação da função degrau unitário, também chamada de função de Heaviside, resultando igual a infinito em $x=0 \mathrm{e}$ nulo em todos os demais pontos, ou seja:

$\delta(x)= \begin{cases}0 & \text { se } x \neq 0 \\ \infty & \text { se } x=0\end{cases}$

O delta de Dirac pode ser interpretado como um retângulo infinitamente estreito e infinitamente alto, com área igual à unidade, de forma que $\int_{-\infty}^{\infty} \delta(x) d x=1$. O delta de Dirac é ilustrado na Figura (A.1).

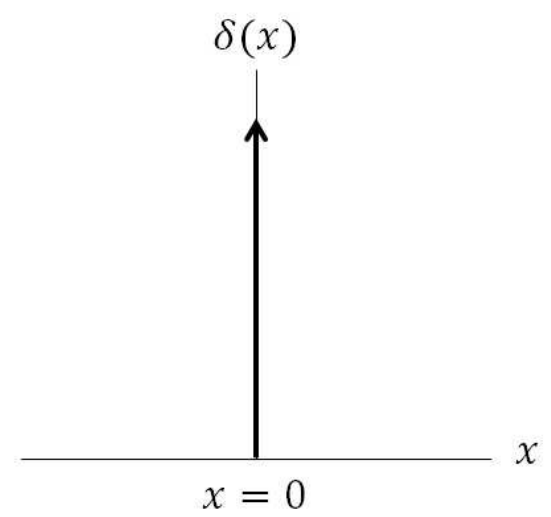

Figura A.1 - Ilustração do delta de Dirac

Seja $f(x)$ uma função conhecida e bem definida em $x=0$. Por meio do teorema da média para integrais é possível demonstrar que:

$\int_{-\infty}^{\infty} f(x) \delta(x) d x=f(0)$

A Equação (A.2) é normalmente denominada como uma propriedade de filtragem de $\delta(x)$ e ocorre devido ao fato de que a variação de $f(x)$ em torno do ponto $x=0$ ser desprezível. De forma geral é possível definir que:

$\int_{-\infty}^{\infty} f(x) \delta(x-a) d x=f(a)$

Para domínios planos, é possível definir o delta de Dirac da seguinte forma:

$$
\delta(x, y)= \begin{cases}0 & \text { se } x \neq y \\ \infty & \text { se } x=y\end{cases}
$$

De forma análoga, tem-se: 
$\int_{\Omega} f(y) \delta(x, y) d \Omega=\delta(x)$

Matematicamente, o delta de Dirac não pode ser definido como uma função, mas como um objeto matemático. Tal impossibilidade decorre do fato de que qualquer função que vale zero em todos os pontos exceto um, deve possuir integral nula em toda a reta, o que não ocorre com $\delta$, pois sua integral vale 1 (um) por definição. Desconsiderando o formalismo matemático, em termos práticos, $\delta$ pode ser interpretado como uma função na maioria dos casos. Ele pode ser utilizado para modelar ações pontuais como cargas concentradas em problemas da teoria da elasticidade ou mesmo impulsos na teoria cinemática da física. 


\section{ANEXO B: DELTA DE KRONECKER}

O delta de Kronecker $\Delta_{k i}$ é uma função de duas variáveis, usualmente inteiros não negativos. A função resulta igual a 1 (um) se as variáveis forem iguais e igual a 0 (zero) se forem diferentes, conforme:

$\Delta_{k i}= \begin{cases}0 & \text { se } k \neq i \\ 1 & \text { se } k=i\end{cases}$

O delta de Kronecker é utilizado em diversas áreas da matemática, física e engenharia, como forma de expressar compactamente sua definição. Em álgebra linear, a matriz identidade $I$ de ordem $n \times n$ possui cada um de seus valores iguais ao delta de Kronecker:

$I_{k i}=\Delta_{k i}$

Algumas das propriedades do delta de Kronecker são expressas por meio das seguintes equações:

$$
\begin{aligned}
& \sum_{i} \Delta_{k i} a_{i}=a_{k} \\
& \sum_{k} a_{k} \Delta_{k i}=a_{i} \\
& \sum_{j} \Delta_{i j} \Delta_{j k}=\Delta_{i k}
\end{aligned}
$$

